\title{
The renin-angiotensin system in obesity : metabolic and hemodynamic effects
}

Citation for published version (APA):

Goossens, G. H. (2006). The renin-angiotensin system in obesity : metabolic and hemodynamic effects. [Doctoral Thesis, Maastricht University]. Datawyse / Universitaire Pers Maastricht. https://doi.org/10.26481/dis.20060628gg

Document status and date:

Published: 01/01/2006

DOI:

10.26481/dis.20060628gg

Document Version:

Publisher's PDF, also known as Version of record

\section{Please check the document version of this publication:}

- A submitted manuscript is the version of the article upon submission and before peer-review. There can be important differences between the submitted version and the official published version of record.

People interested in the research are advised to contact the author for the final version of the publication, or visit the DOI to the publisher's website.

- The final author version and the galley proof are versions of the publication after peer review.

- The final published version features the final layout of the paper including the volume, issue and page numbers.

Link to publication

\footnotetext{
General rights rights.

- You may freely distribute the URL identifying the publication in the public portal. please follow below link for the End User Agreement:

www.umlib.nl/taverne-license

Take down policy

If you believe that this document breaches copyright please contact us at:

repository@maastrichtuniversity.nl

providing details and we will investigate your claim.
}

Copyright and moral rights for the publications made accessible in the public portal are retained by the authors and/or other copyright owners and it is a condition of accessing publications that users recognise and abide by the legal requirements associated with these

- Users may download and print one copy of any publication from the public portal for the purpose of private study or research.

- You may not further distribute the material or use it for any profit-making activity or commercial gain

If the publication is distributed under the terms of Article $25 \mathrm{fa}$ of the Dutch Copyright Act, indicated by the "Taverne" license above, 


\section{The renin-angiotensin system in obesity}

metabolic and hemodynamic effects 


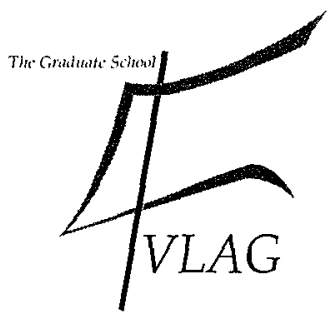

The studies presented in this thesis were performed within the Nutrition and Toxicology Research Institute Maastricht (NUTRIM), which participates in the Graduate School VLAG (Food Technology, Agrobiotechnology, Nutrition and Health Sciences), accredited by the Royal Netherlands Academy of Arts and Sciences.

Cover design: Gijs Goossens and De Wit Media Consultancy

Layout: Gijs Goossens

Printed by: Datawyse / Universitaire Pers Maastricht

(C) Gijs Goossens, 2006

ISBN-10: 905278-542-2

ISBN-13: 978-905278-542-4 


\section{The renin-angiotensin system in obesity}

\section{metabolic and hemodynamic effects}

\section{PROEFSCHRIFT}

ter verkrijging van de graad van doctor aan de Universiteit Maastricht

op gezag van de Rector Magnificus,

Prof. mr. G.P.M.F. Mols

volgens het besluit van het College van Decanen,

in het openbaar te verdedigen

op woensdag 28 juni 2006 om 14:00 uur

door

Gijsbertus Hendrikus Goossens

geboren te Boxtel op 23 juni 1979

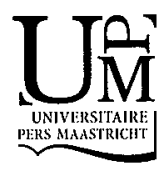




\section{Promotor}

Prof. dr. ir. W.H.M. Saris

\section{Co-promotores}

Dr. M.A. van Baak

Dr. E.E. Blaak

\section{Beoordelingscommissie}

Prof. dr. H.A.J. Struijker-Boudier (voorzitter)

Dr. M. Diamant (Vrije Universiteit, Amsterdam)

Prof. dr. M. Lafontan (Université Paul Sabatier, Toulouse, France)

Prof. dr. R.P. Mensink

Prof. dr. A.C. Nieuwenhuijzen Kruseman

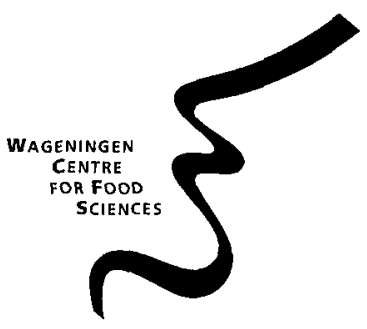

The research described in this thesis was partly supported by the Wageningen Centre for Food Sciences (WCFS).

Financial support by the Dutch Diabetes Research Foundation and the Netherlands Heart Foundation for the publication of this thesis is gratefully acknowledged. The author is also grateful to the Netherlands Association for the Study of Obesity (NASO) and WCFS for additional financial support. 


\section{Contents}

\section{Chapter 1}

General introduction

\section{Chapter 2}

Possible involvement of the adipose tissue renin-angiotensin system in the pathophysiology of obesity and obesity-related disorders

\section{Chapter 3}

Angiotensin II release from adipose tissue and the forearm in lean and obese subjects in vivo: effect of $\beta$-adrenergic stimulation

\section{Chapter 4}

Angiotensin II-induced effects on adipose and skeletal muscle tissue blood flow and lipolysis in normal-weight and obese subjects

\section{Chapter 5}

Angiotensin II: a major regulator of subcutaneous adipose tissue blood flow in humans

\section{Chapter 6}

Angiotensin II: a hormone that affects lipid metabolism in adipose tissue

\section{Chapter 7}

ACE inhibition and insulin sensitivity in obese insulin resistant subjects: a double-blind placebo-controlled tandomized trial to examine underlying mechanisms

\section{Chapter 8}

Management of obesity-related hypertension: reducing RAS activity

\section{Chapter 9}

General discussion

$\begin{array}{ll}\text { Summary - Samenvatting } & 171\end{array}$

Dankwoord 


$$
\text { - }
$$


General introduction 
Obesity is the result of an imbalance between energy intake and energy expenditure. When energy intake exceeds energy expenditure, the energy surplus is stored mainly in adipose tissue in the form of triacylglycerol (TAG). Whole-body energy balance therefore regulates the amount of TAG stored in adipocytes, which in turn reflects the net balance between fat deposition and fat mobilization.

According to the World Health Organization (WHO), overweight is defined as a body mass index (BMI) between $25-30 \mathrm{~kg} / \mathrm{m}^{2}$, and obesity is defined as a BMI of $30 \mathrm{~kg} / \mathrm{m}^{2}$ or greater (1). The prevalence of obesity is progressively increasing worldwide and has already reached epidemic proportions in several countries. Based on one of the national surveys from 1999-2000, the prevalence of obesity in the United States was 30.5\% (2) compared with 22.9\% in the period 1988-1994 (3). The same trend can be observed in The Netherlands. Between 1976 and 1997, the prevalence of obesity steadily increased from 4.9 to $8.5 \%$ in men and from 6.2 to $9.3 \%$ in women aged $37-43$ years (4). Recent data indicate that this trend, which was observed in each age-category, continued between 1998-2001, and showed that the prevalence of obesity was $10 \%$ in men and $12 \%$ in women aged $20-70$ years (5). Although genetic predisposition for obesity plays a role in its development, the dramatic increase in the prevalence of obesity in industrialized countries over the last few decades is most likely due to changes in environmental factors, such as changes in dietary intake (i.e. high-fat diet) and a substantial decrease in the amount of physical activity (6).

Obesity is a major contributor to the global burden of chronic diseases. Abdominal obesity plays a central role in the metabolic syndrome and is a major risk factor for chronic diseases, such as type 2 diabetes mellitus and cardiovascular disease (7). In fact, obesity is the most important risk factor for the development of type 2 diabetes (8), which is further stressed by the fact that obesity, body fat distribution and weight gain throughout adulthood are important predictors of diabetes $(8,9)$. Consequently, the prevalence of obesity-related disorders, such as type 2 diabetes mellitus and hypertension, is also increasing at an alarming rate. Although the relationship between obesity, hypertension and insulin resistance is well-recognized (10), the molecular mechanisms involved remain relatively poorly understood. Unravelling the underlying mechanisms of obesity and obesity-related disorders may increase the rationale for strategies to prevent or treat type 2 diabetes and cardiovascular disease.

This chapter will first describe the pathophysiological role of adipose tissue in obesity-related insulin resistance and hypertension. Thereafter, the focus will be on the functional importance of the renin-angiotensin system (RAS) in obesity-related 
disorders. Potential underlying autocrine, paracrine, and endocrine mechanisms that may explain the link between the RAS in adipose tissue, insulin resistance, and hypertension will be discussed. Finally, an overview of the studies described in this thesis will be provided.

\section{Adipose tissue: an important link between obesity, insulin resistance, and hypertension}

Adipose tissue excess plays a central role in the development of insulin resistance and hypertension. In this section it will be discussed how disturbances in adipose tissue fatty acid fluxes in obesity may be linked with insulin resistance. Furthermore, disturbances in skeletal muscle fatty acid handling that may underlie obesity-related insulin resistance are described. Finally, the endocrine function of adipose tissue is discussed in relation to insulin resistance and hypertension.

\section{Adipose tissue as lipid storage depot}

Adipose tissue is the main lipid storage depot in our body, and is of crucial importance in buffering the daily influx of dietary fat entering the circulation. The buffering capacity for lipid storage in adipose tissue is reduced when adipocyte differentiation is decreased. Furthermore, any event that increases the TAG content in a single adipocyte decreases the buffering capacity for further lipid storage. Therefore, inhibition of fat cell lipolysis and stimulation of lipogenesis may also contribute to a reduced buffering capacity in adipose tissue. In obesity, adipose tissue is overloaded with TAG and the buffering capacity for lipid storage in adipocytes is decreased, especially in the postprandial state. Therefore, other tissues are exposed to an excessive influx of TAG and fatty acids (11). A large number of observations suggest that accumulation of TAG in non-adipose tissues may play an important role in the development of insulin resistance in obesity. Insulin resistance is associated with increased TAG concentration in skeletal muscle (12-14), pancreatic islets (15) and the liver $(16,17)$. The importance of the buffering function of adipose tissue is further emphasized by the adverse metabolic consequences in situations where adipose tissue is lacking. A deficiency of adipose tissue, as in lipodystrophy, is also associated with insulin resistance and a high incidence of type 2 diabetes (18). Mice models that lack adipose tissue are severely insulin resistant and have an elevated TAG content in skeletal muscle and the liver (19). Surgical implantation of adipose tissue in these mice reduces TAG content in 


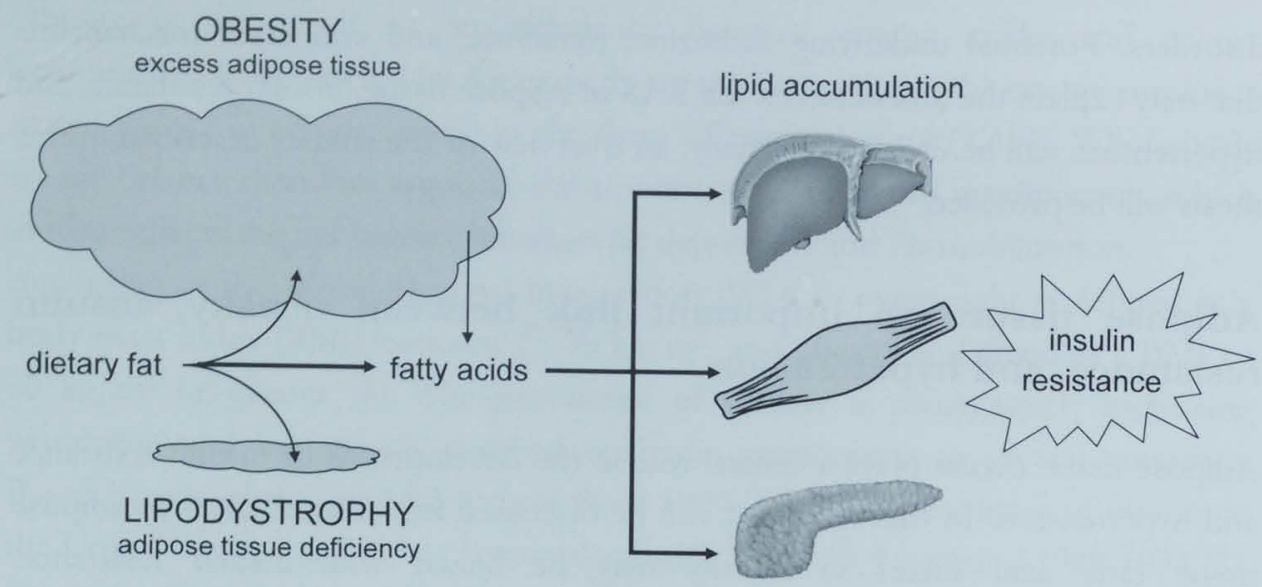

Figure 1.1 The normal function of adipose tissue is to buffer the daily influx of dietary fat. When the buffering capacity for lipid storage in adipose tissue is decreased, as in obesity (when the fat cells are overloaded) and lipodystrophy (when the adipose tissue necessary to perform such a function is lacking), other tissues are exposed to an excessive influx of fatty acids and TAG, which in turn may result in TAG storage that interferes with insulin sensitivity (skeletal muscle and liver) and insulin secretion (pancreas). Adapted from Frayn (11).

these tissues, and reverses the insulin resistance in a dose-dependent manner (20). This is completely in accordance with the view that the normal function of adipose tissue is to buffer the daily influx of dietary fat and indeed suggests that ectopic fat deposition is related to insulin resistance (figure 1.1).

Thus, a reduced buffering capacity for lipid storage in adipose tissue results in an increased flux of fatty acids and TAG to other organs. In addition to an increased storage of lipids in tissues such as skeletal muscle, liver, and pancreas, an increased delivery of fatty acids to the liver leads to a higher glucose production (21-23), an elevation of hepatic very low-density lipoprotein (VLDL)-TAG output (24), and a reduced clearance of insulin by the liver (25-27), resulting in conditions associated with insulin resistance, such as glucose intolerance, hyperlipidemia, and hyperinsulinemia, respectively (28) (figure 1.2). It is widely believed that accumulation of visceral fat is responsible for the relationship between obesity and insulin resistance. A common theory is that visceral obesity leads to an increased delivery of fatty acids to the liver, because only this fat depot has direct access to the liver via the portal vein. However, studies on the pathway of lipid deposition in the visceral compartment (29), together with several elegant kinetic studies in humans (30-32), cast doubt on the impact of excess visceral adipose tissue on 


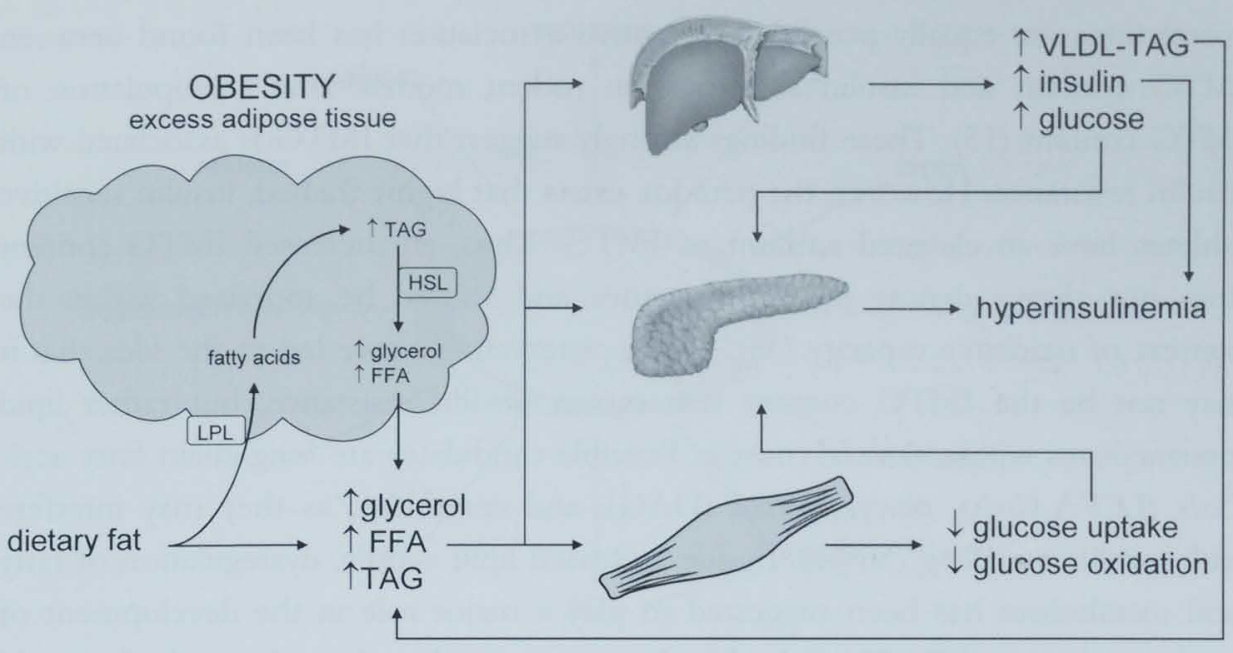

Figure 1.2 LPL and HSL act on circulating TAG-rich lipoprotein particles and stored TAG, respectively, to release fatty acids. The fatty acids that are released are transported into the circulation or are reesterified. A decreased buffering capacity for lipid storage in adipose tissue results in an increased flux of fatty acids and TAG to skeletal muscle, liver, and pancreas. In addition to lipid accumulation in these tissues, this leads to an increased liver glucose production, elevated hepatic VLDL-TAG output, and decreased insulin clearance by the liver. Together with disturbances in skeletal muscle glucose metabolism (decreased insulin-mediated glucose uptake and oxidation) these events result in conditions related to insulin resistance, such as glucose intolerance, hyperinsulinemia, and hyperlipidemia. LPL, lipoprotein lipase; HSL, hormone-sensitive lipase; TAG, triacylglycerol; FFA, free fatty acids; VLDL, very low-density lipoprotein.

peripheral insulin sensitivity. Studies that will elucidate the functional differences between different fat depots under both fasting and postprandial conditions may provide more insight into the importance of various adipose tissue depots in disturbances in glucose and lipid metabolism.

Skeletal muscle is one of the most important tissues in the development of insulin resistance, as it accounts for more than $80 \%$ of insulin-stimulated glucose disposal (33) and is the most important organ concerning the uptake and oxidation of fatty acids, especially during physical exercise and in the fasting state. An excessive lipid supply to skeletal muscle may, however, lead to lipid accumulation in this tissue. The depot of TAG in skeletal muscle, called intramuscular triacylglycerol (IMTG) content, is relatively small, but it seems to be metabolically important. Human studies have demonstrated that IMTG content is correlated with the severity of insulin resistance in obese subjects, even after adjusting for visceral adiposity (14, 34). Until now, it is not fully understood whether the accumulation of IMTG is a cause (primary event) or effect (secondary event) of insulin resistance. Although correlations cannot prove cause or effect and alternative interpretations of these 
correlations are equally possible, a negative association has been found between IMTG content and insulin sensitivity in rodent models after manipulation of IMTG content (15). These findings strongly suggest that IMTG is associated with insulin resistance. However, the paradox exists that highly trained, insulin sensitive athletes have an elevated amount of IMTG. Thus, an increased IMTG content does not always denote insulin resistance and should be appraised within the context of oxidative capacity (35). These observations have led to the idea that it may not be the IMTG content that causes insulin resistance, but rather lipid intermediates within skeletal muscle. Possible candidates are long-chain fatty acylCoA (LCFA-CoA), diacylglycerol (DAG), and ceramides, as they may interfere with insulin signalling (36-41). Beside increased lipid supply, dysregulation of fatty acid metabolism has been suggested to play a major role in the development of insulin resistance (42). There is abundant evidence that skeletal muscle fatty acid handling is disturbed in insulin resistant conditions, with decreased fat oxidation in the fasting state (43-48) and increased fat oxidation during insulin-stimulated conditions (44). These differences in fatty acid handling in skeletal muscle have led to the concept of metabolic inflexibility, which can be defined as a reduced capacity to switch between substrates. Especially the reduced fat oxidative capacity during fasting has been suggested to play a key role in the accumulation of lipids within skeletal muscle (35).

Without discussing into detail what could be the mechanisms for the diminished oxidative capacity of skeletal muscle in insulin resistance, it has been demonstrated that the transport of fatty acids into the mitochondria may be impaired. There is evidence for a decreased activity of carnitinepalmitoyltransferase-1 (CPT-1), which is the rate-limiting step of the transport of fatty acids into the mitochondria and, therefore, a key regulator of fatty acid oxidation, in obesity and insulin resistance (42, 49). Furthermore, recent evidence suggests that reduced mitochondrial content and/or function plays an important role in the reduced oxidative capacity in the insulin resistant muscle in type 2 diabetes and obesity (50-54).

In summary, disturbances in adipose tissue fatty acid fluxes in obesity lead to an excess supply of TAG and fatty acids to other organs, such as the liver, pancreas, and skeletal muscle, resulting in insulin resistance.

\section{Adipose tissue as endocrine organ}

Until recently, adipose tissue was seen as a passive organ for energy storage. Siiteri (55) was the first who suggested about twenty years ago that adipose tissue has an 


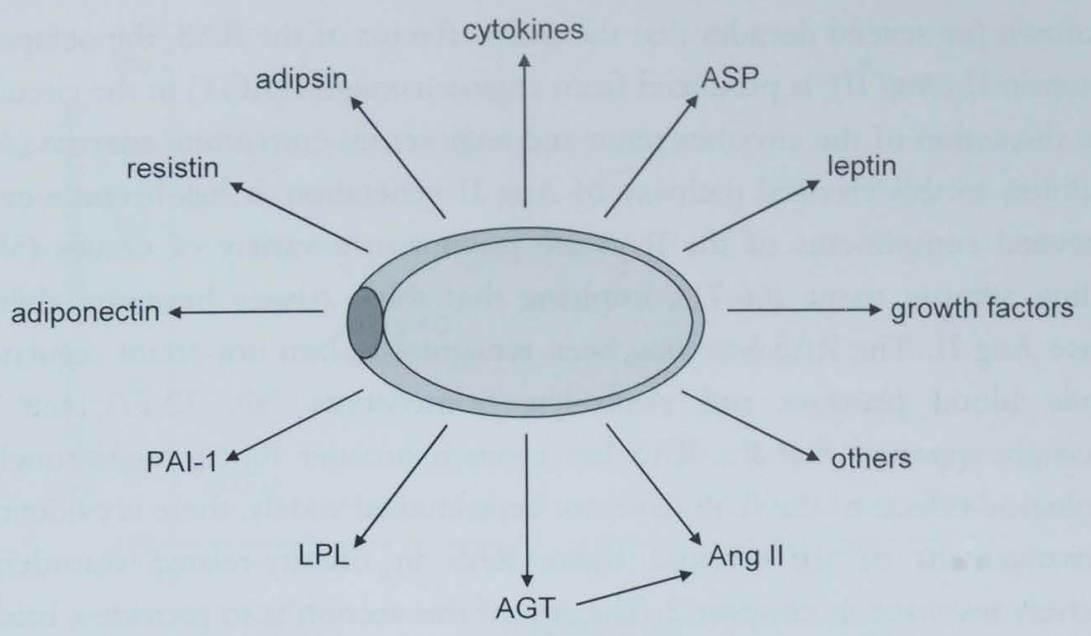

Figure 1.3 Adipocytes express and secrete a variety of substances, which may exert important autocrine/paracrine and endocrine functions. Some of these factors may play a role in the metabolic and hemodynamic disturbances observed in obesity and insulin resistance.

endocrine function. Research of the past decade has shown the complex nature of adipose tissue and demonstrated that the traditional view of adipose tissue is no longer valid. Adipocytes are now known to express and secrete a variety of substances, which may act at both the local (autocrine and/or paracrine) and systemic (endocrine) level. These factors include cytokines, growth factors, adiponectin, resistin, adipsin, leptin, acylation stimulating protein (ASP), plasminogen activator inhibitor-1 (PAI-1), lipoprotein lipase (LPL), and components of the renin-angiotensin system (RAS) (figure 1.3) $(56,57)$. Thus, in addition to the ability of adipose tissue to modulate its own metabolic activities, adipocytes signal to other tissues to regulate their metabolism. On the other hand, adipose tissue expresses numerous receptors that allow it to respond to several afferent signals, such as hormones and the central nervous system. Through this interactive network, adipose tissue is involved in the regulation of a variety of biological processes. Since the recognition of adipose tissue as an endocrine organ, there has been great interest in the possibility that an adipose tissue-derived factor may contribute to the metabolic and hemodynamic disturbances seen in obesity and insulin resistance. Several of these so-called adipokines influence insulin sensitivity and glucose metabolism profoundly, and they might provide a molecular link between obesity and obesity-related hypertension and insulin resistance. 
It is known for several decades that the main effector of the RAS, the octapeptide angiotensin II (Ang II), is produced from angiotensinogen (AGT) in the circulation due to the action of the enzymes renin and angiotensin-converting enzyme (ACE). In addition to this classical pathway of Ang II generation, it has become evident that several components of the RAS are present in a variety of tissues (58-65), including adipose tissue (66-71), implying that these tissues have the ability to produce Ang II. The RAS has long been recognized as an important regulator of systemic blood pressure and electrolyte homeostasis $(59,72-77)$, but it is increasingly apparent that the RAS has a much broader function. Although the physiological effects of the RAS have not been studied widely, there is evidence for the involvement of the adipose tissue RAS in obesity-related disorders, as extensively reviewed in chapter 2 . The aim of this section is to provide a brief upto-date overview of potential underlying autocrine, paracrine, and endocrine effects of the RAS that may explain the link between obesity, hypertension, and insulin resistance.

\section{RAS activity and obesity}

Circulating RAS components are increased in obesity (78-84), and it has recently been demonstrated that weight loss reduces systemic RAS activity in humans (78). These observations suggest that RAS components that are expressed in adipose tissue $(66,67,69,78)$ may also be secreted into the circulation. Thus, it is tempting to speculate that the adipose tissue RAS may exert both autocrine/patacrine and endocrine effects. Increased systemic RAS activity in obesity could have pathophysiological effects that may contribute to metabolic and hemodynamic disturbances, as will be discussed later in this chapter.

Obesity is frequently accompanied by hypertension, but the mechanisms by which an excess fat mass may lead to hypertension are not fully understood. The RAS has been established as a major determinant of blood pressure and cardiovascular disease $(75,85,86)$, and some observations suggest that the RAS in adipose tissue could be an important link between obesity and hypertension. The concept that adipose tissue contributes to increased systemic RAS activity is supported by a study where wild-type (WT) mice were compared with AGT knock-out mice $\left(\mathrm{AGT}^{*} /\right.$ ), and with transgenic mice specifically expressing AGT mRNA in adipose tissue either on the AGT $\%$ background $(\mathrm{Tg}-\mathrm{KO})$ or on the WT background (TgWT) (87). Plasma AGT was undetectable in $A G T \%$ mice, whereas plasma AGT 


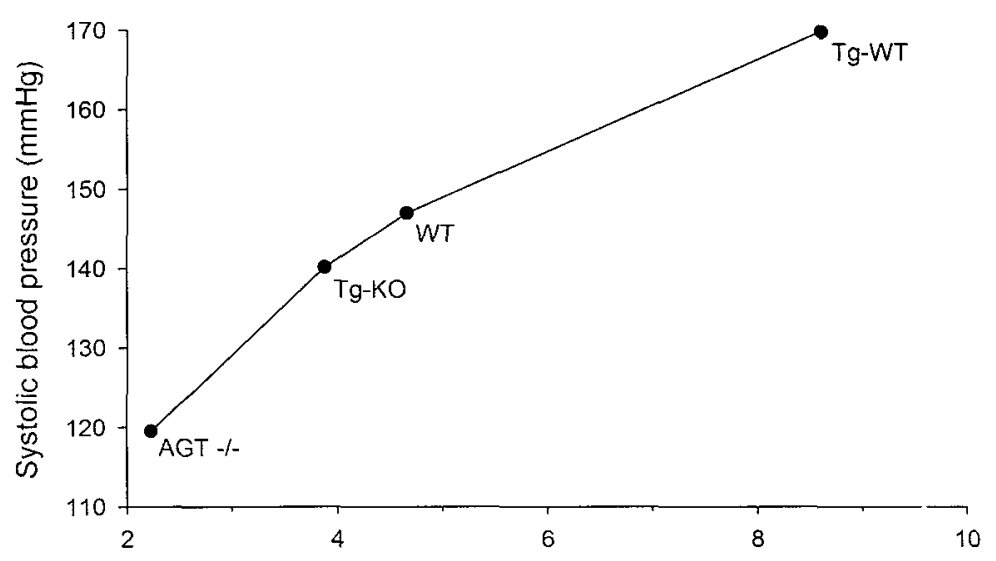

Fat mass $(\mathrm{g})$

Figure 1.4 Systolic blood pressure as a function of fat mass in 16- to 20 -week-old wild-type (WT) mice, AGT knock-out mice (AGT $\%$ ), and transgenic mice specifically expressing AGT mRNA in adipose tissue either on the $A G T \%$ background $(\mathrm{Tg}-\mathrm{KO})$ or on the WT background (Tg-WT). Plasma AGT was undetectable in AGT $\%$ mice, whereas plasma AGT concentrations in $\mathrm{Tg}-\mathrm{KO}$ were $20-30 \%$ of those in WT mice. In Tg-WT mice, plasma AGT concentrations increased by $40 \%$ compared with WT mice. These data indicate that adipocytes are a considerable source of plasma $A G T$, and suggest that adipose tissuc-derived AGT plays a role in elcvating blood pressure. $A G T$, angiotensinogen. Adapted from Massiera et al. (87).

concentrations in $\mathrm{Tg}-\mathrm{KO}$ were $20-30 \%$ of those observed in WT mice. Moreover, plasma AGT concentrations increased by $40 \%$ in Tg-WT compared with WT mice, indicating that adipocytes are a considerable source of plasma AGT. Interestingly, the transgenic mice had an elevated blood pressure compared with their knock-out controls (87), supporting an important role for adipose tissuederived AGT in obesity-related hypertension (figure 1.4). In addition, AGT $\%$ mice showed a lower diet-induced weight gain compared with WT mice. In line with this, $\mathrm{Tg}-\mathrm{KO}$ and $\mathrm{Tg}$-WT increased body weight and fat mass compared with the non-transgenic mice. This may be explained by increased Ang II production in the adipose tissue of the transgenic mice, as direct lipogenic effects of Ang II have been reported in vitro (88). These findings suggest that a high AGT expression in adipose tissue may result in a positive feedback loop in these animals, whereby adipose tissue enlargement is achieved by AGT production and local Ang II formation, which in turn may further increase AGT production and secretion, and elevate blood pressure. It has been demonstrated recently that $5 \%$ weight loss decreased systemic RAS activity, blood pressure, and AGT mRNA expression in adipose tissue in obese subjects (78), suggesting that increased RAS activity is a 
consequence of obesity, rather than a primaty factor in the development of obesity in humans.

Taken together, evidence suggests that components of the RAS are produced and secreted from adipose tissue into the circulation. Adipose tissue-derived RAS components may be important determinants of blood pressure in obese subjects with hypertension. However, direct evidence for this in vivo in humans is still lacking.

\section{RAS and type 2 diabetes mellitus}

Recent clinical trials have suggested that blockade of the RAS, either by ACE inhibition (89-91) (reducing Ang II production) or blockade of the Ang II type 1 $\left(\mathrm{AT}_{1}\right)$ receptor (92) (blocking Ang II action) may be protective against the development of type 2 diabetes mellitus (93). These findings have led to discussion about the underlying mechanisms for these observations. The protective effect of reducing RAS activity against the development of diabetes has been explained by both metabolic and hemodynamic effects that may improve peripheral glucose metabolism and/or insulin secretion.

\section{$R A S$ and insulin resistance}

The effects of RAS blockade on insulin sensitivity have largely been attributed to improvements in peripheral glucose metabolism. Animal and cell studies have demonstrated that Ang II may induce insulin resistance by direct impairment of insulin signalling, and this detrimental effect of Ang II on insulin action could be reversed by RAS blockade (94-96). This is supported by findings of an improved insulin action on whole-body and skeletal muscle glucose disposal after ACE inhibitor treatment (97-106).

Furthermore, structural changes in adipose tissue due to RAS blockade may affect insulin sensitivity. It has been shown that Ang II inhibits differentiation of human preadipocytes (107), and exerts direct lipogenic effects in 3T3-L1 preadipocytes and human adipocytes (88). Therefore, it has been hypothesized that increased formation of Ang II by large adipocytes inhibits adipocyte differentiation, which may reduce the buffering capacity for lipid storage in adipose tissue, leading to increased storage of lipids in other tissues such as skeletal muscle, liver, and pancreas (108). This may induce insulin resistance, as discussed earlier in this chapter. Inhibition of lipolysis may further contribute to a reduced buffering capacity for lipid storage in the adipocyte. However, until now, results on the 
effects of Ang II on adipose tissue lipolysis have been controversial (109-112), and further research is warranted. Blockade of the RAS may therefore reverse insulin resistance by promoting the differentiation of preadipocytes and reducing lipogenesis, thereby counteracting ectopic fat deposition. This hypothesis is in line with the finding that the thiazolidinedione (TZD) insulin sensitizers stimulate adipocyte differentiation and increase the number of small adipocytes in rats (113, 114). These smaller adipocytes may possess a high buffering capacity for storage of excess energy. Indeed, it has been recently proposed that failure of adipocyte differentiation may underlie the development of type 2 diabetes (115).

\section{RAS and tissue blood flow}

Tissue-specific regulation of blood flow in tissues that are involved in metabolism is highly important, because blood flow determines the delivery of substrates and hormones to each tissue. Alterations in tissue blood flow may lead to disturbed tissue function. This section describes the association between disturbances in blood flow through adipose tissue and skeletal muscle and insulin resistance. Because of the potency of Ang II to induce vasoconstriction, it may well be that the RAS is involved in the disturbances in tissue blood flow observed in insulin resistance.

\section{Adipose tissue blood flow}

In lean, healthy subjects, adipose tissue blood flow (ATBF) is well-regulated, as demonstrated by an increase in ATBF after a meal. This increase in ATBF may be of great importance in the regulation of whole-body substrate metabolism (57). In obesity, both fasting ATBF (116-118) and ATBF responsiveness to nutrients (116, $117)$ are decreased, and this impairment is clearly associated with insulin resistance $(116,119)$. The importance of adequate blood flow regulation is further stressed by the fact that the extraction of circulating TAG in adipose tissue is increased when ATBF is increased pharmacologically (120). In line with this, a blunted ATBF is associated with risk factors for cardiovascular disease, such as increased blood pressure and insulin resistance $(116,119)$. Taken together, disturbances in ATBF regulation may underlie many aspects of insulin resistance and the accompanying cardiovascular risk.

It is well-established that Ang II exerts vasoconstrictive effects in the systemic circulation and is an important regulator of blood pressure (75). Therefore, it could be that Ang II decreases ATBF, thereby reducing TAG clearance in adipose tissue. 
This may lead to increased circulating concentrations of TAG and fatty acids and increased delivery of these substrates to other organs, such as skeletal muscle, resulting in IMTG accumulation in the insulin resistant muscle with a reduced oxidative capacity. On the other hand, the release of adipokines from adipose tissue may be disturbed when ATBF is decreased, which in turn may affect insulin sensitivity.

\section{Skeletal muscle blood flow}

The vascular system controls the delivery of nutrients and hormones to skeletal muscle. It has been reported that the insulin-mediated increase in muscle perfusion accounts for approximately $30 \%$ of the overall effect of insulin to stimulate glucose uptake in skeletal muscle, suggesting a role for insulin and glucose delivery as a determinant of insulin action (121). However, controversial data have been reported on the impact of insulin on skeletal muscle blood flow, as well as on the impact of skeletal muscle blood flow on glucose uptake in muscle. Theoretically, any endogenous agent that affects blood flow in skeletal muscle may affect glucose uptake. Furthermore, it should be emphasized that a reduced muscle blood flow may decrease the delivery of adipokines, such as adiponectin, to skeletal muscle, which may alter insulin sensitivity.

In addition to effects on ATBF, Ang II may also decrease skeletal muscle blood flow. Because of the potential role of skeletal muscle blood flow in glucose uptake (122), RAS blockade may contribute to improved glucose disposal by increasing blood flow through skeletal muscle, which may lead to and increased delivery of glucose, insulin, and perhaps important adipokines, to this tissue.

\section{$R A S$ and insulin secretion}

Activation of the local RAS within the pancreas may contribute to the progression of islet cell damage in diabetes, possibly by changes in islet blood flow, which consequently could lead to a reduced insulin release by the $\beta$-cells $(123,124)$. A reduced delivery of insulin to skeletal muscle may impair glucose uptake in this tissue. Blockade of the RAS indeed improved pancreatic islet morphology and function in rats (125), and it has been demonstrated in mice that it may also improve insulin secretion by the pancreas (126). Whether insulin secretion is indeed increased after RAS blockade and contributes to improved skeletal muscle glucose disposal in humans needs to be investigated. 
Not all clinical investigations have shown beneficial metabolic effects of ACE inhibitors (127-131). Furthermore, no reduction in progression to diabetes on ACE inhibitor therapy has been reported (132). Because several studies that examined the effect of ACE inhibitor treatment on insulin sensitivity are based on surrogate markers of insulin sensitivity, uncontrolled study designs, and are potentially confounded by the use of additional medication, further research is needed to assess the effects of RAS blockade on insulin sensitivity and possible underlying mechanisms.

\section{Concluding remarks}

Abdominal obesity may underlie many aspects of insulin resistance and cardiovascular disease and is an important risk factor for hypertension and the development of type 2 diabetes. Adipose tissue is not just a passive organ for energy storage, but has the ability to modulate its own metabolic activities, signal to other tissues to regulate their metabolism, and respond to several afferent signals. Thus, alterations in adipose tissue biology may have detrimental effects on metabolism. Since the recognition of adipose tissue as an endocrine organ, there has been great interest in the possibility that an adipose tissue-derived factor may contribute to the cluster of metabolic and hemodynamic disturbances often observed in obesity. It has recently been suggested that the RAS in adipose tissue may play an important role in obesity-related disorders (133-135).

However, important issues remain to be answered. There is substantial evidence that the RAS may exert metabolic and hemodynamic effects. Both animal and human studies support the idea that increased RAS activity may lead to insulin resistance and hypertension. With respect to increased RAS activity in obesity, it is tempting to postulate that the RAS in adipose tissue may exert endocrine effects, and may contribute to obesity-related disorders. However, direct evidence for this in vivo in humans is still lacking. Furthermore, observations that blockade of the RAS reduces the incidence of type 2 diabetes evoke the question what could be the explanation for these findings. It is therefore necessary to elucidate the effects of Ang II on mechanisms that may play a tole in the development of insulin resistance. 


\section{Outline of the thesis}

This thesis describes a variety of human studies designed to investigate the role of the RAS in obesity-related disorders. In chapter 2 , the possible involvement of the adipose tissue RAS in obesity and obesity-related disorders is extensively reviewed and possible implications of drugs that interfere with the RAS in the treatment of obesity-related hypertension and insulin resistance are highlighted. The endocrine role of the local RAS in adipose tissue and skeletal muscle, determined by measurements of arterio-venous differences across these tissues in combination with assessment of tissue blood flows, and the effect of $\beta$-adrenergic stimulation on the regulation of the RAS in lean and obese subjects are discussed in chapter 3. As mentioned earlier in this chapter, adipose tissue is actively involved in metabolism by responding to afferent signals and by signalling to other tissues to regulate their metabolism. In many cases, tissue-specific regulation of blood flow is necessary to regulate substrate delivery to tissues and allow signalling between tissues under varying physiological conditions. The effects of the vasoconstrictor Ang II on adipose tissue and skeletal muscle blood flow in normal-weight and obese subjects, assessed using the microdialysis technique, are discussed in chapter 4. Furthermore, chapter 4 describes the effects of Ang II on lipolysis in these tissues. With regard to the presence of a local RAS in adipose tissue, experiments were initiated to assess the functional importance of locally produced Ang II in adipose tissue and circulating Ang II that reaches adipose tissue in fasting and postprandial ATBF regulation. Because nitric oxide (NO) is a strong determinant of fasting ATBF, the interaction between Ang II and NO in ATBF regulation was also investigated. These experiments were performed using the recently developed microinfusion technique, and the results of these experiments are discussed in chapter 5. Chapter $\mathbf{6}$ addresses an in vitro approach to examine the effects of Ang II on lipolysis in abdominal subcutaneous adipocytes in normalweight and obese subjects into more detail, using Ang II stimulation in the presence and absence of $A T_{1}$ receptor blockade. Chapter 7 describes the results of a double-blind placebo-controlled randomized trial in which the effects of shortterm ACE inhibition on insulin sensitivity, forearm blood flow, substrate fluxes across the forearm, whole-body substrate oxidation, and IMTG content were investigated in obese, insulin resistant subjects. The clinical relevance of the issues that are dealt with in this thesis may become more evident in chapter 8 , which shows that RAS blockade is a frequently used strategy to treat obesity-related hypertension. Chapter 9 provides an overview of the main conclusions based on 
the studies described in this thesis. These conclusions are put into a broader perspective and important issues for future research will be addressed.

\section{References}

1. World Health Organization. Obesity: preventing and managing the global epidemic. Geneva, Switzerland, 1998. Publication WHO/NUT/NCD/98.91.

2. Flegal KM, Carroll MD, Ogden CL, Johnson CL. Prevalence and trends in obesity among US adults, 1999-2000. Jama 2002;288(14):1723-7.

3. Flegal KM. The obesity epidemic in children and adults: current evidence and tesearch issucs. Med Sci Sports Exerc 1999;31(11 Suppl):S509-14.

4. Visscher TL, Kromhout D, Seidell JC. Long-term and recent time trends in the prevalence of obesity among Dutch men and women. Int J Obes Relat Metab Disord 2002;26(?):1218-24.

5. Blokstra $A$, Schuit $A J$. Factsheet overgewicht: prevalentie en trend. RIVM-rapportnummer 260301/f1/2003. Bilthoven, 2003.

6. Schmidt I. Metabolic diseases: the environment determines the odds, even for genes. News Physiol Sci 2002;17:115-21.

7. Reaven GM. Banting lecture 1988. Role of insulin resistance in human disease. Diabetes 1988;37(12):1595-607.

8. Chan JM, Rimm EB, Colditz GA, Stampfer MJ, Willett WC. Obesity, fat distribution, and weight gain as risk factors for clinical diabetes in men. Diabetes Care 1994;17(9):961-9.

9. Han TS, Feskens EJ, Lean ME, Seidell JC. Associations of body composition with type 2 diabetes mellitus. Diabet Med 1998;15(2):129-35.

10. Grundy SM, Brewer HB, Jr., Cleeman JI, Smith SC, Jr., Lenfant C. Definition of metabolic syndrome: Report of the National Heart, Lung, and Blood Institute/American Heart Association conference on scientific issues related to definition. Circulation 2004;109(3):433-8.

11. Frayn KN. Adipose tissue and the insulin resistance syndrome. Proc Nutr Soc 2001;60(3):37580.

12. Jacob S, Machann J, Rett K, Brechtel K, Volk A, Renn W, et al. Association of increased intramyocellular lipid content with insulin resistance in lean nondiabetic offspring of type 2 diabetic subjects. Diabetes 1999;48(5):1113-9.

13. Forouhi NG, Jenkinson G, Thomas EL, Mullick S, Mierisova S, Bhonsle U, et al. Relation of triglyceride stores in skeletal muscle cells to central obesity and insulin sensitivity in European and South Asian men. Diabetologia 1999;42(8):932-5.

14. Pan DA, Lillioja S, Kriketos AD, Milner MR, Baur LA, Bogardus C, et al. Skeletal muscle triglyceride levels are inversely related to insulin action. Diabetes 1997;46(6):983-8.

15. Koyama $K$, Chen $G$, Lee $Y$, Unger RH. Tissue triglycerides, insulin resistance, and insulin production: implications for hyperinsulinemia of obesity. An J Physiol 1997;273(4 Pt 1):E70813.

16. Bjorntorp P. Liver triglycerides and metabolism. Int J Obes Relat Metab Disord 1995;19(12):839-40.

17. Banerji MA, Buckley MC, Chaiken RL, Gordon D, Lebovitz HE, Kral JG. Liver fat, serum triglycerides and visceral adipose tissue in insulin-sensitive and insulin-resistant black men with NIDDM. Int J Obes Relat Metab Disord 1995;19(12):846-50.

18. Ganda OP. Lipoatrophy, lipodystrophy, and insulin resistance. Ann Intern Med 2000;133(4):304-6.

19. Kim JK, Gavrilova O, Chen Y, Reitman ML, Shulman GI. Mechanism of insulin resistance in A-Z1P/ $\mathrm{I}^{\mathrm{3}}-1$ fatless mice. J Biol Chem 2000;275(12):8456-60.

20. Gavrilova O, Marcus-Samucls B, Graham D, Kim JK, Shulman GI, Castle AL, et al. Surgical implantation of adipose tissue reverses diabetes in lipoatrophic mice. J Clin Invest 2000;105(3):271-8.

21. Lewis GF, Vranic M, Harley $P$, Giacca $A$. Fatty acids mediate the acute extrahepatic effects of insulin on hepatic glucose production in humans. Diabetes 1997;46(7):1111-9. 
22. Fanelli C, Calderone S, Epifano L, De Vincenzo A, Modarelli F, Pampanelli S, et al. Demonstration of a critical role for free fatty acids in mediating counterregulatory stimulation of gluconeogenesis and suppression of glucose utilization in humans. J Clin Invest 1993;92(4):1617-22.

23. Ferrannini E, Barrett EJ, Bevilacqua S, DeFronzo RA. Effect of fatty acids on glucose production and utilization in man. J Clin Invest 1983;72(5):1737-47.

24. Byrne CD, Brindle NP, Wang TW, Hales CN. Interaction of non-esterified fatty acid and insulin in control of triacylglycerol secretion by Hep G2 cells. Biochem J 1991;280 ( Pt 1):99104.

25. Wiesenthal SR, Sandhu H, McCall RH, Tchipashvili V, Yoshii H, Polonsky K, et al. Free fatty acids impair hepatic insulin extraction in vivo. Diabetes 1999;48(4):766-74.

26. Hennes MM, Dua A, Kissebah AH. Effects of free fatty acids and glucose on splanchnic insulin dynamics. Diabetes 1997;46(1):57-62.

27. Svedberg J, Bjorntorp P, Smith U, Lonnroth P. Free-fatty acid inhibition of insulin binding, degradation, and action in isolated rat hepatocytes. Diabetes 1990;39(5):570-4.

28. Frayn $\mathrm{KN}$, Williams $\mathrm{CM}$, Amer $\mathrm{P}$. Are increased plasma non-esterified fatty acid concentrations a tisk marker for coronary heart disease and other chronic diseases? Clin Sci (Lond) 1996;90(4):243-53.

29. Maslowska MH, Sniderman AD, MacLean LD, Cianflone K. Regional differences in triacylglycerol synthesis in adipose tissue and in cultured preadipocytes. J Lipid Res $1993 ; 34(2): 219-28$.

30. Nielsen S, Guo Z, Johnson CM, Henstud DD, Jensen MD. Splanchnic lipolysis in human obesity. J Clin Invest 2004;113(11):1582-8.

31. Guo Z, Henstud DD, Johnson CM, Jensen MD. Regional postprandial fatty acid metabolism in different obesity phenotypes. Diabetes 1999;48(8):1586-92.

32. Martin ML, Jensen MD. Effects of body fat distribution on regional lipolysis in obesity. J Clin Invest 1991;88(2):609-13.

33. DeFronzo RA, Jacot E, Jequier E, Maeder E, Wahren J, Felber JP. The effect of insulin on the disposal of intravenous glucose. Results from indirect calorimetry and hepatic and femoral venous catheterization. Diabetes 1981;30(12):1000-7.

34. Goodpaster BH, Thate FL, Simoneau JA, Kelley DE. Subcutaneous abdominal fat and thigh muscle composition predict insulin sensitivity independently of visceral fat. Diabetes 1997;46(10):1579-85.

35. Kelley DE, Mandatino LJ. Fuel selection in human skeletal muscle in insulin resistance: a reexamination. Diabetes 2000;49(5):677-83.

36. Hulver MW, Dohm GL. The molecular mechanism linking muscle fat accumulation to insulin resistance. Proc Nutr Soc 2004;63(2):375-80.

37. Adams JM, 2nd, Pratipanawatr T, Berria R, Wang E, DeFtonzo RA, Sullards MC, et al. Ceramide content is increased in skeletal muscle from obese insulin-tesistant humans. Diabetes 2004;53(1):25-31.

38. Chavez JA, Knotts TA, Wang LP, Li G, Dobrowsky RT, Florant GL, et al. A role for ceramide, but not diacylglycerol, in the antagonism of insulin signal transduction by saturated fatty acids. J Biol Chem 2003;278(12):10297-303.

39. Yu C, Chen Y, Cline GW, Zhang D, Zong H, Wang Y, et al. Mechanism by which fatty acids inhibit insulin activation of insulin receptor substrate-1 (IRS-1)-associated phosphatidylinositol 3-kinase activity in muscle. J Biol Chem 2002;277(52):50230-6.

40. Itani SI, Ruderman NB, Schmieder F, Boden G. Lipid-induced insulin resistance in human muscle is associated with changes in diacylglycerol, protein kinase $C$, and IkappaB-alpha. Diabetes 2002;51(7):2005-11.

41. Prentki M, Corkey BE. Are the beta-cell signaling molecules malonyl-CoA and cystolic longchain acyl-Co $A$ implicated in multiple tissue defects of obesity and NIDDM? Diabetes 1996;45(3):273-83.

42. McGarty JD. Banting lecture 2001: dysregulation of fatty acid metabolism in the etiology of type 2 diabetes. Diabetes 2002;51(1):7-18. 
43. Blaak EE, van Aggel-Leijssen DP, Wagenmakers AJ, Saris WH, van Baak MA. Impaired oxidation of plasma-derived fatty acids in type 2 diabetic subjects during moderate-intensity exercise. Diabetes 2000;49(12):2102-7.

44. Kelley DE, Goodpaster B, Wing RR, Simoneau JA. Skeletal muscle fatty acid metabolism in association with insulin resistance, obesity, and weight loss. Am J Physiol 1999;277(6 Pt 1):E1130-41.

45. Mandarino LJ, Consoli A, Jain A, Kelley DE. Interaction of carbohydrate and fat fuels in human skeletal muscle: impact of obesity and NIDDM. Am J Physiol 1996;270(3 Pt 1):E46370 .

46. Colberg SR, Simoneau JA, Thaete FL, Kelley DE. Skeletal muscle utilization of free fatty acids in women with visceral obesity. J Clin Invest 1995;95(4):1846-53.

47. Kelley DE, Simoneau JA. Impaired free fatty acid utilization by skeletal muscle in non-insulindependent diabetes mellitus. J Clin Invest 1994;94(6):2349-56.

48. Blaak EE, Van Baak MA, Kemerink GJ, Pakbiers MT, Heidendal GA, Saris WH. Betaadrenergic stimulation of energy expenditure and forearm skeletal muscle metabolism in lean and obese men. Am J Physiol 1994;267(2 Pt 1):E306-15.

49. Simoneau JA, Veerkamp JH, Turcotte LP, Kelley DE. Markers of capacity to utilize fatty acids in human skeletal muscle: relation to insulin resistance and obesity and effects of weight loss. Faseb J 1999;13(14):2051-60.

50. Lowell BB, Shulman GI. Mitochondrial dysfunction and type 2 diabetes. Science 2005;307(5708):384-7.

51. Savage DB, Petersen KF, Shulman GI. Mechanisms of insulin resistance in humans and possible links with inflammation. Hypertension 2005;45(5):828-33.

52. Morino K, Petersen KF, Dufour S, Befroy D, Frattini J, Shatzkes N, et al. Reduced mitochondrial density and increased IRS-1 serine phosphorylation in muscle of insulintesistant offspring of type 2 diabetic parents. J Clin Invest 2005.

53. Petersen KF, Dufour S, Befroy D, Garcia R, Shulman GI. Impaired mitochondrial activity in the insulin-tesistant offspring of patients with type 2 diabetes. N Engl J Med 2004;350(7):66471.

54. Petersen KF, Befroy D, Dufour S, Dziura J, Ariyan C, Rothman DL, et al. Mitochondrial dysfunction in the elderly: possible role in insulin resistance. Science 2003;300(5622):1140-2.

55. Siiteri PK. Adipose tissue as a source of hormones. Am J Clin Nutr 1987;45(1 Suppl):277-82.

56. Kershaw EE, Flier JS. Adipose tissue as an endocrine organ. J Clin Endocrinol Metab 2004;89(6):2548-56.

57. Frayn KN, Karpe F, Fielding BA, Macdonald IA, Coppack SW. Integrative physiology of human adipose tissue. Int J Obes Relat Metab Disord 2003;27(8):875-88.

58. Hollenberg NK, Fisher ND, Price DA. Pathways for angiotensin II generation in intact human tissue: evidence from comparative pharmacological interruption of the renin system. Hypertension 1998;32(3):387-92.

59. Riordan JF. Angiotensin II: biosynthesis, molecular recognition, and signal transduction. Cell Mol Neurobiol 1995;15(6):637-51.

60. Phillips MI, Speakman EA, Kimura B. Levels of angiotensin and molecular biology of the tissue renin angiotensin systems. Regul Pept 1993;43(1-2):1-20.

61. Chai SY, Zhuo J, Mcndelsohn FA. Localization of components of the renin-angiotensin system and site of action of inhibitors. $\lambda$ rzneimittelforschung 1993;43(2A):214-21.

62. Dostal DE, Rothblum KN, Chernin MI, Cooper GR, Baker KM. Intracardiac detection of angiotensinogen and renin: a localized renin-angiotensin system in neonatal rat heart. Am J Physiol 1992;263(4 Pt 1):C838-50.

63. Mulrow PJ. Adrenal renin: regulation and function. Front Neuroendocrinol 1992;13(1):47-60.

64. Dzau VJ, Ellison KE, Brody $T$, Ingelfinger J, Pratt RE. A comparative study of the distributions of renin and angiotensinogen messenger ribonucleic acids in rat and mouse tissues. Endocrinology 1987;120(6):2334-8.

65. Murakami E, Eggena P, Barrett JD, Sambhi MP. Heterogeneity of renin substrate released from hepatocytes and in brain extracts. Life Sci 1984;34(4):385-92.

66. Schling P, Mallow $\mathrm{H}$, Trindl A, Loffler G. Evidence for a local renin angiotensin system in primary cultured human preadipocytes. Int J Obes Relat Metab Disord 1999;23(4):336-41. 
67. Karlsson C, Lindell K, Ottosson M, Sjostrom L, Carlsson B, Carlsson LM. Human adipose tissue expresses angiotensinogen and enzymes required for its conversion to angiotensin II. J Clin Endocrinol Metab 1998;83(11):3925-9.

68. Jones BH, Standridge MK, Taylor JW, Moustaid N. Angiotensinogen gene expression in adipose tissue: analysis of obese models and hormonal and nutritional control. Am J Physiol 1997;273(1 Pt 2):R236-42.

69. Jonsson JR, Game PA, Head RJ, Frewin DB. The expression and localisation of the angiotensin-converting enzyme mRNA in human adipose tissue. Blood Press 1994;3(1-2):72-5.

70. Crandall DL, Herzlinger HE, Saunders BD, Zolotor RC, Feliciano L, Cervoni P. Identification and characterization of angiotensin II receptors in rat epididymal adipocyte membranes. Metabolism 1993;42(4):511-5.

71. Cassis LA, Saye J, Peach MJ. Location and regulation of rat angiotensinogen messenger RNA. Hypertension 1988;11(6 Pt 2):591-6.

72. Genest J. Progress in hypertension research: 1900-2000. Hypertension 2001;38(4):E13-8.

73. Regitz-Zagrosek V, Neuss M, Holzmeister J, Warnecke C, Fleck E. Molecular biology of angiotensin receptors and their role in human cardiovascular disease. $\mathrm{J} \mathrm{Mol} \mathrm{Med}$ 1996;74(5):233-51.

74. Dzau VJ. Cell biology and genetics of angiotensin in cardiovascular disease. J Hypertens Suppl 1994;12(4):S3-10.

75. Timmermans PB, Wong PC, Chiu AT, Herblin WF, Benfield P, Carini DJ, et al. Angiotensin II receptors and angiotensin II receptor antagonists. Pharmacol Rev 1993;45(2):205-51.

76. Johnston CI. Biochemistry and pharmacology of the renin-angiotensin system. Drugs 1990;39(Suppl 1):21-31.

77. Reid IA, Morris BJ, Ganong WF. The renin-angiotensin system. Annu Rev Physiol 1978;40:377-410.

78. Engeli S, Bohnke J, Gorzelniak K, Janke J, Schling P, Bader M, et al. Weight Loss and the Renin-Angiotensin-Aldosterone System. Hypertension 2005.

79. Cooper R, Forrester T, Ogunbiyi O, Muffinda J. Angiotensinogen levels and obesity in four black populations. ICSHIB Investigators. J Hypertens 1998;16(5):571-5.

80. Cooper R, McFarlane-Anderson N, Bennett FI, Wilks R, Puras A, Tewksbury D, et al. ACE, angiotensinogen and obesity: a potential pathway leading to hypertension. J Hum Hypertens 1997;11(2):107-11.

81. Umemura S, Nyui N, Tamura K, Hibi K, Yamaguchi S, Nakamatu M, et al. Plasma angiotensinogen concentrations in obese patients. Am J Hypertens 1997;10(6):629-33.

82. Bloem LJ, Manatunga AK, Tewksbury DA, Pratt JH. The serum angiotensinogen concentration and variants of the angiotensinogen gene in white and black children. $J$ Clin Invest 1995;95(3):948-53.

83. Licata G, Scaglione R, Ganguzza A, Corrao S; Donatelli M, Parrinello G, et al. Central obesity and hypertension. Relationship between fasting serum insulin, plasma renin activity, and diastolic blood pressure in young obese subjects. Am J Hypertens 1994;7(4 Pt 1):314-20.

84. Egan BM, Stepniakowski K, Goodfriend TL. Renin and aldosterone are higher and the hyperinsulinemic effect of salt restriction greater in subjects with risk factors clustering. Am J Hypertens 1994;7(10 Pt 1):886-93.

85. Unger $\mathrm{T}$. The role of the renin-angiotensin system in the development of cardiovascular disease. Am J Cardiol 2002;89(2A):3A-9A; discussion 10A.

86. Kim S, Iwao H. Molecular and cellular mechanisms of angiotensin II-mediated cardiovascular and renal diseases. Pharmacol Rev 2000;52(1):11-34.

87. Massiera F, Bloch-Faure M, Ceiler D, Murakami K, Fukamizu A, Gasc JM, et al. Adipose angiotensinogen is involved in adipose tissue growth and blood pressure regulation. Faseb J 2001;15(14):2727-9.

88. Jones BH, Standridge MK, Moustaid N. Angiotensin II increases lipogenesis in 3T3-L1 and human adipose cells. Endocrinology 1997;138(4):1512-9.

89. Yusuf S, Sleight P, Pogue J, Bosch J, Davies R, Dagenais G. Effects of an angiotensinconverting-enzyme inhibitor, ramipril, on cardiovascular events in high-risk patients. The Heart Outcomes Prevention Evaluation Study Investigators. N Engl J Med 2000;342(3):14553. 
90. Hansson L, Lindholm LH, Niskanen L, Lanke J, Hedner T, Niklason $A$, et al. Effect of angiotensin-converting-enzyme inhibition compared with conventional therapy on cardiovascular morbidity and mortality in hypertension: the Captopril Prevention Project (CAPPP) randomised trial. Lancet 1999;353(9153):611-6.

91. Torlone E, Britta M, Rambotti $A M$, Perriello $G$, Santeusanio $F$, Bruncti $P$, et al. Improved insulin action and glycemic control after long-term angiotensin-convcrting enzyme inhibition in subjects with arterial hypertension and type II diabetes. Diabetes Care 1993;16(10):1347-55.

92. Dahlof B, Devereux RB, Kjeldsen SE, Julius S, Beevers G, de Faire U, et al. Cardiovascular morbidity and mortality in the Losartan Intervention For Endpoint reduction in hypertension study (LIFE): a randomised trial against atenolol. Lancet 2002;359(9311):995-1003.

93. Jandeleit-Dahm KA, Tikellis C, Reid CM, Johnston CI, Cooper ME. Why blockade of the renin-angiotensin system reduces the incidence of new-onset diabetes. J Hypertens 2005;23(3):463-73.

94. Henriksen EJ, Jacob S, Kinnick TR, Teachey MK, Krekler M. Selective angiotensin II receptor receptor antagonism reduces insulin resistance in obese Zucker rats. Hypertension 2001;38(4):884-90.

95. Folli $\mathrm{I}^{7}$, Kahn CR, Hansen $\mathrm{H}$, Bouchic $\mathrm{J}$, Fecner EP. Angiotensin II inhibits insulin signaling in aortic smooth muscle cells at multiple levels. A porential role for serine phosphorylation in insulin/angiotensin II crosstalk. J Clin Invest 1997;100(9):2158-69.

96. Velloso LA, Folli F, Sun XJ, White MF, Saad MJ, Kahn CR. Cross-talk between the insulin and angiotensin signaling systems. Proc Natl Acad Sci U S A 1996;93(22):12490-5.

97. Lender D, Arauz-Pacheco C, Breen L, Mora-Mora P, Ramirez LC, Raskin P. A double blind comparison of the effects of amlodipine and enalaptil on insulin sensitivity in hypertensive patients. Am J Hypertens 1999;12(3):298-303.

98. Shamiss A, Carroll J, Peleg E, Grossman E, Rosenthal T. The effect of enalapril with and without hydrochlorothiazide on insulin sensitivity and other metabolic abnormalities of hypertensive patients with NIDDM. Am J Hypertens 1995;8(3):276-81.

99. Suzuki M, Ikebuchi M, Yokota C, Shinozaki K, Harano Y. Normalization of insulin resistance in non-obese essential hypertension by cilazapril treatment. Clin Exp Hypertens 1995;17(8):1257-68.

100. Vuorinen-Markkola H, Yki-Jarvinen H. Antihypertensive therapy with enalapril improves glucose storage and insulin sensitivity in hypertensive patients with non-insulin-dependent diabetes mellitus. Metabolism 1995;44(1):85-9.

101. Morel Y, Gadient A, Keller U, Vadas L, Golay A. Insulin sensitivity in obese hypertensive dyslipidemic patients treated with enalapril or atenolol. I Cardiovasc Pharmacol 1995;26(2):306-11.

102. Paolisso G, Gambardella A, Verza M, D'Amore A, Sgambato S, Varricchio M. ACE inhibition improves insulin-sensitivity in aged insulin-resistant hypertensive patients. J Hum Hypertens 1992;6(3):175-9.

103. Shich SM, Sheu WH, Shen DD, Fuh MM, Jeng CY, Jeng JR, et al. Improvement in metabolic risk factors for coronary heart disease associated with cilazapril treatment. Am J Hypertens 1992;5(8):506-10.

104. Torlone E, Rambotti AM, Perriello G, Botta G, Santeusanio F, Brunetti P, et al. ACEinhibition increases hepatic and extrahepatic sensitivity to insulin in patients with type 2 (noninsulin-dependent) diabetes mellitus and arterial hypertension. Diabetologia 1991;34(2):119-25.

105. Pollare T, Lithell H, Berne C. A comparison of the effects of hydrochlorothiazide and captopril on glucose and lipid metabolism in patients with hypertension. $N$ Engl J Med 1989;321(13):868-73.

106. Jauch KW, Hart W, Guenther B, Wicklmayr M, Rett K, Dictze G. Captopril enhances insulin responsiveness of forearn muscle tissue in non-insulin-dependent diabetes mellitus. Eur J Clin Invest 1987;17(5):448-54

107. Janke J, Engeli S, Gorzelnial K, luft FC, Sharma AM. Mature adipocytes inhibit in vitro differentiation of human preadipocytes via angiotensin type 1 receptors. Diabetes 2002;51(6):1699-707

108. Sharma AM, Janke I, Gorzelniak K, Engeli S, Luft I.C. Angiotensin blockade prevents type 2 diabetes by formation of fat cells. Hypertension 2002;40(5):609-11 
109. Boschmann M, Jordan J, Adams F, Christensen NJ, Tank J, Franke G, et al. Tissue-specific response to interstitial angiotensin II in humans. Hypertension 2003;41(1):37-41.

110. Boschmann M, Jordan J, Schmidt S, Adams F, Luft FC, Klaus S. Gender-Specific Response to Interstitial Angiotensin II in Human White Adipose Tissue. Horm Metab Res 2002;34(1112):726-30.

111. Boschmann M, Ringel J, Klaus S, Sharma AM. Metabolic and hemodynamic response of adipose tissue to angiotensin II. Obes Res 2001;9(8):486-91.

112. Cabassi A, Coghi P, Govoni P, Barouhiel E, Speroni E, Cavazzini S, et al. Sympathetic modulation by carvedilol and losartan reduces angiotensin II-mediated lipolysis in subcutaneous and visceral fat. J Clin Endocrinol Metab 2005.

113. Okuno A, Tamemoto H, Tobe K, Ueki K, Mori Y, Iwamoto K, et al. Troglitazone increases the number of small adipocytes without the change of white adipose tissue mass in obese Zucker rats. J Clin Invest 1998;101(6):1354-61.

114. Hallakou S, Doare L, Foufelle F, Kergoat M, Guerre-Millo M, Berthault MF, et al. Pioglitazone induces in vivo adipocyte differentiation in the obese Zucker $\mathrm{fa} / \mathrm{fa}$ rat. Diabetes 1997;46(9):1393-9.

115. Danforth E, Jr. Failure of adipocyte differentiation causes type II diabetes mellitus? Nat Genet 2000;26(1):13.

116. Jansson PA, Larsson A, Lonnroth PN. Relationship between blood pressure, metabolic variables and blood flow in obese subjects with or without non-insulin-dependent diabetes mellitus. Eur J Clin Invest 1998;28(10):813-8.

117. Summers LK, Samra JS, Humphreys SM, Morris RJ, Frayn KN. Subcutaneous abdominal adipose tissue blood flow: variation within and between subjects and relationship to obesity. Clin Sci (Lond) 1996;91(6):679-83.

118. Blaak EE, van Baak MA, Kemerink GJ, Pakbiers MT, Heidendal GA, Saris WH. Betaadrenergic stimulation and abdominal subcutaneous fat blood flow in lean, obese, and reducedobese subjects. Metabolism 1995;44(2):183-7.

119. Karpe F, Fielding BA, Ilic V, Macdonald IA, Summers LK, Frayn KN. Impaired postprandial adipose tissue blood flow response is related to aspects of insulin sensitivity. Diabctes 2002;51(8):2467-73.

120. Samra JS, Simpson EJ, Clark ML, Forster CD, Humphreys SM, Macdonald IA, et al. Effects of epinephrine infusion on adipose tissue: interactions between blood flow and lipid metabolism. Am J Physiol 1996;271(5 Pt 1):E834-9.

121. Baron AD, Clark MG. Role of blood flow in the regulation of muscle glucose uptake. Annu Rev Nutr 1997;17:487-99.

122. Edelman SV, Laakso M, Wallace P, Btechtel G, Olefsky JM, Baron AD. Kinetics of insulinmediated and non-insulin-mediated glucose uptake in humans. Diabetes 1990;39(8):955-64.

123. Tahmasebi M, Puddefoot JR, Inwang ER, Vinson GP. The tissue renin-angiotensin system in human pancreas. J Endocrinol 1999;161(2):317-22.

124. Carlsson PO, Berne C, Jansson L. Angiotensin II and the endocrine pancreas: effects on islet blood flow and insulin secretion in rats. Diabetologia 1998;41(2):127-33.

125. Tikellis C, Wookey PJ, Candido R, Andrikopoulos S, Thomas MC, Cooper ME. Improved islet morphology after blockade of the renin-angiotensin system in the ZDF rat. Diabetes 2004;53(4):989-97.

126. Kampf C, Lau T, Olsson R, Leung PS, Carlsson PO. Angiotensin II type 1 receptor inhibition markedly improves the blood perfusion, oxygen tension and first phase of glucose-stimulated insulin secretion in revascularised syngeneic mouse islet grafts. Diabetologia 2005;48(6):115967.

127. Petrie JR, Morris AD, Ueda S, Small M, Donnelly R, Connell JM, et al. Trandolapril does not improve insulin sensitivity in patients with hypertension and type 2 diabetes: a double-blind, placebo-controlled crossover trial. J Clin Endocrinol Metab 2000;85(5):1882-9.

128. New JP, Bilous RW, Walker M. Insulin sensitivity in hypertensive Type 2 diabetic patients after 1 and 19 days' treatment with trandolapril. Diabet Med 2000;17(2):134-40.

129. Heise T, Heinemann L, Kristahn K, Berger M, Sawicki PT. Insulin sensitivity in patients with essential hypertension: no influence of the ACE inhibitor enalapril. Horm Metab Res $1999 ; 31(7): 418-23$. 
130. Heinemann L, Heise T, Ampudia J, Sawicki P, Sindelka G, Brunner G, et al. Four week administration of an ACE inhibitor and a cardioselective beta-blocker in healthy volunteers: no influence on insulin sensitivity. Eur J Clin Invest 1995;25(8):595-600.

131. Reaven GM, Clinkingbeard C, Jeppesen J, Maheux P, Pei D, Foote J, et al. Comparison of the hemodynamic and metabolic effects of low-dose hydrochlorothiazide and lisinopril treatment in obese patients with high blood pressure. Am J Hypertens 1995;8(5 Pt 1):461-6.

132. Gress TW, Nieto FJ, Shahar E, Wofford MR, Brancati FL. Hypertension and antihypertensive therapy as risk factors for type 2 diabetes mellitus. Atherosclerosis Risk in Communities Study. N Engl J Med 2000;342(13):905-12.

133. Goossens GH, Blaak EE, van Baak MA. Possible involvement of the adipose tissue reninangiotensin system in the pathophysiology of obesity and obesity-related disorders. Obes Rev $2003 ; 4(1): 43-55$.

134. Engeli S, Schling P, Gorzelniak K, Boschmann M, Janke J, Ailhaud G, et al. The adipose-tissue renin-angiotensin-aldosterone system: role in the metabolic syndrome? Int J Biochem Cell Biol 2003;35(6):807-25.

135. Strazzullo P, Galletti F. Impact of the renin-angiotensin system on lipid and carbohydrate metabolism. Curr Opin Nephrol Hypertens 2004;13(3):325-32. 
- 


\section{2}

Possible involvement of the adipose tissue renin-angiotensin system in the pathophysiology of obesity and obesity-related disorders

Gijs H. Goossens, Ellen E. Blaak and Marleen A. van Baak

Department of Human Biology, Nutrition and Toxicology Research Institute Maastricht (NUTRIM), Maastricht University, Maastricht, The Netherlands

Obes Rev 2003;4(1):43-55 


\begin{abstract}
Angiotensin II (Ang II), acting on the $\mathrm{AT}_{1}$ and $\mathrm{AT}_{2}$ receptors in mammalian cells, is the vasoactive component of the renin-angiotensin system (RAS). Several components of the RAS have been demonstrated in different tissues, including adipose tissue. Although the effects of Ang II on metabolism have not been studied widely, it is intriguing to assume that components of the RAS produced by adipocytes may play an autocrine, a paracrine and/or an endocrine role in the pathophysiology of obesity and provide a potential pathway through which obesity leads to hypertension and type 2 diabetes mellitus. In the first part of this review, we will describe the production of Ang II, the different receptors through which Ang II exerts its effects and summarize the concomitant intracellular signalling cascades. Thereafter, potential Ang II-induced mechanisms, which may be associated with obesity and obesity-related disorders, will be considered. Finally, we will focus on the different pharmaceutical agents that interfere with the RAS and highlight the possible implications of these drugs in the treatment of obesityrelated disorders.
\end{abstract}




\section{The renin-angiotensin system and production of angiotensin II}

Angiotensin II (Ang II), an octapeptide hormone, is the active component of the renin-angiotensin system (RAS). In the classical RAS, circulating renal-derived renin cleaves angiotensinogen (AGT), a protein principally synthesized in the liver (1), to form the decapeptide angiotensin I (Ang I), an inactive substance (figure 2.1). Subsequently, conversion of Ang I to Ang II occurs rapidly by the action of the dipeptidyl carboxypeptidase angiotensin-converting enzyme (ACE) in the lungs (2-6). Ang I can also be processed into the active heptapeptide Ang-(1-7) by neutral endopeptidases. Ang II is then degraded to angiotensin III and IV, which appear to be active as well, by aminopeptidases (7).

Besides the conversion of Ang I to Ang II by means of ACE, accumulating evidence indicates the existence of an alternative (ACE-independent) pathway for generation of Ang II. It has been suggested that chymotrypsin-like protease (chymase), which is a potent and specific Ang II-forming serine protease that is not affected by ACE inhibitors, plays a functional role in Ang II formation in human vascular tissue (8) and in the carotid artery of the dog (9). Furthermore, chymase may be involved in Ang II synthesis in the human heart (10-13) and kidney (8). The possible contribution of non-ACE pathways to in vivo Ang II formation remains to be established, because most approaches used so far have

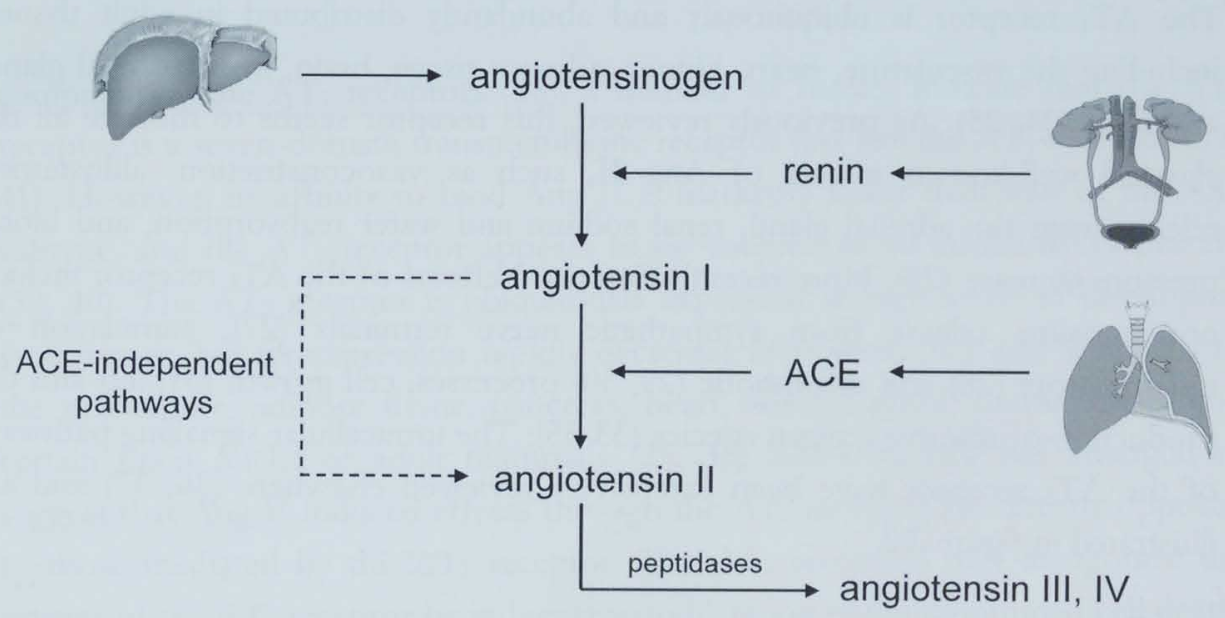

Figure 2.1 The classical renin-angiotensin system. Circulating renal-derived renin cleaves angiotensinogen, which is principally synthesized in the liver, to form angiotensin I (Ang I). Subsequently, Ang I is converted to Ang II by angiotensin-converting enzyme (ACE) in the lungs and possibly by ACE-independent pathways. Ang II is further metabolized by aminopeptidases. 
not made it possible to extrapolate from the in vitro to the in vivo situation. Clarification of the mechanisms of the tissue Ang II formation in humans, especially in pathological conditions, may open new possibilities for therapeutic interventions.

\section{Physiological role of Ang II receptors}

Multiple lines of evidence have demonstrated the existence of Ang II receptors and at least two distinct subtypes of cell-surface receptors, $\mathrm{AT}_{1}$ and $\mathrm{AT}_{2}$, have been defined in mammalian cells based on their differential pharmacological and biochemical properties $(14,15)$. Two other angiotensin receptors, the $\mathrm{AT}_{3}$ and $\mathrm{AT}_{4}$ subtypes, have been demonstrated $(16,17)$, but they have not been fully characterized yet. Detailed reviews dealing with the biochemical properties and molecular biology of the $\mathrm{AT}_{1}(18,19)$ and $\mathrm{AT}_{2}$ receptors $(18,20)$ have previously been published.

\section{AT, receptor}

The $A T_{1}$ receptor belongs to the seven membrane-spanning $G$ protein-coupled receptor family and exerts its effects through the heterotrimeric Gq protein (21, 22). Two $A T_{1}$ receptor subtypes, $A T_{1 A}$ and $A T_{1 B}$, which have a homology with regard to amino acid sequence of about $95 \%$, have been described in rodents (23). The $\mathrm{AT}_{1}$ receptor is ubiquitously and abundantly distributed in adult tissues, including the vasculature, heart, kidney, adipose tissue, brain, liver, adrenal gland, and lung $(24,25)$. As previously reviewed, this receptor seems to mediate all the classical well-known effects of Ang II, such as vasoconstriction, aldosterone release from the adrenal gland, renal sodium and water reabsorption, and blood pressure increase (26). More recently described effects of the $A T_{1}$ receptor include noradrenaline release from sympathetic nerve terminals (27), stimulation of inflammatory $(28)$ and thrombotic $(29,30)$ processes, cell growth $(31,32)$ and the production of reactive oxygen species (33-35). The intracellular signalling pathways of the $A T_{1}$ receptor have been extensively reviewed elsewhere $(36,37)$ and are illustrated in figure 2.2 .

$A T_{2}$ receptor

Although the $\mathrm{AT}_{2}$ receptor has low homology with regard to amino acid sequence 


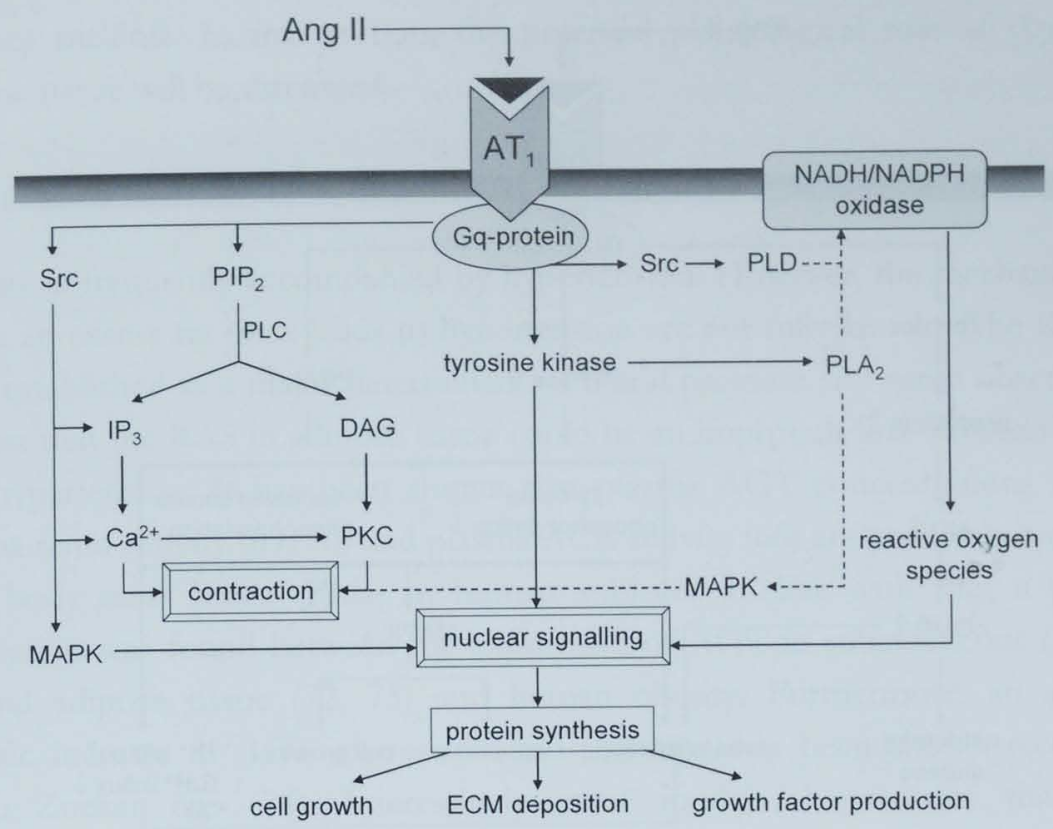

Figure 2.2 Binding of angiotensin II (Ang II) to the angiotensin type $1\left(\mathrm{AT}_{1}\right)$ receptor evokes several intracellular signalling events, such as activation of PLC, Src, tyrosine kinases, MAPK, PLA 2 , PLD and generation of reactive oxygen species, leading to contraction and nuclear signalling. $\mathrm{PIP}_{2}$, phosphatidylinositol-4,5-biphosphate; $\mathrm{IP}_{3}$, inositol-1,4,5-triphosphate; $\mathrm{DAG}$, diacylglycerol; PLA 2 , PLC, PLD, phospholipase $A_{2}, C$ and D, respectively; PKC, protein kinase C; Src, Src family of protein tyrosine kinases; MAPK, mitogen-activated protein kinase; $\mathrm{Ca}^{2+}$, intracellular calcium; ECM, extracellular matrix.

compared to the $A T_{1}$ receptors (38), a number of studies indicate that the $A T_{2}$ receptor is a seven-domain transmembrane receptor just like the $\mathrm{AT}_{1}$ receptor (3941). However, its affinity to bind Ang II is markedly lower than that of the $A T_{1}$ subtype, and the $\mathrm{AT}_{2}$ receptor appears to be coupled to an inhibitory $\mathrm{G}$ protein $(39,40)$. The $\mathrm{AT}_{2}$ receptor is ubiquitously expressed at high levels in developing fetal tissues, but its expression rapidly decreases after birth (42) and is limited to the vasculature, adipose tissue, pancreas, heart, adrenal gland, uterus, ovary and certain brain nuclei of adult mammals $(25,36,37)$. Evidence has emerged to suggest that Ang II-induced effects through the $\mathrm{AT}_{2}$ receptor are directly opposed to those mediated by the $A T_{1}$ receptor. The $A T_{2}$ receptors may antagonize the actions of the $\mathrm{AT}_{1}$ receptor by inducing vasodilatation and programmed cell death, and by inhibiting cell growth and proliferation (20,40, 43-48). However, the exact physiological role of this receptor awaits clarification. The current knowledge of 


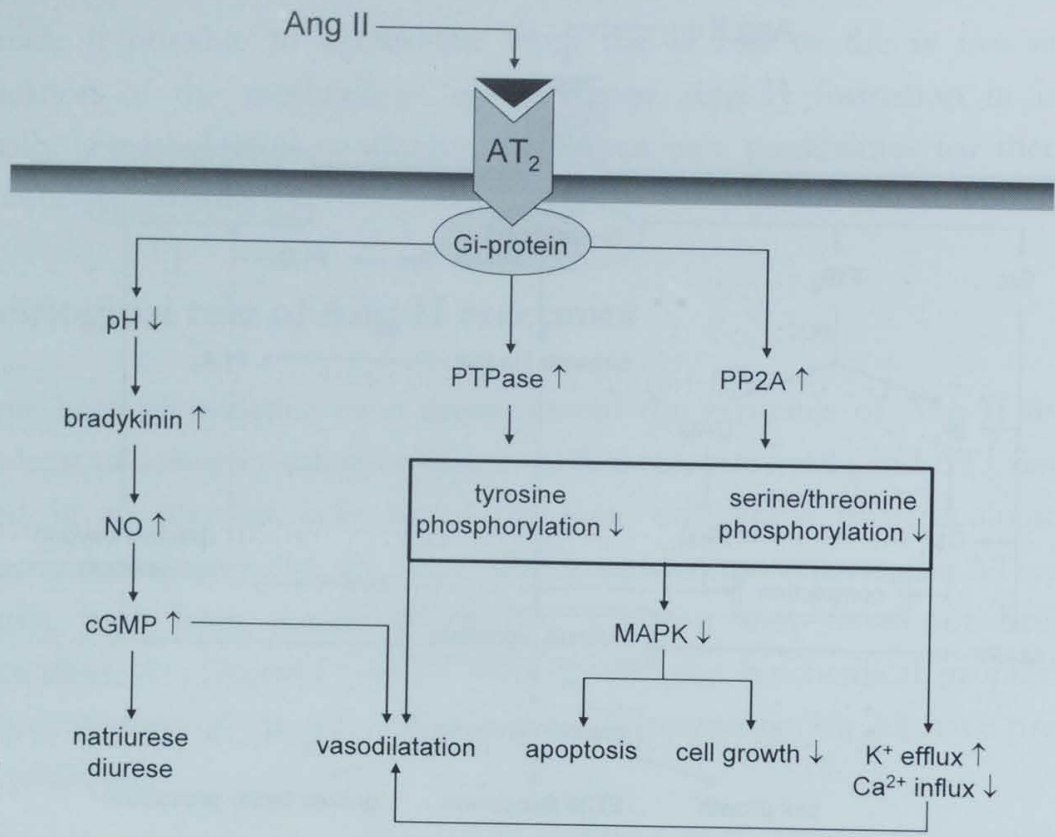

Figure 2.3 Postulated angiotensin type $2\left(\mathrm{AT}_{2}\right)$ receptor-mediated intracellular signalling. Activation of $\mathrm{AT}_{2}$ results in the production of $\mathrm{NO}$ and activation of several phosphatases, such as PTPase and $\mathrm{PP} 2 \mathrm{~A}$, resulting in inactivation of MAPK and changes in the potassium and calcium current. Ang II, angiotensin II; Gi-protein, inhibitory G protein; NO, nitric oxide; PTPase, protein tyrosine phosphatase; PP2A, serine/threonine phosphatase 2A; MAPK, mitogen-activated protein kinase; cGMP, cyclic guanosine monophosphate; $\mathrm{K}^{+}$, potassium; $\mathrm{Ca}^{2+}$, calcium.

the intracellular signalling pathways of the $\mathrm{AT}_{2}$ receptor has been reviewed previously (36) and is shown in figure 2.3 .

\section{Physiology of the adipose tissue RAS}

In addition to the classical pathway of Ang II synthesis, several components of the RAS have been identified in a variety of tissues, such as the adrenal gland, kidney, liver, heart, blood vessels, brain and reproductive organs (3, 8, 49-54), implying that these tissues have the ability to synthesize Ang II independently of the systemic RAS $(3,55)$. Although the evidence of in vivo Ang II formation in adipose tissue has not been delivered yet, the presence of several components of the RAS in this tissue has been demonstrated (56-61), suggesting a local adipose tissue RAS $(3,62-64)$. The physiological effects of the RAS in adipose tissue have not been studied widely. However, potential Ang II-induced mechanisms may be associated with obesity and obesity-related disorders, such as hypertension and type 2 
diabetes mellitus. In this section, the potential physiological role of Ang II in adipose tissue will be discussed.

\section{$R A S$ in adipose tissue}

Obesity is frequently accompanied by hypertension. However, the mechanisms by which an excess fat mass leads to hypertension are not fully known. The RAS has been established as a major determinant of blood pressure and some observations suggest that the RAS in adipose tissue could be an important link between obesity and hypertension. It has been shown that plasma AGT concentrations (65-68), plasma renin activity $(69,70)$ and plasma ACE activity (66) are positively correlated with body mass index (BMI) in human subjects. In line with this, a positive correlation was found between the expression of AGT in subcutaneous (71) and visceral adipose tissue $(72,73)$ and human obesity. Furthermore, an adiposespecific increase in AGT expression and secretion has been shown recently in obese Zucker rats (74). Interestingly, mice models demonstrate that AGT produced by adipose tissue plays a role both in local adipose tissue development and in the endocrine system (75). Therefore, with regard to the adipose mass in obese individuals, it is intriguing to assume that components of the RAS produced by adipocytes may play an autocrine, a paracrine, and/or an endocrine role in the pathophysiology of obesity and provide a potential pathway through which obesity leads to hypertension $(76,77)$.

\section{Regulation of RAS in adipose tissue}

There is evidence that the expression of AGT is nutritionally and hormonally regulated in adipose tissue $(58,78-80)$. Fasting resulted in a reduction of AGT mRNA expression and AGT secretion in white adipocytes of rats while refeeding resulted in an increase in both events. These local changes in AGT expression in adipocytes were accompanied by parallel changes in blood pressure, falling on fasting and increasing during refeeding (78). However, plasma AGT concentrations did not change in this study. AGT gene expression in preadipocytes is positively regulated by fatty acids (79). The effects of insulin on AGT expression are inconsistent. Both downregulation (80) and upregulation (58) of AGT mRNA expression by insulin have been reported. Thus, there might be a possible link between food intake and the regulation of adipose tissue AGT mRNA expression. Furthermore, $\beta$-adrenergic stimulation seems to be involved in the regulation of the RAS, although little is known about this relationship in adipose tissue. It has 
been reported that AGT mRNA expression in 3T3-L1 adipocytes is downregulated by $\beta$-adrenergic stimulation (58). In other tissues, upregulation of AGT mRNA by $\beta$-adrenergic stimulation has been reported $(81,82)$ and several studies indicate that $\beta$-adrenergic stimulation increases renin release (83-87), renin activity (88), Ang II release (89), and the stimulatory potential of Ang II on aldosterone release (90). Therefore, $\beta$-adrenergic stimulation may also stimulate the RAS in adipose tissue.

In summary, there is some evidence that the RAS in adipose tissue is regulated by nutritional and hormonal factors and possibly by $\beta$-adrenergic stimulation. In order to increase our understanding of the mechanisms underlying variations in RAS activity, it would be helpful to identify these regulating factors and find out more about the way they act.

\section{Ang II-induced effects on adipocyte growth and differentiation}

As discussed earlier, Ang II acts as a growth factor in a variety of tissues and cells $(31,32,91)$, and recent data suggest that Ang II may also play a role in adipocyte growth and differentation (92-95). Prostaglandin $\mathrm{I}_{2}\left(\mathrm{PGI}_{2}\right)$, a major metabolite of arachidonic acid in rodent and human adipose tissue $(96-98)$, is a potent and specific autocrine stimulator of adipocyte differentiation (95, 99-103). Interestingly, $\mathrm{PGI}_{2}$ release by adipocytes is stimulated by Ang II, both in vitro $(95,104)$ and in vivo (105). Therefore, it can be assumed that Ang II, derived from AGT secreted by mature adipocytes, may act in a paracrine way to induce the production and release of $\mathrm{PGI}_{2}$, thereby promoting adipocyte differentiation of preadipocytes into mature adipocytes. Furthermore, direct hypertrophic effects of Ang II have been demonstrated in differentiated murine $3 T 3-L 1$ preadipocytes and human adipocytes (106). Besides elevating triglyceride content in both these cell types, Ang II increased the activity and transcription rate of the lipogenic enzymes glycerol-3-phosphate dehydrogenase and fatty acid synthase (106). The Ang IIinduced regulation of adipocyte fatty acid synthase gene transcription may be mediated through insulin response sequences in a glucose-dependent manner (107). These lipogenic effects were attenuated by angiotensin receptor blockade, indicating involvement of Ang II in these events (106).

However, some contrary findings have been reported recently. It has been shown that Ang II induces inhibition of adipose tissue differentiation in cultured human preadipocytes mediated by the $A T_{1}$ receptor (108). In this study, adipocytes were able to inhibit preadipocyte differentiation, suggesting a paracrine negative feedback loop that inhibits further differentiation from preadipocytes to mature adipocytes. Furthermore, Ang II has been found to lead to a distinct reduction in 
insulin-induced adipocyte differentiation (109). Thus, there is also evidence that Ang II may inhibit the differentiation of adipose tissue. In conclusion, the effects of Ang II on adipocyte growth and differentiation are not yet clear and remain to be established.

\section{Ang II-induced effects on adipose tissue blood flow and lipolysis}

Obviously, adipose tissue not only contains adipocytes, but also fibroblast-like cells (e.g. preadipocytes), endothelial cells, vascular smooth muscle cells, mononuclear cells and lymphocytic cells (25). Therefore, many of the Ang II-induced effects described for other tissues, such as vasoconstriction, may also be applicable for adipose tissue. Indeed, the vasocontrictive effect of Ang II has also been demonstrated in adipose tissue. Infusion of Ang II, using the microdialysis technique, resulted in a reduction in adipose tissue blood flow (ATBF), which was more pronounced in femoral subcutaneous than in abdominal subcutaneous adipose tissue (110). The Ang II-induced reduction in ATBF could result in accumulation of free fatty acids (FFAs) or a decrease in intracellular $\mathrm{pH}$, as demonstrated by a rise in lactate concentration in the dialysate (110), thereby inhibiting lipolysis (111). In addition, accumulation of FFA could lead to an increased fatty acid reesterification. Both inhibition of lipolysis and FFA accumulation may then increase fat storage. It has been generally assumed that adipose tissue relies on glucose to provide glycerol-3-phosphate for reesterification. Therefore, there is an apparent discrepancy between an Ang IIinduced reduction in glucose uptake, as suggested by Boschmann et al. (110), and a concomitant increase in fatty acid reesterification. To elucidate this discrepancy, more studies on the effect of Ang II on adipose tissue metabolism are required. In this context, there are some recent findings of interest from our group (112) and others (113), which suggest that there may be glycerol uptake by adipose tissue. Hence, glycerol may be the precursor for triacylglycerol formation in this tissue. Obviously, these preliminary findings need confirmation.

It has been shown that basal abdominal subcutaneous ATBF, expressed per unit fat mass, was significantly lower in obese than in lean subjects (114). In line with this, weight reduction significantly increased basal ATBF (114). Thus, it can be hypothesized that an excess secretion of Ang II by adipose tissue reduces ATBF and may induce an inhibition of lipolysis, leading to an elevated fatty acid reesterification and, thereby, an increased fat mass in obese subjects.

There is some evidence that the possible antilipolytic actions of Ang II may not only result from indirect effects secondary to an Ang II-induced reduction in 
ATBF, but may also be attributed to Ang II action on the sympathetic nervous system. Under resting conditions, lipolysis is primarily regulated (inhibited) by the activity of $\alpha_{2}$-adrenergic receptors $(115,116)$ and Ang II has been demonstrated to augment the release of noradrenaline from brown adipose tissue sympathetic nerve terminals (27). Moreover, responsiveness to this presynaptic effect of Ang II was elevated following chronic Ang II infusion (27). Therefore, the antilipolytic effects of Ang II may also be the result of stimulation or potentiation of $\alpha$-adrenergic activity. However, there is also evidence that Ang II may not be involved in lipolysis, at least at the whole-body level (117). Postabsorptive whole-body lipolytic activity was measured using the stable isotope ${ }^{2} \mathrm{H}_{5}$-glycerol. There was no evidence that treatment with subpressor or pressor dosages of Ang II produced a significant alteration in lipolytic activity. Moreover, blockade of the RAS with an ACE inhibitor was equally unremarkable in its effects on whole-body lipolysis (117). In summary, studies that examined the effect of Ang II on lipolysis are controversial and therefore further investigation is required to establish the influence of Ang II on lipolysis.

\section{Ang II-induced effects on body weight}

Results of the effect of Ang II on body weight are controversial. In line with a potential trophic role of Ang II in adipose tissue, AGT-deficient mice showed an impaired diet-induced weight gain (118). Furthermore, studies in rats and humans have demonstrated weight loss with the administration of ACE inhibitors (119122), suggesting a role of Ang II in weight gain. In addition, convincing evidence that the RAS is involved in adipose tissue development was found both in wildtype mice in which adipose AGT was overexpressed and in AGT-knockout mice in which AGT expression was restored into adipose tissue. In both genotypes, targeted expression of AGT in adipose tissue elevated fat mass (75). Interestingly, the AGT-knockout mice whose AGT expression was restored into adipose tissue had AGT in the circulation as compared with AGT-deficient mice, in which AGT was undetectable in the plasma, and had a higher blood pressure than the AGTdeficient mice. In line with this, wild-type mice that overexpressed AGT in adipose tissue had increased concentrations of circulating AGT, compared with wild-type mice, and were hypertensive. This suggests that a genetically determined high-AGT expression in adipose tissue could result in an increased local adipose tissue development. Furthermore, because obese subjects may have an increased AGT expression in adipose tissue, as discussed earlier, AGT production by adipose tissue may be elevated in these subjects, possibly resulting in a positive feedback 
loop that stimulates further development of adipose tissue. In addition, AGT produced by adipose tissue of obese subjects may be of importance in the endocrine system, supporting a role of adipose tissue-derived AGT in hypertensive obese subjects.

However, Ang II may also be a protective factor against expansion of adipose tissue. For example, chronic Ang II infusion in rats has been shown to result in weight loss (123-125) and reduction of white adipose tissue mass (124). Possible explanations for this weight loss have been suggested to be activation of the sympathetic nervous system, a reduced food intake, changes in plasma leptin concentration and an increase in body temperature (124).

\section{Ang II-induced effects on glucose metabolism}

In addition to the possible link between Ang II and fat metabolism, there is also evidence that Ang II could have an effect on glucose metabolism. In aortic smooth muscle cells, Ang II appears to inhibit insulin-dependent activation of PI3-kinase, a major pathway for insulin signal transduction, and therefore decreases the ability of the cell to take up glucose in response to insulin (126). The exact mechanism causing this inhibition is unclear, but Ang II phosphorylates a number of proteins, including the insulin receptor (IR) $\beta$-subunit, IR substrate-1 (IRS-1) and/or PI3kinase, and inhibits the insulin-stimulated association between IRS-1 and the regulatory p 85 subunit of PI3-kinase by $30-50 \%$ in a dose-dependent manner (126, 127). These findings suggest that activation of the RAS may contribute to insulin resistance in Ang II-responsive tissues.

In line with these findings, it has been demonstrated that both acute and chronic $A T_{1}$ receptor antagonism reduces insulin resistance in obese Zucker rats (128). The effect of chronic Ang II receptor antagonism on skeletal muscle glucose uptake was associated with an increase in GLUT4 protein expression in these rats (128). In addition, an improved insulin action on peripheral glucose disposal has been shown with ACE inhibitor treatment in animal models (129, 130) and clinical investigations (131-136). Furthermore, randomized trials have demonstrated that ACE inhibitors improve insulin sensitivity, may prevent the development of type 2 diabetes mellitus and reduce the incidence of diabetes-related end points $(132,137$ 140). In contrast, no reduction in progression to diabetes on ACE inhibitor therapy has been reported (141). Because body weight was measured only at baseline in these studies, we cannot exclude the possibility that the effect of ACE inhibitor treatment on insulin sensitivity observed in these studies was a result of a reduction in body weight. Bradykinin accumulation caused by ACE inhibitor 
treatment $(142,143)$ could also play an important role in this case. It has been demonstrated that bradykinin independently induces GLUT4 translocation in dog adipocytes (144) and increases basal and insulin-stimulated glucose uptake in the skeletal muscles of insulin resistant obese Zucker rats $(145,146)$, possibly by improving post-receptor insulin signalling and enhancing GLUT4 translocation to the cell membrane (146). Furthermore, in accordance with the possible insulin antagonism of Ang II, it has been shown that Ang II acutely increases gluconeogenesis $(147,148)$ and liver glycogenolysis $(149,150)$. In summary, several lines of evidence suggest that Ang II may contribute to the impairment in insulin sensitivity associated with obesity and type 2 diabetes mellitus.

\section{Conchusions}

Although in vivo Ang II generation in human adipose tissue has not been shown yet, there is evidence for the existence of a local adipose tissue RAS. It has been demonstrated that several components of the RAS are positively correlated with BMI in humans. Therefore, obese subjects may secrete more Ang II from adipose tissue than lean individuals. Because the RAS is a major determinant of blood pressure, Ang II secreted from adipose tissue could be an important link between obesity and obesity-related hypertension. Although the mechanisms remain to be clarified, Ang II has been shown to be involved in adipocyte growth and differentiation. Furthermore, Ang II may decrease ATBF and therefore affect metabolism. In this case, a diminished ATBF could lead to a reduced adipose tissue lipolysis, thereby increasing fat storage in adipose tissue. The direct effects of Ang II on adipose tissue lipolysis are not yet clear and require further investigation. The same puzzling picture applies for the Ang II-induced effect on body weight. Finally, Ang II may interfere with the insulin signalling cascade, leading to a reduced glucose uptake. Because of these potential effects, Ang II may play an important role in the pathophysiology of obesity and obesity-related disorders, including hypertension and type 2 diabetes mellitus.

\section{Pharmacotherapeutic implications}

Over the last decade, an impressive amount of knowledge has been obtained about the RAS. As discussed in the previous section, Ang II may play a role in the pathophysiology of obesity and obesity-related disorders, such as hypertension and type 2 diabetes mellitus. Because of the likely elevated generation of Ang II in adipose tissue of obese subjects and the potential effects of Ang II, it might be 
beneficial to inhibit the production and/or actions of Ang II in obese subjects. Until now, two different types of drugs that interfere with the RAS have been developed, primarily for the treatment of hypertension and cardiovascular diseases. Firstly ACE inhibitors, reducing the production of Ang II, have been widely used for the treatment of hypertension. There is strong evidence that this type of drug improves cardiac function and prolongs survival in patients with heart failure (137, 151-156). As the Ang II receptors have been identified, a second type of drug that antagonizes these receptors has been developed. Because most of the known effects of Ang II are mediated through the $A T_{1}$ receptor (26), the discovery of drugs that selectively bind to the $A T_{1}$ receptor subtype, the $A T_{1}$ receptor antagonists, has represented an important step towards better control of cardiovascular diseases and prevention of cardiovascular end points (157-160). In this section, we will focus on the advantages and disadvantages of the pharmacological use of $A C E$ inhibitors and $A T_{1}$ antagonists and highlight the possible implications of these drugs in the treatment of obesity-related disorders.

\section{Pharmacological differences between $A C E$ inhibitors and $A T_{1}$ receptor antagonists}

It is a very important clinical question whether $A T_{1}$ receptor antagonists have different pharmacological actions compared with ACE inhibitors. In addition to decreasing the production of Ang II, ACE inhibitors cause accumulation of bradykinin by inhibiting its degradation, because ACE is one of the enzymes physiologically involved in bradykinin degradation $(142,143)$. It has been reported that bradykinin contributes to ACE inhibitor-induced vasodilatation $(161,162)$ and is partially responsible for the hypotensive effects of ACE inhibitors $(143,163)$. In line with these findings, it has been demonstrated that bradykinin stimulates the NO/cGMP system in a paracrine manner $(164,165)$ to promote vasodilatation (161) (figure 2.4). Therefore, ACE inhibitors may also induce vasodilatation in adipose tissue, thereby increasing ATBF and affecting metabolism. Bradykinin not only causes vasodilatation, but may also increase glucose uptake (144-146) as discussed earlier in this review. Thus, ACE inhibitors may have substantial beneficial effects in obesity and type 2 diabetes mellitus by improving insulin sensitivity through bradykinin accumulation.

Accumulation of bradykinin does not occur when using $A T_{1}$ antagonists. On the other hand, $A T_{1}$ receptor antagonists are able to induce a certain blockade of the $\mathrm{AT}_{1}$ receptor. Chronic $\mathrm{AT}_{1}$ antagonist therapy results in an increased Ang II 


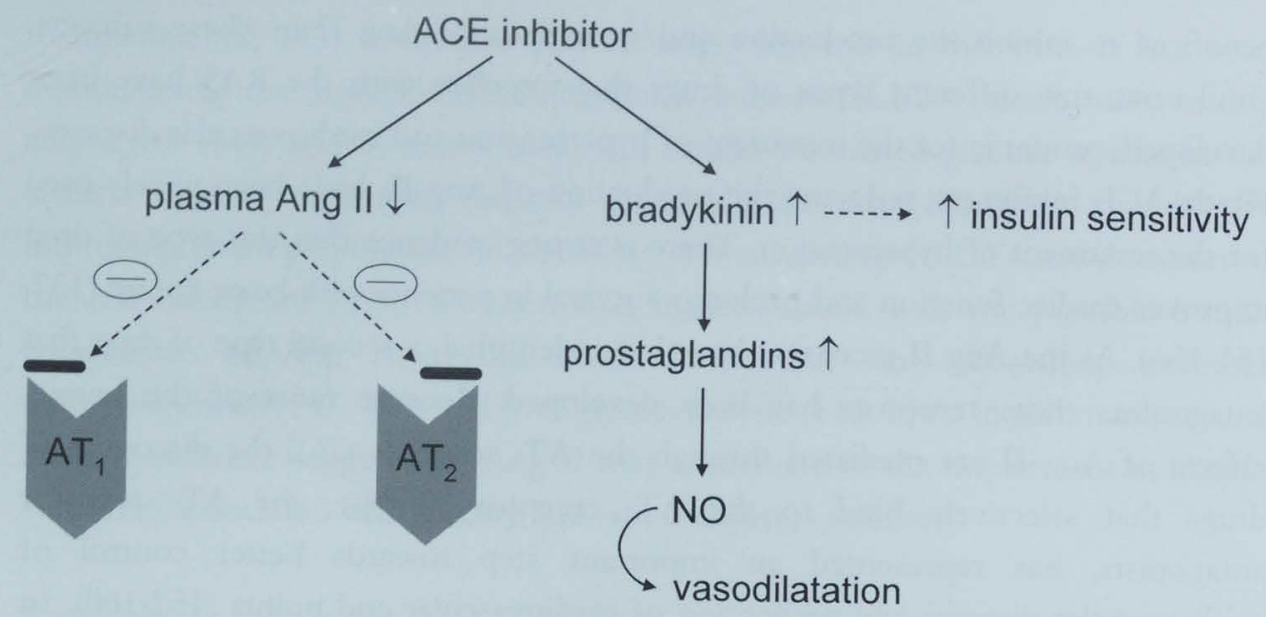

Figure 2.4 The potential effects of ACE inhibitor therapy. ACE, angiotensin-converting enzyme; Ang II, angiotensin II; NO, nitric oxide; $\mathrm{AT}_{1}$, angiotensin type 1 receptor; $\mathrm{AT}_{2}$, angiotensin type 2
receptor.

concentration because of blockade of the negative feedback mechanism of renin release (166). The elevated Ang II concentration may compete with the $\mathrm{AT}_{1}$ receptor antagonist, thereby attenuating the $\mathrm{AT}_{1}$ receptor antagonist-induced inhibition of the $A T_{1}$ receptor. However, stimulation of the $A T_{2}$ receptor is probably increased at the same time, because increased Ang II may act preferably on the $\mathrm{AT}_{2}$ receptor (167) (figure 2.5). Thus, in addition to the potential beneficial effects of bradykinin accumulation on blood flow and insulin sensitivity with ACE inhibitor treatment, a more pronounced stimulation of the $\mathrm{AT}_{2}$ receptor with $\mathrm{AT}_{1}$ receptor antagonist therapy might play an important role in the pharmacological differences between these types of drugs in the treatment of obesity-related disorders, such as hypertension and type 2 diabetes mellitus.

\section{Effects of $A T_{2}$ receptor activation}

It has been shown that activation of the $\mathrm{AT}_{2}$ receptor exerts antagonistic effects against $\mathrm{AT}_{1}$ receptor stimulation by inducing vasodilatation and apoptosis and by inhibiting cell growth and proliferation $(20,32,40,43,44,47,48,168)$. This supports the concept that activation of the $\mathrm{AT}_{2}$ receptor may have beneficial effects in obesity by inducing vasodilatation in adipose tissue, thereby increasing $\mathrm{ATBF}$. Furthermore, there is strong evidence that activation of the $\mathrm{AT}_{2}$ receptor 


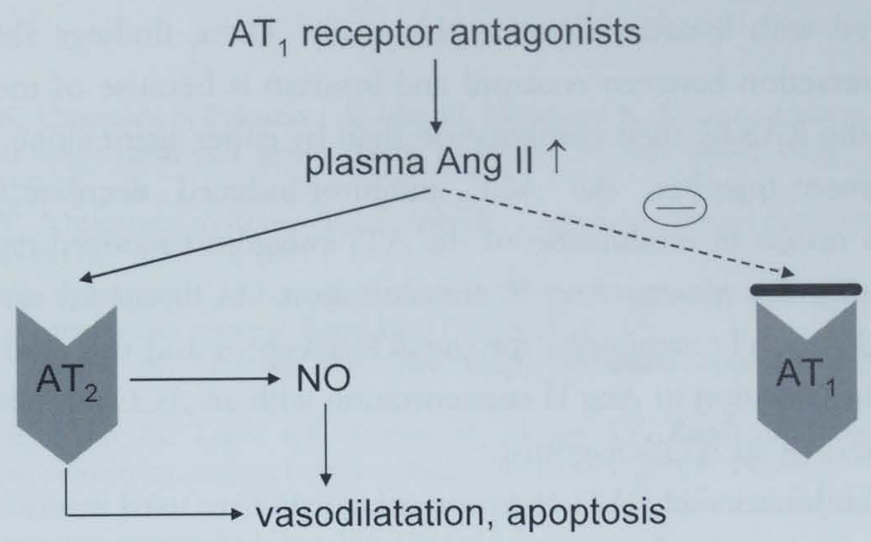

Figure 2.5 The potential effects of $\mathrm{AT}_{\mathrm{l}}$ antagonist therapy. NO, nitric oxide; Ang II, angiotensin II; $\mathrm{AT}_{1}$, angiotensin type 1 receptor; $\mathrm{AT}_{2}$, angiotensin type 2 receptor.

has beneficial effects in people with cardiovascular diseases (169-174), but some conflicting data have also been reported (175-177). However, the effects of Ang II acting through the $\mathrm{AT}_{2}$ receptor on adipocyte growth and proliferation are not yet clear. Obviously, before any conclusions can be drawn about the possibility of $\mathrm{AT}_{2}$ receptor-selective ligand treatment in obesity and obesity-related hypertension, the exact physiological role of the $\mathrm{AT}_{2}$ receptor in health and disease states has to be elucidated.

\section{Combination therapy}

The rationale behind combination therapy with an ACE inhibitor and an $\mathrm{AT}_{1}$ receptor antagonist is a more potent blockade of the RAS. This could be more effective for attenuating the potential deleterious Ang II-induced effects than monotherapy with one of these agents. As expected, combining these two types of drugs induced an additive effect on blood pressure reduction (178).

Although more effective, the aim of combination therapy is not to completely block the RAS. Instead, combination therapy allows to abolish the excess of RAS activity by using low doses of different drugs. For example, it has been shown that a low-dose combination of losartan $\left(3 \mathrm{mg} \cdot \mathrm{kg}^{-1} \cdot \mathrm{d}^{-1}\right.$, single oral dose) and enalapril ( $3 \mathrm{mg} \cdot \mathrm{kg}^{-1} \cdot \mathrm{d}^{-1}$, single oral dose) resulted in more pronounced reductions in blood pressure and cardiac weight in rats than monotherapy with higher doses (10 $\mathrm{mg} \cdot \mathrm{kg}^{-1} \cdot \mathrm{d}^{-1}$, single oral dose) (179). It is very interesting to note that the combination of enalapril with losartan prevented or reduced the increase in Ang II 
levels observed with losartan alone in this study. These findings show that the synergistic interaction between enalapril and losartan is because of more effective inhibition of the RAS by their combination than by either agent alone. When both drugs are given together, the ACE inhibitor-induced decrease in Ang II concentration results in modulation of the $\mathrm{AT}_{1}$ antagonist-induced rise in Ang II, thereby lowering the plasma Ang II concentration. As discussed earlier, Ang II competes with the $\mathrm{AT}_{1}$ antagonist for the $\mathrm{AT}_{1}$ receptor and therefore preventing or reducing the elevation in Ang II concentration with an ACE inhibitor, increases the effectiveness of an $A T_{1}$ antagonist.

Thus, if $\mathrm{ACE}$ inhibitors and $\mathrm{AT}_{1}$ receptor antagonists are used in the treatment of obesity and obesity-related disorders, combination therapy would probably be more effective than monotherapy. However, the potential benefit of the combination of $\mathrm{ACE}$ inhibitors and $\mathrm{AT}_{1}$ antagonists may be partially offset by loss of the $\mathrm{AT}_{2}$ receptor agonism by Ang II. Obviously, long-term studies using a wide range of safe doses are necessary to establish the possible additional beneficial effects of combination therapy to inhibit the RAS.

\section{Conclusions and perspectives}

Several components of the RAS have been demonstrated in different tissues, including adipose tissue, suggesting a local RAS in these tissues. Although the actions of Ang II on metabolism have not been studied widely, it is intriguing to assume that components of the RAS produced by adipocytes may play an autocrine, a paracrine and/or an endocrine tole in the pathophysiology of obesity and provide a potential pathway through which obesity leads to hypertension and type 2 diabetes mellitus. Although Ang I.I may impair glucose uptake, thereby inducing insulin resistance, and reduce ATBF, the effects of Ang II on adipocyte growth and differentiation, adipose tissue lipolysis and body weight are not fully clear and require further investigation. Because the production of Ang II by adipose tissue may be elevated in obese subjects, it would be interesting to establish the metabolic and hemodynamic adaptations after decreasing RAS activity in these subjects. This could be achieved using ACE inhibitors, $\mathrm{AT}_{1}$ receptor antagonists or a combination of both. When our understanding of the involvement of the RAS in obesity, obesity-related hypertension and insulin resistance has increased, and Ang II appears to be of importance in this case, these types of drugs might be used for the treatment of obesity-related disorders. 


\section{References}

1. Tamura $K$, Umemura $S$, Fukamizu $A$, Ishii $M$, Murakami $K$. Recent advances in the study of renin and angiotensinogen genes: from molecules to the whole body. Hypertens Res 1995;18(1):7-18.

2. Inagami T. A memorial to Robert Tiegerstedt: the centennial of renin discovery. Hypertension 1998;32(6):953-7.

3. Phillips MI, Speakman EA, Kimura B. Levels of angiotensin and molecular biology of the tissue renin angiotensin systems. Regul Pept 1993;43(1-2):1-20.

4. Reid IA, Morris BJ, Ganong WF. The renin-angiotensin system. Annu Rev Physiol 1978;40:377-410.

5. Dorer FE, Kahn JR, Lentz KE, Levine M, Skeggs LT. Purification and properties of angiotensin-converting enzyme from hog lung. Circ Res 1972;31(3):356-66.

6. Skeggs LT, Lentz KE, Gould $\lambda \mathrm{B}$, Hochstrasser H, Kahn JR. Biochemistry and kinetics of the renin-angiotensin system. Fed Proc 1967;26(1):42-7.

7. Tumer $\mathrm{AJ}$, Hooper NM. The angiotensin-converting enzyme gene family: genomics and pharmacology. Trends Pharmacol Sci 2002;23(4):177-83.

8. Hollenberg NK, Fisher ND, Price DA. Pathways for angiotensin II generation in intact human tissue: evidence from comparative pharmacological interruption of the renin system. Hypertension 1998;32(3):387-92.

9. Shiota N, Okunishi H, Takai S, Mikoshiba I, Sakonjo H, Shibata N, et al. Tranilast suppresses vascular chymase expression and neointima formation in balloon-injured dog carotid artery. Circulation 1999;99(8):1084-90.

10. Wolny A, Clozel JP, Rein J, Mory P, Vogt P, Turino M, et al. Functional and biochemical analysis of angiotensin IJ-forming pathways in the human heart. Circ Res 1997;80(2):219-27.

11. Urata $H$, Nishimura $H$, Ganten D. Chymase-dependent angiotensin II forming systems in humans. Am J Hypertens 1996;9(3):277-84.

12. Urata H, Boehm KD, Philip A, Kinoshita A, Gabrovsek J, Bumpus FM, et al. Cellular localization and regional distribution of an angiotensin II- forming chymase in the heart. J Clin Invest 1993;91(4):1269-81.

13. Urata $H$, Kinoshita $A$, Misono KS, Bumpus FM, Husain A. Identification of a highly specific chymase as the major angiotensin II- forming enzyme in the human heart. J Biol Chem 1990;265(36):22348-57.

14. Whitebread S, Mele M, Kamber B, de Gasparo M. Preliminary biochemical characterization of two angiotensin II receptor subtypes. Biochem Biophys Res Commun 1989;163(1):284-91.

15. Chiu AT, Herblin WF, McCall DE, Ardecky RJ, Carini DJ, Duncia JV, et al. Identification of angiotensin II receptor subtypes. Biochem Biophys Res Commun 1989;165(1):196-203.

16. Chaki S, Inagami T. Identification and characterization of a new binding site for angiotensin II in mouse neuroblastoma neuro-2A cells. Biochem. Biophys Res Commun 1992;182(1):388-94.

17. Swanson GN, Hanesworth JM, Sardinia MF, Coleman JK, Wright JW, Hall KL, et al. Discovery of a distinct binding site for angiotensin II (3-8), a putative angiotensin IV receptor. Regul Pept 1992;40(3):409-19

18. Unger T, Chung O, Csikos T, Culman J, Gallinat S, Gohlke P, et al. Angiotensin receptors. J Hypertens Suppl 1996;14(5):S95-103.

19. Brown L, Sernia C. Angiotensin receptors in cardiovascular diseases. Clin Exp Pharmacol Physiol 1994;21(10):811-8.

20. Matsubara H. Pathophysiological role of angiotensin II type 2 receptor in cardiovascular and renal diseases. Circ Res 1998;83(12):1182-91.

21. Inagami $\mathrm{T}$. Recent progress in molecular and cell biological studies of angiotensin receptors. Curr Opin Nephtol Hypertens 1995;4(1):47-54

22. de Gasparo M, Husain A, Alexander W, Catt KJ, Chiu AT, Drew M, et al. Proposed update of angiotensin receptor nomenclature. Hypertension 1995;25(5):924-7.

23. Iwai $\mathrm{N}$, Inagami $\mathrm{T}$. Identification of two subtypes in the rat type I angiotensin II receptor. FEBS Lett 1992;298(2-3):257-60. 
24. Allen $A M$, Zhuo J, Mendelsohn FA. Localization and function of angiotensin $A T_{1}$ receptors. Am J Hypertens 2000;13(1 Pt 2):31S-38S.

25. Engeli S, Negrel R, Sharma AM. Physiology and pathophysiology of the adipose tissue reninangiotensin system. Hypertension 2000;35(6):1270-7.

26. Timmermans PB, Wong PC, Chiu AT, Herblin WF, Benfield P, Carini DJ, et al. Angiotensin II receptors and angiotensin II receptor antagonists. Pharmacol Rev 1993;45(2):205-51.

27. English V, Cassis L. Facilitation of sympathetic neutotransmission contributes to angiotensin regulation of body weight. J Neural Transm 1999;106(7-8):631-44.

28. Muller DN, Dechend R, Mervaala EM, Park JK, Schmidt F, Fiebeler A, et al. NF-kappaB inhibition ameliorates angiotensin II-induced inflammatory damage in rats. Hypertension 2000;35(1 Pt 2):193-201.

29. Nakamura S, Nakamura I, Ma L, Vaughan DE, Fogo AB. Plasminogen activator inhibitor-1 expression is regulated by the angiotensin type 1 receptor in vivo. Kidney Int 2000;58(1):251-9.

30. Vaughan DE, Lazos SA, Tong K. Angiotensin II regulates the expression of plasminogen activator inhibitor-1 in cultured endothelial cells. $A$ potential link between the reninangiotensin system and thrombosis. J Clin Invest 1995;95(3):995-1001.

31. Chung $O$, Stoll $M$, Unger $T$. Physiologic and pharmacologic implications of $A T_{1}$ versus $A T_{2}$ receptors. Blood Press Suppl 1996;2:47-52.

32. Nakajima M, Hutchinson HG, Fujinaga M, Hayashida W, Morishita R, Zhang L, et al. The angiotensin II type $2\left(\mathrm{AT}_{2}\right)$ receptor antagonizes the growth effects of the $\mathrm{AT} \mathrm{T}_{1}$ receptor: gainof-function study using gene transfer. Proc Natl Acad Sci U S A 1995;92(23):10663-7.

33. Berry C, Hamilton CA, Brosnan M], Magill FG, Berg GA, McMurray JJ, et al. Investigation into the sources of superoxide in human blood vessels: angiotensin II increases superoxide production in human internal mammaty arteries. Circulation 2000;101(18):2206-12.

34. Rajagopalan S, Kurz S, Munzel T, Tarpey M, Freeman BA, Griendling KK, et al. Angiotensin II-mediated hypertension in the rat increases vascular superoxide production via membrane $\mathrm{NADH} / \mathrm{NADPH}$ oxidase activation. Contribution to alterations of vasomotor tone. J Clin Invest 1996;97(8):1916-23.

35. Griendling $\mathrm{KK}$, Minieri $\mathrm{CA}$, Ollerenshaw JD, Alexander RW. Angiotensin II stimulates $\mathrm{NADH}$ and NADPH oxidase activity in cultured vascular smooth muscle cells. Circ Res 1994;74(6):1141-8.

36. Berry C, Touyz R, Dominiczak AF, Webb RC, Johns DG. Angiotensin receptors: signaling, vascular pathophysiology, and interactions with ceramide. Am J Physiol Heart Circ Physiol 2001;281(6):H2337-65.

37. Touyz RM, Schiffrin EL. Signal ttansduction mechanisms mediating the physiological and pathophysiological actions of angiotensin II in vascular smooth muscle cells. Pharmacol Rev 2000;52(4):639-72.

38. Mukoyama M, Nakajima M, Horiuchi M, Sasamura H, Pratt RE, Dzau VJ. Expression cloning of type 2 angiotensin II receptor reveals a unique class of seven-transmembrane receptors. J Biol Chem 1993;268(33):24539-42.

39. Zhang J, Pratt RE. The $A T_{2}$ receptor selectively associates with Gialpha2 and Gialpha3 in the rat fetus. J Biol Chem 1996;271(25):15026-33.

40. Hayashida W, Horiuchi M, Dzau VJ. Intracellular third loop domain of angiotensin II type-2 receptor. Role in mediating signal transduction and cellular function. J Biol Chem 1996;271(36):21985-92.

41. Buisson B, Laflamme L, Bottari SP, de Gasparo M, Gallo-Payet N, Payet MD. A G protein is involved in the angiotensin $A T_{2}$ receptor inhibition of the $T$-type calcium current in nondifferentiated NG108-15 cells. J Biol Chem 1995;270(4):1670-4.

42. Shanmugam S, Corvol P, Gasc JM. Angiotensin II type 2 receptor mRNA expression in the developing cardiopulmonary system of the rat. Hypertension 1996;28(1):91-7.

43. Siragy HM. The role of the $A T_{2}$ receptor in hypertension. Am J Hypertens $2000 ; 13(5 \mathrm{Pt}$ 2):62S-67S.

44. Gallinat $S$, Busche $S$, Raizada MK, Sumners $C$. The angiotensin II type 2 receptor: an enigma with multiple variations. Am J Physiol Endocrinol Metab 2000;278(3):E357-74. 
45. Horiuchi M, Lehtonen JY, Daviet L. Signaling Mechanism of the $A T_{2}$ Angiotensin II Receptor: Crosstalk between $A T_{1}$ and $A T_{2}$ Receptors in Cell Growth. Trends Endocrinol Metab 1999;10(10):391-396.

46. Unger $\mathrm{T}$. The angiotensin type 2 receptor: variations on an enigmatic theme. J Hypertens 1999;17(12 Pt 2):1775-86.

47. Horiuchi $M$, Yamada $T$, Hayashida W, Dzau VJ. Interferon regulatory factor-1 up-regulates angiotensin II type 2 receptor and induces apoptosis. J Biol Chem 1997;272(18):11952-8.

48. Horiuchi M, Hayashida W, Kambe T, Yamada T, Dzau VJ. Angiotensin type 2 receptor dephosphorylates $\mathrm{Bcl}-2$ by activating mitogen-activated protein kinase phosphatase-1 and induces apoptosis. J Biol Chem 1997;272(30):19022-6.

49. Riordan JF. Angiotensin II: biosynthesis, molecular recognition, and signal transduction. Cell Mol Neurobiol 1995;15(6):637-51.

50. Chai SY, Zhuo J, Mendelsohn FA. Localization of components of the renin-angiotensin system and site of action of inhibitors. Arzneimittelforschung 1993;43(2A):214-21.

51. Dostal DE, Rothblum KN, Chernin MI, Cooper GR, Baker KM. Intracardiac detection of angiotensinogen and renin: a localized renin- angiotensin system in neonatai rat heart. Am J Physiol 1992;263(4 Pt 1):C838-50.

52. Mulrow PJ. Adrenal renin: regulation and function. Front Neuroendocrinol 1992;13(1):47-60.

53. Dzau VJ, Ellison KE, Brody T, Ingelfinger J, Pratt RE. A comparative study of the distributions of renin and angiotensinogen messenger ribonucleic acids in rat and mouse tissues. Endocrinology 1987;120(6):2334-8.

54. Murakami E, Eggena P, Barrett JD, Sambhi MP. Heterogeneity of renin substrate released from hepatocytes and in brain extracts. Life Sci 1984;34(4):385-92.

55. Paul M, Wagner J, Dzau VJ. Gene expression of the renin-angiotensin system in human tissues. Quantitative analysis by the polymerase chain reaction. J Clin Invest 1993;91(5):205864.

56. Schling P, Mallow $\mathrm{H}$, Trind A, Loffler $\mathrm{G}$. Evidence for a local renin angiotensin system in primary cultured human preadipocytes. Int J Obes Relat Metab Disord 1999;23(4):336-41.

57. Karlsson C, Lindell K, Ottosson M, Sjostrom L, Carlsson B, Carlsson LM. Human adipose tissue expresses angiotensinogen and enzymes required for its conversion to angiotensin II. J Clin Endocrinol Metab 1998;83(11):3925-9.

58. Jones BH, Standridge MK, Taylor JW, Moustaid N. Angiotensinogen gene expression in adipose tissue: analysis of obese models and hormonal and nutritional control. Am J Physiol 1997;273(1 Pt 2):R236-42.

59. Jonsson JR, Game PA, Head RJ, Frewin DB. The expression and localisation of the angiotensin-converting enzyme mRNA in human adipose tissue. Blood Press 1994;3(1-2):72-5.

60. Crandall DL, Herzlinger HE, Saunders BD, Zolotor RC, Feliciano L, Cervoni P. Identification and characterization of angiotensin II receptors in rat epididymal adipocyte membranes. Metabolism 1993;42(4):511-5.

61. Cassis LA, Saye J, Peach MJ. Location and regulation of rat angiotensinogen messenger RNA. Hypertension 1988;11(6 Pt 2):591-6.

62. Danser AH. Local renin-angiotensin systems. Mol Cell Biochem 1996;157(1-2):211-6.

63. Unger $T$, Gohlke P. Tissue renin-angiotensin systems in the heart and vasculature: possible involvement in the cardiovascular actions of converting enzyme inhibitors. Am J Cardiol 1990;65(19):3I-10I.

64. Dzau VJ. Circulating versus local renin-angiotensin system in cardiovascular homeostasis. Circulation 1988;77(6 Pt 2):14-13.

65. Cooper R, Forrester T, Ogunbiyi O, Muffinda J. Angiotensinogen levels and obesity in four black populations. ICSHIB Investigators. J Hypertens 1998;16(5):571-5.

66. Cooper R, McFarlane-Anderson N, Bennett FI, Wilks R, Puras A, Tewksbury D, et al. ACE, angiotensinogen and obesity: a potential pathway leading to hypertension. J Hum Hypertens 1997;11(2):107-11.

67. Umemura S, Nyri N, Tamura K, Hibi K, Yamaguchi S, Nakamaru M, et al. Plasma angiotensinogen concentrations in obese patients. Am J Hyperteins 1997;10(6):629-33. 
68. Bloem LJ, Manatunga AK, Tewksbury DA, Pratt JH. The serum angiotensinogen concentration and variants of the angiotensinogen gene in white and black children. $J$ Clin Invest 1995;95(3):948-53.

69. Licata G, Scaglione R, Ganguzza A, Corrao S, Donatelli M, Parrinello G, et al. Central obesity and hypertension. Relationship between fasting serum insulin, plasma renin activity, and diastolic blood pressure in young obese subjects. Am J Hypertens 1994;7(4 Pr 1):314-20.

70. Egan BM, Stepniakowski K, Goodfriend TL. Renin and aldosterone are higher and the hyperinsulinemic effect of sait restriction greater in subjects with risk factors clustering. Am J Hypertens 1994;7(10 Pt 1):886-93.

71. van Harmelen V, Ariapart P, Hoffstedt J, Lundkvist I, Bringman S, Arner P. Increased adipose angiotensinogen gene expression in human obesity. Obes Res 2000;8(4):337-41.

72. van Harmelen V, Elizalde M, Ariapart P, Bergstedt-Lindqvist S, Reynisdottir S, Hoffstedt J, et al. The association of human adipose angiotensinogen gene expression with abdominal fat distribution in obesity. Int J Obes Relat Metab Disord 2000;24(6):673-8.

73. Giacchetti G, Faloia E, Sardu C, Camilloni MA, Mariniello B, Gatti C, et al. Gene expression of angiotensinogen in adipose tissue of obese patients. Int $\mathrm{J}$ Obes Relat Metab Disord 2000;24:S142-3.

74. Hainault I, Nebout G, Turban S, Ardouin B, Ferre P, Quignard-Boulange A. Adipose tissuespecific increase in angiotensinogen expression and secretion in the obese $(\mathrm{fa} / \mathrm{fa})$ Zucker rat. Am J Physiol Endocrinol Metab 2002;282(1):E59-66.

75. Massiera F, Bloch-Faure M, Ceiler D, Murakami K, Fukamizu A, Gasc JM, et al. Adipose angiotensinogen is involved in adipose tissue growth and blood pressure regulation. Faseb J 2001;15(14):2727-9.

76. Sjostrom CD, Lissner L, Sjostrom L. Relationships between changes in body composition and changes in cardiovascular risk factors: the SOS Intervention Study. Swedish Obese Subjects. Obes Res 1997;5(6):519-30.

77. Alonso-Galicia M, Brands MW, Zappe DH, Hall JE. Hypertension in obese Zucker rats. Role of angiotensin II and adrenergic activity. Hypertension 1996;28(6):1047-54.

78. Frederich RC, Jr., Kahn BB, Peach MJ, Flier JS. Tissue-specific nutritional regulation of angiotensinogen in adipose tissue. Hypertension 1992;19(4):339-44.

79. Safonova I, Aubert J, Negrel R, Ailhaud G. Regulation by fatty acids of angiotensinogen gene expression in preadipose cells. Biochem J 1997;322(Pt 1):235-9.

80. Aubert J, Safonova I, Negrel R, Ailhaud G. Insulin down-regulates angiotensinogen gene expression and angiotensinogen secretion in cultured adipose cells. Biochem Biophys Res Commun 1998;250(1):77-82.

81. Dostal DE, Booz GW, Baker KM. Regulation of angiotensinogen gene expression and protein in neonatal rat cardiac fibroblasts by glucocorticoid and beta-adrenetgic stimulation. Basic Res Cardiol 2000;95(6):485-90.

82. Jikihara $\mathrm{H}$, Handwerger $\mathrm{S}$, Poisner AM. Beta-adrenergic regulation of renin expression in differentiated U-937 monocytic cells. Biochem Pharmacol 1997;53(12):1883-8.

83. Hsuch WA, Goldstone R, Carlson EJ, Horton R. Evidence that the beta-adrenergic system and prostaglandins stimulate tenin telease through different mechanisms. J Clin Endocrinol Metab 1985;61(3):399-403.

84. Pettinger WA, Mitchell HC. Renin release, saralasin and the vasodilator-beta-blocker drug interaction in man. N Engl J Med 1975;292(23):1214-7.

85. Ramsay DJ. Beta-adrenergic thirst and its relation to the renin-angiotensin system. Fed Proc 1978;37(13):2689-93.

86. Sinaiko AR. Influence of adrenergic nervous and prostaglandin systems on hydralazineinduced renin release. Life Sci 1983;33(23):2269-75.

87. Ueda H. Renin and nervous system. Jpn Heart J 1976;17(4):521-6.

88. Zayas VM, Blumenfeld JD, Bading B, McDonald M, James GD, Lin YF, et al. Adrenergic regulation of renin secretion and renal hemodynamics during deliberate hypotension in humans. Am J Physiol 1993;265(5 Pt 2):F686-92.

89. Nakamaru M, Jackson EK, Inagami T. Role of vascular angiotensin II released by betaadrenergic stimulation in rats. J Cardiovasc Pharmacol 1986;8(Suppl 10):S1-5. 
90. Pratt JH, McAteer JA. Beta-adrenergic enhancement of angiotensin II-stimulated aldosterone secretion. Life Sci 1989;44(26):2089-95.

91. Sil P, Sen S. Angiotensin II and myocyte growth: role of fibroblasts. Hypertension 1997;30(2 Pt 1):209-16.

92. Ailhaud G, Fukamizu A, Massiera F, Negtel R, Saint-Marc P, Teboul M. Angiotensinogen, angiotensin II and adipose tissue development. Int J Obes Relat Metab Disord 2000;24:S33-5.

93. Crandall DL, Armellino DC, Busler DE, McHendry-Rinde B, Kral JG. Angiotensin II receptors in human preadipocytes: role in cell cycle regulation. Endocrinology 1999;140(1):1548.

94. Lyle RE, Habener JF, McGehee RE, Jr. Antisense oligonucleotides to differentiation-specific element binding protein (DSEB) mRNA inhibit adipocyte differentiation. Biochem Biophys Res Commun 1996;228(3):709-15.

95. Darimont C, Vassaux G, Ailhaud G, Negrel R. Differentiation of preadipose cells: paracrine role of prostacyclin upon stimulation of adipose cells by angiotensin-II. Endocrinology 1994;135(5):2030-6.

96. Richelsen B. Prostaglandins in adipose tissue--with special reference to triglyceride metabolism. Dan Med Bull 1991;38(3):228-44.

97. Hyman BT, Stoll LL, Spector AA. Prostaglandin production by 3T3-L1 cells in culture. Biochim Biophys Acta 1982;713(2):375-85.

98. Negrel R, Ailhaud G. Metabolism of arachidonic acid and prostaglandin synthesis in the preadipocyte clonal line ob17. Biochem Biophys Res Commun 1981;98(3):768-77.

99. Negrel R. Prostacyclin as a critical prostanoid in adipogenesis. Prostaglandins Leukot Essent Fatty Acids 1999;60(5-6):383-6.

100. Vassaux G, Gaillard D, Ailhaud G, Negrel R. Prostacyclin is a specific effector of adipose cell differentiation. Its dual role as a cAMP- and $\mathrm{Ca}(2+)$-elevating agent. J Biol Chem 1992;267(16):11092-7.

101. Catalioto RM, Gaillard D, Maclouf J, Ailhaud G, Negrel R. Autocrine control of adipose cell differentiation by prostacyclin and PGF2 alpha. Biochim Biophys Acta 1991;1091(3):364-9.

102. Gaillard D, Negrel R, Lagarde M, Ailhaud G. Requirement and role of arachidonic acid in the differentiation of pre- adipose cells. Biochem J 1989;257(2):389-97.

103. Negtcl R, Gaillard D, Ailhaud G. Prostacyclin as a potent effector of adipose-cell differentiation. Biochem J 1989;257(2):399-405.

104. Axelrod L, Minnich AK, Ryan CA. Stimulation of prostacyclin production in isolated rat adipocytes by angiotensin II, vasopressin, and bradykinin: evidence for two separate mechanisms of prostaglandin synthesis. Endocrinology 1985;116(6):2548-53.

105. Darimont C, Vassaux G, Gaillard D, Ailhaud G, Negrel R. In situ microdialysis of prostaglandins in adipose tissue: stimulation of prostacyclin release by angiotensin II. Int J Obes Relat Metab Disord 1994;18(12):783-8.

106. Jones BH, Standridge MK, Moustaid N. Angiotensin II increases lipogenesis in 3T3-L1 and human adipose cells. Endocrinology 1997;138(4):1512-9.

107. Kim S, Dugail I, Standridge M, Claycombe K, Chun J, Moustaid-Moussa N. Angiotensin IIresponsive element is the insulin-responsive element in the adipocyte fatty acid synthase gene: role of adipocyte determination and differentiation factor $1 /$ sterol-regulatory-element-binding protein 1c. Biochem J 2001;357(Pt 3):899-904.

108. Janke J, Engeli S, Gorzelniak K, Luft FC, Sharma AM. Mature adipocytes inhibit in vitro differentiation of human preadipocytes via angiotensin type 1 receptors. Diabetes 2002;51(6):1699-707.

109. Schling $P$, Lofflet $G$. Effects of angiotensin II on adipose conversion and expression of genes of the renin-angiotensin system in human preadipocytes. Horm Mctab Res 2001;33(4):189-95.

110. Boschmann M, Ringel J, Klaus S, Sharma AM. Metabolic and hemodynamic response of adipose tissue to angiotensin II. Obes Res 2001;9(8):486-91.

111. Lönnroth P, Smith U. Intermediary metabolism with an emphasis on lipid metabolism, adipose tissue, and fat cell metabolism: a review. In: Björntorp P, Brodoff BN, editors. Obesity. Philadelphia: JB Lippincott Co; 1992. p. pp 3-14.

112. Blaak EE. Lipolysis in adipose tissue and skeletal muscle: what to be learned from stable isotopes. Int J Obes Relat Metab Disord 2002;26(1):s227. 
113. Samra JS, Clark ML, Humpreys SM, Bannister PA, Summers LKM, Macdonald IA, et al. Evidence for glycerol uptake by adipose tissue. Proceedings of nutrition society 1999;58:164A.

114. Blaak EE, van Baak MA, Kemerink GJ, Pakbiers MT, Heidendal GA, Saris WH. Betaadrenergic stimulation and abdominal subcutaneous fat blood flow in lean, obese, and reducedobese subjects. Metabolism 1995;44(2):183-7.

115. Arner P. Differences in lipolysis between human subcutaneous and omental adipose tissues. Ann Med 1995;27(4):435-8.

116. Leibel RL, Edens NK, Fried SK. Physiologic basis for the control of body fat distribution in humans. Annu Rev Nutr 1989;9:417-43.

117. Townsend RR. The effects of angiotensin-II on lipolysis in humans. Metabolism 2001;50(4):468-72.

118. Massiera F, Seydoux J, Geloen A, Quignard-Boulange A, Turban S, Saint-Marc P, et al. Angiotensinogen-deficient mice exhibit impairment of diet-induced weight gain with alteration in adipose tissue development and increased locomotor activity. Endocrinology 2001;142(12):5220-5.

119. Setoguchi Y, Ohnuki T, Rashid M, Nakamura T, Hattori K, Nagatomo T, et al. Effects of chronic administration of sarpogrelate on systolic blood pressure of spontaneously hypertensive rats: comparison with quinapril. Pharmacology 2002;64(2):71-5.

120. Campbell DJ, Duncan AM, Kladis A, Hatrap SB. Converting enzyme inhibition and its withdrawal in spontaneously hypertensive rats. J Cardiovasc Pharmacol 1995;26(3):426-36.

121. McGrath BP, Matthews PG, Louis W, Howes L, Whitworth JA, Kincaid-Smith PS, et al. Double-blind study of dilevalol and captopril, both in combination with hydrochlorothiazide, in patients with moderate to severe hypertension. J Cardiovasc Pharmacol 1990;16(5):831-8.

122. (UK) EiHSG. Enalapril in essential hypertension: a comparative study with propranolol. $\mathrm{Br} \mathrm{J}$ Clin Pharmacol 1984;18(1):51-6.

123. Harrison-Bernard LM, El-Dahr SS, O'Leary DF, Navar LG. Regulation of angiotensin II type 1 receptor mRNA and protein in angiotensin II-induced hypertension. Hypertension 1999;33(1 Pt 2):340-6.

124. Cassis LA, Marshall DE, Fettinger MJ, Rosenbluth B, Lodder RA. Mechanisms contributing to angiotensin II regulation of body weight. Am J Physiol 1998;274(5 Pt 1):E867-76.

125. Brink M, Wellen J, Delafontaine P. Angiotensin II causes weight loss and decreases circulating insulin- like growth factor $I$ in rats through a pressor-independent mechanism. J Clin Invest 1996;97(11):2509-16.

126. Folli F, Kahn CR, Hansen H, Bouchie JL, Feener EP. Angiotensin II inhibits insulin signaling in aortic smooth muscle cells at multiple levels. $A$ potential tole for serine phosphorylation in insulin/angiotensin II crosstalk. J Clin Invest 1997;100(9):2158-69.

127. Velloso LA, Folli F, Sun XJ, White MF, Saad MJ, Kahn CR. Cross-talk between the insulin and angiotensin signaling systems. Proc Natl Acad Sci U S A 1996;93(22):12490-5.

128. Henriksen EJ, Jacob S, Kinnick TR, Teachey MK, Krekler M. Selective angiotensin II receptor receptor antagonism reduces insulin resistance in obese Zucker rats. Hypertension 2001;38(4):884-90.

129. Jacob S, Henriksen EJ, Fogt DL, Dietze GJ. Effects of trandolapril and verapamil on glucose transport in insulin-resistant rat skeletal muscle. Metabolism 1996;45(5):535-41.

130. Henriksen EJ, Jacob S. Effects of captopril on glucose transport activity in skeletal muscle of obese Zucker rats. Metabolism 1995;44(2):267-72.

131. Vuorinen-Markkola $\mathrm{H}$, Yki-Jarvinen $\mathrm{H}$. Antihypertensive therapy with enalapril improves glucose storage and insulin sensitivity in hypertensive patients with non-insulin-dependent diabetes mellitus. Metabolism 1995;44(1):85-9.

132. Torlone E, Britta M, Rambotti AM, Perriello G, Santeusanio F, Brunetti P, et al. Improved insulin action and glycemic control after long-term angiotensin-converting enzyme inhibition in subjects with arterial hypertension and type II diabetes. Diabetes Care 1993;16(10):1347-55.

133. Paolisso G, Gambardella A, Verza M, D'Amore A, Sgambato S, Varricchio M. ACE inhibition improves insulin-sensitivity in aged insulin-resistant hypertensive patients. J Hum Hypertens $1992 ; 6(3): 175-9$. 
134. Torlone E, Rambotti AM, Perriello G, Botta G, Santeusanio F, Brunetti P, et al. ACEinhibition increases hepatic and extrahepatic sensitivity to insulin in patients with type 2 (noninsulin-dependent) diabetes mellitus and arterial hypertension. Diabetologia 1991;34(2):119-25.

135. Pollare $T$. Insulin sensitivity and blood lipids during antihypertensive treatment with special reference to $A C E$ inhibition. J Diabet Complications 1990;4(2):75-8.

136. Jauch KW, Hartl W, Guenther B, Wicklmayr M, Rett K, Dietze G. Captopril enhances insulin responsiveness of forearm muscle tissue in non-insulin-dependent diabetes mellitus. Eur J Clin Invest 1987;17(5):448-54.

137. Yusuf S, Sleight P, Pogue J, Bosch J, Davies R, Dagenais G. Effects of an angiotensinconverting-enzyme inhibitor, ramipril, on cardiovascular events in high-risk patients. The Heart Outcomes Prevention Evaluation Study Investigators. N Engl ] Med 2000;342(3):14553.

138. Hansson L, Lindholm LH, Niskanen L, Lanke J, Hedner T, Niklason $A$, et al. Effect of angiotensin-converting-enzyme inhibition compared with conventional therapy on cardiovascular morbidity and mortality in hypertension: the Captopril Prevention Project (CAPPP) randomised trial. Lancet 1999;353(9153):611-6.

139. Raccah D, Pettenuzzo-Mollo M, Provendier O, Boucher L, Cozic JA, Gorlier R, et al. Comparison of the effects of captopril and nicardipine on insulin sensitivity and thrombotic profile in patients with hypertension and android obesity. CaptISM Study Group. Captopril Insulin Sensitivity Multicenter Study Group. Am J Hypertens 1994;7(8):731-8.

140. Shieh SM, Sheu WH, Shen DD, Fuh MM, Jeng CY, Jeng JR, et al. Improvement in metabolic risk factors for coronary heart disease associated with cilazapril treatment. $\lambda \mathrm{m}$ J Hypertens 1992;5(8):506-10.

141. Gress TW, Nieto FJ, Shahar E, Wofford MR, Brancati FL. Hypertension and antihypertensive therapy as risk factors for type 2 diabetes mellitus. Atherosclerosis Risk in Communities Study. N Engl J Med 2000;342(13):905-12.

142. Waeber B, Brunner HR. Cardiovascular hypertrophy: role of angiotensin II and bradykinin. J Cardiovasc Pharmacol 1996;27(Suppl 2):S36-40.

143. Linz W, Wiemer G, Gohlke P, Unger T, Scholkens BA. Contribution of kinins to the cardiovascular actions of angiotensin-converting enzyme inhibitors. Pharmacol Rev 1995;47(1):25-49.

144. Isami S, Kishikawa H, Araki E, Uehara M, Kaneko K, Shirotani T, et al. Bradykinin enhances GLUT4 translocation through the increase of insulin receptor tyrosine kinase in primary adipocytes: evidence that bradykinin stimulates the insulin signalling pathway. Diabetologia 1996;39(4):412-20.

145. Henriksen EJ, Jacob S, Kinnick TR, Youngblood EB, Schmit MB, Dietze GJ. ACE inhibition and glucose transport in insulin resistant muscle: roles of bradykinin and nitric oxide. $\mathrm{Am} J$ Physiol 1999;277(1 Pt 2):R332-6.

146. Miyata T, Taguchi T, Uehara M, Isami S, Kishikawa H, Kaneko K, et al. Bradykinin potentiates insulin-stimulated glucose uptake and enhances insulin signal through the bradykinin B2 receptor in dog skeletal muscle and rat L6 myoblasts. Eur J Endocrinol 1998;138(3):344-52.

147. Coimbra CC, Garofalo MA, Foscolo DR, Xavier AR, Migliorini RH. Gluconeogenesis activation after intravenous angiotensin II in freely moving rats. Peptides 1999;20(7):823-7.

148. Whitton PD, Rodrigues LM, Hems DA. Stimulation by vasopressin, angiotensin and oxytocin of gluconeogenesis in hepatocyte suspensions. Biochem J 1978;176(3):893-8.

149. DeWitt LM, Putney JW, Jr. Stimulation of glycogenolysis in hepatocytes by angiotensin II may involve both calcium release and calcium influx. FEBS Lett 1983;160(1-2):259-63.

150. Hems DA, Rodrigues IJM, Whitton PD. Glycogen phosphorylase, glucose output and vasoconstriction in the perfused rat liver. Concentration-dependence of actions of adrenaline, vasopressin and angiotensin II. Biochem J 1976;160(2):367-74.

151. Group I-FISoISC. ISIS-4: a randomised factorial trial assessing early oral captopril, oral mononitrate, and intravenous magnesium sulphate in 58,050 patients with suspected acute myocardial infarction. Lancet 1995;345(8951):669-85.

152. The Acute Infarction Ramipril Efficacy (AIRE) Study Investigators. Effect of ramipril on mortality and morbidity of survivors of acute myocardial infarction with clinical evidence of heart failure. Lancet 1993;342(8875):821-8. 
153. The SOLVD Investigators. Effect of enalapril on mortality and the development of heart failure in asymptomatic patients with reduced left ventricular ejection fractions. $\mathrm{N}$ Engl J Med 1992;327(10):685-91.

154. The SOLVD Investigators. Effect of enalapril on survival in patients with reduced left ventricular ejection fractions and congestive heart failure. N Engl J Med 1991;325(5):293-302.

155. Cohn JN, Johnson G, Ziesche S, Cobb F, Francis G, Tristani F, et al. A comparison of enalapril with hydralazine-isosorbide dinitrate in the treatment of chronic congestive heart failure. N Engl J Med 1991;325(5):303-10.

156. Group TCTS. Effects of enalapril on mortality in severe congestive heart failure. Results of the Cooperative North Scandinavian Enalapril Survival Study (CONSENSUS). N Engl J Med 1987;316(23):1429-35.

157. Liu YH, Yang XP, Shatov VG, Nass O, Sabbah HN, Peterson E, et al. Effects of angiotensinconverting enzyme inhibitors and angiotensin II type 1 receptor antagonists in rats with heart failure. Role of kinins and angiotensin II type 2 receptors. J Clin Invest 1997;99(8):1926-35.

158. Dickstein K, Gottlieb S, Fleck E, Kostis J, Levine B, DeKock M, et al. Hemodynamic and neurohumoral effects of the angiotensin II antagonist losartan in patients with heart failure. J Hypertens Suppl 1994;12(2):S31-5.

159. Abassi ZA, Kelly G, Golomb E, Klein H, Keiser HR. Losartan improves the natriuretic response to $A N F$ in rats with high- output heart failure. J Pharmacol Exp Ther 1994;268(1):224-30.

160. Gottlieb SS, Dickstein K, Fleck E, Kostis J, Levine TB, LeJemtel T, et al. Hemodynamic and neurohormonal effects of the angiotensin II antagonist losartan in patients with congestive heart failure. Circulation 1993;88(4 Pt 1):1602-9.

161. Tsutsumi $Y$, Matsubara $H$, Masaki $H$, Kurihara $H$, Murasawa S, Takai S, et al. Angiotensin II type 2 receptor overexpression activates the vascular kinin system and causes vasodilation. J Clin Invest 1999;104(7):925-35.

162. Hornig B, Kohler C, Drexler H. Role of bradykinin in mediating vascular effects of angiotensin- converting enzyme inhibitors in humans. Circulation 1997;95(5):1115-8.

163. Gainer JV, Morrow JD, Loveland A, King DJ, Brown NJ. Effect of bradykinin-receptor blockade on the response to angiotensin- converting-enzyme inhibitor in normotensive and hypertensive subjects. N Engl J Med 1998;339(18):1285-92.

164. Gohlke P, Pees $\mathrm{C}$, Unger T. $\mathrm{AT}_{2}$ receptor stimulation increases aortic cyclic GMP in SHRSP by a kinin-dependent mechanism. Hypertension 1998;31(1 Pt 2):349-55.

165. Siragy HM, Carey RM. Protective role of the angiotensin $A T_{2}$ receptor in a renal wrap hypertension model. Hypertension 1999;33(5):1237-42.

166. Campbell DJ, Kladis A, Valentijn AJ. Effects of losartan on angiotensin and bradykinin peptides and angiotensin-converting enzyme. J Cardiovasc Pharmacol 1995;26(2):233-40.

167. Kim S, Iwao H. Molecular and cellular mechanisms of angiotensin II-mediated cardiovascular and renal diseases. Pharmacol Rev 2000;52(1):11-34.

168. Horiuchi M, Akishita $M$, Dzau VJ. Recent progress in angiotensin II type 2 receptor research in the cardiovascular system. Hypertension 1999;33(2):613-21.

169. Barber MN, Sampey DB, Widdop RE. AT(2) receptor stimulation enhances antihypertensive effect of AT(1) receptor antagonist in hypertensive rats. Hypertension 1999;34(5):1112-6.

170. Gigante B, Piras O, De Paolis P, Porcellini A, Natale A, Volpe M. Role of the angiotensin II $\mathrm{AT}_{2}$-subtype receptors in the blood pressure- lowering effect of losartan in salt-restricted rats. J Hypertens 1998;16(12 Pt 2):2039-43.

171. Goto M, Mukoyama M, Suga S, Matsumoto T, Nakagawa M, Ishibashi R, et al. Growthdependent induction of angiotensin II type 2 receptor in rat mesangial cells. Hypertension 1997;30(3 Pt 1):358-62.

172. Munzenmaier DH, Greene AS. Opposing actions of angiotensin II on microvascular growth and arterial blood pressure. Hypertension 1996;27(3 Pt 2):760-5.

173. Stoll M, Steckelings UM, Paul M, Bottari SP, Metzger R, Unger T. The angiotensin $A T_{2-}$ receptor mediates inhibition of cell proliferation in coronary endothelial cells. J Clin Invest 1995;95(2):651-7.

174. Hein L, Barsh GS, Pratt RE, Dzau VJ, Kobilka BK. Behavioural and cardiovascular effects of disrupting the angiotensin II type-2 receptor in mice. Nature 1995;377(6551):744-7. 
175. Schuijt MP, de Vries R, Saxena PR, Danser AH. No vasoactive role of the angiotensin II type 2 receptor in normotensive Wistar rats. J Hypertens 1999;17(12 Pt 2):1879-84.

176. McEwan PE, Gray GA, Sherry L, Webb DJ, Kenyon CJ. Differential effects of angiotensin II on cardiac cell proliferation and intramyocardial perivascular fibrosis in wivo. Circulation 1998;98(24):2765-73.

177. Levy BI, Benessiano J, Henrion D, Caputo L, Heymes C, Duriez M, et al. Chronic blockade of $A T_{2}$-subtype receptors prevents the effect of angiotensin II on the rat vascular structure. J Clin Invest 1996;98(2):418-25.

178. Azizi M, Guyene TT, Chatellier G, Wargon M, Menard J. Additive effects of losartan and enalapril on blood pressure and plasma active renin. Hypertension 1997;29(2):634-40.

179. Menard J, Campbell DJ, Azizi M, Gonzales MF. Synergistic effects of ACE inhibition and Ang II antagonism on blood pressure, cardiac weight, and renin in spontaneously hypertensive rats. Circulation 1997;96(9):3072-8. 


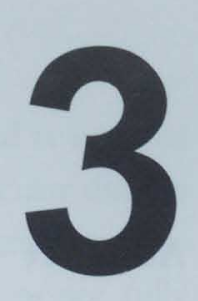

\section{Angiotensin II release from adipose}

tissue and the forearm in lean and

obese subjects in vivo: effect of

$\beta$-adrenergic stimulation

Gijs H. Goossens ${ }^{1}$, Johan W.E. Jocken ${ }^{1}$, Ellen E. Blaak', Paul M. Schiffers ${ }^{2}$, Wim H.M. Saris ${ }^{1}$ and Marleen A. van Baak $^{1}$

${ }^{1}$ Department of Human Biology, Nutrition and Toxicology Research Institute Maastricht (NUTRIM), Maastricht University, Maastricht, The Netherlands

${ }^{2}$ Department of Pharmacology and Toxicology, Cardiovascular Research Institute Maastricht (CARIM), Maastricht University, Maastricht, The Netherlands

In preparation 


\section{Abstract}

The renin-angiotensin system has been implicated in obesity-related disorders, such as hypertension and insulin resistance. We examined whether locally produced angiotensin II (Ang II) in adipose tissue and skeletal muscle plays an endocrine role in lean and obese subjects. Furthermore, the effects of $\beta$-adrenergic stimulation on plasma Ang II concentrations and Ang II fluxes across abdominal subcutaneous adipose tissue and the forearm were investigated in vivo.

Systemic Ang II concentrations and arterio-venous differences of Ang II across both tissues were assessed in combination with measurements of adipose tissue and forearm blood flow before and during systemic $\beta$-adrenergic stimulation in 13 lean and 10 obese subjects.

Basal plasma Ang II concentrations were not significantly different between lean and obese subjects $(8.2 \pm 1.3$ vs. $9.9 \pm 0.9 \mathrm{pmol} / 1, P=0.30$, respectively). $\beta$-Adrenergic stimulation using isoprenaline (ISO) increased Ang II concentrations in obese (baseline: $10.2 \pm 0.9$ vs. ISO: $12.6 \pm 1.5 \mathrm{pmol} / 1, P=0.06$ ), but not in lean subjects (baseline: $7.4 \pm 1.4$ vs. ISO: $8.1 \pm 1.0 \mathrm{pmol} / \mathrm{l}, P=0.38$ ). No significant net Ang II release across adipose tissue and the forearm could be detected in lean $(1.18 \pm 0.84$ fmol $100 \mathrm{~g}$ tissue ${ }^{-1} \cdot \mathrm{min}^{-1}, P=0.20$, and $0.53 \pm 0.57 \mathrm{fmol} \cdot 100 \mathrm{~g}$ tissue ${ }^{-1} \cdot \mathrm{min}^{-1}, P=0.37$, respectively) and obese subjects $\left(0.83 \pm 0.41 \mathrm{fmol} \cdot 100 \mathrm{~g}\right.$ tissue ${ }^{-1} \cdot \mathrm{min}^{-1}, P=0.09$, and $-0.78 \pm 0.44 \mathrm{fmol} \cdot 100 \mathrm{~g}$ tissue ${ }^{-1} \cdot \mathrm{min}^{-1}, P=0.11$, respectively). $\beta$-Adrenergic stimulation had no significant effects on Ang II fluxes across both tissues.

The present data suggest that locally produced Ang II in adipose tissue and the forearm exerts no endocrine tole in normotensive lean and obese subjects. The increased plasma Ang II concentration during $\beta$-adrenergic stimulation in obese subjects cannot be explained by Ang II release from these tissues. 


\section{Introduction}

Abdominal obesity plays a central role in the metabolic syndrome and is a major risk factor for chronic diseases, such as type 2 diabetes and cardiovascular disease (1). Although abdominal obesity is frequently accompanied by hypertension, the mechanisms by which an excess fat mass may lead to hypertension are not fully understood. The renin-angiotensin system (RAS) has been established as a major determinant of blood pressure and cardiovascular disease (2-4). Furthermore, recent clinical trials suggest that blockade of the RAS may reduce the incidence of type 2 diabetes (5). Angiotensin II (Ang II), the main component of the RAS, is produced in the circulation from angiotensinogen (AGT) due to the action of the enzymes renin and angiotensin-converting enzyme (ACE). In addition, it has become evident that several components of the RAS are present in a variety of tissues (6-13), including adipose tissue (14-19) and skeletal muscle (20), implying that these tissues have the ability to produce Ang II.

There is substantial evidence that circulating RAS components are increased in obesity (21-27), and weight loss reduced systemic RAS activity (21). These findings indicate that obesity is responsible for increased systemic RAS activity, and suggest that RAS components that are expressed in adipose tissue may also be secreted into the circulation and exert endocrine effects. This idea is supported by a study in wild-type (WT) mice, AGT knock-out (AGT/-) mice, and mice specifically expressing AGT in adipose tissue, showing that adipocytes are a considerable source of plasma AGT (28). Until now, only one study examined secretion of Ang II from adipose tissue in wivo, and concluded that Ang II concentrations were increased in venous blood draining adipose tissue compared with arterial blood in overweight/obese subjects (29). However, in this study supraphysiological Ang II concentrations were reported, suggesting that the strict methodological procedures to be followed when performing Ang II measurements $(30,31)$ were not taken into account. This raises some doubt on the validity of the findings in this study (29). So far, little information is available on the regulation of the RAS. There is evidence that RAS activity is under control of the sympathetic nervous system. Several studies indicate that $\beta$-adrenergic stimulation increases plasma renin activity (32-36), Ang II release from isolated rat mesenteric arteries (37), and the stimulatory potential of Ang II on aldosterone release (38). Furthermore, it has been shown that local $\beta$-adrenergic stimulation evokes release of renin and angiotensin II from forearm vessels in essential hypertensive subjects $(39,40)$. 
Also, it has been reported that $\beta$-adrenergic stimulation downregulates AGT mRNA expression in 3T3-L1 adipocytes (16) and upregulates AGT mRNA expression in other tissues $(41,42)$. Until now, the effect of $\beta$-adrenergic stimulation on the local RAS in adipose tissue has never been investigated in vivo in humans.

The objective of the present study was to investigate whether abdominal subcutaneous adipose tissue and the forearm release Ang II into the circulation in vivo in lean and obese subjects. Secondly, the effects of $\beta$-adrenergic stimulation on plasma Ang II concentrations and Ang II fluxes across adipose tissue and the forearm were examined in vivo in both groups of subjects.

\section{Methods}

\section{Subjects}

Thirteen lean $\left(B M I<25 \mathrm{~kg} / \mathrm{m}^{2}\right)$ and ten obese $\left(B M I>30 \mathrm{~kg} / \mathrm{m}^{2}\right)$ non-smoking normotensive male subjects participated in this study. Physical characteristics of the subjects are summarized in table 3.1. Body density was determined by hydrostatic weighing after an overnight fast. Lung volume was measured simultaneously with the helium dilution technique using a spirometer (Volugraph 2000, Mijnhardt, Bunnik, The Netherlands). Body weight was measured with a digital balance, accurate to $0.001 \mathrm{~kg}$ (type E1200, August Sauter GmbH, Albstadt, Germany). Body fat percentage was calculated using the equation of Siri (43).

Table 3.1 Subjects' characteristics

\begin{tabular}{lll}
\hline & Lean $(n=13)$ & Obese $(n=10)$ \\
\hline Age (yr) & $49 \pm 3$ & $54 \pm 3$ \\
Weight $(\mathrm{kg})$ & $75.2 \pm 1.5$ & $101.9 \pm 3.2^{\#}$ \\
BMI $\left(\mathrm{kg} / \mathrm{m}^{2}\right)$ & $23.0 \pm 0.5$ & $31.9 \pm 0.6^{\#}$ \\
Body fat $(\%)$ & $20.2 \pm 1.0$ & $31.7 \pm 0.5^{\#}$ \\
Waist circumference (cm) & $87.0 \pm 1.4$ & $111.5 \pm 2.3^{\#}$ \\
SBP (mmHg) & $126.1 \pm 3.4$ & $136.6 \pm 4.3$ \\
DBP (mmHg) & $77.3 \pm 2.4$ & $85.0 \pm 2.7^{*}$ \\
Fasting glucose (mmol/l) & $5.3 \pm 0.1$ & $5.5 \pm 0.2$ \\
Fasting insulin (mU/l) & $7.2 \pm 0.6$ & $13.9 \pm 1.2^{\#}$ \\
Lipid fraction adipose tissue & $0.57 \pm 0.02$ & $0.72 \pm 0.01^{\#}$ \\
Partition coefficient for ${ }^{13.3 X e ~(m l / g) ~}$ & $6.5 \pm 0.2$ & $7.9 \pm 0.1^{\#}$ \\
\hline
\end{tabular}

BMI, body mass index $\left(\mathrm{kg} / \mathrm{m}^{2}\right)$; SBP, systolic blood pressure ( $\mathrm{mmHg}$ ); DBP, diastolic blood pressure (mmHg); ${ }^{13} \mathrm{Xe},{ }^{13} \mathrm{x}$ enon. ${ }^{*} P<0.05$ and $* P<0.001 \mathrm{v}$, lean. Values are means $\pm \mathrm{SEM}$. 
All subjects were in good health as assessed by medical history, free of any medication and spent no more than three hours a week in organized sports activities. The Medical-Ethical Committee of Maastricht University approved the study protocol, and all subjects gave their written informed consent before participating in the study.

\section{Protocol}

All subjects were asked to refrain from drinking alcohol and to perform no strenuous exercise for a period of $24 \mathrm{~h}$ before the study. Subjects came to the laboratory by car or bus in the morning after an overnight fast. Four cannulas were inserted before the start of the experiment. Arterialized venous blood was obtained through a 20-gauge cannula inserted retrogradely into a superficial dorsal hand vein. The hand was warmed in a hot box, which was maintained at $60^{\circ} \mathrm{C}$ to achieve adequate arterialization (44). In the same arm, a second cannula was inserted in a forearm antecubital vein for the infusion of the non-selective $\beta$-adrenergic agonist isoprenaline (ISO). In the contralateral arm, a third catheter was introduced retrogradely in an antecubital vein of the forearm for sampling of deep venous blood, draining skeletal muscle. Finally, after identification of the veins with a fibre-optic light source, a 10-cm 22-gauge catheter (Central venous catheter kit Seldinger technique, Becton Dickinson BV, Alphen aan den Rijn, The Netherlands) was anterogradely introduced over a guide wire into one of the superficial veins on the anterior abdominal wall and threaded towards the groin, so that its tip lay just superior to the inguinal ligament, to obtain adipose tissue venous blood (45). This provides the drainage from the adipose tissue of the abdomen, uncontaminated by muscle drainage and with only a minor contribution from skin (45-47). The adipose vein was kept patent by continuous saline $(9 \mathrm{~g} / \mathrm{l}$ $\mathrm{NaCl}$ ) infusion at a rate of $80 \mathrm{ml} / \mathrm{h}$. The subjects rested in a supine position for the duration of the study.

\section{Ang II release into the circulation}

Circulating Ang II concentrations and net Ang II release from abdominal subcutaneous adipose tissue and the forearm into the circulation were investigated in wivo under baseline conditions and during intravenous infusion of ISO. Following a $120 \mathrm{~min}$ baseline period, ISO was intravenously infused at a rate of $20 \mathrm{ng} \cdot \mathrm{kgFFM}^{-1} \cdot \mathrm{min}^{-1}$ for 60 minutes (48). During the experiment, heart rate was recorded continuously by means of a three-lead ECG. When heart rate increased 
more than 40 beats/min or in case of ECG irregularities, ISO infusion was discontinued $(n=2)$.

Blood samples were taken simultaneously from the arterialized vein, the adipose vein and the deep forearm vein, while the hand circulation was occluded, at three baseline time points $(\mathrm{t} 90, \mathrm{t} 105$ and $\mathrm{t} 120)$ and three time points during the last 30 min of ISO infusion ( $t 160, t 175$ and $t 190$ ). Adipose tissue blood flow (ATBF) was monitored continuously and forearm blood flow (FBF) was measured before each blood sample. Plasma flow was calculated as tissue blood flow $\times(1$-hematocrit), with hematocrit expressed as a fraction. Ang II fluxes across adipose tissue and the forearm were calculated from the arterio-venous concentration differences multiplied by tissue plasma flow. Positive fluxes indicate net uptake from plasma, whereas negative fluxes indicate net tissue release.

\section{Adipose tissue blood flow}

ATBF was measured using the xenon (133Xe) wash-out technique (49). Briefly, ${ }^{133} \mathrm{Xe}(\sim 8 \mathrm{MBq})$ was injected para-umbilically into the adipose tissue, approximately $10 \mathrm{~mm}$ deep, using an insulin-injection syringe with a fine needle (0.36 mm external diameter). A CsI crystal detector (Oakfield Instruments, Eynsham, UK) was placed over the exact site of injection and taped firmly in place to monitor the mono-exponential decay of radioactivity in the adipose tissue. This $\gamma$-counter probe collected continuous 20 s readings (50). ATBF was calculated from the semilog plot of disappearance of counts versus time in 20 s intervals. For the calculation of quantitative values of ATBF (per $100 \mathrm{~g}$ tissue), the relative solubility of xenon between tissue and blood, i.e. the partition coefficient, and the lipid fraction of adipose tissue (V) must be known, as has been described previously (51). Briefly,

Lipid fraction (V):

$\mathrm{V}=0.327+(0.0124 \times \%$ adiposity $)(r=0.95, P<0.005)(52)$

Tissue-blood partition coefficient of ${ }^{133} \mathrm{Xe}$ for adipose tissue $(\lambda)$ :

$\lambda=\left[\mathrm{V}\left(\mathrm{S}_{\mathrm{I}} / \mathrm{S}_{\mathrm{P}}-1\right)+1\right] /\left[\mathrm{Ht}\left(\mathrm{S}_{\mathrm{C}} / \mathrm{S}_{\mathrm{P}}-1\right)+1\right]$

whereby $H t$ is the hematocrit (expressed as a fraction), $S_{p}$ (solubility in plasma) is $0.0939 \mathrm{ml} / \mathrm{ml}, \mathrm{S}_{\mathrm{L}}$ (solubility in lipid) is $1.8276 \mathrm{ml} / \mathrm{g}$, and $\mathrm{S}_{\mathrm{C}}$ (solubility in red blood cells) is $0.2710 \mathrm{ml} / \mathrm{ml}$. On the basis of this equation, the tissue-blood pattition coefficient was calculated for each individual. 
Adipose tissue blood flow:

ATBF $\left(\mathrm{ml} \cdot 100 \mathrm{~g}\right.$ tissue $\left.{ }^{-1} \cdot \mathrm{min}^{-1}\right)=$ slope of semilog plot $\times \lambda \times 100$ (49)

\section{Forearm blood flow}

FBF was measured by venous occlusion plethysmography (EC5R plethysmograph, Hokanson, Bellevue, USA) using mercury-in-silastic strain gauges applied to the widest part of the forearm (53). During measurement periods, the hand circulation was occluded by rapid inflation of a sphygmomanometer cuff (E20 rapid cuff inflator, Hokanson, Bellevue, USA) placed around the wrist to a pressure of 200 $\mathrm{mmHg}$. In this way, FBF can be assessed without interference of the hand circulation. A cuff placed around the upper arm was inflated (and deflated) to 45 $\mathrm{mmHg}$ to achieve venous occlusion and obtain plethysmographic recordings. During venous occlusion, the plethysmographic recordings reflect the rate of arterial inflow indicating FBF.

\section{Analyses}

Blood samples were collected into syringes containing either EDTA or Ang II buffer (54), and immediately transferred into ice-chilled polypropylene tubes. Blood samples were then centrifuged $\left(3000 \mathrm{rpm}, 4^{\circ} \mathrm{C}, 10\right.$ minutes) and plasma was immediately frozen in liquid nitrogen and stored at $-80^{\circ} \mathrm{C}$ until analysis. A small proportion of blood was used for measurement of oxygen saturation $\left(\% \mathrm{HbO}_{2}\right)$ to ensure adequate arterialization (ABL 510, Radiometer, Copenhagen, Denmark).

Ang II was measured by a standard radioimmunoassay (Peninsula Laboratories Europe, St. Helens, UK) following C-18 Sep-Pak (Waters-Millipore) extraction of the peptide. Intra- and interassay coefficients of variation were $4.6 \%$ and $7.7 \%$, respectively. Plasma glucose concentration was measured using a standard enzymatic method (ABX Pentra Glucose HK CP, Radiometer, Copenhagen, Denmark). Plasma insulin concentration was measured by a specific double antibody radioimmunoassay for human insulin (Linco Research Inc., St. Charles, Missouri, USA).

\section{Statistical analysis}

Data are presented as mean \pm standard error of the mean (SEM). Differences between lean and obese subjects were compared using Student's unpaired t-test. The effects of $\beta$-adrenergic stimulation within groups were tested using Student's 
paired $t$-test. Calculations were done using SPSS 10.1 for Windows (Chicago, IL, USA). $P<0.05$ was considered to be statistically significant.

\section{Results}

By definition, obese men had a significantly higher body weight, body mass index, and body fat percentage compared with lean men, as summarized in table 3.1 .

\section{Adipose tissue and forearm blood flow}

Basal ATBF was significantly higher in lean compared with obese subjects $(2.2 \pm 0.2$ vs. $1.4 \pm 0.2 \mathrm{ml} \cdot 100 \mathrm{~g}$ tissue ${ }^{-1} \cdot \mathrm{min}^{-1}, P<0.05$, respectively), whereas basal FBF was comparable between lean and obese subjects $(2.9 \pm 0.2 v \mathrm{~s} .2 .4 \pm 0.3 \mathrm{ml} \cdot 100 \mathrm{ml}$ forearm tissue ${ }^{-1} \cdot \mathrm{min}^{-1}, P=0.15$, respectively) (figure 3.1 ).

$\beta$-Adrenergic stimulation induced a significant increase in tissue blood flows. ATBF significantly increased during $\beta$-adrenergic stimulation compared with baseline in both lean $\left(6.3 \pm 1.2\right.$ vs. $2.2 \pm 0.2 \mathrm{ml} \cdot 100 \mathrm{~g}$ tissue $\mathrm{e}^{-1} \cdot \mathrm{min}^{-1}, P=0.005$, respectively) and obese subjects $\left(3.6 \pm 0.6 v\right.$ s. $1.6 \pm 0.2 \mathrm{ml} \cdot 100 \mathrm{~g}$ tissue $^{-1} \cdot \mathrm{min}^{-1}, P=0.02$, respectively). Furthermore, $\mathrm{FBF}$ was significantly elevated during $\beta$-adrenergic stimulation in both lean $\left(4.6 \pm 0.4\right.$ vs. $2.9 \pm 0.2 \mathrm{ml} \cdot 100 \mathrm{ml}$ forearm tissue ${ }^{-1} \cdot \mathrm{min}^{-1}$, $P=0.001)$ and obese subjects $\left(3.5 \pm 0.3\right.$ vs. $2.5 \pm 0.3 \mathrm{ml} \cdot 100 \mathrm{ml}$ forearm tissue ${ }^{-1} \cdot \mathrm{min}^{-1}$, $P=0.001$ ) (figure 3.1). The increase in $A T B F$ and FBF during $\beta$-adrenergic stimulation was not significantly different between groups $(P=0.16$ and $P=0.24$, respectively).

\section{Plasma Ang II concentrations}

Basal plasma Ang II concentrations were not significantly different between lean $(n=13)$ and obese $(n=10)$ subjects $(8.2 \pm 1.3$ vs. $9.9 \pm 0.9 \mathrm{pmol} / 1, P=0.30$, respectively) (figure 3.2). $\beta$-Adrenergic stimulation had no significant effect on circulating Ang II concentrations in lean $(n=12)$ subjects (baseline: $7.4 \pm 1.4 v$ s. ISO: $8.1 \pm 1.0 \mathrm{pmol} / \mathrm{l}$, $P=0.38)$. However, Ang II concentrations increased during ISO infusion in obese $(n=9)$ subjects (baseline: $10.2 \pm 0.9$ vs. ISO: $12.6 \pm 1.5 \mathrm{pmol} / \mathrm{l}, P=0.06$ ), and resulred in significantly higher Ang II concentrations during $\beta$-adrenergic stimulation in obese compared with lean subjects $(P=0.02)$ (figure 3.2 ). 


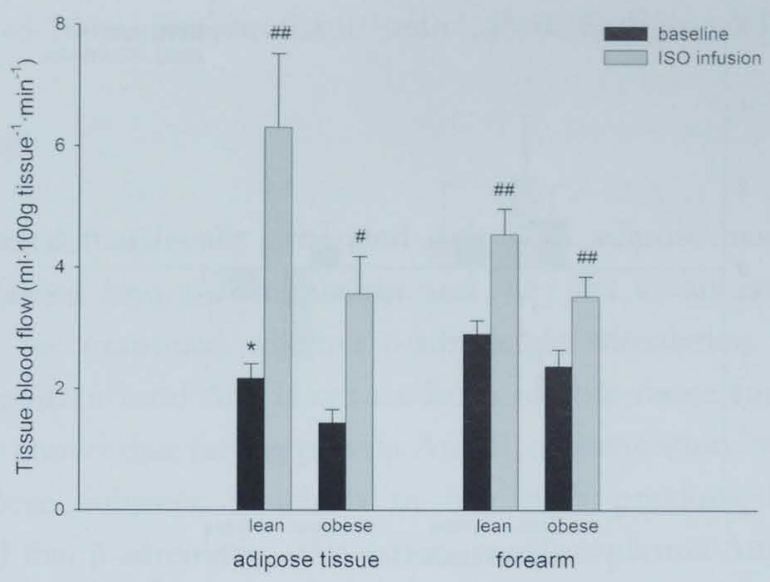

Figure 3.1 Adipose tissue and forearm blood flow in lean and obese subjects under baseline conditions and during $\beta$-adrenergic stimulation with ISO. Student's unpaired $t$-test, ${ }^{*} P<0.05 v$ s. obese; Student's paired $t$-test, ${ }^{\#} P<0.05 v$ s. baseline, ${ }^{\#} P<0.01 v$ s. baseline. Values are means \pm SEM.

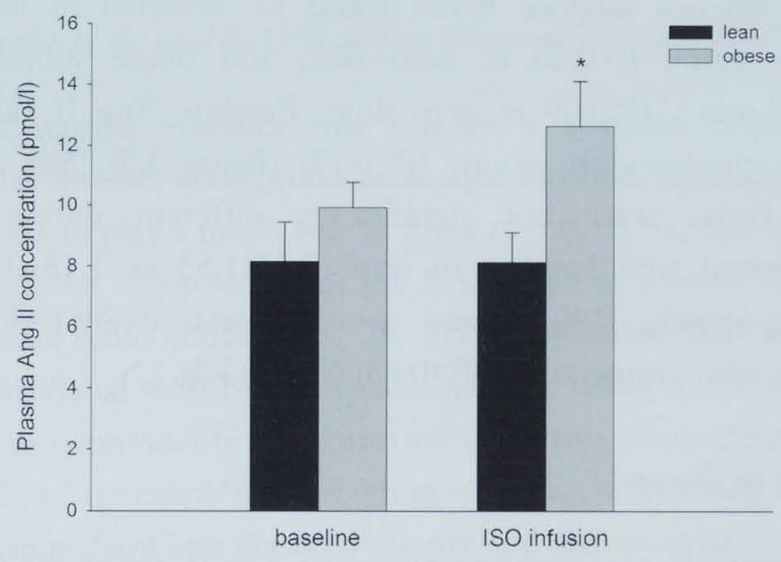

Figure 3.2 Plasma Ang II concentrations in lean and obese subjects under baseline conditions and during $\beta$-adrenergic stimulation with ISO. Student's unpaired $t$-test, $* P<0.05$ vs. lean. Values are means \pm SEM. 


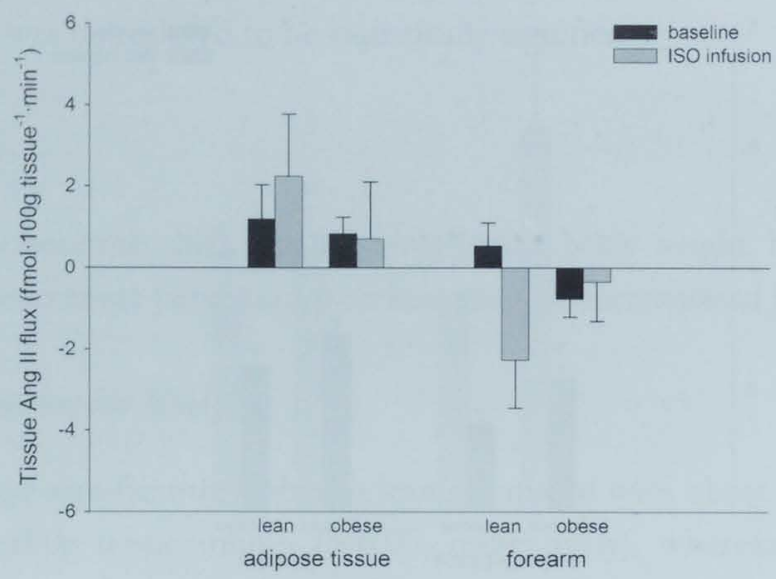

Figure 3.3 Ang II fluxes actoss abdominal subcutaneous adipose tissue and the forearm in lean and obese subjects under baseline conditions and during $\beta$-adrenergic stimulation (ISO infusion). Positive fluxes indicate net uptake from plasma, whereas negative fluxes indicate net tissue release. Values are means \pm SEM.

\section{Ang II fluxes across abdominal subcutaneous adipose tissue}

Under baseline conditions, no significant net uptake or release of Ang II across abdominal subcutaneous adipose tissue could be detected in lean $(1.18 \pm 0.84$ fmol $\cdot 100 \mathrm{~g}$ tissue ${ }^{-1} \cdot \mathrm{min}^{-1}, P=0.20$ vs. zero flux $)$ and obese subjects $(0.83 \pm 0.41$ fmol $\cdot 100 \mathrm{~g}$ tissue $^{-1} \cdot \mathrm{min}^{-1}, P=0.09$ vs. zero flux). Baseline Ang II fluxes were not significantly different between groups ( $P=0.73$ ) (figure 3.3). Net Ang II fluxes across adipose tissue were not significantly different during $\beta$-adrenergic stimulation compared with baseline in lean $(2.24 \pm 1.53$ vs. $1.18 \pm 0.84 \mathrm{fmol} \cdot 100 \mathrm{~g}$ tissue $^{-1} \cdot \mathrm{min}^{-1}$, respectively, $\left.P=0.62\right)$ and obese subjects $(0.70 \pm 1.41$ vs. $0.99 \pm 0.44$ fmol $100 \mathrm{~g}$ tissue ${ }^{-1} \cdot \mathrm{min}^{-1}$, respectively, $P=0.83$ ) (figure 3.3 ).

\section{Ang II fluxes across the forearm}

There was no detectable net uptake or release of Ang II across the forearm under baseline conditions in lean $\left(0.53 \pm 0.57 \mathrm{fmol} \cdot 100 \mathrm{~g}\right.$ tissue $^{-1} \cdot \mathrm{min}^{-1}, P=0.37 \mathrm{vs}$. zero flux $)$ and obese subjects $\left(-0.78 \pm 0.44 \mathrm{fmol} \cdot 100 \mathrm{~g}\right.$ tissue ${ }^{-1} \cdot \mathrm{min}^{-1}, P=0.11$ vs. zero flux $)$. Baseline Ang II fluxes were not significantly different between groups $(P=0.10)$ (figure 3.3). $\beta$-Adrenergic stimulation had no significant effect on net Ang II fluxes across the forearm in lean (baseline, $-0.02 \pm 0.48$ vs. ISO, $-2.28 \pm 1.17 \mathrm{fmol} \cdot 100 \mathrm{ml}$ 
forearm tissue $e^{-1} \mathrm{~min}^{-1}, P=0.18$ ) and obese subjects (baseline, $-0.75 \pm 0.49$ vs. ISO, $-0.36 \pm 0.96 \mathrm{fmol} \cdot 100 \mathrm{ml}$ forearm tissue ${ }^{-1} \cdot \mathrm{min}^{-1}, P=0.78$ ) (figure 3.3 ).

\section{Discussion}

We hypothesized that locally generated Ang II in adipose tissue and/or skeletal muscle is released into the circulation and may act as an endocrine hormone. Furthermore, we examined whether $\beta$-adrenergic stimulation increases systemic RAS activity and/or local Ang II release from adipose tissue and the forearm. The present study shows that fasting plasma Ang II concentrations were comparable in lean and obese subjects, which is in line with previous findings (21). We demonstrated that $\beta$-adrenergic stimulation increases plasma Ang II concentrations in obese, but not in lean subjects. Determination of Ang II fluxes across abdominal subcutaneous adipose tissue and the forearm under baseline conditions and during $\beta$-adrenergic stimulation revealed that there was no significant net uptake or release of Ang II across abdominal subcutaneous adipose tissue and the forearm in lean and obese subjects under both conditions. Thus, the increased plasma Ang II concentrations observed in obese subjects during $\beta$-adrenergic stimulation cannot be explained by Ang II release from abdominal subcutaneous adipose tissue and the forearm.

\section{Endocrine function of the local $R A S$ in adipose tissue and skeletal muscle?}

There is substantial evidence that obesity is a prime cause of hypertension, cardiovascular disease, and insulin resistance in obese individuals $(1,55,56)$, and the RAS seems to play a major role in these events $(2,57,58)$. Human studies have demonstrated that components of the RAS, such as plasma AGT concentrations (21-25), plasma renin activity $(21,26,27)$ and plasma ACE activity (21, 23), are positively correlated with BMI. Because adipose tissue exerts endocrine functions (59), and RAS components are expressed in human adipose tissue $(14,15,17,21)$, it is tempting to speculate that secretion of RAS components from adipose tissue could be an important link between obesity and obesity-related complications, such as insulin resistance and hypertension. A recent report demonstrated that 5\% weight loss was accompanied by decreased systemic RAS activity (21), which further suggests that obesity is responsible for increased systemic RAS activity. The concept that RAS components that are expressed in adipose tissue may exert endocrine effects is supported by a study where WT mice were compared with AGT $\%$ mice, and with transgenic mice specifically expressing AGT in adipose 
tissue either on the AGT $\%$ background or on the WT background. It was shown that adipocytes are a considerable source of plasma AGT, which may explain the observed elevated blood pressure in the transgenic animals (28).

Until now, only one recent study assessed Ang II secretion from adipose tissue in vivo, and concluded that Ang II concentrations were increased in venous blood draining abdominal subcutaneous adipose tissue compared with arterial blood (29). However, when measuring Ang II it is crucial to use Ang II buffer to eliminate breakdown as well as further production of Ang II during processing of the samples $(30,31,54)$. This buffer was not used in the study by Harte and colleagues (29), which may explain the reported supraphysiological Ang II concentrations. In the present study, we used Ang II buffer and measured Ang II using a radioimmunoassay with intra-assay coefficients of variation $<5 \%$. We could not demonstrate net uptake or release of Ang II across abdominal subcutaneous adipose tissue and the forearm in lean and obese subjects under baseline conditions. Our forearm data are in line with previous findings demonstrating that Ang II is not released from the forearm under baseline conditions in hypertensive patients (40). However, we cannot exclude the possibility that there is net release of other RAS components, such as AGT and renin, from these tissues, which may subsequently be converted into Ang II in the circulation. In other words, although we have demonstrated that there is no net release of Ang II from abdominal subcutaneous adipose tissue and the forearm, further research is necessary to establish whether other components of the RAS are secreted from these tissues and exert an endocrine function. Furthermore, it is possible that there are regional differences in Ang II secretion from adipose tissue. As has been shown for other adipokines, AGT mRNA expression has been demonstrated to be elevated in visceral compared with subcutaneous adipose tissue $(60,61)$, which suggests that RAS activity may be elevated in the visceral fat depot compared with abdominal subcutaneous adipose tissue.

\section{$\beta$-adrenergic stimulation and $\mathrm{R} A S$ activity}

The present results show for the first time that systemic $\beta$-adrenergic stimulation increases plasma Ang II concentrations in obese individuals, but has no significant effect on circulating Ang II concentrations in lean subjects. It has previously been demonstrated in humans that the $\beta$-adrenergic system at least acutely stimulates renin production at different steps of its biosynthesis or secretion $(33,34)$. In addition, in vitro findings in isolated rat mesenteric arteries indicate that locally generated Ang II may be released by $\beta_{2}$-adrenergic activation (37). The increased 
plasma Ang II concentrations in obese subjects during ISO infusion suggests that the stimulatory effect of $\beta$-adrenergic activation on RAS activity is more pronounced in obese compared with lean subjects. This effect could be mediated in part by the hyperinsulinemia that occurred in obese subjects during $\beta$-adrenergic stimulation. This in turn may increase AGT protein expression in adipose tissue (62) and the release of this peptide from adipose tissue into the circulation, where it can be converted into Ang II. Alternatively, the fact that systemic RAS activity is already increased in obese compared with lean subjects under baseline conditions (21) may underlie this observation. Subsequent $\beta$-adrenergic stimulation may further increase RAS activity, resulting in increased Ang II production as reflected by increased circulating Ang II concentrations in obese subjects.

The present data further show that $\beta$-adrenergic stimulation has no significant effects on net Ang II fluxes across abdominal subcutaneous adipose tissue and the forearm in lean and obese subjects. Local $\beta$-adrenergic stimulation has previously been shown to induce renin and Ang II release from forearm vessels in essential hypertensive subjects $(39,40)$. At first sight, the absence of detectable Ang II release from the forearm in the present study appears to be in contradiction with findings of Taddei and co-workers $(39,40)$, but several explanations may be responsible for this apparent discrepancy. First, the subjects in their studies were hypertensive $(39,40)$ and moderately sodium depleted, a condition associated with increased activation of the RAS (63), while the subjects that participated in the present study were normotensive and maintained their normal dietary sodium intake. Moreover, in one of their studies only subjects with plasma renin activity values above $1 \mathrm{pmol}$ Ang $\mathrm{I} / \mathrm{ml}$ per hour were included (39). Thus, although we have not measured plasma renin activity, it is likely that plasma renin concentrations were lower in the present study. The finding that Ang II release from the forearm was closely correlated with circulating renin concentrations (40) suggests that the tissue RAS in skeletal muscle is at least partly dependent on uptake of renin from the circulation and may explain the present observations. Secondly, local $\beta$-adrenergic stimulation (intrabrachial infusion) (40) may have caused a more pronounced stimulus compared with intravenous infusion of a $\beta$ adrenergic agonist in the present study (48). This is supported by the fact that the increase in FBF during local $\beta$-adrenergic stimulation was more pronounced than the elevation in FBF observed in the present study. Thirdly, it has been shown that the release of renin and Ang II across the forearm during local $\beta$-adrenergic stimulation rapidly declines after 5-10 min (40), indicating that this system might represent a short-term control mechanism. Since in the present study Ang II 
release was assessed during the last $30 \mathrm{~min}$ of a $1 \mathrm{~h}$ ISO infusion, downregulation of local Ang II generation may have occurred, resulting in undetectable Ang II release from the forearm.

Although it has been reported that $\beta$-adrenergic stimulation downregulates AGT mRNA expression in 3T3-L1 adipocytes (16), the effect of $\beta$-adrenergic stimulation on the local RAS in adipose tissue has never been investigated in vivo in humans. Because it is well-established that Ang II is produced by human adipocytes (14, 64), our data suggest that locally produced Ang II in adipose tissue acts as an autocrine and/or paracrine hormone, and does not exert endocrine effects.

\section{Perspectives}

The present findings demonstrate that net Ang II uptake or release across abdominal subcutaneous adipose tissue and the forearm is undetectable under baseline conditions and during $\beta$-adrenergic stimulation. This implies that the observed increase in plasma Ang II concentrations during $\beta$-adrenergic stimulation in obese subjects is explained by other factors than Ang II release from abdominal subcutaneous adipose tissue and/or the forearm. It is intriguing to speculate that increased release of other RAS components, such as AGT and renin, from adipose tissue in obese subjects may contribute to the increased plasma Ang II concentrations in these individuals during $\beta$-adrenergic stimulation. Alternatively, Ang II production in the circulation or local Ang II secretion from other tissues than abdominal subcutaneous adipose tissue and the forearm, such as the kidney and liver, may explain this observation. Further research is necessary to elucidate this.

\section{Acknowledgements}

The authors would like to thank Marie-Thérèse Pakbiers, Anneke van Hees and Paula van der Baan for their excellent practical support.

\section{References}

1. Reaven GM. Banting lecture 1988. Role of insulin resistance in human disease. Diabetes 1988;37(12):1595-607.

2. Unger $\mathrm{T}$. The role of the renin-angiotensin system in the development of cardiovascular disease. Am J Cardiol 2002;89(2A):3A-9A; discussion $10 \mathrm{~A}$.

3. Kim S, Iwao H. Molecular and cellular mechanisms of angiotensin II-mediated cardiovascular and renal discases. Pharmacol Rev 2000;52(1):11-34. 
4. Timmermans PB, Wong PC, Chiu AT, Herblin WF, Benfield P, Carini DJ, et al. Angiotensin II receptors and angiotensin II teccptor antagonists. Pharmacol Rev 1993;45(2):205-51.

5. Jandeleit-Dahm KA, Tikellis C, Reid CM, Johnston CI, Cooper ME. Why blockade of the renin-angiotensin system reduces the incidence of new-onset diabetes. J Hypertens 2005;23(3):463-73.

6. Hollenberg NK, Fisher ND, Price DA. Pathways for angiotensin II generation in intact human tissue: evidence from comparative pharmacological interruption of the renin system. Hypertension 1998;32(3):387-92.

7. Riordan JF. Angiotensin II: biosynthesis, molecular recognition, and signal transduction. Cell Mol Neurobiol 1995;15(6):637-51.

8. Phillips MI, Speakman EA, Kimura B. Levels of angiotensin and molecular biology of the tissue renin angiotensin systems. Regul Pept 1993;43(1-2):1-20.

9. Chai SY, Zhuo J, Mendelsohn FA. Localization of components of the renin-angiotensin system and site of action of inhibitors. Arzneimittelforschung 1993;43(2A):214-21.

10. Dostal DE, Rothblum KN, Chernin MI, Cooper GR, Baker KM. Intracardiac detection of angiotensinogen and renin: a localized renin- angiotensin system in neonatal rat heart. Am J Physiol 1992;263(4 Pt 1):C838-50.

11. Multow PJ. Adrenal renin: regulation and function. Front Neuroendoctinol 1992;13(1):47-60.

12. Drau VJ, Ellison KE, Brody $T$, Ingelfinger J, Pratt RE. A comparative study of the distributions of renin and angiotensinogen messenger ribonucleic acids in rat and mouse tissucs. Endocrinology 1987;120(6):2334-8.

13. Murakami E, Eggena P, Barrett JD, Sambhi MP. Heterogeneity of renin substrate released from hepatocytes and in brain extracts. Life Sci 1984;34(4):385-92.

14. Schling $P$, Mallow $H$, Trindl A, Loffler $G$. Evidence for a local renin angiotensin system in primary cultured human preadipocytes. Int J Obes Relat Metab Disord 1999;23(4):336-41.

15. Karlsson C, Lindell K, Ottosson M, Sjostrom L, Carlsson B, Carlsson LM. Human adipose tissue expresses angiotensinogen and enzymes required for its conversion to angiotensin II. J Clin Endocrinol Mctab 1998;83(11):3925-9.

16. Jones BH, Standridge MK, Taylor JW, Moustaid N. Angiotensinogen gene expression in adipose tissue: analysis of obese models and hormonal and nutritional control. Am J Physiol 1997;273(1 Pt 2):R236-42.

17. Jonsson JR, Game P $\lambda$, Head RJ, Frewin DB. The expression and localisation of the angiotensin-converting enzyme mRNA in human adipose tissue. Blood Press 1994;3(1-2):72-5.

18. Crandall DL, Herzlinger HE, Saunders BD, Zolotor RC, Feliciano L, Cerroni P. Identification and characterization of angiotensin II receptors in rat epididymal adipocyte membranes. Metabolism 1993;42(4):511-5.

19. Cassis $J A$, Saye J, Peach MJ. Location and regulation of rat angiotensinogen messenger RN $\lambda$. Hypertension 1988;11(6 Pt 2):591-6.

20. Jones $A$, Woods DR. Skeletal muscle RAS and exercise performance. Int J Biochem Cell Biol 2003;35(6):855-66.

21. Engeli S, Bohnke J, Gorzelniak K, Janke J, Schling P, Bader M, et al. Weight Loss and the Renin- Angiotensin-Aldosterone System. Hypertension 2005.

22. Cooper R, Forrester T, Ogunbiyi $O$, Muffinda J. Angiotensinogen levels and obesity in four black populations. ICSHIB Investigators. J Hypertens 1998;16(5):571-5.

23. Cooper R, McFarlane-Anderson N, Bennett FI, Wilks R, Puras $A$, Tewksbury D, et al. $A C E$, angiotensinogen and obesity: a potential pathway leading to hypertension. J Hum Hypertens 1997;11(2):107-11.

24. Umemura S, Nyui N, Tamura K, Hibi K, Yamaguchi S, Nakamaru M, et al. Plasma angiotensinogen concentrations in obese patients. Am J Hypertens 1997;10(6):629-33.

25. Blocm LJ, Manatunga AK, Tewksbury DA, Pratt JH. The serum angiotensinogen concentration and variants of the angiotensinogen gene in white and black children. $J$ Clin Invest 1995;95(3):948-53.

26. Licata G, Scaglione R, Ganguzza A, Corrao S, Donatelli M, Parrincllo G, et al. Central obesity and hypertension. Relationship between fasting scrum insulin, plasma renin activity, and diastolic blond pressure in young obese subjects. A $\mathrm{m}$ J Hypertens 1994;7(4 Pt 1):314-20. 
27. Egan BM, Stepniakowski K, Goodfriend TL. Renin and aldosterone are higher and the hyperinsulinemic effect of salt restriction greater in subjects with risk factors clustering. $\mathrm{Am} J$ Hypertens 1994;7(10 Pt 1):886-93.

28. Massiera F, Bloch-Faure M, Ceiler D, Murakami K, Fukamizu A, Gasc JM, et al. Adipose angiotensinogen is involved in adipose tissue growth and blood pressure regulation. Faseb J 2001;15(14):2727-9.

29. Harte A, McTernan P, Chetty R, Coppack S, Katz J, Smith S, et al. Insulin-mediated upregulation of the renin angiotensin system in human subcutaneous adipocytes is reduced by rosiglitazone. Circulation 2005;111(15):1954-61.

30. Schalekamp MA, Derkx FH, van den Meiracker AH. Renin inhibitors, angiotensin converting enzyme inhibitors and angiotensin II receptor antagonists: relationships between blood pressure responses and effects on the renin-angiotensin system. J Hypertens Suppl 1992;10(7):S157-64.

31. Chai W, Danser AH. Is angiotensin II made inside or outside of the cell? Curr Hypertens Rep 2005;7(2):124-7.

32. Zayas VM, Blumenfeld JD, Bading B, McDonald M, James GD, Lin YF, et al. Adrenergic regulation of renin secretion and renal hemodynamics during deliberate hypotension in humans. Am J Physiol 1993;265(5 Pt 2):F686-92.

33. Hsueh WA, Goldstone R, Carlson EJ, Horton R. Evidence that the beta-adrenergic system and prostaglandins stimulate renin release through different mechanisms. J Clin Endocrinol Metab 1985;61(3):399-403.

34. Pettinger WA, Mitchell HC. Renin release, saralasin and the vasodilator-beta-blocker drug interaction in man. N Engl J Med 1975;292(23):1214-7.

35. Ramsay DJ. Beta-adrenergic thirst and its relation to the renin-angiotensin system. Fed Proc 1978;37(13):2689-93.

36. Sinaiko AR. Influence of adrenergic nervous and prostaglandin systems on hydralazineinduced renin release. Life Sci 1983;33(23):2269-75.

37. Nakamaru M, Jackson EK, Inagami $T$. Role of vascular angiotensin II released by betaadrenergic stimulation in rats. J Cardiovasc Pharmacol 1986;8(Suppl 10):S1-5.

38. Pratt JH, McAteer JA. Beta-adrenergic enhancement of angiotensin II-stimulated aldosterone secretion. Life Sci 1989;44(26):2089-95

39. Taddei S, Virdis A, Mattei P, Favilla S, Salvetti A. Angiotensin II and sympathetic activity in sodium-restricted essential hypertension. Hypertension 1995;25(4 Pt 1):595-601.

40. Taddei $\mathrm{S}$, Salvetti A. Vascular tissue renin-angiotensin system in hypertensive humans. J Hypertens Suppl 1992;10(7):S165-72.

41. Dostal DE, Booz GW, Baker KM. Regulacion of angiotensinogen gene expression and protein in neonatal tat cardiac fibroblasts by glucocorticoid and beta-adrenergic stimulation. Basic Res Cardiol 2000;95(6):485-90.

42. Jikihara $\mathrm{H}$, Handwerger $\mathrm{S}$, Poisner AM. Beta-adrenergic regulation of renin expression in differentiated U-937 monocytic cells. Biochem Pharmacol 1997;53(12):1883-8.

43. Siri WE. The gross composition of the body. Adv Biol Med Physiol 1956;4:239-280.

44. Abumrad NN, Rabin D, Diamond MP, Lacy WW. Use of a heated superficial hand vein as an alternative site for the measurement of amino acid concentrations and for the study of glucose and alanine kinetics in man. Metabolism 1981;30(9):936-40.

45. Frayn KN, Coppack SW, Humphreys SM, Whyte PL. Metabolic characteristics of human adipose tissue in vivo. Clin Sci (Colch) 1989;76(5):509-16.

46. Coppack SW, Frayn KN, Humphreys SM, Dhar H, Hockaday TD. Effects of insulin on human adipose tissue metabolism in vivo. Clin Sci (Colch) 1989;77(6):663-70.

47. Coppack SW, Frayn KN, Humphreys SM, Whyte PL, Hockaday TD. Arteriovenous differences across human adipose and forearm tissues after overnight fast. Metabolism 1990;39(4):384-90.

48. Blaak EE, Van Baak MA, Kemerink GJ, Pakbiers MT, Heidendal GA, Saris WH. Betaadrenergic stimulation of energy expenditure and forearm skeletal muscle metabolism in lean and obese men. Am J Physiol 1994;267(2 Pt 1):E306-15.

49. Larsen $\mathrm{OA}$, Lassen $N A$, Quaade F. Blood flow through human adipose tissue determined with radioactive xenon. Acta Physiol Scand 1966;66(3):337-45. 
50. Samra JS, Frayn KN, Giddings J $A$, Clark ML, Macdonald IA. Modification and validation of a commercially available portable detector for measurement of adipose tissue blood flow. Clin Physiol 1995;15(3):241-8.

51. Blaak EE, van Baak MA, Kemerink GJ, Pakbiers MT, Heidendal GA, Saris WH. Betaadrenergic stimulation and abdominal subcutaneous fat blood flow in lean, obese, and reducedobese subjects. Metabolism 1995;44(2):183-7.

52. Martin $A D$, Daniel MZ, Drinkwater DT, Clarys JP. Adipose tissue density, estimated adipose lipid fraction and whole body adiposity in male cadavers. Int ] Obes Relat Metab Disord 1994;18(2):79-83.

53. Webb DJ. The pharmacology of human blood vessels in vivo. J Vasc Res 1995;32(1):2-15.

54. Ferrario CM, Brosnihan KB, Chappell M. Measurements of angiotensin peptides. Hypertension 1995;26(5):843-5.

55. Mikhail N, Golub MS, Tuck ML. Obesity and hypertension. Prog Cardiovasc Dis 1999;42(1):39-58.

56. Wilson PW, D'Agostino RB, Sullivan L, Parise H, Kannel WB. Overveight and obesity as determinants of cardiovascular risk: the Framingham experience. Arch Intern Med 2002;162(16):1867-72.

57. Goossens GH, Blaak EE, van Baak MA. Possible involvement of the adipose tissue reninangiotensin system in the pathophysiology of obesity and obesity-related disorders. Obes Rev $2003 ; 4(1): 43-55$.

58. Strazzullo P, Galletti F. Impact of the renin-angiotensin system on lipid and carbohydrate metabolism. Curr Opin Nephrol Hypertens 2004;13(3):325-32.

59. Kershaw EE, Flier JS. Adipose tissue as an endocrine organ. J Clin Endocrinol Metab 2004;89(6):2548-56.

60. Giacchetti G, Faloia E, Sardu C, Camilloni MA, Mariniello B, Gatti C, et al. Gene expression of angiotensinogen in adipose tissue of obese patients. Int $\mathrm{J}$ Obes Relat Metab Disord 2000;24:S142-3.

61. van Harmelen V, Elizalde M, Ariapart P, Bergstedt-Lindqvist S, Reynisdottir S, Hoffstedt J, et al. The association of human adipose angiotensinogen gene expression with abdominal fat distribution in obesity. Int J Obes Relat Metab Disord 2000;24(6):673-8.

62. Harte $A L$, McTernan PG, McTernan CL, Crocker J, Starcynski J, Barnett $A H$, et al. Insulin increases angiotensinogen expression in human abdominal subcutancous adipocytes. Diabetes Obes Metab 2003;5(6):462-7.

63. Salvetti $A$, Pedrinelli $R$, Magagna $A$, Poli L, Sassano P, Arzilli $\mathrm{F}^{\mathrm{T}}$. Influence of age and sodium intake on plasma renin activity of normal subjects. Nephron 1980;26(4):189-94.

64. Schling $\mathrm{P}$, Schafer T. Human adipose tissue cells keep tight control on the angiotensin II levels in their vicinity. J Biol Chem 2002;277(50):48066-75. 


\section{4}

Angiotensin II-induced effects on adipose and skeletal muscle tissue blood flow and lipolysis in normalweight and obese subjects

Gijs H. Goossens, Ellen E. Blaak, Wim H.M. Saris and Marleen A. van Baak

Department of Human Biology, Nutrition and Toxicology Research Institute Maastricht (NUTRIM), Maastricht University, Maastricht, The Netherlands

J Clin Endocrinol Metab 2004;89(6):2690-6 


\section{Abstract}

The present study was designed to investigate the effects of angiotensin II (Ang II) on adipose and skeletal muscle tissue blood flow and lipolysis in normal-weight and obese subjects using the microdialysis technique.

Microdialysis probes were placed in the abdominal subcutaneous adipose tissue left and right from the umbilicus and in the gastrocnemius muscle of both legs in eight normal-weight and eight obese men. Probes were consecutively perfused with 1.0 nM Ang II, $1.0 \mu \mathrm{M}$ Ang II and $1.0 \mu \mathrm{M}$ Ang II $+48 \mu \mathrm{M}$ hydralazine or with Ringer solution (control). Ethanol and glycerol concentrations in the dialysate were measured as indicators of local blood flow and lipolysis, tespectively.

Ang II caused an increase in ethanol outflow/inflow ratio compared with baseline values both in adipose tissue (average of both groups, Ang $1.0 \mathrm{nM}$ : $0.03 \pm 0.01$, $P=0.02$; Ang $1.0 \mu \mathrm{M}$ : $0.05 \pm 0.01, P<0.01$ ) and muscle (average of both groups, Ang $1.0 \mathrm{nM}$ : $0.02 \pm 0.01, P=0.09$; Ang $1.0 \mu \mathrm{M}: 0.04 \pm 0.01, P=0.01$ ), indicating a decrease in local blood flow. These effects were not significantly different in obese and normal-weight subjects. The decrease in local blood flow was accompanied by unchanged interstitial glycerol concentrations in adipose tissue (except during the supraphysiological dose) and skeletal muscle, suggesting that Ang II inhibits lipolysis in both tissues.

The present data indicate that Ang II decreases local blood flow in a dosedependent manner and inhibits lipolysis both in adipose tissue and skeletal muscle. These effects were not significantly different in obese compared with normalweight subjects in both tissues. 


\section{Introduction}

The octapeptide angiotensin II (Ang II) is the active component of the reninangiotensin system (RAS). In addition to Ang II synthesis in the circulation, several components of the RAS, like angiotensinogen, renin and angiotensin-converting enzyme, have been identified in a variety of tissues $(1,2)$, implying that these tissues have the ability to synthesize Ang II independently of circulating RAS components. There is accumulating evidence to suggest that a local RAS is present both in adipose and skeletal muscle tissue. However, the physiological role of Ang II in these tissues remains to be established. There is evidence that the RAS in adipose tissue may affect adipocyte growth and differentiation, adipose tissue blood flow, and lipolysis and may be involved in the pathophysiology of obesity and obesity-related disorders, as has been reviewed recently (3).

Findings on the effects of Ang II on tissue blood flow and lipolysis are controversial. Boschmann et al. have shown that Ang II decreased blood flow and inhibited lipolysis in adipose tissue of normal-weight men (4) and women (5). However, they could not confirm these findings in subsequent studies, in which they showed that Ang II had no effect on adipose tissue blood flow and it stimulated rather than inhibited lipolysis in this tissue in normal-weight men (6). In another study in nonobese and obese subjects, Ang II had no effect on adipose and skeletal muscle tissue blood flow in both groups and exerted a lipolytic effect in adipose tissue and an antilipolytic effect in skeletal muscle tissue in nonobese, but not in obese men (7). Finally, it has been demonstrated that intravenous infusion of Ang II reduces forearm blood flow, and locally produced Ang II seemed to be more important for vasoconstriction in the forearm than Ang II delivered via the circulation (8).

Thus, the effects of Ang II on blood flow and lipolysis in adipose and skeletal muscle tissue are not yet fully understood and need to be studied in further detail. In addition, with regard to the possible involvement of Ang II in the pathophysiology of obesity, it is of particular interest to find out whether Ang II exerts different effects on tissue blood flow and lipolysis in normal-weight and obese subjects because it has been shown before that adipose tissue blood flow and lipolysis are disturbed in obese individuals during catecholamine stimulation $(9,10)$. Therefore, the aim of this study was to examine the effects of Ang II on adipose tissue and skeletal muscle blood flow and lipolysis in the fasting state in normal-weight and obese subjects using the microdialysis technique. 


\section{Subjects and methods}

\section{Subjects}

Eight normal-weight $\left(\mathrm{BMI}<25 \mathrm{~kg} / \mathrm{m}^{2}\right)$ and eight obese $\left(\mathrm{BMI}>30 \mathrm{~kg} / \mathrm{m}^{2}\right)$ male subjects participated in this study. Physical characteristics of the subjects are summarized in table 4.1. Body density was determined by hydrostatic weighing after an overnight fast. Lung volume was measured simultaneously with the helium dilution technique using a spirometer (Volugraph 2000, Mijnhardt, Bunnik, The Netherlands). Body weight was measured with a digital balance, accurate to 0.001 kg (type E1200, August Sauter GmbH, Albstadt, Germany). Body fat percentage was calculated using the equation of Siri (11). All subjects were in good health as assessed by medical history and spent no more than $2 \mathrm{~h}$ a week in organized sports activities. The Medical-Ethical Committee of Maastricht University approved the study protocol, and all subjects gave their written informed consent before participating in the study.

Table 4.1 Subjects' characteristics

\begin{tabular}{lll}
\hline & Normal-weight $(n=8)$ & Obese $(n=8)$ \\
\hline Age $(\mathrm{yr})$ & $52 \pm 2$ & $49 \pm 3$ \\
Weight $(\mathrm{kg})$ & $76.6 \pm 2.1$ & $112.8 \pm 6.4^{* *}$ \\
Height $(\mathrm{m})$ & $1.78 \pm 0.03$ & $1.78 \pm 0.02$ \\
BMI $\left(\mathrm{kg} / \mathrm{m}^{2}\right)$ & $24.3 \pm 0.5$ & $35.5 \pm 1.8^{*}$ \\
Body fat $(\%)$ & $22.8 \pm 1.5$ & $34.6 \pm 2.7^{*}$ \\
\hline
\end{tabular}

Unpaired $t$-test, $* P<0.01$ and $" P<0.001$ us. normal-weight. Values are means $\pm S E M$.

\section{Protocol}

All subjects were asked to refrain from drinking alcohol, smoking, and doing strenuous exercise for a period of $24 \mathrm{~h}$ before the study. Subjects came to the laboratory by car or bus in the morning after an overnight fast. On arrival, four microdialysis catheters (CMA 60, CMA microdialysis AB, Stockholm, Sweden) were inserted before the start of the experiment. Microdialysis probes were placed in the abdominal subcutaneous adipose tissue under sterile conditions $6-8 \mathrm{~cm}$ left and right from the umbilicus. One hour before insertion of these probes, the skin was anesthetized by means of a cream containing lidocaine $(25 \mathrm{mg} / \mathrm{g})$ and prilocaine $(25 \mathrm{mg} / \mathrm{g}$ ) (EMLA, AstraZeneca BV, Zoetermeer, The Netherlands). Furthermore, microdialysis probes were inserted in the medial portion of the 
gastrocnemius muscle of both legs after anesthesia (xylocaine $2 \%$ without adrenaline, AstraZeneca BV). Thereafter, $90 \mathrm{~min}$ was allowed for recovery of the skeletal muscle and adipose tissue from the insertion trauma.

The probes $\left(30 \times 0.6 \mathrm{~mm}^{2}\right.$, molecular weight cutt-off of 20,000$)$ consisted of a dialysis tubing glued to the end of a double-lumen polyurethane cannula. The perfusion solvent enters the probe through the inner cannula, passes down to the tip of the probe, streams upward in the space between the inner cannula and the outer dialysis membrane and leaves the probe through the outer cannula via a side arm from which it is collected in a capped microvial.

After insertion, all probes were perfused with Ringer solution $147 \mathrm{mM}$ sodium, 4 $\mathrm{mM}$ potassium, $2.25 \mathrm{mM}$ calcium, and $156 \mathrm{mM}$ chloride, Baxter BV, Utrecht, The Netherlands), supplemented with $50 \mathrm{mM}$ ethanol, at a flow rate of $0.5 \mu \mathrm{L} / \mathrm{min}$ (Harvard microinfusion pump, Plato BV, Diemen, The Netherlands). After $90 \mathrm{~min}$ recovery, the real interstitial glycerol concentration was determined individually by means of the zero flow method $(12,13)$ (see 'Zero flow method'). Microdialysate was collected in two 20 -min fractions at a flow rate of $0.5 \mu \mathrm{l} / \mathrm{min}$ and in three 10 min fractions at flow rates of $1.0,2.5$, and $5.0 \mu \mathrm{l} / \mathrm{min}$. The calibration period with a flow rate of $5.0 \mu \mathrm{l} / \mathrm{min}$ was used as baseline measurement for the second part of the experiment.

During the second part of the experiment, the experimental probes in adipose tissue and skeletal muscle were consecutively perfused with $1.0 \mathrm{nM}$ Ang II (Ang $1.0 \mathrm{nM}$ ), $1.0 \mu \mathrm{M}$ Ang II (Ang $1.0 \mu \mathrm{M}$ ) and $1.0 \mu \mathrm{M}$ Ang II $+48 \mu \mathrm{M}$ hydralazine (Ang $1.0 \mu \mathrm{M}+\mathrm{H}$ ), each dose for $60 \mathrm{~min}$ at a flow rate of $5.0 \mu \mathrm{l} / \mathrm{min}$, to examine the effect of Ang II on local blood flow and lipolysis (ethanol and glycerol concentrations in the dialysate, respectively). The highest perfusion dose of Ang II was also administered in combination with the vasodilatator hydralazine to counteract the possible Ang II-induced vasoconstriction and, therefore, to distinguish between the possible direct and blood flow-mediated effects of Ang II on the interstitial glycerol concentration. The other probes in adipose tissue and skeletal muscle served as control probes and were perfused with Ringer solution ( $+50 \mathrm{mM}$ ethanol) at a similar perfusion rate during the whole experiment. There was a wash-out period of $30 \mathrm{~min}$ perfusion with Ringer solution ( $+50 \mathrm{mM}$ ethanol) between each perfusion step (figure 4.1).

Microdialysate was collected in fractions corresponding to 10 min during the second part of the experiment. In all samples collected at flow rates of $0.5,1.0$, and $2.5 \mu \mathrm{l} / \mathrm{min}$, dialysate glycerol concentration was measured. Both dialysate glycerol 


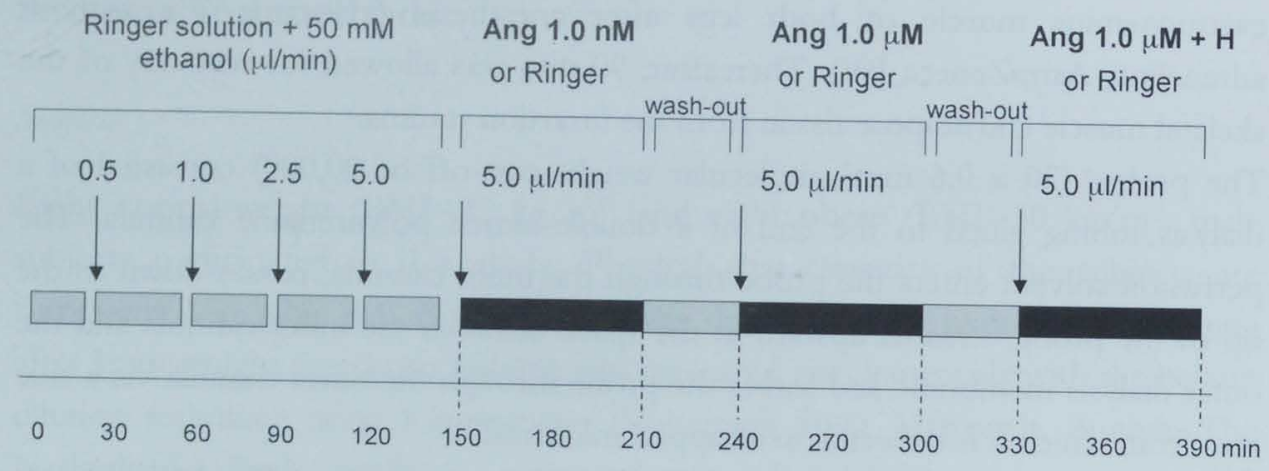

Figure 4.1 Experimental design.

and ethanol concentrations were determined in all other samples. Furthermore, ethanol concentration was determined both in the ingoing and outgoing perfusion solvent to assess the ethanol outflow/inflow (out/in) ratio as an indicator of local nutritive blood flow (ethanol dilution technique) $(14,15)$. The interstitial glycerol concentration was used to assess changes in lipolysis. Ethanol concentrations were determined the same day, whereas the samples for measurement of the interstitial glycerol concentration were immediately frozen in liquid nitrogen and stored at $-80^{\circ} \mathrm{C}$ until analysis. All changes in ethanol out/in ratios and glycerol concentrations observed in the different experimental conditions were adjusted for corresponding changes in the control probes to take into account changes over time in tissue blood flow and lipolysis that were not due to the intervention. These adjustments were made by subtracting changes in the experimental probes by changes in the control probes. Adjusted values are presented as changes from baseline values because of the interindividual variations in baseline concentrations.

\section{Zero flow method}

During the first part of the experiment, the real interstitial glycerol concentration was determined by means of the zero flow method $(12,13)$. Therefore, the microdialysis probes were perfused with Ringer solution at a flow rate of 0.5 $\mu \mathrm{l} / \mathrm{min}$ for $40 \mathrm{~min}$ and at consecutive flow rates of $1.0,2.5$, and $5.0 \mu \mathrm{l} / \mathrm{min}$ for 30 min. Dialysate glycerol concentrations were $\log$ transformed and plotted against perfusion rates. Linear regression analysis was used to calculate the glycerol concentration at zero flow rate, corresponding to the real interstitial glycerol concentration. The ratio between the dialysate glycerol concentration at $5.0 \mu \mathrm{l} / \mathrm{min}$ 
and the calculated interstitial glycerol concentration represents the in vivo recovery of the probe, and all dialysate glycerol samples collected during the second part of the experiment were adjusted for the in vivo recovery of the corresponding probe.

\section{Analyses}

Glycerol and ethanol concentrations were determined on a Cobas Fara centrifugal analyzer (Roche Diagnostica, Basel, Switzerland). Glycerol concentration was measured fluorometrically using a standard glycerol kit (Boehringer, Mannheim, Germany), but with adjusted concentrations of NADH, enzymes and buffer, to achieve accurate fluorometric detection. Ethanol concentration was measured spectrophotometrically at a wavelength of $340 \mathrm{~nm}$ using a standard ethanol kit (176290, Boehringer).

\section{Statistical analysis}

Data are presented as mean \pm standard error of the mean (SEM). To compare the effects of the different perfusion solvents within and between groups, a repeatedmeasures ANOVA was performed. Post hoc testing was performed using Student's paired or unpaired $t$-tests. Calculations were done using Statview 5.0 for iMac. $P<0.05$ was considered to be statistically significant.

\section{Results}

By definition, obese men had a significantly higher body weight, body mass index, and body fat percentage, compared with normal-weight men. Age and height of both groups were similar (table 4.1).

\section{Ethanol out/in ratio}

At baseline, ethanol out/in ratios were not significantly different in obese, compared with normal-weight subjects, both in adipose tissue [average of experimental and control probe: $0.84 \pm 0.07$ (obese) vs. $0.79 \pm 0.10$ (normal-weight), $P=0.17$ ] and muscle [average of experimental and control probe: $0.51 \pm 0.08$ (obese) vs. $0.46 \pm 0.06$ (normal-weight), $P=0.10$ ] (figure 4.2, $\mathrm{A}$ and $\mathrm{B}$ ). As expected, baseline ethanol out/in ratios were higher in adipose tissue than in skeletal muscle in both groups, reflecting a lower blood flow in abdominal subcutaneous adipose tissue, compared with skeletal muscle. 
During perfusion with Ang II, there was a significant dose-dependent increase in ethanol out/in ratios as compared to baseline values both in adipose tissue (average of both groups, Ang $1.0 \mathrm{nM}$ : $0.03 \pm 0.01, P=0.02$; Ang $1.0 \mu \mathrm{M}$ : $0.05 \pm 0.01$, $P<0.01$ ) and muscle (average of both groups, Ang $1.0 \mathrm{nM}$ : 0.02 $\pm 0.01, P=0.09$; Ang $1.0 \mu \mathrm{M}: 0.04 \pm 0.01, P=0.01$ ) (figure $4.2, C$ and $D$ ), indicating a decrease in local nutritive blood flow in both tissues. At the lowest (physiological) dose of Ang II, the increase in ethanol out/in ratios from baseline was $0.04 \pm 0.01(P=0.01)$ and $0.02 \pm 0.02$ (NS) in adipose tissue and $0.03 \pm 0.01(P=0.08)$ and $0.01 \pm 0.01(N S)$ in skeletal muscle in obese and normal-weight subjects, respectively. However, the differences in increase from baseline between groups did not reach statistical significance. When expressed as percentage increase in ethanol out/in ratio, similar results were obtained (data not shown).

In adipose as well as skeletal muscle tissue, perfusion with $1.0 \mu \mathrm{M}$ Ang II $+48 \mu \mathrm{M}$ hydralazine (Ang $1.0 \mu \mathrm{M}+\mathrm{H}$ ) significantly lowered ethanol out/in ratios, compared with perfusion with the highest dose of Ang II alone (average of both groups: $-0.05 \pm 0.02, P=0.01$ vs. $-0.12 \pm 0.01, P<0.001$, respectively), indicating an increase in local blood flow. Compared with baseline values, perfusion with Ang $1.0 \mu \mathrm{M}+\mathrm{H}$ decreased ethanol out/in ratios in muscle (average of both groups: $-0.08 \pm 0.01$, $P<0.001$ ), but did not significantly change ethanol out/in ratios in adipose tissue of both groups.

\section{Interstitial glycerol concentration}

Baseline interstitial glycerol concentrations in adipose tissue were not significantly different in obese as compared to normal-wcight subjects (average of experimental and control probe: $197 \pm 108$ (obese) vs. $148 \pm 65 \mu \mathrm{M}$ (normal weight), $P=0.14$ ) (figure $4.3 \mathrm{~A}$ ). Interstitial glycerol concentration in skeletal muscle of obese subjects was significantly higher than that of normal-weight subjects under baseline conditions (average of experimental and control probe: $103 \pm 28$ (obese) vs. $84 \pm 19$ $\mu \mathrm{M}$ (normal-weight), $P=0.04$ ) (figure 4.3B). As expected, baseline interstitial glycerol concentrations were higher in adipose tissue than in skeletal muscle in both groups. In adipose tissue, the only significant change in interstitial glycerol concentration from baseline was found during perfusion with Ang $1.0 \mu \mathrm{M}$ (average of both groups: $51.3 \pm 20.2 \mu \mathrm{M}, P=0.02$ ) (figure 4.3C). This increase from baseline was $42.1 \pm 30.9 \mu \mathrm{M}$ (NS) in obese and $59.4 \pm 28.2 \mu \mathrm{M}(P=0.07)$ in normal-weight subjects. However, the differences in increase from baseline between groups did 

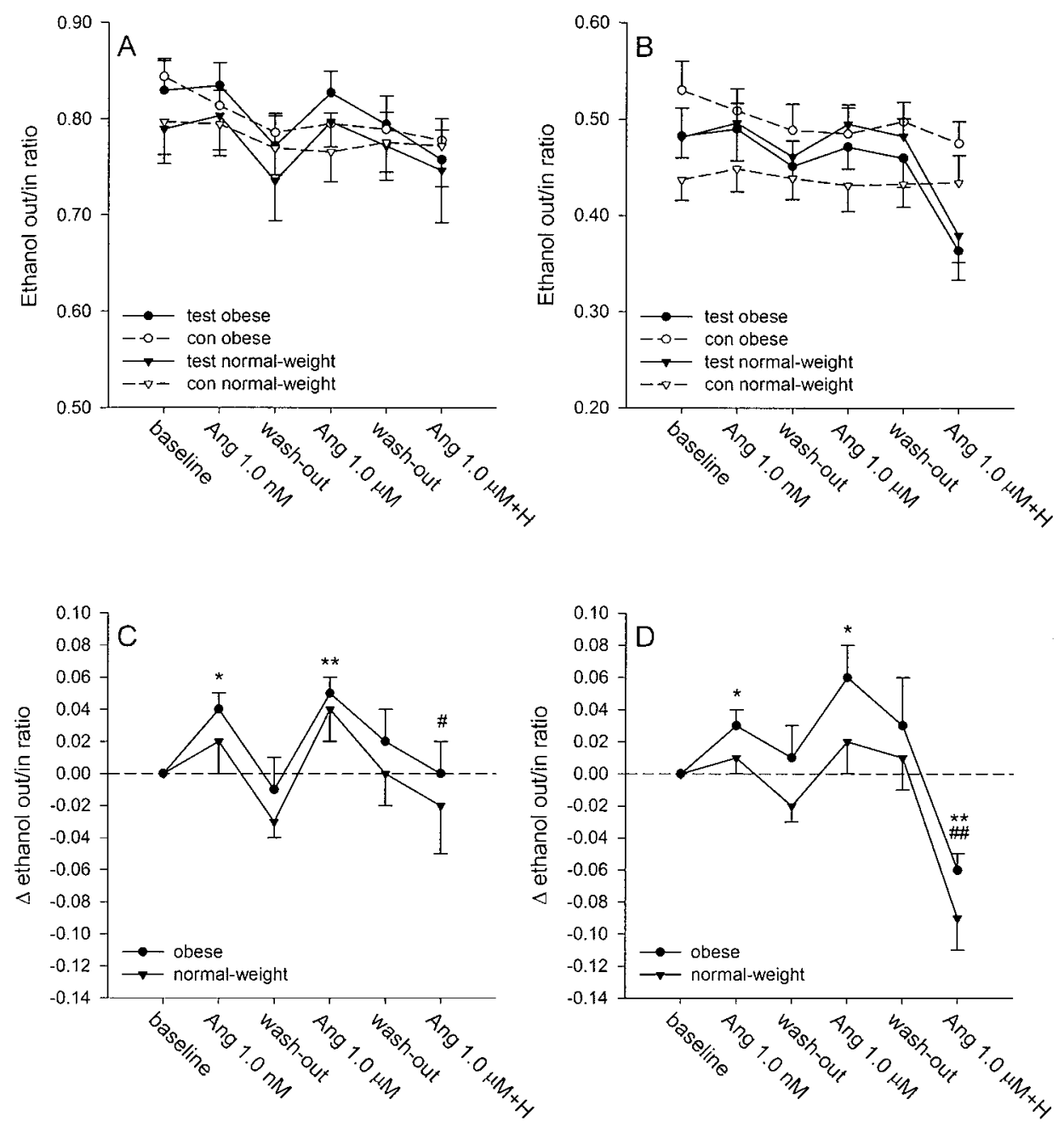

Figure 4.2 Effects of Ang II on the ethanol out/in ratio in abdominal subcutaneous adipose tissuc (A) and skeletal muscle (B) in eight normal-weight and cight obese subjects. Data are adjusted for corresponding changes in the control probes and presented as changes from baseline values in adipose tissue (C) and skeletal muscle (D). ${ }^{*} P<0.05$ vs. baseline, ${ }^{* *} P<0.01$ vs. baseline, ${ }^{*} P<0.05$ vs. Ang $1.0 \mu \mathrm{M}, \# P<0.001 \nu$ s. Ang $1.0 \mu \mathrm{M}$. Values are means $\pm \mathrm{SEM}$.

not reach statistical significance. In skeletal muscle, the only significant change in interstitial glycerol concentration from baseline was observed during perfusion with Ang $1.0 \mu \mathrm{M}+\mathrm{H}$ (average of both groups: $19.1 \pm 8.8 \mu \mathrm{M}, P<0.05$ ) (figure $4.3 \mathrm{D}$ ). When expressed as percentage increase in interstitial glycerol concentration, similar results were obtained (data not shown). 

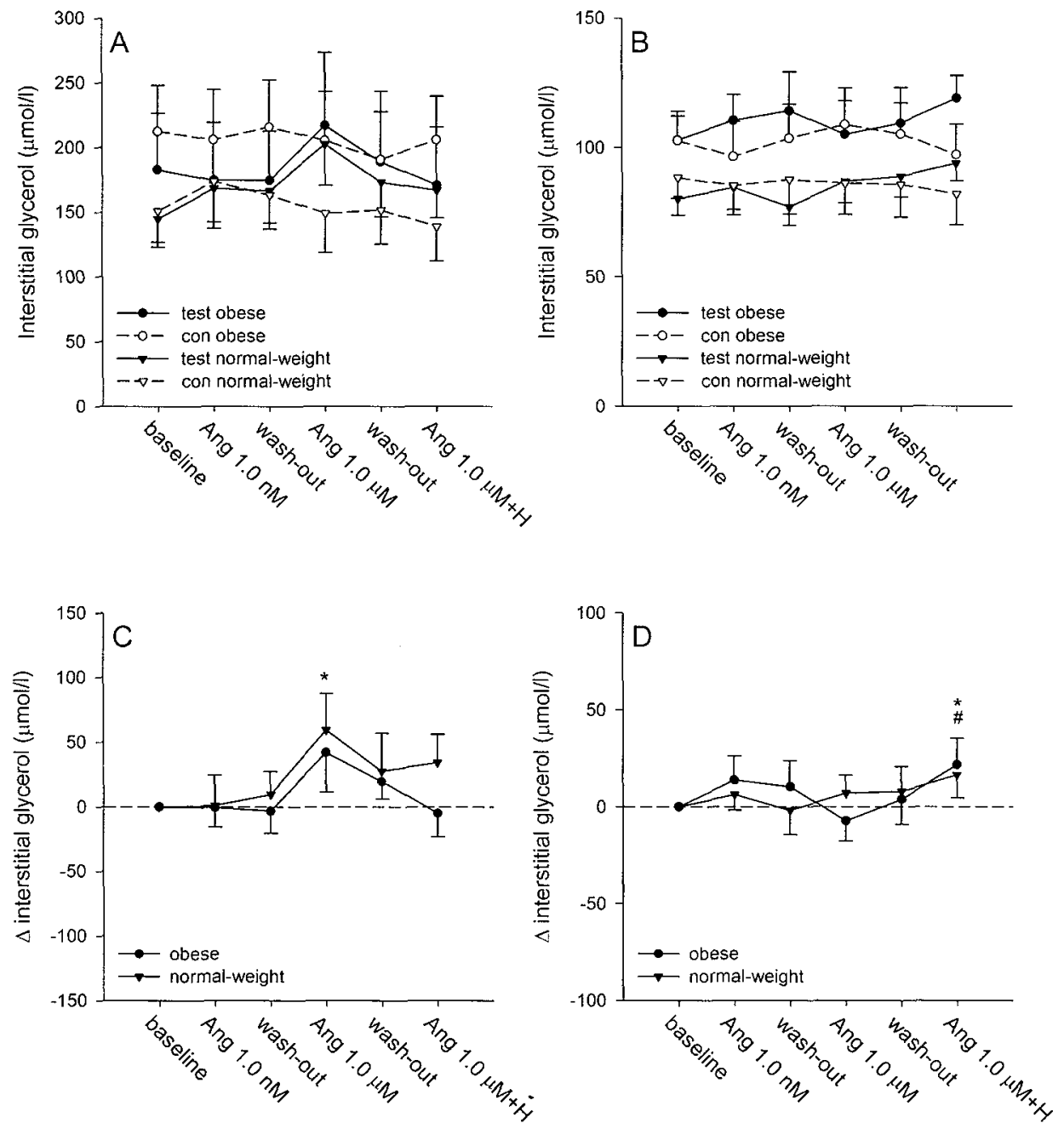

Figure 4.3 Effects of Ang II on the interstitial glycerol concentration in abdominal subcutaneous adipose tissue (A) and skeletal muscle (B) in eight normal-weight and eight obese subjects. Data are adjusted for corresponding changes in the control probes and presented as changes from baseline values in adipose tissue (C) and skeletal muscle (D). ${ }^{*} P<0.05 v$ s. baseline and $\# P<0.05 v s$. Ang $1.0 \mu \mathrm{M}$. Values are means \pm SEM.

\section{Discussion}

It is tempting to postulate that in addition to Ang II produced in the circulation, locally produced Ang II may affect local nutritive blood flow and lipolysis in adipose tissue and skeletal muscle, and may thereby affect fat accumulation in 
these tissues. However, the physiological significance of Ang II in these processes remains to be established.

\section{Local blood flow and lipolysis}

The present data show that Ang II stimulation in situ causes an increase in ethanol out/in ratios both in adipose tissue and skeletal muscle, indicating a decrease in local blood flow. This finding is in agreement with the well-known vasoconstrictive effect of Ang II in the systemic circulation and its role in elevating blood pressure (16). The decrease in blood flow in both tissues was not significantly different in obese and normal-weight subjects. Inhibition of local blood flow will retain glycerol in the tissue (17), thereby increasing the interstitial glycerol concentration due to product accumulation. However, the Ang II-induced reduction in blood flow was accompanied by interstitial glycerol concentrations that were not different from baseline values in adipose tissue and skeletal muscle during stimulation with the lower dose of Ang II (1.0 nM), suggesting that Ang II inhibits lipolysis in both tissues. The elevation in glycerol concentration in the dialysate observed when adipose tissue was stimulated with the highest (supraphysiological) dose of Ang II, despite an Ang II-induced inhibition of lipolysis, might be explained by the extra vasoconstriction that occurred. However, we cannot exclude that Ang II stimulation in situ may cause a dose-dependent biphasic response, with an antilipolytic effect of Ang II at physiological concentrations, and no effect or a lipolytic effect at supraphysiological concentrations.

The normal concentration of Ang II in plasma is about $10 \mathrm{pM}$ (18). However, it should be mentioned that local Ang II production might result in higher Ang II concentrations in the interstitial space than in the circulation. For example, Ang II concentration in the interstitial space of the rat kidney has been shown to be about 30-fold higher than the circulating Ang II concentration (19). In addition, with the present perfusion rate only a small fraction (probably less than 20\%) of Ang II in the perfusate will diffuse into the interstitial space. Therefore, the lowest dose of Ang II used in the present study $(1.0 \mathrm{nM})$ most likely corresponds to an interstitial Ang II concentration that is within the physiological range.

In line with our findings, others have found that Ang II reduces blood flow and inhibits lipolysis in adipose tissue of normal-weight men (4) and women (5). However, they could not confirm these findings in subsequent studies, in which they showed that Ang II had no effect on adipose and skeletal muscle tissue blood flow, and it stimulated rather than inhibited lipolysis in adipose tissue, whereas it 
inhibited lipolysis in muscle in normal-weight men (6). In a recent study, Ang II had no effect on adipose tissue and skeletal muscle blood flow in nonobese and obese subjects and exerted a lipolytic effect in adipose tissue and an antilipolytic effect in skeletal muscle in nonobese but not in obese men (7). In contrary to the above-mentioned studies, control probes were used in the present study to take into account changes over time in tissue blood flow and lipolysis that were not due to the intervention. Additionally, the nonobese and obese subjects in the present study were well-matched for age, which was not the case in the study of Boschmann et al. (7). Furthermore, a wash-out period of $30 \mathrm{~min}$ perfusion with Ringer solution between each perfusion step was included in our design to prevent that Ang II applied in a previous perfusion step would affect the following condition.

During perfusion with the highest dose of Ang II in combination with the vasodilating agent hydralazine (Ang $1.0 \mu \mathrm{M}+\mathrm{H}$ ) in muscle, local blood flow was tremendously increased, and the interstitial glycerol concentration was significantly elevated, compared with the highest dose of Ang II alone, indicating that hydralazine itself exerts a strong lipolytic effect in skeletal muscle. During perfusion with Ang $1.0 \mu \mathrm{M}+\mathrm{H}$ in adipose tissue, blood flow and interstitial glycerol concentration were not significantly different from baseline. Because of the antilipolytic effect of Ang II in adipose tissue, this suggests that hydralazine also stimulates lipolysis in adipose tissue, although this effect is less clear than in skeletal muscle. Indeed, there is some indirect evidence that strengthens our observations. In vascular smooth muscle cells, the main action of hydralazine is to inhibit the inositol 1,4,5-triphosphate-induced release of $\mathrm{Ca}^{2+}$ from the sarcoplasmic reticulum (20). Interestingly, increasing intracellular $\mathrm{Ca}^{2+}$ inhibits lipolysis in a dose-dependent manner in rat adipocytes (21). In line with this, the agouti gene product inhibits lipolysis in human adipocytes via an increase in intracellular $\mathrm{Ca}^{2+}(22)$. Thus, low concentrations of intracellular $\mathrm{Ca}^{2+}$ may stimulate lipolysis. Therefore, hydralazine may lead to an increased rate of lipolysis by inhibiting the inositol 1,4,5-triphosphate-induced release of $\mathrm{Ca}^{2+}$ into the cytosol in invo.

\section{Underlying mechanisms for the antilipolytic effect}

Although less is known about the physiological effects of Ang II on adipose tissue and skeletal muscle lipolysis, there are mechanisms that may explain the antilipolytic effect of Ang II found in the present study. There is evidence that Ang II may act on the sympathetic nervous system. Under resting conditions, lipolysis 
is primarily regulated (inhibited) by the activity of $\alpha_{2}$-adrenergic receptors $(23,24)$, and it has been demonstrated that Ang II augments the release of noradrenaline from brown adipose tissue sympathetic nerve terminals (25). Thus, the antilipolytic effects of Ang II observed in the present study may be due to stimulation or potentiation of $\alpha_{2}$-adrenergic activity. In addition, it has been demonstrated that binding of Ang II to the angiotensin type 1 receptor inhibits adenylate cyclase in smooth muscle cells, the kidney and hepatocytes $(26,27)$. Therefore, Ang II might inhibit adenylate cyclase in adipose and skeletal muscle tissue as well, which in turn may cause an inhibition of lipolysis (28). In this respect, a novel pathway controlling human adipose tissue lipolysis has been discovered recently. It was demonstrated that atrial natriuretic peptide (ANP) exerted a lipolytic effect via a cGMP-dependent pathway in human adipocytes (29). Interestingly, Ang II has been shown to counteract the ANP-stimulated cGMP synthesis in cultured podocytes (30) and glomerular mesangial cells (31). Therefore, it may be that Ang II inhibits lipolysis in adipose and skeletal muscle tissue by inhibiting the ANPstimulated cGMP synthesis. Furthermore, Ang II has been shown to increase the intracellular $\mathrm{Ca}^{2+}$ concentration in pancreatic (32) and vascular smooth muscle cells (33). Taking into account the finding that increasing intracellular $\mathrm{Ca}^{2+}$ inhibited lipolysis $(21,22)$, it may be that the Ang II-induced antilipolytic effect in adipose and skeletal muscle tissue observed in the present study was caused by an increase in the intracellular $\mathrm{Ca}^{2+}$ concentration in these tissues.

\section{Role of Ang II in obesity}

The Ang II-induced effects on adipose tissue and skeletal muscle blood flow and lipolysis are not significantly different between obese and normal-weight subjects. However, the tendency toward a small difference in tissue blood flow and lipolysis between groups warrants further research to substantiate these results. Because there is evidence for the existence of a local RAS in adipose tissue (3), it is tempting to speculate that higher Ang II formation in adipose tissue of obese subjects may contribute to fat accumulation in adipose tissue and skeletal muscle in these individuals. Interestingly, fat accumulation in skeletal muscle is negatively associated with insulin sensitivity in obese and type 2 diabetic subjects $(34,35)$. However, further studies are necessary because even if Ang II production in adipose tissue is elevated in obese subjects, it may be that higher Ang II concentrations lead to downregulation of Ang II responsiveness. Furthermore, Ang II may be, at least in part, responsible for the reported lower basal adipose tissue blood flow in obese compared with lean subjects $(9,36-38)$ and may explain 
the significantly increased basal adipose tissue blood flow observed after weight reduction (9).

\section{Conclusions}

The present data suggest that Ang II stimulation in situ decreases local blood flow in a dose-dependent manner and inhibits lipolysis in both adipose tissue and skeletal muscle. These effects were not significantly different between obese and normal-weight subjects in both tissues. Furthermore, our data suggest that the vasodilatator hydralazine exerts a lipolytic effect in skeletal muscle and adipose tissue, although this effect is less clear in the latter tissue.

\section{Acknowledgements}

The authors thank Jos Stegen for his excellent technical assistance with the analysis of dialysate samples.

\section{References}

1. Phillips MI, Speakman EA, Kimura B. Levels of angiotensin and molecular biology of the tissue renin angiotensin systems. Regul Pept 1993;43(1-2):1-20.

2. Schling P, Mallow $H$, Trindl A, Loffler $G$. Evidence for a local renin angiotensin system in primary cultured human preadipocytes. Int J Obes Relat Metab Disord 1999;23(4):336-41.

3. Goossens GH, Blaak EE, van Baak MA. Possible involvement of the adipose tissue reninangiotensin system in the pathophysiology of obesity and obesity-related disorders. Obes Rev 2003;4(1):43-55.

4. Boschmann M, Ringel J, Klaus S, Sharma AM. Metabolic and hemodynamic response of adipose tissue to angiotensin II. Obes Res 2001;9(8):486-91.

5. Boschmann M, Jordan J, Schmidt S, Adams F, Luft FC, Klaus S. Gender-Specific Response to Interstitial Angiotensin II in Human White Adipose Tissue. Horm Metab Res 2002;34(1112):726-30.

6. Boschmann M, Jordan J, Adams F, Christensen NJ, Tank J, Franke G, et al. Tissue-specific response to interstitial angiotensin II in humans. Hypertension 2003;41(1):37-41.

7. Boschmann $\mathrm{M}$, Adams F, Klaus S, Sharma AM, Luft $\mathrm{l}^{7} \mathrm{C}$, Jordan J. Differential response to interstitial angiotensin II in normal weight and obese men. Int J Obes Relat Metab Disord $2003 ; 27(1):$ S52.

8. Saris JJ, van Dijk MA, Kroon I, Schalekamp MA, Danser AH. Functional importance of angiotensin-converting enzyme-dependent in situ angiotensin II generation in the human forearm. Hypertension 2000;35(3):764-8.

9. Blaak EE, van Baak MA, Kemerink GJ, Pakbiers MT, Heidendal GA, Saris WH. Betaadrenergic stimulation and abdominal subcutaneous fat blood flow in lean, obese, and reducedobese subjects. Metabolism 1995;44(2):183-7.

10. Blaak EE, Van Baak MA, Kemerink GJ, Pakbiers MT, Heidendal GA, Saris WH. Betaadrenergic stimulation of energy expenditure and forearm skeletal muscle metabolism in lean and obese men. Am J Physiol 1994;267(2 Pt 1):E306-15.

11. Siri WE. The gross composition of the body. Adv Biol Med Physiol 1956;4:239-280. 
12. Boutelle MG, Fillenz M. Clinical microdialysis: the role of on-line measurement and quantitative microdialysis. Acta Neurochir Suppl 1996;67:13-20.

13. Stahle L, Segersvard S, Ungerstedt U. A comparison between three methods for estimation of extracellular concentrations of exogenous and endogenous compounds by microdialysis. J Pharmacol Methods 1991;25(1):41-52.

14. Arner $\mathrm{P}$, Bulow $\mathrm{J}$. Assessment of adipose tissue metabolism in man: comparison of Fick and microdialysis techniques. Clin Sci (Lond) 1993;85(3):247-56.

15. Hickner RC, Rosdahl H, Borg I, Ungerstedt U, Jorfeldt L, Henriksson J. Ethanol may be used with the microdialysis technique to monitor blood flow changes in skeletal muscle: dialysate glucose concentration is blood-flow-dependent. Acta Physiol Scand 1991;143(3):355-6.

16. Timmermans PB, Wong PC, Chiu AT, Herblin WF, Benfield P, Carini DJ, et al. Angiotensin II receptors and angiotensin II receptor antagonists. Pharmacol Rev 1993;45(2):205-51.

17. Enoksson S, Nordenstrom J, Bolinder J, Amer P. Influence of local blood flow on glycerol levels in human adipose tissue. Int J Obes Relat Metab Disord 1995;19(5):350-4.

18. Campbell DJ, Kladis $A$. Simultaneous radioimmunoassay of six angiotensin peptides in arterial and venous plasma of man. J Hypertens 1990;8(2):165-72.

19. Nishiyama $A$, Seth DM, Navar LG. Renal interstitial fluid concentrations of angiotensins I and II in anesthetized rats. Hypertension 2002;39(1):129-34.

20. Ellershaw DC, Gurney AM. Mechanisms of hydralazine induced vasodilation in rabbit aorta and pulmonary artery. Br J Pharmacol 2001;134(3):621-31.

21. Tebar F, Soley M, Ramirez I. The antilipolytic effects of insulin and epidermal growth factor in rat adipocytes are mediated by different mechanisms. Endocrinology 1996;137(10):4181-8.

22. Xue B, Moustaid N, Wilkison WO, Zemel MB. The agouti gene product inhibits lipolysis in human adipocytes via a $\mathrm{Ca}^{2+}$-dependent mechanism. Faseb J 1998;12(13):1391-6.

23. Amer P. Differences in lipolysis between human subcutaneous and omental adipose tissues. Ann Med 1995;27(4):435-8.

24. Leibel RL, Edens NK, Fried SK. Physiologic basis for the control of body fat distribution in humans. Annu Rev Nutr 1989;9:417-43.

25. English V, Cassis L. Facilitation of sympathetic neurotransmission contributes to angiotensin regulation of body weight. J Neural Transm 1999;106(7-8):631-44.

26. Ardaillou R. Angiotensin II receptors. J Am Soc Nephrol 1999;10 Suppl 11:S30-9.

27. Klett C, Nobiling R, Gierschik P, Hackenthal E. Angiotensin II stimulates the synthesis of angiotensinogen in hepatocytes by inhibiting adenylylcyclase activity and stabilizing angiotensinogen mRNA. J Biol Chem 1993;268(33):25095-107.

28. Lafontan M, Berlan M. Fat cell adrenergic receptors and the control of white and brown fat cell function. J Lipid Res 1993;34(7):1057-91.

29. Sengenes C, Berlan M, De Glisezinski I, Lafontan M, Galitzky J. Natriuretic peptides: a new lipolytic pathway in human adipocytes. Faseb J 2000;14(10):1345-51.

30. Golos M, Lcwko B, Bryl E, Witkowski JM, Dubanicwicz A, Olszewska A, et al. Effect of angiotensin II on ANP-dependent guanylyl cyclase activity in cultured mouse and rat podocytes. Kidncy Blood Press Res 2002;25(5):296-302.

31. Haneda M, Kikkawa R, Maeda S, Togawa M, Koya D, Horide N, et al. Dual mechanism of angiotensin II inhibits ANP-induced mesangial cGMP accumulation. Kidney Int $1991 ; 40(2): 188-94$.

32. Chappell MC, Jacobsen DW, Tallant EA. Characterization of angiotensin II receptor subtypes in pancreatic acinar $A R 42 J$ cells. Peptides 1995;16(4):741-7.

33. Touyz RM, Schiffrin EL. Signal transduction mechanisms mediating the physiological and pathophysiological actions of angiotensin II in vascular smooth muscle cells. Pharmacol Rev 2000;52(4):639-72.

34. Mayerson AB, Hundal RS, Dufour S, Lebon V, Befroy D, Cline GW, et al. The effects of rosiglitazone on insulin sensitivity, lipolysis, and hepatic and skeletal muscle triglyceride content in patients with type 2 diabetes. Diabetes 2002;51(3):797-802.

35. Sinha R, Dufout S, Petersen KF, LeBon V, Enoksson S, Ma YZ, et al. Assessment of skeletal muscle triglyceride content by (1) $\mathrm{H}$ nucleat magnetic resonance spectroscopy in lean and obese adolescents: relationships to insulin sensitivity, total body fat, and central adiposity. Diabetes 2002;51(4):1022-7. 
36. Engfeldt $\mathrm{P}$, Linde B. Subcutaneous adipose tissue blood flow in the abdominal and femoral regions in obese women: effect of fasting. Int J Obes Relat Metab Disord 1992;16(11):875-9.

37. Jansson PA, Larsson A, Smith $U$, Lonnroth P. Glycerol production in subcutaneous adipose tissuc in lean and obese humans. J Clin Invest 1992;89(5):1610-7.

38. Summers LK, Samra JS, Humphreys SM, Morris RJ, Frayn KN. Subcutaneous abdominal adipose tissue blood flow: variation within and between subjects and relationship to obesity. Clin Sci (Lond) 1996;91(6):679-83. 


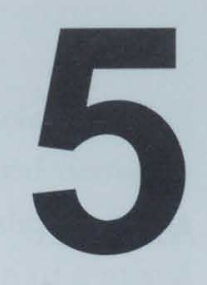

\section{Angiotensin II: a major regulator of} subcutaneous adipose tissue blood flow in humans

Gijs H. Goossens ${ }^{1,2}$, Siobhan E. McQuaid ${ }^{2}$, Louise Dennis ${ }^{2}$, Marleen A. van Baak ${ }^{1}$, Ellen E. Blaak ${ }^{1}$, Keith N. Frayn $^{2}$, Wim H.M. Saris ${ }^{1}$ and Fredrik Karpe ${ }^{2}$

${ }^{1}$ Department of Human Biology, Nutrition and Toxicology Research Institute Maastricht (NUTRIM), Maastricht University, Maastricht, The Netherlands ${ }^{2}$ Oxford Centre for Diabetes, Endocrinology and Metabolism, Nuffield Department of Clinical Medicine, University of Oxford, Oxford, UK

J Physiol 2006;571(2):451-60 


\section{Abstract}

We investigated the functional roles of circulating and locally produced angiotensin II (Ang II) in fasting and postprandial adipose tissue blood flow (ATBF) regulation and examined the interaction between Ang II and nitric oxide (NO) in ATBF regulation.

Local effects of the pharmacological agents (or contralateral saline) on ATBF, measured with ${ }^{133} \mathrm{Xe}$ wash-out, were assessed using the recently developed microinfusion technique. Fasting and postprandial ( $75 \mathrm{~g}$ glucose challenge) ATBF regulation was investigated in nine lean healthy subjects (age, $29 \pm 3 \mathrm{yr} ; \mathrm{BMI}$, $\left.23.4 \pm 0.7 \mathrm{~kg} / \mathrm{m}^{2}\right)$ using local Ang II stimulation, Ang II type $1\left(\mathrm{AT}_{1}\right)$ receptor blockade, and angiotensin-converting enzyme (ACE) inhibition. Furthermore, NO synthase (NOS) blockade alone and in combination with $\mathrm{AT}_{1}$ receptor blockade was used to examine the interaction between Ang II and NO.

Ang II induced a dose-dependent decrease in ATBF $\left(10^{-9} \mathrm{M}:-16 \%, P=0.04\right.$; $\left.10^{-7} \mathrm{M}:-33 \%, P<0.01 ; 10^{-5} \mathrm{M}:-53 \% P<0.01\right)$. Fasting ATBF was not affected by ACE inhibition, but was increased by $\sim 55 \%(P<0.01)$ by $\mathrm{AT}_{1}$ receptor blockade. NOS blockade induced a $\sim 30 \%(P=0.001)$ decrease in fasting ATBF. Combined $\mathrm{AT}_{1}$ receptor and NOS blockade increased ATBF by $\sim 40 \%(P=0.003)$. ACE inhibition and $A T_{1}$ receptor blockade did not affect the postprandial increase in ATBF.

We therefore conclude that circulating Ang II is a major regulator of fasting ATBF, and a major proportion of the Ang II-induced decrease in ATBF is NO independent. Locally produced Ang II does not appear to regulate ATBF. Ang II appears to have no major effect on the postprandial enhancement of ATBF. 


\section{Introduction}

Tissue-specific regulation of blood flow in tissues such as skeletal muscle, liver and adipose tissue is needed to meet the local metabolic and physiological demands under varying conditions. Previous studies have clearly shown that adipose tissue blood flow (ATBF) is increased after glucose intake (1) or the ingestion of a mixed meal (2), whereas fat intake alone does not evoke a blood flow response (3). The ATBF response to nutrient intake may be of great importance in the regulation of metabolism by facilitating signalling between adipose tissue and other tissues, such as skeletal muscle and liver (4). For example, it has been shown that the extraction of plasma triacylglycerol is elevated with increasing ATBF (5).

Both fasting ATBF (6-8) and ATBF responsiveness to nutrients $(6,7)$ are reduced in obesity, and this impairment is associated with insulin resistance $(6,9)$. Although insulin itself does not seem to be the actual stimulus for this nutrient-related elevation of ATBF (10), it has been demonstrated that the postprandial enhancement of ATBF coincides with an increased plasma insulin concentration and suppression of circulating non-esterified fatty acids (NEFA) (2). There is abundant evidence that $\beta$-adrenergic stimulation elevates $\mathrm{ATBF}(8,11-13)$ and it has recently been shown that a major proportion of the postprandial enhancement of ATBF results from local $\beta$-adrenergic stimulation (14), which may be secondary to the postprandial increase in insulin concentrations that might activate the sympathetic nervous system (10). Furthermore, nitric oxide (NO) seems to be involved in fasting ATBF regulation (14).

There is evidence for a local angiotensin II (Ang II) generating system in adipose tissue (15-19), implying that the vasoactive component Ang II may be produced in adipose tissue. Local Ang II stimulation using the microdialysis technique decreased fasting nutritive blood flow and inhibited lipolysis in abdominal subcutaneous adipose tissue and skeletal muscle in normal-weight and obese subjects (20). However, the functional importance of locally produced Ang II in adipose tissue and circulating Ang II and their role in postprandial ATBF regulation have never been assessed. In addition, there is evidence that Ang II increases oxidative stress and interacts with NO function, leading to endothelial dysfunction (21). This suggests that there could be an interaction between Ang II and NO in the Ang II-induced effect on ATBF.

Therefore, we used a pharmacological approach, using local Ang II stimulation, Ang II type $1\left(\mathrm{AT}_{1}\right)$ receptor blockade, and ACE inhibition, to investigate whether 
locally produced and circulating Ang II decrease ATBF both under fasting and postprandial conditions. We also examined the contribution of NO to the Ang IIinduced effect on ATBF using NO synthase (NOS) blockade. To accomplish this, the recently developed microinfusion technique was used, which makes semiquantitative assessment of the local effects of vasoactive compounds on ATBF possible (10). With the model used in the present study, we are to our knowledge the first to determine the relative contribution of locally produced Ang II in adipose tissue and circulating Ang II that reaches adipose tissue to an Ang IIinduced effect in this tissue.

\section{Methods}

\section{Subjects}

Nine lean healthy non-smoking volunteers (5 female) free of any medication participated in the studies. Subjects' characteristics are summarized in table 5.1. The microinfusion system allows for local administration of up to two pharmacological agents simultaneously in the same subject. Most participants participated in three of the four experiments using different protocols. Subjects' characteristics and distribution of the sexes did not differ between experiments. The Oxfordshire Clinical Research Ethics Committee approved the studies and all subjects gave written informed consent before participating in the studies.

Table 5.1 Subjects' characteristics

\begin{tabular}{ll}
\hline Characteristic & \\
\hline Gender (m/f) & $4 / 5$ \\
Age (yr) & $30 \pm 3$ \\
Weight (kg) & $70.1 \pm 4.1$ \\
Height (m) & $1.72 \pm 0.04$ \\
BMI $\left(\mathrm{kg} / \mathrm{m}^{2}\right)$ & $23.4 \pm 0.7$ \\
Body fat (\%) & $22.7 \pm 2.2$ \\
Waist circumference (cm) & $79.0 \pm 2.1$ \\
Waist/hip ratio & $0.82 \pm 0.02$ \\
SBP (mmHg) & $112 \pm 4$ \\
DBP (mmHg) & $67 \pm 1$ \\
Fasting glucose (mmol/l) & $4.9 \pm 0.1$ \\
Fasting insulin (mU/l) & $9.5 \pm 0.5$ \\
\hline
\end{tabular}

Values are mcans \pm SEM. 
Subjects were asked to refrain from drinking alcohol and doing strenuous exercise for a period of $24 \mathrm{~h}$ before the study. Subjects came to the Clinical Research Unit by car or bus in the morning after an overnight fast and were studied at rest. On arrival, height, weight, waist and hip circumferences were measured. Body composition was determined using bioelectrical impedance (Bodystat-1500, Bodystat Ltd, Isle of Man, UK).

Small catheters were inserted into the abdominal subcutaneous adipose tissue (see 'Microinfusion protocol'). Resting blood pressure was recorded after 15 minutes rest and at intervals throughout the study. A 20-gauge cannula was inserted retrogradely into a superficial dorsal hand vein. This vein was heated in a hot box for at least 20 min to obtain arterialized venous blood. Arterialized blood samples were taken at different time points, depending on the type of experiment.

\section{Microinfusion protocol}

The microinfusion technique offers the unique possibility to monitor local ATBF using the ${ }^{133}$ xenon (133Xe) wash-out technique (22) and to manipulate local ATBF at the same time by local administration of a pharmacological agent (10). Right and left sides of the abdomen were studied simultaneously on each subject to allow direct comparison of the effects of the vasoactive compound on one site with the contralateral control site (saline infusion, $9 \mathrm{~g} / 1 \mathrm{NaCl}$ ). Importantly, the vasoactive compound was administered at the same level on the abdomen as the saline control site, as it has been previously shown that ATBF is greater at the upper level compared to the lower level of the abdomen $(23,24)$, but is not different between the right and the left sides at either level (23). To achieve this, small catheters (6 $\mathrm{mm}$ long, internal diameter $0.38 \mathrm{~mm}$, outer diameter $1.5 \mathrm{~mm}$, dead-space volume $60 \mu 1$ ) (Quick-set infusion set, MiniMed, Applied Medical Technology Ltd, Cambridge, UK) were inserted $6-8 \mathrm{~cm}$ on either side of the midline of the abdomen into the abdominal subcutaneous adipose tissue, and a saline infusion was started at $2 \mu \mathrm{l} / \mathrm{min}$ (CMA100 pumps, CMA microdialysis Ltd, Sunderland, UK). After $20 \mathrm{~min}$ recovery, ${ }^{133} \mathrm{Xe}$ (total dose of $2.0 \mathrm{MBq}$ per study) was injected at each site through the port in the hub of the catheter, and a $\gamma$-counter probe (Oakfield Instruments, Eynsham, UK) was placed over the infusion device. The half-life of ${ }^{133} \mathrm{Xe}$ (5.25 days) allows measurements of local ATBF throughout the entire study after a single injection of ${ }^{133} \mathrm{Xe}$. Subsequently, the catheter was perfused with saline for $1 \mathrm{~min}$ at $60 \mu \mathrm{l} / \mathrm{min}$ to wash the dead space, and for a 
further $40-60 \mathrm{~min}$ at $2 \mu \mathrm{l} / \mathrm{min}$ to allow for equilibration of ${ }^{133} \mathrm{Xe}$. Importantly, it can be estimated that tissue concentrations of the agents that are administered are approximately 1000 -fold lower than the concentrations in the infusate. Using the present methodology (infusing agents at an infusion rate of $2 \mu \mathrm{l} / \mathrm{min}$ in a presumed volume of $1 \mathrm{~cm}^{3}$ ), it would take several hours to achieve tissue concentrations that are comparable with the concentrations in the infusate. In addition, there is a rapid turnover of the fluid phase due to ATBF, which further dilutes the tissue concentrations.

\section{Ang II dose-response experiments}

The effect of angiotensin II (Ang II: $10^{-9}, 10^{-7}, 10^{-5} \mathrm{M}$ ) on ATBF was investigated in four subjects (figure 5.1A). At time zero, the saline was switched at either the left or the right side (chosen at random), by disconnection at the hub of the infusion set, to Ang II (h-Angiotensin II, Clinalfa, Switzerland), while the infusion rate was maintained at $2 \mu \mathrm{l} / \mathrm{min}$. Each dose of Ang II was administered for $45 \mathrm{~min}$ starting with the lowest dose. The ATBF recording over the next 135 minutes assessed the effect of Ang II, while the saline infusion was continued on the contralateral site to examine whether there were any changes in ATBF during the experiment that could not be attributed to Ang II action. After two baseline arterialized blood samples had been taken at time-point ( $t$, in minutes) -20 ( $t-20)$ and $\mathrm{t} 0$, further samples were taken at $\mathrm{t} 45, \mathrm{t} 90$, and $\mathrm{t} 135$. Ang II was dissolved in saline and diluted to the appropriate concentrations just before the start of the experiment.

\section{$A T$, receptor blockade and $A C E$ inbibition experiments}

The effects of the ACE inhibitor enalaprilate $\left(10^{-3} \mathrm{M}\right)$ and the specific $A T_{1}$ receptor antagonist losartan $\left(10^{-3} \mathrm{M}\right)$ were investigated in six subjects to examine the importance of locally produced and circulating Ang II in fasting and postprandial ATBF regulation (figure 5.1B). The reason for using a high dose of the ACE inhibitor was to block local Ang II generation. Similarly, a high dose of the $\mathrm{AT}_{1}$ receptor blocker was administered to block Ang II action.

At time zero, the saline was switched at either the left or the right side (chosen at random) to either the ACE inhibitor enalaprilate (Renitec, MSD, Haarlem, The Netherlands) or the $\mathrm{AT}_{1}$ receptor blocker losartan (Cozaar, MSD), while the infusion rate was maintained at $2 \mu \mathrm{l} / \mathrm{min}$. The ATBF recording over the next 

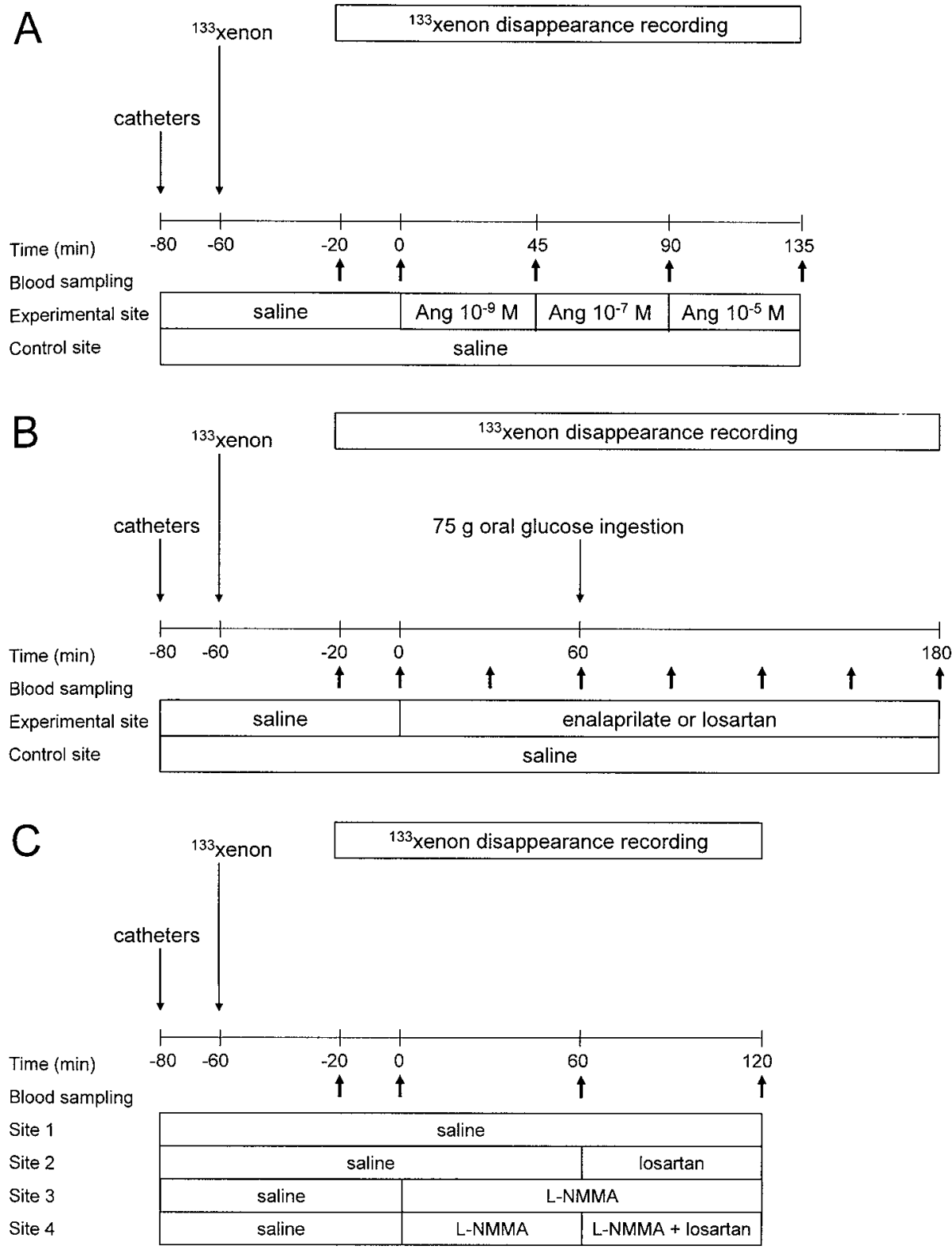

Figure 5.1 Time line diagrams of the different experiments. Ang II dose-response experiments were performed to assess the effect of local Ang II stimulation on $\mathrm{ATBF}^{4}(\Lambda)$. In addition, the functional $A T B F^{7}$ response to the $A C E$ inhibitor enalaprilate (inhibition of local Ang II production) and the $A T_{1}$ receptor blocker losartan (blockade of $\mathrm{Ang}$ II action) was investigated under fasting and postprandial (after $75 \mathrm{~g}$ oral glucose at $60 \mathrm{~min}$ ) conditions (B). To assess the contribution of NO action to the Ang II-induced effect on $A T B l^{2}$, the $A \mathrm{TBI}^{2}$ response to the NOS inhibitor I-NMM $A$ (inhibition of local NO production) in combination with $\lambda T_{1}$ receptor blockade was compared to the $A T B F$ response to NOS blockade alone (C). Thick arrows represent blood samples and blood pressure time points. 
60 min assessed the effects of $\mathrm{ACE}$ inhibition and $\mathrm{AT}_{1}$ receptor blockade, while the saline infusions were continued on the contralateral sites. At t60, $75 \mathrm{~g}$ glucose dissolved in $200 \mathrm{ml}$ of lemon-flavoured water was ingested to stimulate ATBF, and infusions were continued for a further $120 \mathrm{~min}$. After two baseline arterialized blood samples had been taken (at $\mathrm{t}-20$ and $\mathrm{t} 0$ ), additional samples were taken at 30 min intervals. Losartan was dissolved in saline, sterile-filtered and diluted to the appropriate concentration just before the start of the experiment. Enalaprilate was provided as a sterile solution by the manufacturer.

\section{Ang II - NO interaction experiments}

To assess the contribution of NO action to the Ang II-induced effect on ATBF, the effects of the NO synthase (NOS) inhibitor $N^{\mathrm{G}}$-monomethyl-L-arginine (LNMMA) alone $\left(10^{-3} \mathrm{M}\right)$ and in combination with the $\mathrm{AT}_{1}$ receptor blocker losartan $\left(10^{-3} \mathrm{M}\right)$ were investigated in five subjects (figure $5.1 \mathrm{C}$ ). At time zero, the saline was switched at either the left or the right side (chosen at random) to the NOS inhibitor L-NMMA, while the infusion rate was maintained at $2 \mu \mathrm{l} / \mathrm{min}$. The ATBF recording over the next $60 \mathrm{~min}$ assessed the effect of NOS blockade, while the saline infusions were continued on the contralateral sites. At $t 60$, one of the saline sites (chosen at random) was switched to the $A T_{1}$ receptor blocker and one of the NOS blockade sites was switched to the $\mathrm{AT}_{1}$ receptor blocker in combination with the NOS inhibitor, and infusions were continued for a further $60 \mathrm{~min}$ to assess the interaction between Ang II and NO in ATBF regulation. After two baseline arterialized blood samples had been taken (at $\mathrm{t}-20$ and $\mathrm{t} 0$ ), further samples were taken at $\mathrm{t} 60$ and $\mathrm{t} 120$. L-NMMA was dissolved in saline, sterile-filtered and diluted to the appropriate concentration just before the start of the experiment.

\section{Biocbemical measurements}

Arterialized blood samples were immediately placed on ice and were centrifuged $(1000 \mathrm{~g})$ at $4^{\circ} \mathrm{C}$ for 10 minutes, and plasma was stored at $-20^{\circ} \mathrm{C}$ until analysis. Plasma glucose (24) and non-esterified fatty acids (NEFA) concentrations (Wako NEFA C kit, Alpha Laboratories, Eastleigh, UK) were measured using an enzymatic method. Plasma insulin concentrations were determined by a doubleantibody radioimmunoassay (Pharmacia and Upjohn, Milton Keynes, UK). 


\section{Calculations}

${ }^{133} \mathrm{Xe}$ counts were recorded continuously as $20 \mathrm{~s}$ readings, and blood flow was calculated as the mean of consecutive $10 \mathrm{~min}$ time periods, as previously described $(10,14)$. The partition coefficient for ${ }^{1.33} \mathrm{Xe}$ between adipose tissue and blood was assumed to have a value of $10 \mathrm{ml} / \mathrm{g}$ for all subjects (25).

The effect of Ang II was analyzed by averaging the two consecutive time points at the end of each $45 \mathrm{~min}$ infusion period ( $t 35$ and $t 45, t 80$ and $t 90$, and $t 125$ and t135), when a steady-state in ATBF was reached, after subtraction of baseline blood flow ( $t-20$ to $t 0$ ). It is important to recognize that we cannot be certain of the volume of distribution of the agents infused with respect to the depot of ${ }^{133 \mathrm{Xe}}$ and the exact tissue concentrations, because microinfusion of pharmacological agents creates drug concentration gradients in the tissue volume from which ${ }^{133 \mathrm{Xe}}$ clearance is recorded. This experimental problem implies that the estimates of the size of the effects of the pharmacological agents that are infused on ATBF should be regarded as qualitative or semi-quantitative. For the $A T_{1}$ receptor blockade and ACE inhibition experiments, the stability of ATBF during the baseline period ( $t-20$ to $t 0$ ) and the 30 min period before glucose ingestion (pre-glucose period, $t 30$ to t60) at the control (saline) sites was tested using Students's paired $t$-test. Responses to pharmacological agents were evaluated within individuals by comparison with the saline control site at the same level on the abdomen. Relative changes in ATBF at the experimental site are presented as changes from baseline values after correction for corresponding changes in ATBF at the control site. The effects of local $\mathrm{AT}_{1}$ receptor blockade and $\mathrm{ACE}$ inhibition were analyzed by averaging the three consecutive time points before glucose intake ( $t 40$, t50 and $t 60)$ after subtraction of baseline blood flow ( $t-20$ to t0). Peak ATBF values were calculated as the mean of three consecutive time points, including the maximum ATBF, which resulted in the highest mean value within each subject (10). The effect of glucose intake on ATBF was analysed using the area under the curve (AUC) by the trapezoidal rule. AUCs were divided by the time over which they were calculated (120 min). To assess the contribution of NO action to the Ang II-induced effect on ATBF, the effect of combined $A T_{1}$ receptor and NOS blockade was compared with that of $A T_{1}$ receptor blockade alone by averaging the three consecutive time points at the end of each 60 min infusion period (t40, t50 and $t 60$, and $t 100, t 110$ and $\mathrm{t} 120$ ). The reproducibility of the blood flow recordings was assessed by calculating coefficients of variation (CVs). 


\section{Statistics}

Data are presented as mean \pm standard error of the mean (SEM). Overall effects of treatment compared with control were analysed using repeated-measures ANOVA to identify time effects, drug effects, and time and drug interactions. Changes in glucose, insulin and NEFA concentrations with time were assessed by repeatedmeasures ANOVA, using time and treatment as within-subject factors. Post hoc comparisons of drug effects and changes in biochemical data within subjects were done using Student's paired $t$-tests. Calculations were done using SPSS 10.1 for Windows (Chicago, IL, USA). $P<0.05$ was considered to be statistically significant.

\section{Results}

\section{Systemic responses}

Fasting plasma glucose $(4.9 \pm 0.1 \mathrm{mmol} / \mathrm{l})$, insulin $(9.5 \pm 0.5 \mathrm{mU} / \mathrm{l})$, and NEFA $(551 \pm 72 \mu \mathrm{mol} / \mathrm{l})$ concentrations were stable during the baseline period and the 30 min period before glucose ingestion (pre-glucose period) in the $A T_{1}$ receptor blockade and ACE inhibition experiments and during the course of the Ang II dose-response and Ang II - NO interaction experiments. After ingestion of glucose in the $\mathrm{AT}_{1}$ receptor blockade and $\mathrm{ACE}$ inhibition experiments, plasma glucose and insulin concentrations were significantly increased, whereas plasma NEFA concentrations were significantly decreased. Concentrations and responses corresponded to those expected in healthy lean subjects and were comparable between the different experiments. Mean blood pressure was unchanged during the course of the experiments (data not shown).

\section{Reproducibility of blood flow recordings}

Baseline blood flow recordings were stable; there were no significant differences in ATBF between $\mathrm{t}-20$ and $\mathrm{t} 0$ in the different experiments: mean values were $5.0 \pm 0.4$ and $5.1 \pm 0.4 \mathrm{ml} \cdot 100 \mathrm{~g}$ tissue ${ }^{-1} \cdot \mathrm{min}^{-1}$, respectively $(\mathrm{CV}, 5.8 \pm 0.8 \%)$. Baseline ATBF was significantly correlated between right and left sides (Pearson's $r=0.89, P<0.001$ and Pearson's $r=0.92, P<0.001$ for superior and inferior sides, respectively). The CVs calculated from the paired data from left and right sides were $18.8 \pm 1.9 \%$ and $15.9 \pm 4.7 \%$ for superior and inferior sides, respectively. 


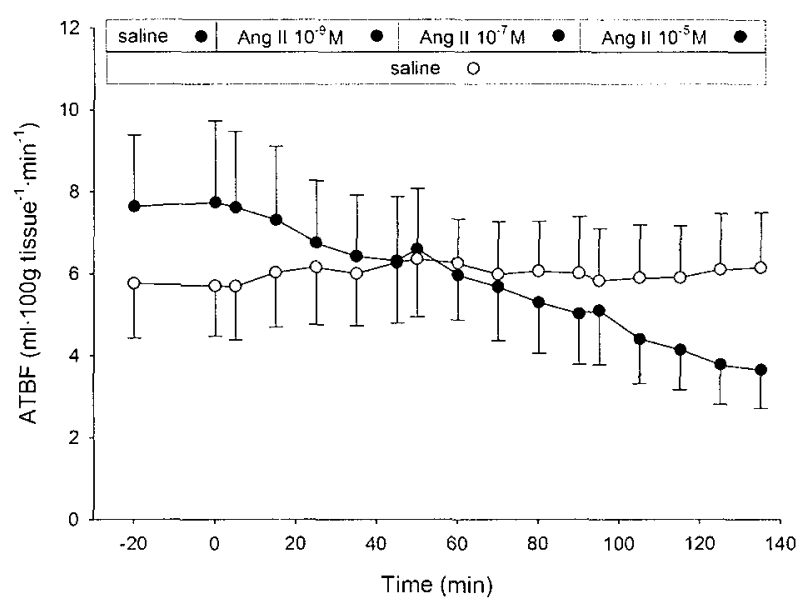

Figure $5.2 \mathrm{ATBF}$ in response to local stimulation with Ang II at three concentrations: $10^{9} \mathrm{M}$, $10^{7} \mathrm{M}$, and $10^{-5} \mathrm{M}$ (closed circles) ( $n=4$ ). Open circles represent microinfusion of saline (control). Valucs are means \pm SEM.

\section{Effect of Ang II on ATBF}

Ang II stimulation induced a dose-dependent decrease in ATBF $\left(10^{-9} \mathrm{M}:-16 \%\right.$, $P=0.04 ; 10^{-7} \mathrm{M}:-33 \%, P<0.01 ; 10^{-5} \mathrm{M}:-53 \%, P<0.01$ vs. baseline) (figure 5.2 ). The reduction in ATBF during Ang II stimulation was significantly different between the different Ang II concentrations that were administered $\left(10^{-9} \mathrm{M}\right.$ vs. $10^{-7} \mathrm{M}$, $P=0.03 ; 10^{-7} \mathrm{M}$ vs. $\left.10^{-5} \mathrm{M}, P<0.01\right)$. As expected, saline infusion on the contralateral site had no effect on ATBF, indicating that the effect of local Ang II stimulation on ATBF cannot be attributed to systemic changes.

\section{Effects of $A T$, receptor bluck ade and $A C E$ inbibition on $A T B F$}

At the saline infusion (control) sites, ATBF was stable during the baseline period and the $30 \mathrm{~min}$ period before glucose ingestion (pre-glucose period) in the ACE inhibition experiment (baseline: $5.0 \pm 1.1$; pre-glucose: $4.9 \pm 1.1 \mathrm{ml} \cdot 100 \mathrm{~g}$ tissue ${ }^{-1} \cdot \mathrm{min}^{-1}$, NS) and the $\mathrm{AT}_{1}$ receptor blockade experiment (baseline: 4.1 \pm 1.2 ; pre-glucose: $4.1 \pm 1.2 \mathrm{ml} \cdot 100 \mathrm{~g}$ tissue ${ }^{-1} \cdot \mathrm{min}^{-1}$, NS) (table 5.2). There were no significant differences in baseline $\mathrm{ATBF}$ between contralateral saline and treatment sites (all saline during baseline period). In response to glucose ingestion, the ATBF increase on the control (saline infusion) site was comparable in the ACE inhibition (42\%, 
Table 5.2 Baseline, pre-glucose and postprandial $\mathrm{ATBF}$ in response to $\mathrm{ACE}$ inhibition (enalaprilate) and $A \mathrm{~T}_{1}$ reccptor blockade (losartan)

\begin{tabular}{llll}
\hline & Baseline & Pre-glucose & Postprandial \\
\hline$A C E$ inhibition & $4.6 \pm 0.9$ & $5.3 \pm 1.1$ & $7.1 \pm 1.1^{*}$ \\
Control & $5.0 \pm 1.1$ & $4.9 \pm 1.1$ & $7.0 \pm 1.5^{*}$ \\
$\mathrm{AT}_{1}$ receptor blockade & $3.6 \pm 1.1$ & $5.5 \pm 1.2 \mathrm{H}$ & $6.3 \pm 1.2 \dagger$ \\
Control & $4.1 \pm 1.2$ & $4.1 \pm 1.2$ & $6.2 \pm 1.5 \dagger$ \\
\hline
\end{tabular}

Control indicates infusion of saline on the contralateral site in the same individual. The effect of $A C E$ inhibition and $\mathrm{AT}_{1}$ receptor blockade on fasting $\mathrm{ATBF}$ was examined by comparison of $\mathrm{ATBF}$ during the pre-glucose period with baseline ATBF. The effect of treatments on postprandial ATBF (ingestion of an oral glucose load) was assessed by comparison with baseline $\lambda \mathrm{TBF}$. $* P<0.05 \mathrm{us}$. baseline, $t P<0.01 \mathrm{k}$. baseline, $\neq P<0.01$ is. control. Values are means $\pm \mathrm{SEM}$, in $\mathrm{ml} \cdot 100 \mathrm{~g} \mathrm{tissue}^{-1} \cdot \mathrm{min}^{-1}$.

$P<0.01)$ and $A T_{1}$ receptor blockade $(50 \%, P<0.01)$ experiments (figures 5.3 and 5.4, and table 5.2).

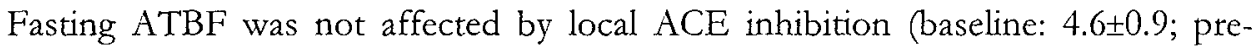
glucose: $5.3 \pm 1.1 \mathrm{ml} \cdot 100 \mathrm{~g}$ tissue ${ }^{-1} \cdot \mathrm{min}^{-1}, N S$ ) (figure 5.3 and table 5.2 ), but was

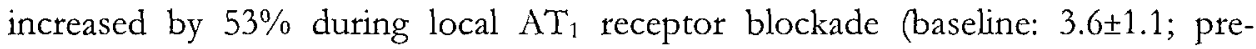
glucose: $5.5 \pm 1.2 \mathrm{ml} \cdot 100 \mathrm{~g}$ tissue ${ }^{-1} \cdot \mathrm{min}^{-1}, P<0.01$ ) (figure 5.4 and table 5.2 ).

Local ACE inhibition and $\mathrm{AT}_{1}$ receptor blockade did not affect the postprandial enhancement of ATBF. The ATBF increase after glucose ingestion during ACE inhibition (baseline: $4.6 \pm 0.9$; postprandial: $7.1 \pm 1.1 \mathrm{ml} \cdot 100 \mathrm{~g}$ tissue $\mathrm{e}^{-1} \cdot \mathrm{min}^{-1}, P=0.02$ ) was not significantly different compared to the ATBF increase at the saline control site (baseline: $5.0 \pm 1.1$; postprandial: $7.0 \pm 1.5 \mathrm{ml} \cdot 100 \mathrm{~g}$ tissue $\mathrm{e}^{-1} \cdot \mathrm{min}^{-1}, P=0.02$ ). Likewise, the ATBF increase after the oral glucose load during $A T_{1}$ receptor blockade (baseline: $3.6 \pm 1.1$; postprandial: $6.3 \pm 1.2 \mathrm{ml} \cdot 100 \mathrm{~g}$ tissue ${ }^{-1} \cdot \mathrm{min}^{-1}, P<0.01$ ) was comparable with the ATBF increase at the saline control site (baseline: $4.1 \pm 1.2$; postprandial: $6.2 \pm 1.5 \mathrm{ml} \cdot 100 \mathrm{~g}$ tissue $\left.{ }^{-1} \cdot \mathrm{min}^{-1}, P<0.01\right)$. This is further illustrated by comparable ATBF AUCs during local ACE inhibition (ACE inhibition: 5.8 \pm 0.9 ; control: $5.8 \pm 0.2 \mathrm{ml} \cdot 100 \mathrm{~g}$ tissue- $\left.\cdot \mathrm{min}^{-1}, \mathrm{NS}\right)$ and $A \mathrm{~T}_{1}$ receptor blockade $\left(A \mathrm{~T}_{1}\right.$ receptor blockade: $5.3 \pm 1.1$; control: $4.9 \pm 1.3 \mathrm{ml} \cdot 100 \mathrm{~g}$ tissue ${ }^{-1} \cdot \mathrm{min}^{-1}, \mathrm{NS}$ ) compared to control.

\section{Interaction between Ang II and NO in ATBF regulation}

No significant differences in baseline ATBF were observed between control and treatment sites (all saline during baseline period). NOS blockade by L-NMMA induced a $\sim 30 \%$ decrease in fasting ATBF at both NOS blockade sites (t0 to t60) (both $P=0.001$ ) (figure 5.5). At $t 60$, one of the saline sites was switched to the $A T_{1}$ 


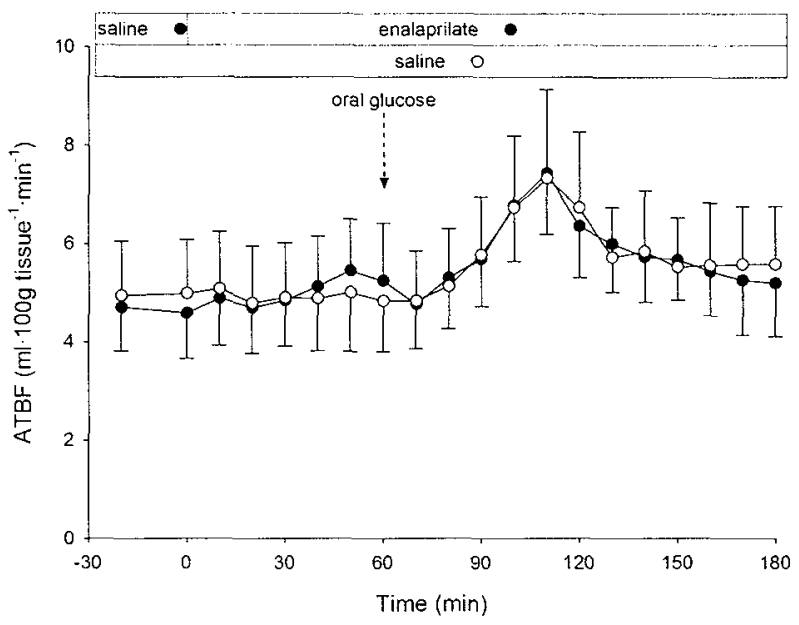

Figure 5.3 $\mathrm{ATBF}$ in response to local $\mathrm{ACE}$ inhibition. Closed circles represent pharmacological inhibition of Ang II production by the ACE inhibitor enalaprilate $\left(10^{-3} \mathrm{M}\right)(n=6)$. Open circles represent contralateral saline control. Oral glucose is given at t60 min to stimulate ATBF. Values are means \pm SEM.

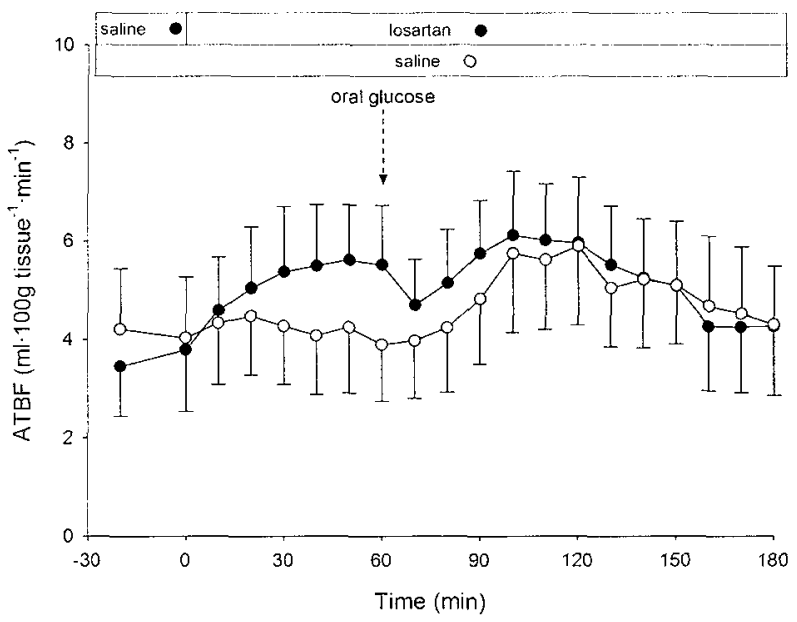

Figure $5.4 \mathrm{ATBF}$ in response to local $\lambda \mathrm{T}_{1}$ receptor blockade. Closed circles represent pharmacological blockade of the $A \mathrm{~T}_{\text {: }}$ receptor by losartan $\left(10^{3} \mathrm{M}\right)(n=6)$. Open circles represent contralateral saline control. Oral glucose is given at t60 min to stimulate. ITBR. Values are means \pm SEM. 


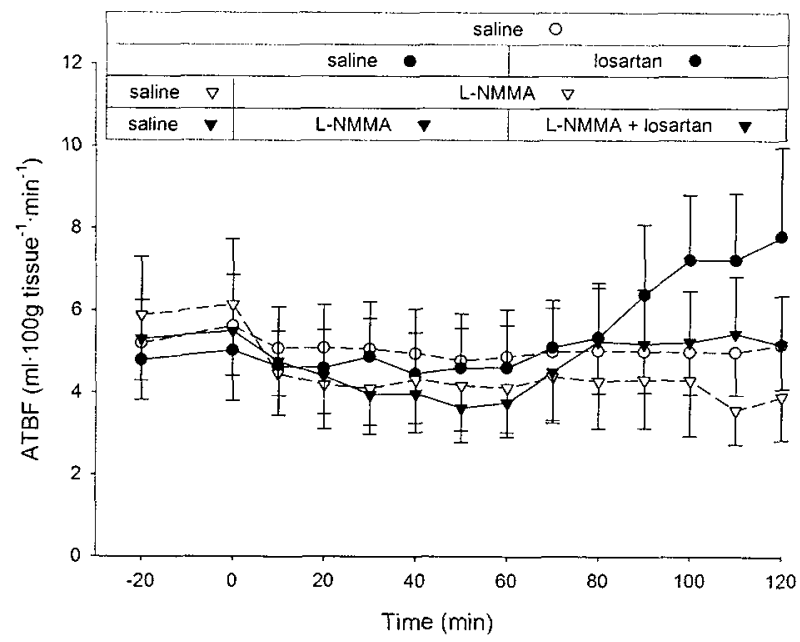

Figure $5.5 \mathrm{ATBF}$ in response to local $\mathrm{AT}$, receptor blockade by losartan $\left(10^{-3} \mathrm{M}\right)$ (closed circles), contralateral saline control for $A T_{i}$ receptor blockade (open circles), local NOS blockade by 1 NMMA $\left(10^{-3} \mathrm{M}\right)$ alone and in combination with $\mathrm{AT}_{1}$ receptor blockade $\left(10^{-3} \mathrm{M}\right)$ (closed triangles), and local NOS blockade $\left(10^{-3} \mathrm{M}\right.$ ) (control for $A T_{1}$ receptor blockade in combination with NOS blockade) (open triangles) $(n=5)$. Values are means \pm SEM.

receptor blocker losartan and one of the NOS blockade sites was switched to the NOS blocker L-NMMA in combination with the $A T_{1}$ receptor blocker. Local $A T_{1}$ receptor blockade increased fasting ATBF compared to contralateral saline infusion ( $60 \%$ vs. $6 \%, P=0.001$, respectively), whereas combined $A_{1}$ receptor and NOS blockade elevated fasting ATBF compared to NOS blockade alone $(39 \%$ us. $-7 \%, P=0.003$, respectively). $A T_{1}$ receptor blockade induced a more pronounced increase in ATBF compared to combined $\mathrm{AT}_{1}$ receptor and NOS blockade $60 \%$ vs. $39 \%, P=0.02$, respectively). However, after correction for corresponding changes in ATBF at the control sites, the net increase in ATBF during local AT receptor blockade (control: saline site) was not significantly different from the net increase in $\mathrm{ATBF}$ during combined $\mathrm{AT}_{1}$ receptor and NOS blockade (control: NOS blockade site) (54\% vs. $46 \%, N S$, respectively).

\section{Discussion}

We demonstrated that, using the recently developed microinfusion technique, Ang II acts as a potent vasoconstrictor in adipose tissue under fasting conditions, as shown by the marked decrease in ATBF when Ang II was infused locally. Local 
ACE inhibition (inhibition of local Ang II generation) showed that locally produced Ang II in adipose tissue does not appear to regulate ATBF, as no significant change in $A T B F$ was observed. In contrast, $A T_{1}$ receptor blockade (blockade of Ang II action) induced a marked increase in ATBF, indicating that circulating Ang II that reaches adipose tissue is a major regulator of fasting ATBF. Ang II does not appear to have great impact on the postprandial enhancement of ATBF. Finally, the Ang II - NO interaction experiments demonstrated that a major proportion of the Ang II-induced decrease of ATBF is NO independent. Biochemical parameters and blood pressure were unchanged during the course of the different experiments, which clearly indicates that there were no systemic effects of the pharmacological agents that were locally infused in adipose tissue. The Ang II dose-response data show that local administration of Ang II to abdominal subcutaneous adipose tissue induced a dose-dependent decrease in fasting ATBF, which was sustained throughout the course of the experiment. In line with the well-known vasoconstrictive effect of Ang II in other tissues, this finding was not unexpected. The magnitude of the observed effect indicates that Ang II could be a major regulator of fasting ATBF in humans. These observations are in agreement with our previous findings, where we showed that Ang II reduced adipose tissue and skeletal muscle blood flow under fasting conditions using the microdialysis technique (20).

There is evidence that Ang II may be produced locally in adipose tissue (15-19) and could play a role in obesity-related hypertension and insulin resistance (26). It is not easy to investigate the actions of Ang II in individual tissues, but an elegant approach to examining such a question has recently been made using a crosstransplantation strategy and $A T_{1 A}$ receptor-deficient mice. The equal contribution of Ang II actions in the kidney and in extra-renal tissues with regard to blood pressure regulation by the renin-angiotensin system (RAS) was demonstrated (27). In addition, it is extremely difficult to disentangle the physiological relevance of locally produced and circulating Ang II in an individual tissue. With the model used in the present study, we are to our knowledge the first to determine the relative contributions of locally produced Ang II in adipose tissue and circulating Ang II that reaches adipose tissue to an Ang II-induced effect in this tissue, in this case the Ang II-induced effect on ATBF. To achieve this, we exposed the adipose tissue to selective $A T_{1}$ receptor blockade and $A C E$ inhibition. For reasons related to the methodology used, it was impossible to demonstrate that local Ang II production was indeed decreased after local ACE inhibition. However, it seems highly likely that substantial inhibition of local Ang II production was 
accomplished by local ACE inhibition, as $>95 \%$ blockade of Ang I-to-Ang II conversion has been demonstrated in the human forearm using the same ACE inhibitor and even a lower dose than was used in the present study (28). Similarly, a high dose of the $\mathrm{AT}_{1}$ receptor blocker was administered to substantially block Ang II action. We demonstrated that local $A T_{1}$ receptor blockade markedly increased fasting $\mathrm{ATBF}$, whereas fasting ATBF was not significantly increased during local ACE inhibition, suggesting that fasting ATBF is predominantly controlled by circulating Ang II concentrations, whereas locally produced Ang II does not appear to regulate ATBF. Because Ang II is produced by the adipocyte, the present data suggest that locally produced Ang II in adipose tissue acts as a paracrine hormone that does not reach the endothelium to induce vasoconstriction.

We cannot fully exclude the possibility that locally generated Ang II plays a minor role in ATBF regulation, because ACE-independent pathways of Ang II generation have been demonstrated in several tissues (29-31), and human studies indicate that such pathways could substantially contribute to total Ang II formation (32). However, there is no evidence that non-ACE pathways play a role in Ang II formation in vivo in human adipose tissue. Secondly, ACE inhibition reduces the breakdown of bradykinin $(33,34)$, and in vitro findings and animal studies suggest that this may lead to a vasodilatory response via the cGMP/NO pathway (35-37). Based on the present findings, however, involvement of $\mathrm{ACE}$ inhibitor-induced stimulation of the bradykinin/cGMP/NO pathway in ATBF regulation seems unlikely.

There were several reasons why we wanted to address the question as to whether the Ang II-induced decrease in ATBF is dependent on interaction with NO. First, it has been demonstrated that NOS inhibition decreased fasting ATBF (14), suggesting that the balance between Ang II and NO stimulation may be an important determinant of the vascular tone and thus ATBF under fasting conditions. Secondly, it can be argued that the increase in ATBF during $A T_{1}$ receptor blockade may be enhanced by increased production of NO. In this case, $\mathrm{AT}_{1}$ receptor blockade may increase Ang II action through the Ang II type 2 ( $\left.\mathrm{AT}_{2}\right)$ receptor, and it has been suggested that this receptor may play a counterregulatory role mediated via bradykinin and NOS against the pressor actions of Ang II (3537). Furthermore, Ang II increased through its $A T_{1}$ receptor the activity of the superoxide-producing enzyme NADPH oxidase and thereby inactivated NO, leading to impaired endothelium-dependent vasodilatation (21). In line with this, there is evidence for increased NO bioavailability and decreased oxidative stress after $A T_{1}$ receptor blockade (21). Therefore, both stimulation of the $\mathrm{AT}_{2}$ receptor, 
resulting in stimulation of the bradykinin/cGMP/NO pathway, and increased NO action due to inhibition of NADPH oxidase activity could be relevant in (pathophysiological) situations where $A T_{1}$ receptor blockers are used. Our Ang II$\mathrm{NO}$ interaction experiments clearly show that the major proportion of the increase in $A T B F$ during $A T_{1}$ receptor blockade is NO independent or, in other words, that the Ang II-induced decrease in ATBF is predominantly independent of NO action. The postprandial enhancement of ATBF was not affected by either ACE inhibition or $A T_{1}$ receptor blockade, suggesting that $A$ ng II has no major effect on the regulation of ATBF after a meal. This is in accordance with previous investigations showing that postprandial ATBF is principally controlled by the $\beta$ adrenergic system $(14,38)$. The ATBF response induced by a meal may have metabolic consequences. It has been shown that the extraction of plasma triacylglycerol is elevated with increasing ATBF (5), and this may also be the case for glucose extraction. The present data show that Ang II is involved in fasting, but not postprandial ATBF regulation. However, because Ang II decreases the absolute level of fasting ATBF, this may result in a reduced absolute ATBF after a meal in conditions where RAS activity is increased. This could have pathophysiological implications in that postprandial hyperlipidemia and hyperglycemia may occur, which are well-known cardiovascular risk factors.

In conclusion, the present findings demonstrate that circulating Ang II is a major regulator of fasting $\mathrm{ATBF}$, and that a major proportion of the Ang II-induced decrease of ATBF is NO independent. Locally produced Ang II does not appear to regulate ATBF. Furthermore, Ang II appears to have no major effect on the postprandial enhancement of ATBF.

\section{Acknowledgements}

G. Goossens was supported by a grant from the Netherlands Organisation for Scientific Research (NWO). S. McQuaid is a Wellcome Trust Clinical Training Fellow. F. Karpe is a Wellcome Trust Senior Clinical Research Fellow. The research was supported by the Wellcome Trust. 


\section{References}

1. Bulow J, Astrup A, Christensen NJ, Kastrup J. Blood flow in skin, subcutaneous adipose tissue and skeletal muscle in the forearm of normal man during an oral glucose load. Acta Physiol Scand 1987;130(4):657-61.

2. Coppack SW, Evans RD, Fisher RM, Frayn KN, Gibbons GF, Humphreys SM, et al. Adipose tissue metabolism in obesity: lipase action in vivo before and after a mixed meal. Metabolism 1992;41(3):264-72.

3. Evans K, Clark ML, Frayn KN. Effects of an oral and intravenous fat load on adipose tissue and forearm lipid metabolism. Am J Physiol 1999;276(2 Pt 1):E241-8.

4. Frayn KN, Karpe F, Fielding BA, Macdonald IA, Coppack SW. Integrative physiology of human adipose tissue. Int J Obes Relat Metab Disord 2003;27(8):875-88.

5. Samra JS, Simpson E], Clark ML, Forster CD, Humphreys SM, Macdonald IA, et al. Effects of epinephrine infusion on adipose tissue: interactions between blood flow and lipid metabolism. Am J Physiol 1996;271(5 Pt 1):E834-9.

6. Jansson PA, Larsson A, Lonnroth PN. Relationship between blood pressure, metabolic variables and blood flow in obese subjects with or without non-insulin-dependent diabetes mellitus. Eur J Clin Invest 1998;28(10):813-8.

7. Summers LK, Samra JS, Humphreys SM, Morris RJ, Frayn KN. Subcutaneous abdominal adipose tissue blood flow: variation within and between subjects and relationship to obesity. Clin Sci (Lond) 1996;91(6):679-83.

8. Blaak EE, van Baak MA, Kemerink GJ, Pakbiers MT, Heidendal GA, Saris WH. Betaadrenergic stimulation and abdominal subcutaneous fat blood flow in lean, obese, and reducedobese subjects. Metabolism 1995;44(2):183-7.

9. Karpe F, Fielding BA, Ilic V, Macdonald IA, Summers LK, Frayn KN. Impaired postprandial adipose tissue blood flow response is related to aspects of insulin sensitivity. Diabetes 2002;51(8):2467-73.

10. Karpe F, Fielding BA, Ardilouze JL, Ilic V, Macdonald IA, Frayn KN. Effects of insulin on adipose tissue blood flow in man. J Physiol 2002;540(Pt 3):1087-93.

11. Schiffelers SL, Akkermans JA, Saris WH, Blaak EE. Lipolytic and nutritive blood flow response to beta-adrenoceptor stimulation in situ in subcutaneous abdominal adipose tissue in obese men. Int J Obes Relat Metab Disord 2003;27(2):227-31.

12. Samra JS, Simpson EJ, Clark ML, Forster CD, Humphreys SM, Macdonald I $i$, et al. Effects of adrenaline infusion on the interstitial environment of subcutaneous adipose tissue as studied by microdialysis. Clin Sci (Lond) 1996;91(4):425-30.

13. Millet L, Barbe P, Lafontan M, Berlan M, Galitzky J. Catecholamine effects on lipolysis and blood flow in human abdominal and femoral adipose tissue. J Appl Physiol 1998;85(1):181-8.

14. Ardilouze JL, Fielding BA, Currie JM, Frayn KN, Karpe F. Nitric oxide and beta-adrenergic stimulation are major regulators of preprandial and postprandial subcutaneous adipose tissue blood flow in humans. Circulation 2004;109(1):47-52.

15. Harte A, McTernan P, Chetty R, Coppack S, Katz J, Smith S, et al. Insulin-mediated upregulation of the renin angiotensin system in human subcutaneous adipocytes is reduced by rosiglitazone. Circulation 2005;111(15):1954-61.

16. Danser AH. Local renin-angiotensin systems. Mol Cell Biochem 1996;157(1-2):211-6.

17. Phillips MI, Speakman EA, Kimura B. Levels of angiotensin and molecular biology of the tissue renin angiotensin systems. Regul Pept 1993;43(1-2):1-20.

18. Unger $T$, Gohlke $P$. Tissue renin-angiotensin systems in the heart and vasculature: possible involvement in the cardiovascular actions of converting enzyme inhibitors. Am J Cardiol 1990;65(19):3I-10I.

19. Dzau VJ. Circulating versus local renin-angiotensin system in cardiovascular homeostasis. Circulation 1988;77(6 Pt 2):I4-13. 
20. Goossens GH, Blaak EE, Saris WH, Van Baak MA. Angiotensin Il-induced effects on adipose and skeletal muscle tissue blood flow and lipolysis in normal-weight and obese subjects. J Clin Endocrinol Metab 2004;89(6):2690-6.

21. de Gasparo M. Angiotensin II and nitric oxide interaction. Heart Fail Rev 2002;7(4):347-58.

22. Samra JS, Frayn KN, Giddings J $A$, Clark ML, Macdonald IA. Modification and validation of a commercially available portable detector for measurement of adipose tissue blood flow. Clin Physiol 1995;15(3):241-8.

23. Ardilouze JL, Karpe F', Currie JM, Frayn KN, Fielding BA. Subcutancous adipose tissue blood flow varies between superior and inferior levels of the anterior abdominal wall. Int $J$ Obes Relat Metab Disord 2004;28(2):228-33.

24. Simonsen L, Enevoldsen LH, Bulow J. Determination of adipose tissue blood flow with local 1.3.Xe clearance. Evaluation of a new labelling technique. Clin Physiol Funct Imaging 2003;23(6):320-3.

25. Yeh SY, Peterson RE. Solubility of krypton and xenon in blood, protein solutions, and tissue homogenates. J Appl Physiol 1965;20(5):1041-7.

26. Goossens GH, Blaak EE, van Baak MA. Possible involvement of the adipose tissue reninangiotensin system in the pathophysiology of obesity and obesity-related disorders. Obes Rev $2003 ; 4(1): 43-55$.

27. Crowley SD, Gurley SB, Oliverio MI, Pazmino AK, Griffiths R, lilannery PJ, et al. Distinct roles for the kidney and systemic tissues in blood pressure regulation by the renin-angiotensin system. J Clin Invest 2005;115(4):1092-9.

28. Saris JJ, van Dijk MA, Kroon I, Schalekamp MA, Danser AH. Functional importance of angiotensin-converting enzyme-dependent in situ angiotensin II generation in the human forearm. Hypertension 2000;35(3):764-8.

29. Hollenberg NK, Fisher ND, Price DA. Pathways for angiotensin II generation in intact human tissue: evidence from comparative pharmacological interruption of the renin system. Hypertension 1998;32(3):387-92.

30. Wolny $A$, Clozel JP, Rein J, Mory P, Vogt P, Turino M, et al. Functional and biochemical analysis of angiotensin II-forming pathways in the human heart. Circ Res 1997;80(2):219-27.

31. Urata $H$, Nishimura $H$, Ganten $D$. Chymase-dependent angiotensin II forming systems in humans. Am J Hypertens 1996;9(3):277-84.

32. Hollenberg NK. AT(1)-receptor blockade and the kidney: importance of non-ACE pathways in health and disease. J Hum Hypertens 2002;16 Suppl 3:S59-63.

33. Wacber B, Brunner HR. Cardiovascular hypertrophy: role of angiotensin II and bradykinin. ] Cardiovasc Pharmacol 1996;27(Suppl 2):S36-40.

34. Linz W, Wiemer G, Gohlke P, Unger $T$, Scholkens $B A$. Contribution of kinins to the cardiovascular actions of angiotensin- converting enzyme inhibitors. Pharmacol Rev 1995:47(1):25-49.

35. Tsutsumi Y, Matsubara H, Masaki H, Kurihara H, Murasawa S, Takai S, et al. Angiotensin II type 2 receptor overexpression activates the vascular kinin system and causes vasodilation. J Clin Invest 1999;104(7):925-35.

36. Siragy HM, Carey RM. Protective role of the angiotensin $A T_{2}$ receptor in a renal wrap hypertension model. Hypertension 1999;33(5):1237-42.

37. Gohlke $P, P e e s ~ C$, Unger $T$. $\mathrm{AT}_{2}$ receptor stimulation increases aortic cyclic GMP in SHRSP by a kinin-dependent mechanism. Hypertension 1998;31 (1 Pt 2):349-55.

38. Simonsen L, Bulow J, Astrup A, Madsen J, Christensen N]. Dict-induced changes in subcutaneous adipose tissue blood flow in man: effect of beta-adrenoceptor inhibition. Acta Physiol Scand 1990;139(2):341-6. 


\section{6}

Angiotensin II: a hormone that affects lipid metabolism in adipose tissue

Gijs H. Goossens ${ }^{1}$, Ellen E. Blaak ${ }^{1}$, Peter Arner², Wim H.M. Saris ${ }^{1}$ and Marleen A. van Baak ${ }^{1}$

${ }^{1}$ Department of Human Biology, Nutrition and Toxicology Research Institute Maastricht (NUTRIM), Maastricht University, Maastricht, The Netherlands

${ }^{2}$ Department of Medicine, Huddinge University Hospital, Karolinska Institute, Stockholm, Sweden

Int J Obes Relat Metab Disord 2006 (in press) 


\section{Abstract}

Alterations in adipose tissue lipolysis may contribute to the pathophysiology of obesity and insulin resistance. This study was designed to investigate the effects of angiotensin II (Ang II), the effector molecule of the renin-angiotensin system (RAS), on abdominal subcutaneous adipocyte lipolysis in normal-weight and obese subjects.

Two studies were performed. First, abdominal subcutaneous adipose tissue biopsies were obtained from nine normal-weight and seven obese male subjects after an overnight fast. Adipocytes were stimulated with Ang II (10-14-10-6 $\mathrm{M})$ to examine the effect of Ang II on fat cell lipolysis. In a second study, adipocytes of seven additional obese male subjects were stimulated with lower doses of Ang II $\left(10^{-17}-10^{-6} \mathrm{M}\right)$ in the presence and absence of $A T_{1}$ receptor blockade $\left(10^{-4} \mathrm{M}\right)$. Glycerol concentration in the medium was used as an indicator of fat cell lipolysis. Study 1 demonstrated that glycerol concentration in the medium was significantly reduced $(\sim 20 \%)$ during stimulation with Ang II in normal-weight $(P=0.04)$ and obese subjects $(P<0.001)$. The antilipolytic effect of Ang II was not significantly different between groups $(P=0.40)$. In Study 2 , glycerol release was significantly $(\sim 20-25 \%)$ and dose-dependently reduced during stimulation with Ang II $(P=0.001) . A_{1}$ receptor blockade completely abolished the Ang II-induced antilipolytic effects $(P=0.35)$.

The present data show for the first time that Ang II directly inhibits abdominal subcutaneous adipocyte lipolysis in normal-weight and obese subjects, and demonstrate that these effects are mediated through the $A T_{1}$ receptor. 


\section{Introduction}

It is well-established that upper body obesity is associated with insulin resistance and an increased risk of developing cardiovascular disease. Part of this association may be explained by the production of signalling molecules that are released from adipose tissue into the circulation and which influence metabolism and insulin sensitivity (1-3). However, autocrine and paracrine factors in adipose tissue that affect the buffering capacity for excess lipid storage may also underlic changes in insulin sensitivity. It has been proposed that an impaired adipocyte differentiation may play a role in the development of type 2 diabetes mellitus (4). In line with this, the thiazolidinediones, well-known insulin sensitizers, stimulate adipocyte differentiation in rats (5). The generation of sufficient adipocytes may increase the capacity for lipid storage, thereby preventing the deposition of lipids in other tissues such as skeletal muscle, which is associated with insulin resistance (6).

The presence of several components of the renin-angiotensin system (RAS) and angiotensin II (Ang II) receptors in human adipose tissue has been demonstrated (7-9), implying that the active component of the RAS, Ang II, can be produced locally in adipose tissue. There is substantial evidence that the adipose tissue RAS may be involved in obesity-related disorders, such as insulin resistance $(10,11)$, possibly through an effect on the buffering capacity for lipid storage in adipose tissue (12). It has been shown that Ang II inhibits differentiation of human preadipocytes (13), suggesting that there may be a paracrine negative feedback loop, where Ang II is secreted by mature adipocytes and inhibits further recruitement of preadipocytes (13). Furthermore, Ang II has been shown to exert direct lipogenic effects in 3T3-L1 preadipocytes and human adipocytes (14), and angiotensinogen (AGT), the precursor of Ang II, has been shown to play a role in adipose tissue development $(15,16)$. In addition, we have recently suggested that Ang II may inhibit lipolysis in abdominal subcutaneous adipose tissue and skeletal muscle in humans (17). However, no firm conclusions about the magnitude of the observed antilipolytic effect of Ang II could be drawn from these in vivo findings using the microdialysis technique, since Ang II-induced vasoconstrictive effects in adipose tissue and skeletal muscle may have masked direct effects on tissue lipolysis to some extent. Taken together, it is intriguing to speculate that Ang II may increase lipid storage in adipose tissue in the short-term by increasing lipogenesis and decreasing lipolysis, and may reduce the buffering capacity of 
adipose tissue for lipid storage in the long-term by inhibiting adipocyte formation, leading to an excessive influx of fatty acids to other tissues.

Thus, with regard to the possible involvement of Ang II in adipose tissue biology and insulin resistance, it is important to better understand the effects of Ang II on fat metabolism in adipose tissue. Therefore, the aim of the present study was to investigate for the first time the direct effects of Ang II on abdominal subcutaneous adipocyte lipolysis in normal-weight and obese subjects.

\section{Methods}

\section{Subjects}

Nine normal-weight $\left(B M I<25 \mathrm{~kg} / \mathrm{m}^{2}\right)$ and seven obese $\left(B M I>30 \mathrm{~kg} / \mathrm{m}^{2}\right)$ male subjects participated in Study 1 (see Study 1). After completion of Study 1, seven additional obese subjects participated in Study 2 (see Study 2). Physical characteristics of the subjects are summarized in table 6.1. Body density was determined by hydrostatic weighing after an overnight fast. Lung volume was measured simultaneously with the helium dilution technique using a spirometer (Volugraph 2000, Mijnhardt, Bunnik, The Netherlands). Body weight was measured with a digital balance, accurate to $0.001 \mathrm{~kg}$ (type E1200; Sauter). Body fat percentage was calculated using the equation of Siri (18). All subjects were in good health as assessed by medical history, were weight stable for at least three months before the study, spent no more than three hours a week in organized sports activities, and were free of any medication. The Medical-Ethical Committee of Maastricht University approved the study protocol, which conformed to the Declaration of Helsinki, and all subjects gave written informed consent before participating in the study.

Table 6.1 Subjects' characteristics

\begin{tabular}{llll}
\hline & Normal-weight & Obese (study 1) & Obese (study 2) \\
\hline Age $(\mathrm{yr})$ & $54 \pm 2$ & $51 \pm 2$ & $52 \pm 4$ \\
Weight $(\mathrm{kg})$ & $76.5 \pm 1.9$ & $112.8 \pm 6.4^{\#}$ & $109.1 \pm 6.3^{*}$ \\
Height $(\mathrm{m})$ & $1.78 \pm 0.03$ & $1.78 \pm 0.02$ & $1.81 \pm 0.02$ \\
BMI $\left(\mathrm{kg} / \mathrm{m}^{2}\right)$ & $24.3 \pm 0.4$ & $35.5 \pm 1.8^{\#}$ & $33.3 \pm 1.9^{*}$ \\
Body fat $(\%)$ & $22.9 \pm 1.3$ & $34.6 \pm 2.7^{\#}$ & $34.4 \pm 3.1^{*}$ \\
\hline
\end{tabular}

$* P<0.005$ and $* P=0.001 *$. normal-weight by unpaired $t$-test. Values are means $\pm S E M$. 


\section{Protocol}

All subjects were asked to refrain from drinking alcohol, smoking, and strenuous exercise for a period of $24 \mathrm{~h}$ before the studies. Subjects came to the laboratory by car or bus in the morning after an overnight fast. Abdominal subcutaneous adipose tissue $(\sim 2 \mathrm{~g})$ was obtained from the paraumbilical region by needle aspiration under local anesthesia (xylocaine $2 \%$ without adrenalin, AstraZeneca BV, Zoetermeer, The Netherlands). It has previously been demonstrated that this form of local anesthesia does not influence adipocyte metabolism (19).

\section{Isolation of adipocytes}

Adipose tissue samples were immediately transported to the laboratory in saline, and adipocytes were isolated from the subcutaneous fat tissue specimen by collagenase treatment, as described previously (20). Briefly, all visible blood vessels and connective tissue were removed, and the fat tissue was incubated in $10 \mathrm{ml}$ Krebs-Ringer phosphate (KRP) buffer ( $\mathrm{pH} 7.4$ ), containing $2 \mathrm{~g} / 1$ collagenase and $40 \mathrm{~g} / 1$ purified bovine serum albumin (BSA), in a shaking bath at $37^{\circ} \mathrm{C}$ for $70 \mathrm{~min}$. Adipocytes were subsequently passed through a $200 \mu \mathrm{m}$ filter (BD Biosciences, Alphen aan den Rijn, The Netherlands) and adipocyte suspensions were washed four times with collagenase-free KRP buffer, supplemented with BSA $(10 \mathrm{~g} / \mathrm{l})$, glucose $(1 \mathrm{~g} / \mathrm{l})$ and ascorbic acid $(0.1 \mathrm{~g} / \mathrm{l})$.

\section{Study 1: effect of Ang II on lipolysis in normal-zveight and obese subjects}

To assess the effect of Ang II on lipolysis, adipocytes obtained from normalweight and obese men were stimulated with a broad range of both physiological and supraphysiological concentrations of Ang II. Briefly, diluted suspensions of adipocytes $(\sim 5,000-10,000$ cells/incubation) were incubated in duplicate for $2 \mathrm{~h}$ at $37^{\circ} \mathrm{C}$ with air as the gas phase in KRP buffer ( $\left.\mathrm{pH} 7.4\right)$, containing bovine serum albumin $(33 \mathrm{~g} / \mathrm{l})$, glucose $(1 \mathrm{~g} / \mathrm{l})$ and ascorbic acid $(0.1 \mathrm{~g} / \mathrm{l})$, in the presence of increasing concentrations of Ang II $\left(10^{-14}-10^{-6} \mathrm{M}\right)$. Baseline incubations (no Ang II stimulation) were performed in quadruplicate. After $2 \mathrm{~h}$ of incubation, cell-free aliquots of the incubation medium were immediately frozen in liquid nitrogen and stored at $-80^{\circ} \mathrm{C}$ until analysis. Glycerol concentration in the medium was used as an indicator of lipolysis, and rates of lipolysis were related to the number of incubated adipocytes during the $2 \mathrm{~h}$ incubation. The same batches of collagenase, bovine serum albumin, and Ang II were used throughout the study. 
Study 2: effects of Ang II on lipolysis in the presence and absence of AT, receptor blockeade in obese subjects

Based on the findings in Study 1, a second study was performed to examine whether the Ang II-induced effects on lipolysis were mediated by the $\mathrm{AT}_{1}$ receptor. In addition, the range of Ang II concentrations used to stimulate the adipocytes was extended to lower Ang II concentrations. To accomplish this, adipocytes obtained from obese men were stimulated with Ang II (10-17-10-6 $\mathrm{M}$ ) using exactly the same methodology as in Study 1. Secondly, adipocytes were incubated with the same concentrations of Ang II in the presence of the $A T_{1}$ receptor blocker losartan $\left(10^{-4} \mathrm{M}\right.$ ) (kindly provided by MSD, Haarlem, The Netherlands). Furthermore, both in the presence and absence of $\mathrm{AT}_{1}$ receptor blockade, adipocytes were incubated with the antilipolytic agent $N^{6}-(2-$ phenylisopropyl)adenosine (PIA: $100 \mathrm{nM}$ ) (Sigma-Aldrich, Zwijndrecht, The Netherlands) as a control point for maximal inhibition of lipolysis in the incubation system when no Ang II was present. The pharmacological agents were added simultaneously at the beginning of the incubation. The same batches of collagenase, bovine serum albumin, Ang II, losartan, and PIA were used throughout the study.

\section{Analyses}

Glycerol concentration in the medium was determined using a sensitive automated bioluminescence method that has been described in detail previously (21). Briefly, this assay involves conversion of glycerol by glycerol kinase, whereby added ATP is consumed. Subsequently, luciferase catalyses the reaction of the remaining ATP with luciferin, leading to the formation of light, which is detected.

\section{Statistical analysis}

Data are presented as mean \pm standard error of the mean (SEM). Lipolytic rates are shown as relative changes from baseline values because of interindividual variation in baseline glycerol concentrations. The effects of Ang II on lipolysis in normalweight and obese subjects (Study 1) and effects of Ang II on lipolysis in the presence or absence of $\mathrm{AT}_{1}$ receptor blockade (Study 2) were compared by twoway repeated measures ANOVA, using dose as within-subject factor and group (Study 1) or treatment (Study 2) as between-subject factor. For both studies, oneway repeated measures ANOVA was performed to identify dose effects. In case of 
significance, post-boc testing was performed using Student's paired $t$-tests to locate significant effects of $\mathrm{Ang}$ II on glycerol concentration. Subjects' characteristics were compared using Student's unpaired t-tests. Calculations were done using SPSS 10.1 (Chicago, IL, USA). $P<0.05$ was considered to be statistically significant.

\section{Results}

Study 1: effects of Ang II on lipolysis in normal-wueight and obese subjects

By definition, obese men had a significantly higher body weight, BMI, and body fat percentage (all $P=0.001$ ) compared with normal-weight men. Average age and height of the groups were similar (table 6.1).

Basal lipolytic rates were not significantly different between normal-weight and obese subjects $\left(4.8 \pm 1.1\right.$ vs. $11.4 \pm 5.1 \mu \mathrm{mol} \cdot 10^{7}$ cells $^{-1} \cdot 2 \mathrm{~h}$ incubation ${ }^{-1}$, respectively, $P=0.24)$. Glycerol concentration in the medium was significantly reduced during stimulation with Ang II both in normal-weight $(P=0.04)$ and obese subjects $(P<0.001)$ (figure 6.1), with no differences between groups $(P=0.40)$. Maximal inhibition of lipolysis by Ang II was $20 \%$. The Ang II-induced inhibition of lipolysis was not clearly dose-dependent in the concentration range used.

Study 2: effects of Ang II on lipolysis in the presence and absence of AT, receptor blockade in obese subjects

Age, weight, height, BMI, and body fat percentage of the obese subjects that participated in Study 2 were comparable with the characteristics of the obese individuals examined in Study 1 (table 6.1).

Mean basal lipolytic rate was $5.0 \pm 1.0 \mu \mathrm{mol} \cdot 10^{7} \mathrm{cells}^{-1} \cdot 2 \mathrm{~h}$ incubation ${ }^{-1}$. In line with the findings in Study 1, glycerol concentration in the medium was significantly reduced during stimulation with Ang II $(P=0.001)$ (figure 6.2). The maximal inhibition of glycerol release by Ang II was $20-25 \%$, which is comparable with the magnitude of the Ang II-induced inhibition of lipolysis observed in Study 1. Using lower doses of Ang II in the second study, a clear dose-dependent reduction of glycerol release by Ang II could be demonstrated, reaching a near-maximal effect at an Ang II dose of 10-12 M. The effects of Ang II on lipolysis were significantly different in the presence or absence of $A \mathrm{~T}_{1}$ receptor blockade, as demonstrated by a significant dose-treatment interaction $(P=0.002)$. Stimulation of 


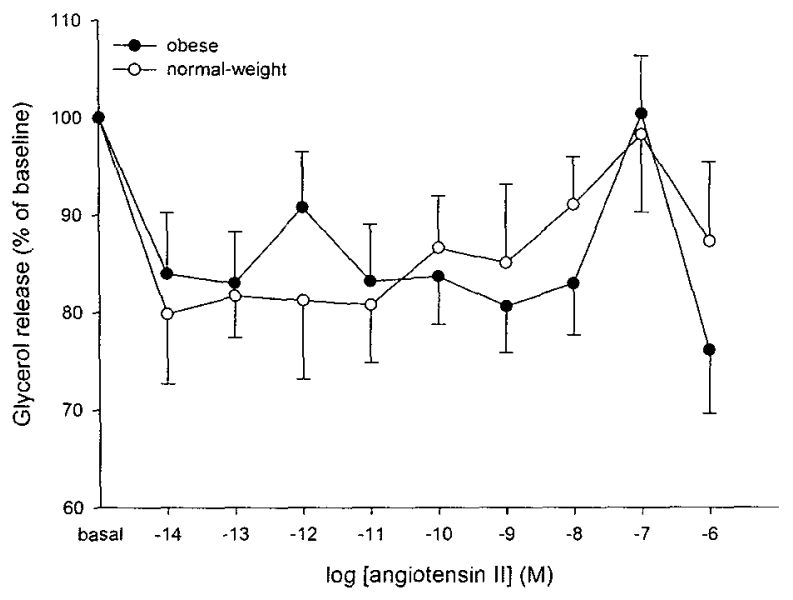

Figure 6.1 Effects of Ang II stimulation on glycerol release from adipocytes obtained from abdominal subcutaneous adipose tissue in nine normal-weight and seven obese subjects. $i$ ing II reduced glycerol release both in normal-weight $(P=0.04$ by one-way repeated measures $A N O V A)$ and obese subjects $(P<0.001$ by one-way repeated measures $A N O V A)$, with no differences between groups $(P=0.40$ by two-way repeated measures ANOVA). Values are means \pm SEM.

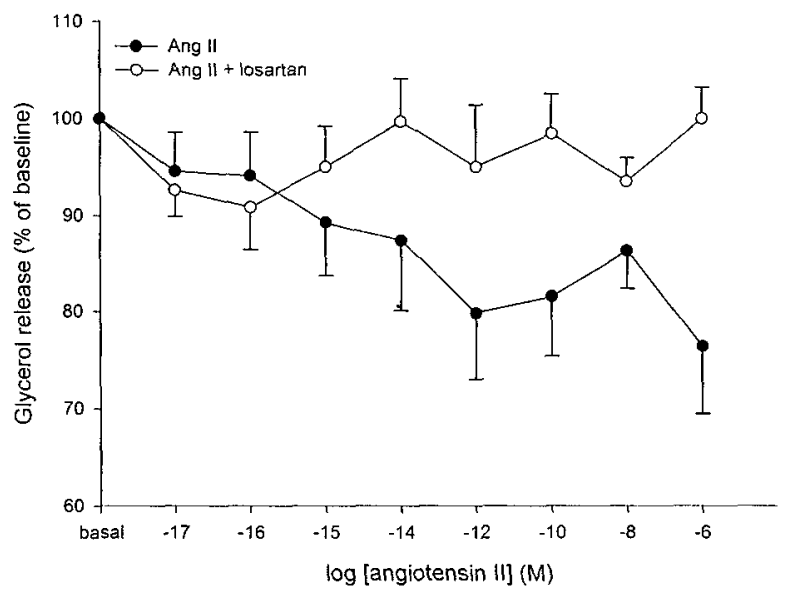

Figure 6.2 Effects of Ang II stimulation on glycerol release from adipocytes obtained from abdominal subcutaneous adipose tissue in seven additional obese subjects in the presence and absence of $A T_{1}$ receptor blockade $\left(10^{-4} \mathrm{M}\right)$. Glycerol release was dose-dependently reduced during stimulation with Ang II ( $P=0.001$ by one-way repeated measures ANOVA). Ang II had no significant effects on lipolysis in the presence of $A T_{1}$ receptor blockade $(P=0.35$ by one-way repeated measures ANOVA). Values are means \pm SEM. 
adipocytes with Ang II in the presence of the $\mathrm{AT}_{1}$ receptor blocker losartan $\left(10^{-4} \mathrm{M}\right)$ had no significant effects on lipolysis $(P=0.35)$ (figure 6.2).

PIA reduced glycerol release by $\sim 40 \%(P<0.01)$. The PIA-induced inhibition of basal lipolysis was comparable in the presence and absence of $\mathrm{AT}_{1}$ receptor blockade $(P=0.66)$.

\section{Discussion}

The present data demonstrate for the first time that Ang II directly inhibits lipolysis in abdominal subcutaneous adipocytes in humans. Ang II inhibited lipolysis to the same extent $(\sim 20 \%)$ in normal-weight and obese subjects (Study 1). In agreement with these findings, a maximal reduction of basal lipolysis of $\sim 20$ $25 \%$ was found after stimulation of adipocytes with Ang II in an additional group of obese subjects (Study 2). Using lower doses of Ang II in the second study, a clear dose-dependent reduction of lipolysis by Ang II could be demonstrated. The antilipolytic effects of Ang II were completely abolished by $\mathrm{AT}_{1}$ receptor blockade, clearly indicating that the Ang II-induced inhibition of lipolysis is mediated through the $\mathrm{AT}_{1}$ receptor.

Adipocytes were also incubated with the antilipolytic agent PIA (100 nM), which was used as a reference point for maximal inhibition of lipolysis in the incubation system, since it has been shown before that near-maximal inhibition of lipolysis in the incubation system can be achieved using this dose of PIA (22). PIA reduced basal lipolytic rate by $\sim 40 \%$, indicating that the observed $\sim 20-25 \%$ reduction of glycerol release after Ang II stimulation reflects a substantial inhibition of lipolysis in the incubation system ( $50 \%$ of maximal PIA-induced antilipolytic response). The normal physiological concentration of Ang II in the circulation is about $10 \mathrm{pM}$ (23). Because stimulation of adipocytes with physiological concentrations of $A$ ing II already evoked near-maximal inhibition of lipolysis in the present studies, our data suggest that Ang II may exert a tonic suppression of lipolysis in vivo in humans.

To the best of our knowledge, the direct effects of Ang II on lipolysis in adipose tissue have never been assessed before using an in vitro approach. The present data are in accordance with recent in vivo findings using microdialysis, suggesting that local Ang II stimulation inhibits lipolysis and decreases local nutritive blood flow in abdominal subcutaneous adipose tissue and skeletal muscle in normal-weight and obese subjects at concentrations corresponding with physiological concentrations of Ang II (17). In contrast, Ang II had no significant effect on the release of free fatty acids from human adipocytes of obese women when 
co-incubated with the $\beta$-adrenergic agonist isoprenaline or insulin (24). Apart from possible gender differences in the effect of Ang II on lipolysis, an explanation for these findings could be that the isoprenaline dose used was too high to observe an antilipolytic effect of Ang II, as it has been demonstrated previously that this dose of isoprenaline evokes near-maximal stimulation of lipolysis (25). Likewise, insulin, which is the most potent antilipolytic agent in adipose tissue, already evoked an inhibition of lipolysis at the lowest dose used. Thus, these strong lipolytic and antilipolytic agents may have masked a less pronounced antilipolytic effect of Ang II in that study. Chronic infusion of a very high dose of Ang II in rats, which was used as a model for increased activity of the RAS in cachectic patients with advanced heart failure, increased lipolysis in some but not all fat depots (26). The chronic high dose of systemically infused Ang II increased plasma Ang II concentrations up to 8-fold, resulting in substantial activation of the sympathetic nervous system, as shown by high interstitial noradrenaline concentrations. However, this model for advanced heart failure in cachectic patients does not reflect the effect of Ang II on lipolysis under physiological conditions in healthy humans. In addition, care has to be taken in extrapolating lipolysis findings in rodents to physiology in humans, as substantial differences in the expression and thus activation of (anti)lipolytic receptors exist between species (26).

The Ang II-induced inhibition of lipolysis that was observed in the present study may contribute to a decreased mobilization of fatty acids from adipose tissue in wivo. In line with a hypertrophic effect of Ang II, it has been shown that Ang II exerts direct lipogenic effects in 3T3-L1 preadipocytes and human adipocytes (14). Thus, both antilipolytic and lipogenic effects of Ang II may contribute to an increased fat storage in adipose tissue, and may play a role in the expansion of fat mass in obesity. In support of these findings, the RAS has been shown to play a role in adipose tissue development in mice $(15,16)$. Furthermore, it has been shown that Ang II inhibits differentiation of human preadipocytes to mature adipocytes (13), which may affect the buffering capacity for lipid storage in adipose tissue. Taken together, Ang II may increase lipid storage in adipose tissue in the short-term, possibly contributing to the expansion of fat mass. However, in the long-term, inhibition of adipocyte formation by Ang II may further reduce the buffering capacity of adipose tissue for lipid storage, which may consequently result in an excessive influx of fatty acids to other tissues (12). A large number of observations suggest that accumulation of triglycerides (TAG) in tissues like skeletal muscle (27-29), liver (30,31), and pancreatic islets (32), may play an important role in the development of insulin resistance in obesity. Ang II actions 
in adipose tissue may contribute to ectopic fat deposition in obese subjects in particular, because adipocytes are hypertrophic in obesity and therefore have a reduced capacity for further lipid storage.

This study was not designed to examine underlying mechanisms for the observed effects, but was focussed on lipolysis as cellular end-point. However, identification of molecular mechanisms behind the antilipolytic effect of Ang II in human adipocytes would provide better insight into the interaction of (anti)lipolytic pathways. There are several mechanisms that may explain the observed antilipolytic effect of Ang II. However, at present it is unclear whether Ang II can also affect these pathways in human adipocytes. First, it has been demonstrated that Ang II exerts an inhibitory effect on cAMP concentration $(33,34)$. Secondly, Ang II has been shown to counteract the atrial natriuretic peptide (ANP)stimulated cGMP synthesis (35). Both a reduction of cAMP (36) and cGMP (37) would result in a reduced rate of lipolysis in adipose tissue. Finally, an Ang IIinduced increase in intracellular $\mathrm{Ca}^{2+}$ concentration mediated through the $\mathrm{AT}_{1}$ receptor has been demonstrated $(38,39)$, which may explain a decreased lipolysis in adipocytes (40). Future research is needed to elucidate the pathways by which Ang II inhibits adipose tissue lipolysis in humans.

In conclusion, the present data show for the first time that Ang II directly inhibits abdominal subcutaneous adipocyte lipolysis in normal-weight and obese subjects. The antilipolytic effects of Ang II were completely abolished by $\mathrm{AT}_{1}$ receptor blockade, clearly indicating that these effects are mediated through the $A T_{1}$ receptor. The present findings support the concept that the RAS in adipose tissue serves not only to regulate regional blood flow in adipose tissue, but also participates directly in fat metabolism, which may contribute to the metabolic disturbances seen in obesity and insulin resistance.

\section{Acknowledgements}

The authors would like to thank Kerstin Wåhlén, Eva Sjölin and Freek Bouwman for excellent technical assistance. Losartan was kindly provided by Merck Sharp \& Dohme (Haarlem, The Netherlands). 


\section{References}

1. Lafontan M. Fat cells: afferent and efferent messages define new approaches to treat obesity. Annu Rev Pharmacol Toxicol 2005;45:119-46.

2. Arner P. Insulin resistance in type 2 diabetes - role of the adipokines. Curr Mol Med 2005;5(3):333-9.

3. Kershaw EE, Flier JS. Adipose tissuc as an endocrine organ. J Clin Endocrinol Metab 2004;89(6):2548-56.

4. Danforth E, Jr. Failure of adipocyte differentiation causes type II diabetes mellitus? Nat Genet 2000;26(1):13.

5. Okuno A, Tamemoto H, Tobe K, Ueki K, Mori $Y$, Iwamoto K, et al. Troglitazone increases the number of small adipocytes without the change of white adipose tissue mass in obese Zucker rats. J Clin Invest 1998;101(6):1354-61.

6. Machann J, Haring $\mathrm{H}$, Schick F, Stumvoll M. Intramyocellular lipids and insulin resistance. Diabetes Obes Metab 2004;6(4):239-48.

7. Schling $P$, Schafer $T$. Human adipose tissue cells keep tight control on the angiotensin II levels in their vicinity. J Biol Chem 2002;277(50):48066-75.

8. Karlsson C, Lindell K, Ottosson M, Sjostrom L, Carlsson B, Carlsson L.M. Human adipose tissue expresses angiotensinogen and enzymes required for its conversion to angiotensin II. J Clin Endoctinol Metab 1998;83(11):3925-9.

9. Crandall DL, Herzlinger HE, Saunders BD, Armellino DC, Kral JG. Distribution of angiotensin II receptors in rat and human adipocytes. J Lipid Res 1994;35(8):1378-85.

10. Goossens GH, Blaak EE, van Baak MA. Possible involvement of the adipose tissue reninangiotensin system in the pathophysiology of obesity and obesity-related disorders. Obes Rev 2003;4(1):43-55.

11. Strazzullo P, Galletti F. Impact of the renin-angiotensin system on lipid and carbohydrate metabolism. Curr Opin Nephrol Hypertens 2004;13(3):325-32.

12. Sharma AM, Janke J, Gorzelniak K, Engeli S, Luft FC. Angiotensin blockade prevents type 2 diabetes by formation of fat cells. Hypertension 2002;40(5):609-11.

13. Janke J, Engeli S, Gorzelniak K, Luft FC, Sharma AM. Mature adipocytes inhibit in witro differentiation of human preadipocytes via angiotensin type 1 receptors. Diabetes 2002;51(6):1699-707.

14. Jones BH, Standridge MK, Moustaid N. Angiotensin II increases lipogenesis in 3T3-L1 and human adipose cells. Endocrinology 1997;138(4):1512-9.

15. Massiera F, Bloch-Faure M, Ceiler D, Murakami K, Fukamizu A, Gasc JM, et al. Adipose angiotensinogen is involved in adipose tissue growth and blood pressure regulation. Faseb J 2001;15(14):2727-9.

16. Massiera F, Seydoux J, Geloen A, Quignard-Boulange A, Turban S, Saint-Marc P, et al. Angiotensinogen-deficient mice exhibit impairment of diet-induced weight gain with alteration in adipose tissue development and increased locomotor activity. Endocrinology 2001;142(12):5220-5.

17. Goossens GH, Blaak EE, Saris WH, Van Baak MA. Angiotensin II-induced effects on adipose and skeletal muscle tissue blood flow and lipolysis in normal-weight and obese subjects. J Clin Endocrinol Metab 2004;89(6):2690-6.

18. Siri WE. The gross composition of the body. Adv Biol Med Physiol 1956;4:239-280.

19. Kolaczynski JW, Morales LM, Moore JH, Jr., Considine RV, Pietrzkowski Z, Noto PF, et al. A new technique for biopsy of human abdominal fat under local anaesthesia with Lidocaine. Int J Obes Relat Metab Disord 1994;18(3):161-6.

20. Rodbell M. Metabolism of isolated fat cells: effects of hormones on glucose metabolism and lipolysis. J Biol Chem 1964;239:375-380.

21. Hellmer J, Amer P, Lundin A. Automatic luminometric kinetic assay of glycerol for lipolysis studies. Anal Biochem 1989;177(1):132-7. 
22. Johnson JA, Fried SK, Pi-Sunyer FX, Albu JB. Impaired insulin action in subcutaneous adipocytes from women with visceral obesity. Am J Physiol Endocrinol Metab 2001;280(1):Е40-9.

23. Campbell DJ, Kladis $A$. Simultaneous radioimmunoassay of six angiotensin peptides in arterial and venous plasma of man. J Hypertens 1990;8(2):165-72.

24. Perry CG, Palmer T, Cleland SJ, Morton IJ, Salt IP, Petrie JR, et al. Decreased insulin sensitivity during dietary sodium resttiction is not mediated by effects of angiotensin II on insulin action. Clin Sci (Lond) 2003;105(2):187-94.

25. van Harmelen $V$, Lonnquist $F$, Thorne $A$, Wennlund $A$, Large $V$, Reynisdottir $S$, et al. Noradrenaline-induced lipolysis in isolated mesenteric, omental and subcutancous adipocytes from obese subjects. Int J Obes Relat Metab Disord 1997;21(11):972-9.

26. Cabassi A, Coghi P, Govoni P, Barouhiel E, Spcroni E, Cavazzini S, et al. Sympathetic modulation by carvedilol and losartan reduces angiotensin II-mediated lipolysis in subcutancous and visceral fat. ] Clin Endocrinol Metab 2005.

27. Jacob S, Machann J, Rett K, Brechtel K, Volk A, Renn W, et al. Association of increased intramyocellular lipid content with insulin resistance in lean nondiabetic offspring of type 2 diabetic subjects. Diabetes 1999;48(5):1113-9.

28. Forouhi NG, Jenkinson $G$, Thomas EL, Mullick S, Mierisova S, Bhonsle U, et al. Relation of triglyceride stores in skcletal muscle cells to central obesity and insulin sensitivity in European and South $A$ sian men. Diabetologia 1999;42(8):932-5.

29. Pan DA, Lillioja S, Kriketos $A D$, Milner MR, Baur LA, Bogardus C, et al. Skeletal muscle triglyceride levels are inversely related to insulin action. Diabetes 1997;46(6):983-8.

30. Bjorntorp P. Liver triglycerides and metabolism. Int J Obes Relat Metab Disord 1995;19(12):839-40.

31. Banerji MA, Buckley MC, Chaiken RL, Gordon D, Lebovitz HE, Kral JG. Liver fat, scrum triglycerides and visceral adipose tissue in insulin-sensitive and insulin-resistant black men with NIDDM. Int J Obes Relat Metab Disord 1995;19(12):846-50.

32. Koyama $K$, Chen $G$, Lee $Y$, Unger $R H$. Tissue triglycerides, insulin resistance, and insulin production: implications for hyperinsulinemia of obesity. Am J Physiol 1997;273(4 Pt 1):E70813.

33. Ardaillou R. Angiotensin II receptors. J Am Soc Nephrol 1999;10 Suppl 11:S30-9.

34. Klett C, Nobiling R, Gierschik P, Hackenthal E. Angiotensin II stimulates the synthesis of angiotensinogen in hepatocytes by inhibiting adenylylcyclase activity and stabilizing angiotensinogen mRN $A$. J Biol Chem 1993;268(33):25095-107.

35. Golos M, Lewko B, Bryl E, Witkowski JM, Dubaniewicz A, Olszewska $A$, et al. Effect of angiotensin II on ANP-dependent guanylyl cyclase activity in cultured mouse and rat podocytes. Kidncy Blood Press Res 2002;25(5):296-302.

36. Lafontan M, Berlan M. Fat cell adrenergic receptors and the control of white and brown fat cell function. J Lipid Res 1993;34(7):1057-91.

37. Sengenes C, Berlan M, De Glisezinski I, Lafontan M, Galitzky J. Natriuretic peptides: a new lipolytic pathway in human adipocytes. Faseb ] 2000;14(10):1345-51.

38. Chappell MC, Jacobsen DW, Tallant EA. Characterization of angiotensin II receptor subtypes in pancreatic acinar $A R 42\}$ cells. Peptides 1995;16(4):741-7.

39. Touyz RM, Schiffrin EL. Signal transduction mechanisms mediating the physiological and pathophysiological actions of angiotensin II in vascular smooth muscle cells. Pharmacol Rev 2000;52(4):639-72.

40. Xue B, Moustaid N, Wilkison WO, Zemel MB. The agouti gene product inhibits lipolysis in human adipocytes via a $\mathrm{Ca}^{2+}$-dependent mechanism. Faseb J 1998;12(13):1391-6. 



\section{7}

\section{ACE inhibition and insulin sensitivity in}

obese insulin resistant subjects:

a double-blind placebo-controlled randomized trial to examine underlying mechanisms

Gijs H. Goossens ${ }^{1,2}$, Ellen E. Blaak ${ }^{1,2}$, Paul M. Schiffers ${ }^{3}$, Wim H.M. Saris ${ }^{1}$ and Marleen A. van Baak

${ }^{1}$ Department of Human Biology, Nutrition and Toxicology Research Institute Maastricht (NUTRIM), Maastricht University, Maastricht, The Netherlands

${ }^{2}$ Wageningen Centre for Food Sciences (WCFS), Wageningen, The Netherlands.

${ }^{3}$ Department of Pharmacology and Toxicology, Cardiovascular Research Institute Maastricht (CARIM), Maastricht University, Maastricht, The Netherlands. 


\section{Abstract}

This study was designed to investigate the effect of short-term ACE inhibitor treatment on insulin sensitivity and to examine for the first time possible underlying metabolic and hemodynamic effects in obese, insulin resistant subjects. A randomized, double-blind placebo-controlled trial was performed in 18 obese, insulin resistant men (age, $53 \pm 2 \mathrm{yr}$; BMI, $32.6 \pm 0.8 \mathrm{~kg} / \mathrm{m}^{2}$; HOMA-IR, 5.6 \pm 0.5 ; SBP, $140.8 \pm 3.2 ; \mathrm{DBP}, 88.8 \pm 1.6 \mathrm{mmHg}$ ), free of any medication, to examine the effects of 2-week ACE inhibitor treatment (ramipril, $5 \mathrm{mg} / \mathrm{d}$ ) on insulin sensitivity, forearm blood flow, substrate fluxes across the forearm, whole-body substrate oxidation, and intramuscular triacylglycerol (IMTG) content.

Ramipril treatment significantly decreased ACE activity compared with placebo $(-22.0 \pm 1.7$ vs. $0.2 \pm 1.1 \mathrm{U} / 1$, respectively, $P<0.001)$, resulting in a significantly reduced blood pressure ( $\mathrm{SBP},-10.8 \pm 2.1$ vs. $-2.7 \pm 2.0 \mathrm{mmHg}$, respectively, $P=0.01$; DBP, $-10.1 \pm 1.3$ vs. $-4.2 \pm 2.1 \mathrm{mmHg}$, respectively, $P=0.03$ ). Ramipril treatment had no significant effect on whole-body insulin-mediated glucose disposal (before: $17.9 \pm 2.0 v$ s. after: $\left.19.1 \pm 2.4 \mu \mathrm{mol} \cdot \mathrm{kg} \mathrm{bw}^{-1} \cdot \mathrm{min}^{-1}, P=0.44\right)$, insulin-mediated glucose uptake across the forearm (before: $1.82 \pm 0.39 \nu$ s. after: $1.92 \pm 0.29 \mu \mathrm{mol} \cdot 100 \mathrm{ml}$ forearm tissue ${ }^{-1} \cdot \mathrm{min}^{-1}, P=0.81$ ), and IMTG content (before: $45.4 \pm 18.8$ is. after: $48.8 \pm 27.5 \mu \mathrm{mol} \cdot \mathrm{mg}$ dry muscle $\left.{ }^{-1}, P=0.92\right)$. Furthermore, the increase in carbohydrate oxidation $(P<0.001)$ and forearm blood flow $(P<0.01)$, and the decrease in fat oxidation $(P<0.001)$ after insulin stimulation were not significantly different between treatments.

In conclusion, short-term ramipril treatment adequately reduces ACE activity and blood pressure, but has no significant effects on insulin sensitivity, forearm blood flow, substrate fluxes across the forearm, whole-body substrate oxidation, and IMTG content in obese, insulin resistant subjects. 


\section{Introduction}

Type 2 diabetes mellitus is associated with an increased cardiovascular risk, which is amplified in the presence of hypertension (1). On the other hand, hypertension is a strong predictor of the development of diabetes, indicated by a 2.5 -fold increased risk for developing type 2 diabetes in hypertensive compared with normotensive individuals (2).

Angiotensin-converting enzyme (ACE) inhibitors are increasingly used as first-line therapy for hypertension in patients with type 2 diabetes mellitus, mainly because they have been shown to reduce both microvascular and macrovascular complications in diabetes $(1,3)$. On the other hand, recent clinical trials have suggested that agents interfering with the renin-angiotensin system (RAS), such as ACE inhibitors and angiotensin II (Ang II)-type 1 ( $\left.A T_{1}\right)$ receptor blockers, may reduce the incidence of diabetes in patients with or without hypertension and at high risk of developing diabetes (4). These observations have led to discussion about the underlying mechanisms for this putative effect.

The protective effect of a reduction in RAS activity against the development of diabetes has mainly been explained by hemodynamic and metabolic effects that decrease insulin resistance and improve insulin secretion. First, hemodynamic effects of ACE inhibition may contribute to improved glucose disposal by decreasing Ang II-induced vascular resistance in skeletal muscle (5) and the pancreas (6), thereby increasing blood flow through these tissues, resulting in improved insulin wash-out from the pancreas and increased delivery of glucose and insulin to the periphery. Secondly, the effects of a reduced RAS activity on insulin sensitivity have largely been attributed to improvements in peripheral glucose metabolism (7-13) and insulin signal transduction $(14,15)$. Thirdly, similar to the working mechanism of the thiazolidinedione (TZD) insulin sensitizers, it has recently been hypothesized that blockade of the RAS may prevent diabetes by promoting the recruitment and differentiation of adipocytes (16), which may counteract deposition of triacylglycerol (TAG) in other tissues such as skeletal muscle, pancreas, and liver, thereby improving insulin sensitivity. Finally, RAS blockade may improve pancreatic islet morphology and function, thereby increasing insulin secretion (6). However, the beneficial effects of ACE inhibitors on insulin sensitivity and the reduction in incidence of diabetes have not been shown in all studies (17-22). Importantly, several investigations on the effect of ACE inhibition on insulin sensitivity are based on uncontrolled study designs, 
surrogate markers of insulin sensitivity, and are potentially confounded by the use of additional medication.

Thus, although results are still controversial, RAS blockade may improve insulin resistance in obesity and type 2 diabetes. Despite this, few studies have been performed to examine the effect of RAS blockade on both insulin sensitivity and possible underlying mechanisms in vivo in humans. To our knowledge, this is the first well-controlled study designed to investigate the effects of short-term ACE inhibitor treatment on whole-body insulin sensitivity, forearm blood flow, substrate fluxes across the forearm, substrate oxidation, and intramuscular triacylglycerol (IMTG) content in obese, insulin resistant subjects.

\section{Methods}

\section{Subjects}

18 non-smoking, obese, insulin resistant male subjects participated in this study. Subjects' characteristics are summarized in table 7.1. Predefined entry criteria at screening were $\mathrm{BMI}>30 \mathrm{~kg} / \mathrm{m}^{2}$, mean supine blood pressure (in triplicate after 10 min of supine rest) above $120 / 80 \mathrm{mmHg}$, and insulin resistance calculated by homeostasis model assessment (HOMA-IR) (23) (subjects were included when HOMA-IR>2.2). Exclusion criteria were cardiovascular disease, diabetes mellitus, cancer, asthma or bronchitis, low-sodium diet, participation in organized sports activities more than three hours a week, or the use of any medication. The Medical-Ethical Committee of Maastricht University approved the study protocol, and all subjects gave written informed consent before participating in the study.

\section{Study design}

This study was performed according to a double-blind placebo-controlled randomized design. Following screening, subjects were randomly divided into two groups. One group received the ACE inhibitor ramipril $(5 \mathrm{mg}$ daily, single oral dose; Sanofi-aventis, Gouda, The Netherlands) for 14 days, while the control group received placebo treatment during this period.

Subjects came to the laboratory by car or bus in the morning after an overnight fast on two different occasions (before and after treatment) and were studied at rest. Subjects were asked to refrain from drinking alcohol for a period of $24 \mathrm{~h}$ before each study day, to perform no strenuous exercise for a period of $48 \mathrm{~h}$ before 
Table 7.1 Subjects' characteristics before treatment

\begin{tabular}{lll}
\hline & Placebo $(n=9)$ & Ramipril $(n=9)$ \\
\hline Age $(\mathrm{yr})$ & $53 \pm 3$ & $52 \pm 3$ \\
Weight $(\mathrm{kg})$ & $101.2 \pm 4.7$ & $108.0 \pm 4.5$ \\
Height $(\mathrm{m})$ & $1.76 \pm 0.03$ & $1.82 \pm 0.02$ \\
BMI $\left(\mathrm{kg} / \mathrm{m}^{3}\right)$ & $32.4 \pm 0.9$ & $32.8 \pm 1.4$ \\
Waist circumference (cm) & $117.9 \pm 4.5$ & $115.3 \pm 3.6$ \\
Hip circumference (cm) & $112.0 \pm 3.8$ & $110.2 \pm 2.3$ \\
SBP (mmHg) & $144 \pm 5$ & $138 \pm 4$ \\
DBP (mmHg) & $90 \pm 2$ & $88 \pm 2$ \\
Fasting glucose (mmol/l) & $6.0 \pm 0.1$ & $5.9 \pm 0.1$ \\
Fasting insulin (mU/l) & $21.8 \pm 3.0$ & $20.9 \pm 1.9$ \\
HOMA-IR & $5.8 \pm 0.8$ & $5.5 \pm 0.6$ \\
\hline
\end{tabular}

BMI, body mass index $\left(\mathrm{kg} / \mathrm{m}^{2}\right.$ ); SBP, systolic blood pressurc ( $\mathrm{mmnHg}$ ); DBP, diastolic blood pressure (mmHg); HOMA-IR, insulin resistance index by homeostasis model assessment. V'alues are means \pm SEM.

each study day, and not to change their dietary and physical activity habits throughout the study. On arrival, height, weight, waist and hip circumferences were measured. Body weight was measured with a digital balance, accurate to 0.001 $\mathrm{kg}$ (type E1200, August Sauter GmbH, Albstadt, Germany). After $30 \mathrm{~min}$ of supine rest blood pressure was measured with an electronic auscultatory blood pressure reading machine (Omron Healthcare Europe BV, Hoofddorp, The Netherlands). The first blood pressure reading was discarded and the mean of the next three consecutive readings with a coefficient of variation below $15 \%$ was used, with additional readings if required. The same blood pressure reading machine was used throughout the study. Before and after treatment, insulin sensitivity was determined by a $3 \mathrm{~h}$ hyperinsulinemic-euglycemic clamp, using a modification of the method described by DeFronzo et al. (24). A muscle biopsy was collected from the m. vastus lateralis under local anesthesia using needle biopsy at baseline for the measurement of intramuscular triacylglycerol (IMTG) content.

\section{Hyperinsulinemic-euglycenic clamp}

Three cannulas were inserted before the start of the experiment. A 20-gauge cannula was inserted retrogradely into a superficial dorsal hand vein. This vein was heated in a hot box $\left(60^{\circ} \mathrm{C}\right)$ for at least 20 min to obtain arterialized venous blood. In the same arm, a second cannula was introduced anterogradely in an antecubital vein of the forearm for the infusion of $20 \%$ glucose (IVAC 560 pump, IVAC, San 
Diego, CA) and insulin (40 $\mathrm{mU} \cdot \mathrm{m}^{-2} \cdot \mathrm{min}^{-1}$, Actrapid, Novo Nordisk Farma BV, Alphen aan den Rijn, The Netherlands, using a Harvard microinfusion pump, Plato BV, Diemen, The Netherlands). In the contralateral arm, a third cannula was inserted retrogradely in an antecubital vein of the forearm to obtain deep venous blood, draining forearm muscle. A small amount of blood was drawn from the dorsal hand vein every five minutes throughout the clamp to determine glucose concentration (EML 105, Radiometer, Copenhagen, Denmark). The amount of glucose infused was adjusted to maintain euglycemia at $5.0 \mathrm{mmol} / \mathrm{l}$.

Before the start of the clamp (t-30, t-20, t-10) and at three time points during the last $30 \mathrm{~min}$ of the clamp ( $\mathrm{t} 150, \mathrm{t} 160, \mathrm{t} 170)$, when a steady-state in glucose concentration was reached, arterialized and deep venous blood samples were simultaneously collected to assess arterio-venous differences of metabolites across the forearm. At the same time points, forearm blood flow (FBF) was measured to calculate substrate fluxes across the forearm. Positive fluxes indicate net uptake from plasma, whereas negative fluxes indicate net tissue release. Mean fasting values were calculated by averaging time-points $t-30, t-20$, and $t-10$, whereas mean insulin-stimulated values were calculated by averaging time-points $t 150, t 160$, and t170. Furthermore, energy expenditure and substrate oxidation were measured at baseline ( $t-30-0)$ and during the last 30 min of the clamp ( $t 150-180)$.

\section{Energy expenditure and substrate oxidation}

Oxygen consumption and carbon dioxide production were measured using a computerized open-circuit ventilated hood system. Whole-body energy expenditure and respiratory quotient $(\mathrm{RQ})$ were calculated according to the formulas of Weir (25). Total carbohydrate and fat oxidation were calculated according to the following equations (26):

$\mathrm{CHO}(\mathrm{g} / \mathrm{min})=4.55 \mathrm{VCO}_{2}-3.21 \mathrm{VO}_{2}-2.87 \mathrm{n}$

Fat $(\mathrm{g} / \mathrm{min})=1.67 \mathrm{VO}_{2}-1.67 \mathrm{VCO}_{2}-1.92 \mathrm{n}$

where $\mathrm{VO}_{2}$ is oxygen consumption $(1 / \mathrm{min}), \mathrm{VCO}_{2}$ is carbon dioxide production $(1 / \mathrm{min})$, and $\mathrm{n}$ is nitrogen excretion $(\mathrm{g} / \mathrm{min})$. For the calculation of nitrogen excretion it was estimated that $15 \%$ of total energy expenditure was derived from protein oxidation, with $1 \mathrm{~g}$ of nitrogen arising from $6.25 \mathrm{~g}$ protein. 


\section{Forearm blood flow}

FBF was measured by venous occlusion plethysmography (EC5R plethysmograph, Hokanson, Bellevue, USA) using mercury-in-silastic strain gauges applied to the widest part of the forearm (27). During measurement periods, the hand circulation was occluded by rapid inflation of a sphygmomanometer cuff (E20 rapid cuff inflator, Hokanson, Bellevue, USA) placed around the wrist to a pressure of 200 $\mathrm{mmHg}$. In this way, FBF can be assessed without interference of the hand circulation. A cuff placed around the upper arm was inflated to $45 \mathrm{mmHg}$ (and deflated) to achieve venous occlusion and obtain plethysmographic recordings. During venous occlusion, the plethysmographic recordings reflect the rate of arterial inflow, indicating FBF.

\section{Biochemical measurements}

Blood samples were collected into syringes containing either EDTA, heparine, or Ang II buffer (28), and immediately transferred into ice-chilled polypropylene tubes. Blood samples were then centrifuged $\left(3000 \mathrm{rpm}, 4^{\circ} \mathrm{C}, 10\right.$ minutes $)$ and plasma was immediately frozen in liquid nitrogen and stored at $-80^{\circ} \mathrm{C}$ until analysis. A small proportion of blood was used for blood gas analysis to ensure adequate arterialization (oxygen saturation $>95 \%$ ) (ABL 510, Radiometer, Copenhagen, Denmark). The hematocrit $(\mathrm{Ht})$ was measured using an $\mathrm{Ht}$-centrifuge.

Ang II was measured by a standard radioimmunoassay (Peninsula Laboratories Europe, St. Helens, UK) following C-18 Sep-Pak (Waters-Millipore) extraction of the peptide. Intra- and interassay coefficients of variation were $4.6 \%$ and $7.7 \%$, respectively. Plasma ACE activity was determined by a colorimetric assay (ACE color, Fujirebio Inc., Japan). Intra- and interassay coefficients of variation were $3.9 \%$ and $7.1 \%$, respectively. For the measurement of other metabolites, blood samples were collected in EDTA containing syringes. Plasma glucose (ABX Pentra Glucose HK CP, Radiometer, Copenhagen, Denmark), free fatty acid (FFA) (Wako NEFA C kit, Wako Chemicals, Neuss, Germany), glycerol (EnzyPlus Glycerol Kit, Diffchamp, Västra Frölunda, Sweden), and triacylglycerol (ABX Triglyceriden 100, Radiometer, Copenhagen, Denmark) concentrations were measured using standard enzymatic methods. Plasma insulin concentrations were measured by a specific double antibody radioimmunoassay for human insulin (Linco Research Inc., St. Charles, Missouri, USA). 


\section{IMTG content}

Muscle biopsies were immediately frozen in liquid nitrogen and stored at $-80^{\circ} \mathrm{C}$ until analysis. The biopsies were freeze-dried, dissected free of blood, connective tissue and visible fat under magnification, and powdered for analysis of total intramuscular triacylglycerol (IMTG) content. IMTG was extracted from a 2-6 mg sample of powdered muscle using chloroform-methanol (29). After phospholipids removal using silicic acid, the extracts were saponified with ethanolic $\mathrm{KOH}$ at $60^{\circ} \mathrm{C}$ for $1 \mathrm{~h}$, and neutralized with $\mathrm{MgSO}_{4}$. Triacylglycerol concentration was then determined by assaying the free glycerol fluorometrically using a standard glycerol kit (Boehringer, Mannheim, Germany), but with adjusted concentrations of $\mathrm{NADH}$, enzymes and buffer, to achieve accurate fluorometric detection.

\section{Statistics}

Data are presented as mean \pm standard error of the mean (SEM). Overall effects of ramipril treatment compared with placebo were analysed using repeated-measures ANOVA to identify time effects, treatment effects, and time and treatment interactions. Changes with time in plasma concentrations, blood pressure, insulin sensitivity, substrate fluxes across the forearm, energy expenditure, substrate oxidation, IMTG content, and forearm blood flow were assessed by two-way repeated-measures ANOVA, using time as within-subject factor and treatment as between-subject factor. Because no significant differences in any of the measured variables were observed between groups at baseline (before the start of treatment), both groups were combined to assess the effect of insulin (hyperinsulinemiceuglycemic clamp) before the start of the treatment period using Student's paired $t$-tests. Calculations were done using SPSS 10.1 for Windows (Chicago, IL, USA). $P<0.05$ was considered to be statistically significant.

\section{Results}

Age, weight, height, BMI, waist and hip circumferences, blood pressure, plasma glucose and insulin concentrations, and HOMA-IR were comparable between the ramipril and placebo group before the start of treatment (table 7.1), indicating that both treatment groups were well-matched after randomization. No changes in weight, BMI, or waist circumference were observed at the end of either treatment. 


\section{Plasma ACE and Ang II concentrations}

Ramipril treatment significantly reduced plasma ACE activity compared with placebo $(P<0.001)$ (figure 7.1). Insulin caused a slight but significant decrease in ACE activity (baseline: $27.6 \pm 1.5 v$ s. insulin: $22.1 \pm 1.4 \mathrm{U} / 1, P<0.001$ ). Plasma Ang II concentrations were comparable between the ramipril and placebo group before treatment $(10.6 \pm 2.6$ vs. $8.6 \pm 2.3 \mathrm{pmol} / 1, P=0.57$, respectively). No significant differences in plasma Ang II concentrations were observed after ramipril treatment compared with placebo $(P=0.22)$.

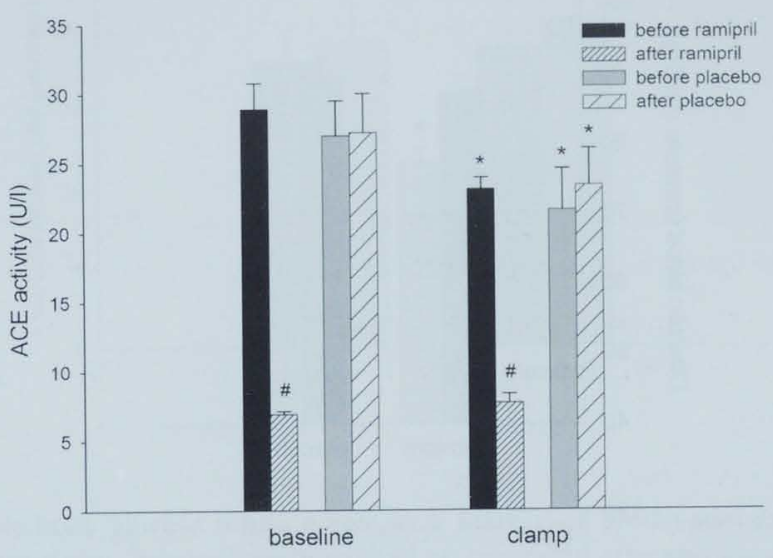

Figure 7.1 Plasma ACE activity before and after treatment. Ramipril treatment significantly decreased ACE activity compared with placebo $(P<0.001$ by two-way repeated measures ANOVA). Student's paired $t$-test, ${ }^{*} P<0.05 \mathrm{vs}$. baseline, ${ }^{\#} P<0.001 \mathrm{v}$ s. before treatment. Values are means $\pm S E M$.

\section{Blood pressure}

Ramipril treatment significantly reduced systolic $(P=0.01)$, diastolic $(P=0.03)$, and mean arterial blood pressure $(P=0.01)$ compared with placebo (figure 7.2). Systolic blood pressure was reduced by $10.8 \mathrm{mmHg}(137.7 \pm 3.9$ vs. $126.9 \pm 3.2 \mathrm{mmHg}$, $P<0.001)$, and diastolic blood pressure by $10.2 \mathrm{mmHg}(87.6 \pm 2.3$ vs. $77.4 \pm 2.1$ $\mathrm{mmHg}, P<0.001)$ after ramipril treatment. Placebo treatment did not significantly alter blood pressure. 

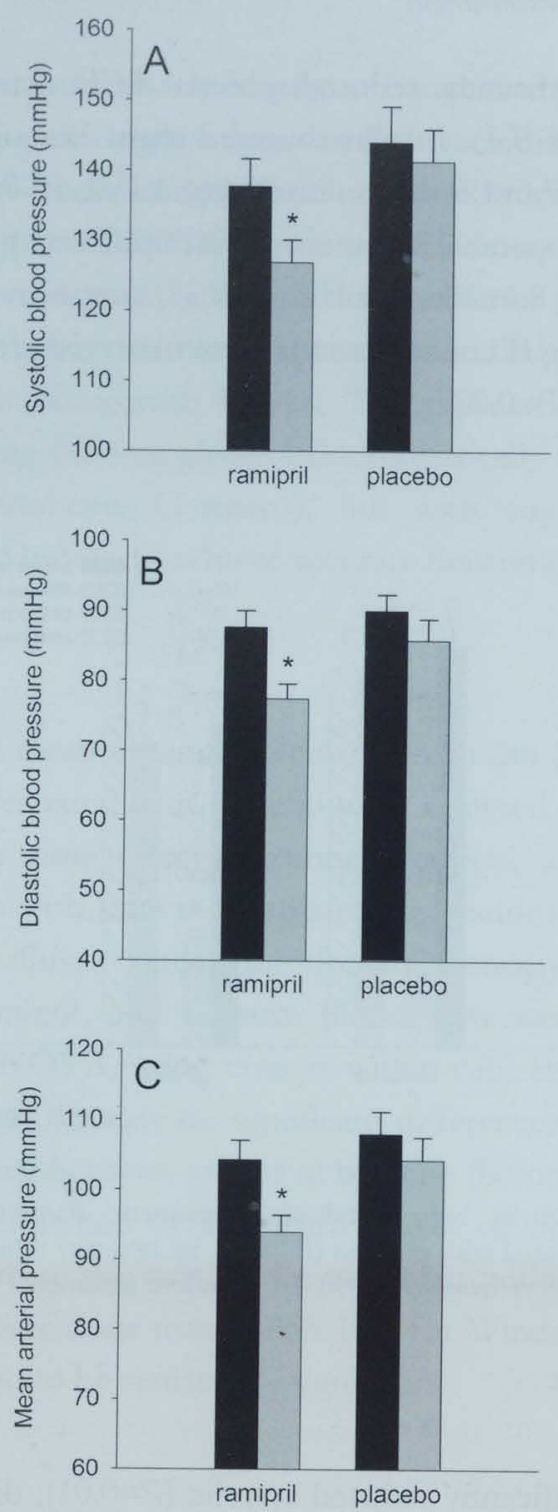

before treatment after treatment

Figure 7.2 Systolic (A), diastolic (B), and mean arterial blood pressure (C) before and after treatment. Ramipril treatment significantly reduced systolic ( $P=0.01$ by two-way repeated measures ANOVA), diastolic $(P=0.03$ by two-way repeated measures ANOVA), and mean arterial blood pressure $(P=0.01$ by two-way repeated measures ANOVA) compared with placebo. Student's paired $t$-test, $* P<0.001$ $v$ s. before treatment. Values are means $\pm \mathrm{SEM}$. 


\section{Whole-body insulin sensitivity}

As expected from screening results, whole-body insulin sensitivity measurements clearly showed that all subjects were insulin resistant. There were no significant differences in whole-body insulin-mediated glucose disposal after ramipril treatment compared with placebo $(P=0.90)$ (figure 7.3 ).

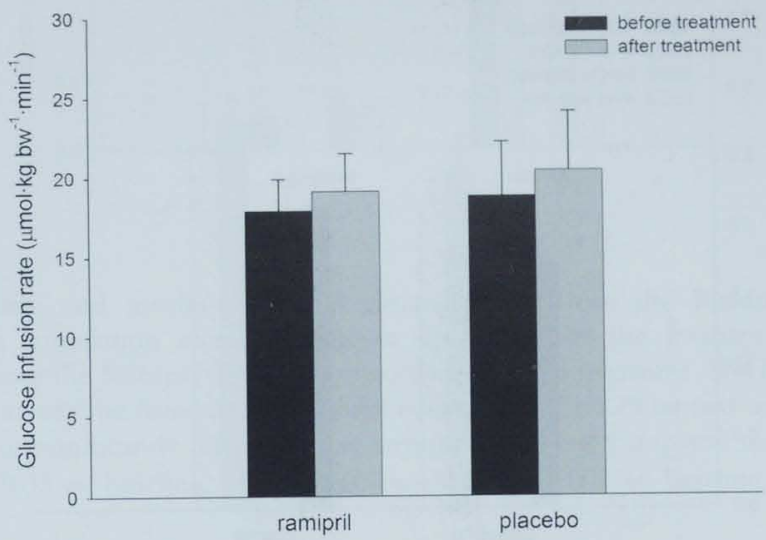

Figure 7.3 Whole-body glucose infusion rate as a marker of insulin-stimulated glucose disposal before and after treatment. Ramipril treatment had no significant effect on insulin-stimulated glucose disposal compared with placebo ( $P=0.90$ by two-way repeated measures ANOVA). Values are means \pm SEM.

Arterialized plasma insulin, glucose, TAG, FFA, and glycerol concentrations

Plasma insulin concentrations increased to a plateau within the first $60 \mathrm{~min}$ of the clamp with no significant differences between treatments and study days at baseline and during hyperinsulinemia (baseline: $21.3 \pm 1.7$ vs. hyperinsulinemia: $119.9 \pm 3.8 \mathrm{mU} / 1, P<0.001)$. Hyperinsulinemia decreased plasma concentrations of glucose (baseline: $5.9 \pm 0.1$ vs. hyperinsulinemia: $5.4 \pm 0.1 \mathrm{mmol} / 1, P=0.001$ ), TAG (baseline: $1315 \pm 85 v$ s. hyperinsulinemia: $1196 \pm 80 \mu \mathrm{mol} / 1, P=0.02$ ), FFA (baseline: $558 \pm 30$ vs. hyperinsulinemia: $166 \pm 16 \mu \mathrm{mol} / 1, P<0.001$ ), and glycerol (baseline: $91.6 \pm 2.7$ vs. hyperinsulinemia: $60.7 \pm 3.4 \mu \mathrm{mol} / 1, \quad P<0.001)$. No significant differences in the plasma concentrations of these metabolites were observed between ramipril and placebo treatment at baseline and during hyperinsulinemia. 


\section{Forearm blood flow}

FBF was increased after insulin stimulation (baseline: $2.1 \pm 0.2 v$ s. hyperinsulinemia: $2.5 \pm 0.1 \mathrm{ml} \cdot 100 \mathrm{ml}$ forearm tissue $\left.{ }^{-1} \cdot \mathrm{min}^{-1}, P<0.01\right)$. Baseline FBF $(P=0.14)$ and the increase in FBF after insulin stimulation $(P=0.38)$ were not significantly different after ramipril treatment compared with placebo (figure 7.4).

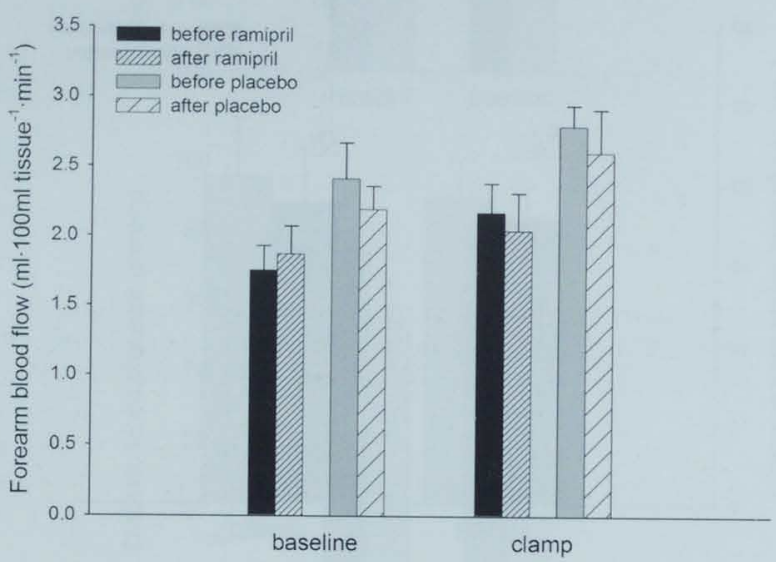

Figure 7.4 Forearm blood flow (FBF) before and after treatment. Baseline FBF ( $P=0.14$ by two-way repeated measures ANOVA) and the increase in FBF after insulin stimulation ( $P=0.38$ by two-way repeated measures ANOVA) were not significantly different after ramipril treatment compared with placebo. Values are means \pm SEM.

\section{Substrate fluxes across the forearm}

Insulin stimulation increased forearm glucose uptake (baseline: $0.28 \pm 0.06$ vs. hyperinsulinemia: $1.99 \pm 0.33 \mu \mathrm{mol} \cdot 100 \mathrm{ml}$ forearm tissue ${ }^{-1} \cdot \mathrm{min}^{-1}, P<0.001$ ) (figure 7.5) and lactate release (baseline: $-0.03 \pm 0.04$ vs. hyperinsulinemia: $-0.12 \pm 0.03$ $\mu \mathrm{mol} \cdot 100 \mathrm{ml}$ forearm tissue ${ }^{-1} \cdot \mathrm{min}^{-1}, P=0.04$ ), but had no significant effects on TAG, FFA, and glycerol fluxes across the forearm (data not shown). Ramipril treatment did not significantly affect basal and insulin-stimulated glucose uptake (figure 7.5) and other substrate fluxes (data not shown) across the forearm compared with placebo. 


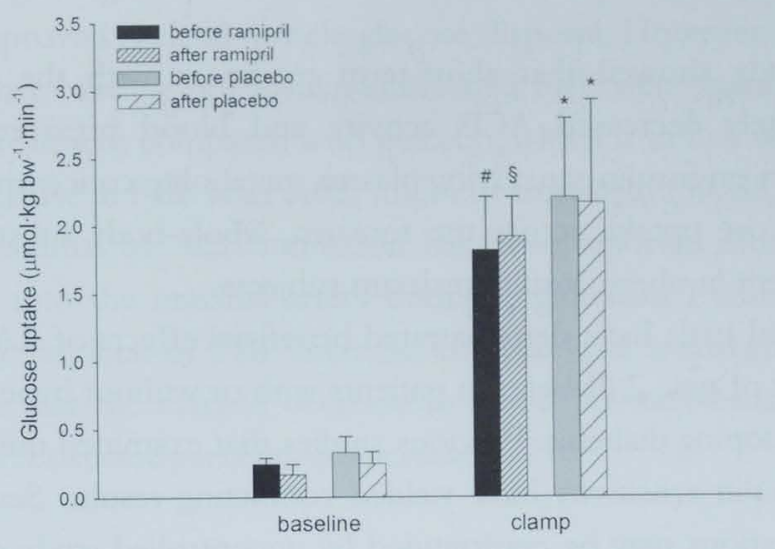

Figure 7.5 Baseline and insulin-stimulated glucose flux across the forearm before and after treatment. Insulin stimulation increased glucose uptake across the forearm $(P<0.001)$. Baseline glucose uptake across the forearm $(P=0.99$ by two-way repeated measures ANOVA) and the increase in glucose uptake across the forearm after insulin stimulation $(P=0.79$ by two-way repeated measures ANOVA) were not significantly different after ramipril treatment compared with placebo. Student's paired $t$-test, ${ }^{*} P<0.05$ vs. baseline, ${ }^{\#} P<0.01$ vs. baseline, ${ }^{\S} P<0.001$ vs. baseline. Values are means \pm SEM.

\section{Energy expenditure and whole-body substrate oxidation}

Energy expenditure was not significantly different from baseline during the hyperinsulinemic-euglycemic clamp (baseline: $5.7 \pm 0.1$ vs. hyperinsulinemia: $5.7 \pm 0.1$ $\mathrm{kJ} / \mathrm{min}, P=0.53$ ). As expected, insulin stimulation increased RQ (baseline: $0.81 \pm 0.01$ vs. hyperinsulinemia: $0.87 \pm 0.01, P<0.001)$ and carbohydrate oxidation (baseline: $0.12 \pm 0.01$ vs. hyperinsulinemia: $0.19 \pm 0.01 \mathrm{~g} / \mathrm{min}, \quad P<0.001$ ), and decreased fat oxidation (baseline: $0.07 \pm 0.00 \mathrm{vs}$. hyperinsulinemia: $0.04 \pm 0.00 \mathrm{~g} / \mathrm{min}$, $P<0.001)$. Ramipril treatment had no significant effect on basal and insulinstimulated energy expenditure, carbohydrate and fat oxidation compared with placebo.

\section{IMTG content}

IMTG content was not significantly different between the ramipril and placebo group before treatment $\left(45.4 \pm 18.8\right.$ vs. $34.7 \pm 7.5 \mu \mathrm{mol} \cdot \mathrm{mg}$ dry muscle ${ }^{-1}, P=0.60$, respectively). No significant differences in IMTG content were observed after ramipril treatment compared with placebo $(48.8 \pm 27.5$ vs. $37.1 \pm 12.2 \mu \mathrm{mol} \cdot \mathrm{mg}$ dry muscle $^{-1}, P=0.98$, respectively). 


\section{Discussion}

The present study showed that short-term treatment with the ACE inhibitor ramipril adequately decreased ACE activity and blood pressure, but had no significant effects on insulin sensitivity, plasma metabolite concentrations, forearm blood flow, glucose uptake across the forearm, whole-body substrate oxidation, and IMTG content in obese, insulin resistant subjects.

Long-term clinical trials have demonstrated beneficial effects of RAS blockade on the development of type 2 diabetes in patients with or without hypertension and at high risk of developing diabetes. Previous studies that examined the effect of ACE inhibitors on insulin sensitivity have yielded conflicting results. Several outcomes of these investigations may be confounded by uncontrolled study designs $(9,30)$, which were open $(30)$ or single-blind $(9,31)$, or based on surrogate markers of insulin sensitivity. In addition, some were comparative studies (versus other antihypertensive treatment) (7), and most if not all trials that were placebocontrolled report comparisons with baseline (before treatment) rather than direct comparisons with placebo treatment $(10,12)$, presumably because treatment groups were poorly matched at baseline. In the present study, both treatment groups were well-matched for age, BMI, waist circumference, HOMA-IR, and blood pressure after randomization. Furthermore, the present study was doubleblind and based on the hyperinsulinemic-euglycemic clamp to assess insulin sensitivity. In this well-controlled study, no significant effect of short-term ACE inhibition on insulin sensitivity was found. Despite controversial findings in previous studies, several mechanisms have been proposed that may be responsible for the potential beneficial metabolic effects of ACE inhibitors. We examined both hemodynamic and metabolic mechanisms that could play a role in this case.

\section{Forearm blood flow}

One of the most important tissues in the development of insulin resistance is skeletal muscle, as it accounts for more than $80 \%$ of insulin-stimulated glucose disposal (32). An elevated blood flow through skeletal muscle has been shown to increase glucose uptake (33), suggesting that an increase in blood flow induced by vasodilatory drugs could theoretically increase glucose uptake. In line with previous findings $(33,34)$, we observed a vasodilatory effect of insulin on skeletal muscle vasculature in the present study, which may have contributed to the increased glucose uptake across the forearm during insulin stimulation. We have previously demonstrated that local Ang II stimulation decreased skeletal muscle blood flow in 
humans (5), suggesting that ACE inhibition could evoke hemodynamic effects that may lead to improved skeletal muscle glucose disposal. However, the present data show that neither baseline nor insulin-stimulated FBF were significantly increased after ramipril treatment compared with placebo, which is in line with other reports showing no increase in FBF after ACE inhibitor treatment $(30,35,36)$. In contrast, vasodilatory potential of ACE inhibition has been reported after infusion of an $A C E$ inhibitor into the brachial artery during angiotensin I stimulation (37). An explanation for the lack of FBF increase after ramipril treatment in the present study could be that the marked decrease in blood pressure caused by a reduced total peripheral resistance prevents an increase in FBF.

\section{Insulin sensitivity, substrate fluxes across the forearm, and substrate oxidation}

A second mechanism for the reduced risk of developing diabetes after RAS blockade could be a direct stimulatory effect on glucose uptake. Animal and cell studies have demonstrated that Ang II may induce insulin resistance by direct impairment of insulin signalling $(14,15)$. This is supported by findings of improved skeletal muscle glucose disposal after ACE inhibition $(10,11,13)$, although these studies may have been confounded by the use of additional medication. In the present study, ACE inhibitor treatment had no significant effects on whole-body insulin sensitivity. In line with this, no improvements in baseline and insulinstimulated glucose uptake across the forearm were observed, indicating that ramipril treatment did not improve insulin signalling in skeletal muscle. The present data are in accordance with a recent report demonstrating that two months of treatment with the ACE inhibitor quinapril had no significant effect on glucose uptake across the forearm in type 2 diabetic patients (35). Furthermore, no significant effects of ACE inhibition on baseline and insulin-stimulated substrate oxidation were found in the present study. Therefore, it can be tentatively concluded that short-term ACE inhibitor treatment has no clinically relevant effect on insulin sensitivity.

\section{IMTG content}

Alterations in adipose tissue biology may also underlie changes in insulin sensitivity. A local Ang II generating system is present in adipose tissue (38), suggesting that Ang II can exert autocrine and paracrine effects in this tissue that may affect metabolism. It has been shown that Ang II inhibits differentiation of human preadipocytes (39). Consequently, it has been postulated that increased 
formation of Ang II by large adipocytes may inhibit adipocyte differentiation, resulting in increased storage of TAG in other tissues such as skeletal muscle, because' of a decrease in the buffering capacity for lipid storage in adipocytes, thereby causing insulin resistance (16). Therefore, blockade of the RAS may reverse insulin resistance by counteracting ectopic fat deposition. The finding that the thiazolidinedione insulin sensitizers stimulate adipocyte differentiation in rats (40), and the suggestion that failure of adipocyte differentiation may underlie the development of type 2 diabetes (41) are in line with this hypothesis. If a reduced adipocyte differentiation causes insulin resistance through IMTG accumulation, a decrease in IMTG content would precede an improvement in insulin sensitivity that may be caused by RAS blockade, tather than being a secondary effect of the improved insulin sensitivity.

In the present study, we examined whether ramipril treatment altered IMTG content, but found no significant effect of ACE inhibition on IMTG content. However, the duration of ACE inhibitor treatment in the present study may have been too short to observe a change in IMTG content. There is no data available on the time-course of changes in IMTG content evoked by drug treatment under a relatively stable life-style situation. Therefore, we cannot exclude the possibility that long-term RAS blockade decreases IMTG content, thereby improving insulin sensitivity. However, it is important to recognize that although the within-biopsy variability of the IMTG measurements was small in the present study $(<5 \%)$, it has been demonstrated before that the coefficient of variation between multiple biopsies sampled from the same leg at the same time after thorough cleaning was $24 \%$ (42). Other findings also imply that there could be high variability between small aliquots of muscle from the same biopsy, which is not due to contamination with adipocytes but appears to be-explained by differences in fiber-type composition in the obtained muscle samples from untrained subjects (43). This implies that small changes in IMTG content cannot be detected in the untrained muscle (44). Furthermore, although IMTG accumulation is an important marker of insulin resistance, recent evidence suggests that it may be lipid intermediates within skeletal muscle that causes insulin resistance, rather than IMTG itself (45).

\section{Conclusions}

This is to our knowledge the first double-blind placebo-controlled randomized trial in obese, insulin resistant subjects that examined the effects of ACE inhibitor treatment on several proposed mechanisms that may underlie the reported beneficial effects of RAS blockade on the development of diabetes. We 
demonstrated that short-term ramipril treatment has no significant effects on insulin sensitivity, glucose uptake across the forearm, whole-body substrate oxidation, IMTG content, and forearm blood flow in obese, insulin resistant subjects. Our findings are consistent with evidence from other well-designed trials in nondiabetic hypertensive patients (20) and in type 2 diabetic patients with hypertension $(17,18)$, showing no beneficial effect of short-term ACE inhibitor treatment on insulin sensitivity. Therefore, we suggest that the observed reduced incidence of diabetes after long-term RAS blockade may be caused by long-term effects of these agents that could affect insulin sensitivity, such as increased formation of adipocytes, which may counteract ectopic fat deposition in insulin sensitive tissues such as skeletal muscle.

\section{Acknowledgements}

The authors would like to thank Dr. Marco Mensink, Anneke van Hees, and Paula van der Baan for their excellent practical support, and Jos Stegen and Wendy Sluijsmans for technical assistance. This study was funded by the Wageningen Centre for Food Sciences, an alliance of major Dutch food industries, TNO Nutrition and Food Research, and Wageningen University and Research Center, with financial support from the Dutch government.

\section{References}

1. Cooper ME, Johnston CI. Optimizing treatment of hypertension in patients with diabetes. Jama 2000;283(24):3177-9.

2. Sowers JR, Epstein M, Frohlich ED. Diabetes, hypertension, and cardiovascular disease: an update. Hypertension 2001;37(4):1053-9.

3. Jandeleit-Dahm K, Cooper ME. Hypertension and diabetes. Curr Opin Nephrol Hypertens 2002;11(2):221-8.

4. Jandeleit-Dahm KA, Tikellis C, Reid CM, Johnston CI, Cooper ME. Why blockade of the renin-angiotensin system reduces the incidence of new-onset diabetes. J Hypertens 2005;23(3):463-73.

5. Goossens GH, Blaak EE, Saris WH, Van Baak MA. Angiotensin II-induced effects on adipose and skeletal muscle tissue blood flow and lipolysis in normal-weight and obese subjects. J Clin Endocrinol Metab 2004;89(6):2690-6.

6. Tikellis C, Wookey PJ, Candido R, Andrikopoulos S, Thomas MC, Cooper ME. Improved islet morphology after blockade of the renin- angiotensin system in the ZDF rat. Diabetes 2004;53(4):989-97.

7. Koh KK, Quon MJ, Han SH, Ahn JY, Jin DK, Kim HS, et al. Vascular and metabolic effects of combined therapy with ramipril and simvastatin in patients with type 2 diabetes. Hypertension 2005;45(6):1088-93.

8. Lender D, Arauz-Pacheco C, Breen L, Mora-Mora P, Ramirez LC, Raskin P. A double blind comparison of the effects of amlodipine and enalapril on insulin sensitivity in hypertensive patients. Am J Hypertens 1999;12(3):298-303. 
9. Falkner B, Canessa $M$, Anzalone D. Effect of angiotensin converting enzyme inhibitor (lisinopril) on insulin sensitivity and sodium transport in mild hypertension. Am J Hypertens 1995;8(5 Pt 1):454-60.

10. Vuorinen-Markkola $\mathrm{H}$, Yki-jarvinen $\mathrm{H}$. Antihypertensive therapy with enalapril improves glucose storage and insulin sensitivity in hypertensive patients with non-insulin-dependent diabetes mellitus. Metabolism 1995;44(1):85-9.

11. Torlone E, Rambotti AM, Perriello G, Botta G, Santeusanio F, Brunetti P, et al. ACEinhibition increases hepatic and extrahepatic sensitivity to insulin in patients with type 2 (noninsulin-dependent) diabetes mellitus and arterial hypertension. Diabetologia 1991;34(2):119-25.

12. Pollare T, Lithell $\mathrm{H}$, Berne C. A comparison of the effects of hydrochlorothiazide and captoptil on glucose and lipid metabolism in patients with hypertension. $\mathrm{N}$ Engl J Med 1989;321(13):868-73.

13. Jauch KW, Hartl W, Guenther B, Wicklmayr M, Rett K, Dietze G. Captopril enhances insulin responsiveness of forearm muscle tissue in non-insulin-dependent diabetes mellitus. Eur J Clin Invest 1987;17(5):448-54.

14. Henriksen EJ, Jacob S, Kinnick TR, Teachey MK, Krekler M. Selective angiotensin II receptor receptor antagonism reduces insulin resistance in obese Zucker rats. Hypertension 2001;38(4):884-90.

15. Folli F, Kahn CR, Hansen H, Bouchie JL, Feener EP. Angiotensin II inhibits insulin signaling in aortic smooth muscle cells at multiple levels. A potential role for serine phosphorylation in insulin/angiotensin II crosstalk. J Clin Invest 1997;100(9):2158-69.

16. Sharma AM, Janke J, Gorzelniak K, Engeli S, Luft FC. Angiotensin blockade prevents type 2 diabetes by formation of fat cells. Hypertension 2002;40(5):609-11.

17. New JP, Bilous RW, Walker M. Insulin sensitivity in hypertensive Type 2 diabetic patients after 1 and 19 days' treatment with trandolaptil. Diabet Med 2000;17(2):134-40.

18. Petrie JR, Morris AD, Ueda S, Small M, Donnelly R, Connell JM, et al. Trandolapril does not improve insulin sensitivity in patients with hypertension and type 2 diabetes: a double-blind, placebo-controlled crossover trial. J Clin Endoctinol Metab 2000;85(5):1882-9.

19. Heise T, Heinemann L, Kristahn K, Berger M, Sawicki PT. Insulin sensitivity in patients with essential hypertension: no influence of the ACE inhibitor enalapril. Horm Metab Res $1999 ; 31(7): 418-23$.

20. Wiggam MI, Hunter SJ, Atkinson AB, Ennis CN, Henty JS, Browne JN, et al. Captopril does not improve insulin action in essential hypertension: a double-blind placebo-controlled study. J Hypertens 1998;16(11):1651-7.

21. Reaven GM, Clinkingbeard C, Jeppesen J, Maheux P, Pei D, Foote J, et al. Comparison of the hemodynamic and metabolic effects of low-dose hydrochlorothiazide and lisinopril treatment in obese patients with high blood pressure. Am J Hypertens 1995;8(5 Pt 1):461-6.

22. Gress TW, Nieto FJ, Shahar E, Wofford MR, Brancati FL. Hypertension and antihypertensive therapy as risk factors for type 2 diabetes mellitus. Atherosclerosis Risk in Communities Study. N Engl J Med 2000;342(13):905-12.

23. Matthews DR, Hosker JP, Rudenski AS, Naylor BA, Treacher DF, Turner RC. Homeostasis model assessment: insulin resistance and beta-cell function from fasting plasma glucose and insulin concentrations in man. Diabetologia 1985;28(7):412-9.

24. DeFronzo RA, Tobin JD, Andres R. Glucose clamp technique: a method for quantifying insulin secretion and resistance. Am J Physiol 1979;237(3):E214-23.

25. Weir JB. New methods for calculating metabolic rate with special reference to protein metabolism. J Physiol 1949;109(1-2):1-9.

26. Frayn KN. Calculation of substrate oxidation rates in vivo from gaseous exchange. $J$ Appl Physiol 1983;55(2):628-34.

27. Webb DJ. The pharmacology of human blood vessels in vivo. J Vasc Res 1995;32(1):2-15.

28. Ferrario $\mathrm{CM}$, Brosnihan $\mathrm{KB}$, Chappell $\mathrm{M}$. Measurements of angiotensin peptides. Hypertension 1995;26(5):843-5.

29. Frayn KN, Maycock PF. Skeletal muscle triacylglycerol in the rat: methods for sampling and measurement, and studies of biological variability. J Lipid Res 1980;21(1):139-44. 
30. Santoro D, Natali A, Palombo C, Brandi LS, Piatti M, Ghione S, et al. Effects of chronic angiotensin converting enzyme inhibition on glucose tolerance and insulin sensitivity in essential hypertension. Hypertension 1992;20(2):181-91.

31. Paolisso G, Balbi V, Gambardella A, Varricchio G, Tortoriello R, Saccomanno F, et al. Lisinopril administration improves insulin action in aged patients with hypertension. J Hum Hypertens 1995;9(7):541-6.

32. DeFronzo RA, Jacot E, Jequier E, Maeder E, Wahren J, Felber JP. The effect of insulin on the disposal of intravenous glucose. Results from indirect calorimetry and hepatic and femoral venous catheterization. Diabetes 1981;30(12):1000-7.

33. Edelman SV, Laakso M, Wallace P, Brechtel G, Olefsky JM, Baron AD. Kinetics of insulinmediated and non-insulin-mediated glucose uptake in humans. Diabetes 1990;39(8):955-64.

34. Laakso M, Edelman SV, Brechtel G, Baron AD. Decreased effect of insulin to stimulate skeletal muscle blood flow in obese man. $A$ novel mechanism for insulin resistance. J Clin Invest 1990;85(6):1844-52.

35. Hermann TS, Li W, Dominguez $\mathrm{H}$, Ihlemann N, Rask-Madsen C, Major-Pedersen $A$, et al. Quinapril Treatment Increases Insulin-stimulated Endothelial liunction and Adiponectin Gene Expression in Patients with Type 2 Diabetes. J Clin Endocrinol Metab 2006;91(3):1001-8.

36. Galletti F, Strazzullo P, Capaldo B, Carretta R, Fabris F, Ferrara L $A$, et al. Controlled study of the effect of angiotensin converting enzyme inhibition versus calcium-entry blockade on insulin sensitivity in overweight hypertensive patients: Trandolapril Italian Study (TRIS). J Hypertens 1999;17(3):439-45.

37. Saris JJ, van Dijk MA, Kroon I, Schalekamp MA, Danser AH. Functional importance of angiotensin-converting enzyme-dependent in situ angiotensin II generation in the human forearm. Hypertension 2000;35(3):764-8.

38. Goossens GH, Blaak EE, van Baak MA. Possible involvement of the adipose tissue reninangiotensin system in the pathophysiology of obesity and obesity-related disorders. Obes Rev $2003 ; 4(1): 43-55$.

39. Janke J, Engeli S, Gorzelniak K, Luft FC, Sharma AM. Mature adipocytes inhibit in vitro differentiation of human preadipocytes via angiotensin type 1 receptors. Diabetes 2002;51(6):1699-707.

40. Okuno $A$, Tamemoto $H$, Tobe $K$, Ueki $K$, Mori $Y$, Iwamoto $K$, et al. Troglitazone increases the number of small adipocytes without the change of white adipose tissue mass in obese Zucker rats. J Clin Invest 1998;101(6):1354-61.

41. Danforth E, Jr. Failure of adipocyte differentiation causes type II diabetes mellitus? Nat Genet 2000;26(1):13.

42. Wendling PS, Peters SJ, Heigenhauser GJ, Spriet LL. Variability of triacylglycerol content in human skeletal muscle biopsy samples. J Appl Physiol 1996;81(3):1150-5.

43. Steffensen $\mathrm{CH}$, Roepstorff C, Madsen M, Kiens B. Myocellular triacylglycerol breakdown in females but not in males during exercise. Am J Physiol Endocrinol Metab 2002;282(3):E63442.

44. Watt MJ, Heigenhauser GJ, Spriet LL. Intramuscular triacylglycerol utilization in human skeletal muscle during exercise: is there a controversy? J Appl Physiol 2002;93(4):1185-95.

45. Hulver MW, Dohm GL. The molecular mechanism linking muscle fat accumulation to insulin resistance. Proc Nutr Soc 2004;63(2):375-80. 


\section{8}

\section{Management of obesity-related}

hypertension: reducing RAS activity

Gijs H. Goossens ${ }^{1}$, Peter W. de Leeuw ${ }^{2}$ and Marleen A. van Baak ${ }^{1}$

${ }^{1}$ Department of Human Biology, Nutrition and Toxicology Research Institute Maastricht (NUTRIM), Maastricht University, Maastricht, The Netherlands

${ }^{2}$ Department of Internal Medicine, Cardiovascular Research Institute Maastricht (CARIM), University Hospital Maastricht, Maastricht, The Netherlands.

Renin-Angiotensin System in Cardiovascular Medicine 2005;1(3):12-3 


\begin{abstract}
The role of the renin-angiotensin system (RAS) in hypertension has been welldocumented. Nowadays, there is increasingly more evidence that the RAS may also be involved in the pathophysiology of obesity and obesity-related disorders such as insulin resistance. The local RAS in adipose tissue may contribute to increased systemic RAS activity, resulting in increased blood pressure. Thus, considering the adipose tissue mass in obese individuals, the adipose tissue RAS may play an important role in obesity-related hypertension. Management of obesity-related hypertension could be achieved by combining non-pharmacological and pharmacological interventions aimed at reducing RAS activity, as discussed in this case report.
\end{abstract}




\section{Case}

A 52-year-old man was referred to our clinic by his general practitioner for further evaluation and treatment of his hypertension. He had been in good health until 6 months ago when type 2 diabetes mellitus had been diagnosed. He was initially treated with metformin to which he responded adequately. He also received a thiazide diuretic for mild hypertension $(162 / 94 \mathrm{mmHg})$.

On examination in the clinic he was well with a pulse tate of 84 beats per minute and a blood pressure of $184 / 102 \mathrm{mmHg}$. He was clearly overweight (weight $96 \mathrm{~kg}$; height $178 \mathrm{~cm}$; body mass index $30.3 \mathrm{~kg} / \mathrm{m}^{2}$ ) with a central fat distribution. Laboratory data revealed blood glucose (postprandial) $14.4 \mathrm{mmol} / \mathrm{l}$; glycosylated hemoglobin $\left(\mathrm{Hb}_{1 \mathrm{c}}\right.$ ) 8\%; serum creatinine $118 \mu \mathrm{mol} / 1$; total cholesterol 7.2 $\mathrm{mmol} / 1$; high-density lipoprotein (HDL) cholesterol $0.9 \mathrm{mmol} / \mathrm{l}$; low-density lipoprotein (LDL) cholesterol $5.1 \mathrm{mmol} / \mathrm{l}$; triglycerides $2.5 \mathrm{mmol} / \mathrm{l}$; and urinary microalbumin excretion $120 \mathrm{mg} / 24 \mathrm{~h}$.

Altogether, the patient exhibited features of the metabolic syndrome with hypertension, obesity, dyslipidemia, and type 2 diabetes mellitus. The presence of microalbuminuria suggested renal damage, probably related to the combined effects of increased blood pressure and hyperglycemia on the kidney.

Because the diabetes was not adequately controlled, treatment was intensified by administering a thiazolidine, and the patient was offered a life-style training programme. The diuretic agent was discontinued because this type of treatment may worsen diabetic control. Instead, treatment was started with an angiotensin II receptor blocker (ARB). This type of drug has shown to delay the progression of microalbuminuria to macroalbuminuria and overt diabetic nephropathy. In addition, by intertupting the activity of the RAS, $A R B$ s may help to improve obesity-related hypertension. However, often an $A R B$ as single treatment is not enough to control hypertension. At a later stage, therefore, a calcium-channel antagonist was added. After 5 months of treatment, the patient's blood pressure had decreased to $142 / 86 \mathrm{mmHg}$, and his $\mathrm{HbA}_{1 \mathrm{c}}$, had also improved $(6.8 \%)$. Although the combination of an ARB and a calcium-channel antagonist proved to be beneficial, it is conceivable that at a later stage a diuretic will need to be added to further decrease blood pressure.

Diuretics could increase RAS activity, but this has no detrimental effects because RAS activity is blocked at the same time by the ARB. With the current recommendation to set a lower blood pressure goal in a diabetic patient with 
hypertension as opposed to that in a patient with hypertension alone, this patient still needs to achieve a further decrease in blood pressure (preferably to below $130 / 80 \mathrm{mmHg}$ ).

\section{Comment}

Obesity has globally reached epidemic proportions, with more than 1 billion overweight adults (at least 300 million of them clinically obese) and is a major contributor to the global burden of chronic diseases, accounting for $2-6 \%$ of total health care costs in several developed countries (1). The true costs are undoubtedly much higher because not all obesity-related complications are included in the calculations. The increasing incidence of childhood obesity is of special concern. Importantly, obesity often causes physical impairments and psychosocial stress, which may reduce quality of life. Abdominal obesity plays a central role in the metabolic syndrome and is a major risk factor for chronic diseases, such as type 2 diabetes mellitus and cardiovascular disease.

The RAS in adipose tissue may be involved in the pathophysiology of obesity and obesity-related disorders, including hypertension and insulin resistance (2). There is substantial evidence that obesity per se is a prime cause of hypertension in obese individuals, and recent observations suggest that the adipose tissue RAS may contribute to obesity-related hypertension (3). Furthermore, it has been shown that angiotensin II (the main component of the RAS) and angiotensinogen (the precursor of angiotensin II) are involved in adipose tissue growth, differentiation, and metabolism $(2,4)$, which in the long term may promote triglycetide storage in the liver, skeletal muscle, and pancreas, thereby contributing to the development of insulin resistance (5).

Non-pharmacological interventions that reduce adipose tissue mass and blood pressure, such as moderate restriction of energy intake in combination with an increased physical activity, should be the first steps in the treatment of obesityassociated hypertension. However, long-term prevention of weight regain after weight loss is extremely difficult to achieve, which means that a large proportion of hypertensive patients may also require a pharmacological approach. With regard to the effect of beta-blockers on metabolism, the use of these drugs as first-line agents in obesity-related hypertension may be questioned. Instead, angiotensinconverting enzyme inhibitors or $\mathrm{ARBs}$ in combination with a calcium-channel antagonist, and perhaps a low-dose diuretic added at a later stage, are probably the most appropriate form of antihypertensive treatment in obese individuals. 
Prospective studies in obese patients are necessary before deciding on the most suitable antihypertensive treatment in obese individuals. Because of the central role of obesity in cardiovascular disease and hypertension, it is of great importance to prevent obesity and to control the obesity epidemic.

\section{References}

1. World Health Organization. Global strategy on diet, physical activity and health. Information sheet on obesity and overveight. Available from: www.who.int/dietphysicalactivity/publications/facts/obesity/en.

2. Goossens GH, Blaak EE, van Baak MA. Possible involvement of the adipose tissue reninangiotensin system in the pathophysiology of obesity and obesity-related disorders. Obes Rev $2003 ; 4(1): 43-55$.

3. Massiera F, Bloch-Faure M, Ceilet D, Murakami K, Fukamizu A, Gasc JM, et al. Adipose angiotensinogen is involved in adipose tissue growth and blood pressure regulation. Faseb J 2001;15(14):2727-9.

4. Goossens GH, Blaak EE, Saris WH, Van Baak MA. Angiotensin II-induced cffects on adipose and skeletal muscle tissue blood flow and lipolysis in normal-weight and obese subjects. J Clin Endocrinol Metab 2004;89(6):2690-6.

5. Sharma AM, Janke J, Gorzelniak K, Engeli S, Luft FC. Angiotensin blockade prevents type 2 diabetes by formation of fat cells. Hypertension 2002;40(5):609-11. 


$$
!
$$


General discussion 
Abdominal obesity plays a central role in the metabolic syndrome and is a major risk factor for type 2 diabetes mellitus and cardiovascular disease (1). Unravelling the underlying mechanisms of obesity and obesity-related disorders, such as insulin resistance and hypertension, may increase the rationale for dietary and/or pharmacological strategies to prevent or treat type 2 diabetes and cardiovascular disease.

As discussed in chapter 1, disturbances in adipose tissue and skeletal muscle metabolism may, together with hemodynamic alterations in these tissues, underlie the development of insulin resistance and type 2 diabetes. Additionally, since the recognition of adipose tissue as an endocrine organ, there has been great interest in the possibility that an adipose tissue-derived factor may contribute to the cluster of metabolic and hemodynamic disturbances often observed in obesity. The studies described in this thesis focussed on the possible involvement of the reninangiotensin system (RAS) in obesity-related disorders, as reviewed in chapter 2. We examined both local (autocrine/paracrine) metabolic and hemodynamic effects of the RAS in adipose tissue and skeletal muscle and systemic (endocrine) effects of RAS blockade in normal-weight and obese subjects, combining state-of-the-art in vivo techniques and in vitro approaches. In this chapter, the results we have obtained will be discussed and put into a broader perspective. Furthermore, the clinical relevance of our findings will be highlighted, and important issues for future research will be addressed.

\section{RAS activity in obesity}

There is substantial evidence that circulating RAS components are increased in obesity (2-8). In addition, it has recently been demonstrated that weight loss reduces systemic RAS activity in humans (2). These observations indicate that obesity is responsible for increased systemic RAS activity. Furthermore, because adipose tissue is an endocrine organ (9) and RAS components are expressed in human adipose tissue $(2,10-12)$, this suggests that RAS components that are expressed in adipose tissue may also be secreted into the circulation. Thus, it is tempting to speculate that the adipose tissue RAS may exert both autocrine/paracrine and endocrine effects. This concept is supported by a study where wild-type (WT) mice were compared with AGT knock-out mice (AGT-/), and with transgenic mice specifically (over)expressing AGT in adipose tissue either on the AGT $\%$ background or on the WT background. This comparison showed that adipocytes are a considerable source of plasma AGT. Furthermore, the 
transgenic mice had an elevated blood pressure compared with their AGTcontrols (13), supporting an important role for the adipose tissue RAS in hypertension. If RAS components are indeed secreted from adipose tissue into the circulation in humans, excess adipose tissue mass may increase systemic RAS activity, thereby magnifying RAS effects on the vasculature and in other tissues. Several components of the RAS are also present in other tissues than adipose tissue (14-21), including skeletal muscle (22), implying that these tissues also have the ability to produce Ang II.

In chapter 3, we demonstrated that there was no significant net Ang II release across abdominal subcutaneous adipose tissue and the forearm under baseline conditions. Thus, Ang II that is produced by adipocytes (23) and in skeletal muscle $(22,24,25)$ appears to act as an autocrine/paracrine hormone, but does not reach the systemic circulation. This is in line with the finding that circulating Ang II concentrations are comparable in lean and obese subjects (2), and with our findings in chapter 5, suggesting that locally produced Ang II in adipose tissue does not reach the vasculature. So far, only one recent study assessed Ang II secretion from adipose tissue in vivo, and concluded that Ang II concentrations were increased in venous blood draining abdominal subcutaneous adipose tissue compared with arterial blood in overweight/obese subjects (26). However, in this study supraphysiological Ang II concentrations were reported, suggesting that the strict methodological procedures to be followed when performing Ang II measurements $(27,28)$ were not taken into account. Therefore, the validity of these findings may be questioned. Our observation that Ang II is not released from the forearm under baseline conditions is line with previous findings in hypertensive patients (25).

In contrast to circulating Ang II concentrations, other RAS components, such as AGT and renin, are elevated in obese subjects (2-8), suggesting that the obese state is responsible for increased systemic RAS activity. It is intriguing to speculate that AGT and renin are released from adipose tissue in obese subjects and may contribute to circulating Ang II concentration. We are currently investigating whether other RAS components that are present in adipose tissue and skeletal muscle play an endocrine role in humans.

It is important to realise that we have studied release of RAS components from abdominal subcutaneous adipose tissue. As has been shown for other adipokines, AGT mRNA expression is higher in visceral compared with subcutaneous adipose tissue $(29,30)$. The obese subjects that were examined in our study were abdominally obese, indicated by a high waist circumference and high waist-to-hip 
ratio, suggesting the presence of abundant visceral fat. However, visceral fat constitutes about $10 \%$ of total body fat mass in lean and obese men (31), and it has been demonstrated that only a very small part of the fatty acids that enter the systemic circulation are derived from visceral adipose tissue (32). The same may also apply to several adipokines released from this fat depot. Furthermore, it is important to recognize that subcutaneous adipose tissue represents about $75 \%$ of total body fat mass. Expression of genes encoding secreted proteins in subcutaneous adipose tissue is therefore likely to have substantial impact on circulating concentrations. Therefore, it seems reasonable to assume that if there is Ang II release from the visceral fat depot, this does not substantially contribute to plasma Ang II concentration. However, this does not exclude the possibility that locally produced Ang II in visceral adipose tissue may exert autocrine and/or paracrine effects, or effects on the liver.

Finally, our studies on the release of Ang II from adipose tissue and the forearm were performed in normotensive subjects. Therefore, we cannot fully exclude the possibility that there is Ang II release from adipose tissue in other subject groups, such as obese hypertensive patients, which may contribute to obesity-related hypertension.

\section{$\beta$-Adrenergic stimulation and $\mathrm{R} A S$ activity}

We also examined the effect of $\beta$-adrenergic stimulation on systemic RAS activity and net Ang II fluxes across abdominal subcutaneous adipose tissue and the forearm. In chapter 3 , we demonstrated that $\beta$-adrenergic stimulation increases plasma Ang II concentrations in obese, but not in lean subjects. This observation is in agreement with reports suggesting that the $\beta$-adrenergic system increases renin release (33-37), renin activity (38), and Ang II release from isolated mesenteric arteries (39), and thus seems to be involved in the regulation of the RAS. Similar to our findings under baseline conditions, we were not able to detect significant net Ang II release from adipose tissue and the forearm during $\beta$-adrenergic stimulation. The absence of detectable Ang II release from the forearm during $\beta$ adrenergic stimulation appears to be in contradiction with previous reports, showing that local $\beta$-adrenergic stimulation releases renin and angiotensin II from forearm vessels in subjects with essential hypertension $(24,25)$. However, several explanations may be responsible for this apparent discrepancy. It is likely that the subjects that participated in our study had lower renin concentrations, as they were normotensive and maintained their normal dietary sodium intake, in contrast to the sodium-depleted hypertensive patients that were studied by Taddei and co-workers 
$(24,25)$. The finding that Ang II release from the forearm was closely correlated with circulating renin concentrations (25) suggests that Ang II production in skeletal muscle is at least partly dependent on uptake of renin from the circulation and may explain the present observations. Secondly, the more pronounced increase in forearm blood flow after intrabrachial infusion of isoprenaline (25) compared with that induced by systemic $\beta$-adrenergic stimulation in our study suggests that the $\beta$-adrenergic stimulus was higher during local administration. Finally, as it has been shown that the release of renin and Ang II actoss the forearm during local $\beta$-adrenergic stimulation rapidly declines after 5-10 min (25), we may not have been able to detect significant Ang II release from the forearm in our experimental set-up.

Our findings imply that the observed increase in plasma Ang II concentrations during $\beta$-adrenergic stimulation in obese subjects is explained by other factors than Ang II release from abdominal subcutaneous adipose tissue and/or the forearm. Release of AGT from adipose tissue and subsequent conversion to Ang II in the circulation or, alternatively, local Ang II secretion from other tissues than adipose tissue and the forearm, such as the kidney and liver, may explain this observation. The increased Ang II concentrations after $\beta$-adrenergic stimulation in obese subjects may amplify several endocrine effects of Ang II, including effects on tissue blood flow, as will be discussed in the next section.

\section{RAS and tissue blood flow}

Tissue-specific regulation of blood flow in tissues such as skeletal muscle, liver, and adipose tissue is necessary to meet the local metabolic and physiological demands under varying conditions. This section describes the importance of blood flow through adipose tissue and skeletal muscle, and discusses our findings on the involvement of Ang II in the regulation of these events.

\section{Adipose tissue blood flow}

In lean, healthy individuals, ATBF is responsive to nutrient intake. Carbohydrate ingestion is a greater stimulus to increase ATBF than fat intake (40-42). The ATBF response to nutrient intake may be of great importance in the regulation of wholebody substrate metabolism (43). However, ATBF regulation is not uniform in all people. Both fasting ATBF (44-46) and ATBF responsiveness to nutrients $(44,45)$ are blunted in obesity, and this impairment is clearly associated with insulin resistance $(44,47)$. The importance of adequate blood flow regulation is further 
stressed by the fact that the extraction of TAG in adipose tissue is increased when ATBF is increased pharmacologically (48). In line with this, a blunted ATBF is associated with risk factors for cardiovascular disease, such as increased blood pressure and insulin resistance $(44,47)$. Thus, disturbances in ATBF regulation may underlie many aspects of insulin resistance and the accompanying cardiovascular risk.

Over the last couples of years, it has become clear that fasting ATBF is strongly determined by nitric oxide (NO) and is to some extent under $\alpha$-adrenergic control, while the postprandial enhancement of ATBF is mainly determined by $\beta$-adrenergic stimulation (49). Although considerable progress has been made in elucidating the physiological basis for ATBF regulation, some issues are still unanswered.

\section{Fasting adipose tissue blood flow regulation}

It is well-established that Ang II exerts vasoconstrictive effects in the systemic circulation and is an important regulator of blood pressure and fluid homeostasis (50). Therefore, we hypothesized that Ang II would also cause vasoconstriction in adipose tissue, and may be involved in the lower fasting ATBF observed in obese compared with lean subjects (44-46). We first performed a study to examine the effects of Ang II on fasting ATBF in normal-weight and obese subjects using the microdialysis technique, which offers the possibility to locally administer certain agents, while avoiding systemic effects (chapter 4). Local Ang II stimulation decreased fasting ATBF to a similar extent in normal-weight and obese subjects. Although the ethanol outflow/inflow ratio, which was used as an indicator of local blood flow, provides a qualitative estimate of tissue blood flow, the magnitude of the observed responses suggested that Ang II may exert potent vasoconstrictive effects in this tissue.

Based on these findings, we decided to investigate the role of Ang II in ATBF regulation into more detail using the recently developed microinfusion technique, as discussed in chapter 5. Briefly, the ${ }^{133 \mathrm{Xe}}$ wash-out technique, which is considered as the golden standard for measurement of ATBF (51), was used to determine ATBF. The microinfusion technique allows semi-quarititative assessment of the local effects of vasoactive compounds on ATBF by introducing

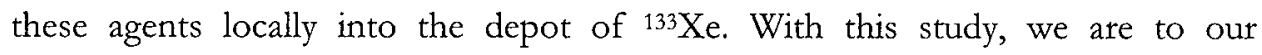
knowledge the first to dissect the relative contribution of locally produced Ang II in adipose tissue and circulating Ang II to an Ang II-induced effect in this tissue, in this case the effect on ATBF. 
Firstly, we found that microinfusion of Ang II into abdominal subcutaneous adipose tissue evoked marked vasoconstrictive effects, which is in line with the microdialysis findings described in chapter 4 . The magnitude of the observed effect suggests that Ang II is a major regulator of fasting ATBF in humans. Secondly, it appeared from the ACE inhibition and $A T_{1}$ receptor blockade experiments that circulating Ang II, rather than Ang II that is locally produced in adipose tissue, decreases fasting ATBF under physiological conditions. Because Ang II is produced by the adipocyte (23), these data suggest that locally produced Ang II in adipose tissue acts as a paracrine hormone that does not reach the endothelium to induce vasoconstriction, which is in accordance with our findings in chapter 3. Thirdly, we showed that NO plays an important role in fasting ATBF, as has previously been demonstrated (49). Furthermore, the Ang IIinduced decrease in ATBF was predominantly independent of $\mathrm{NO}$ action. Therefore, the present data suggest that the balance between Ang II and NO stimulation may be an important determinant of the vascular tone and thus ATBF under fasting conditions. The balance between effects of vasoconstrictors and vasodilators is extremely important in long-term vascular function. Endothelial dysfunction is defined as an imbalance in which the effects of vasoconstrictors outweigh the effects of vasodilators. This imbalance generally results from decreased NO bioactivity, which is measured as decreased vasodilatory capacity. However, this also implies loss of vascular protection, as NO has multiple vascular-protective effects, including inhibition of vascular smooth muscle cell growth and migration, platelet aggregation and thrombosis, monocyte adhesion, inflammation, and oxidation (52). Reduced NO-dependent vasodilatation may be intrinsic to the insulin resistance syndrome, and may therefore be a marker of metabolic health (53). Although our data indicated that there is no acute interaction between Ang II and NO in ATBF regulation, there is strong evidence that Ang II plays a crucial role in the development of endothelial dysfunction by promoting vascular damage and inflammation, and reducing NO activity $(52,54)$.

Based on our findings, we cannot give a definite answer to the question whether Ang II is responsible for the reported lower fasting ATBF in obese compared with lean subjects $(45,46,55,56)$. Since systemic RAS activity is increased in obesity (28 ), this may well be the case. Because we have performed the experiments described in chapter 5 in lean subjects, we cannot fully exclude the possibility that locally produced Ang II contributes to the decreased ATBF in obese (insulin resistant) subjects. The observation that weight loss reduces systemic RAS activity and AGT mRNA expression in adipose tissue in obese women (2) supports the 
idea that reduced RAS activity may explain the increased basal adipose tissue blood flow observed after weight reduction (46). Taken together, although further studies are needed, these data provide indirect evidence to suggest that the RAS may contribute to the decreased ATBF in obese individuals.

\section{Postprandial adipose tissue blood flow regulation}

Our findings in chapter 5 further indicate that Ang II does not appear to have great impact on the postprandial enhancement of ATBF in lean subjects, which is in accordance with previous investigations showing that postprandial ATBF is predominantly controlled by the $\beta$-adrenergic system $(49,57)$. However, because Ang II decreases the absolute level of fasting ATBF, this may result in a reduced absolute ATBF after a meal in conditions where systemic RAS activity is increased, such as obesity. As mentioned before, a blunted postprandial enhancement of ATBF could have pathophysiological implications in that postprandial hyperlipidemia and related metabolic complications may occur $(44,47,48)$, which are well-known cardiovascular risk factors.

\section{Skeletal muscle blood flow}

Skeletal muscle is one of the most important tissues in the development of insulin resistance, as it accounts for more than $80 \%$ of insulin-stimulated glucose disposal (58). The vascular system controls the delivery of nutrients and hormones to muscle, and a number of hormones may act to regulate muscle metabolism and contractile performance by modulating blood flow to and within muscle.

It has been reported that the insulin-mediated increase in muscle perfusion accounts for approximately $30 \%$ of the overall effect of insulin to stimulate glucose uptake in skeletal muscle, suggesting a role for insulin and glucose delivery as determinants of insulin action (59). However, controversial data have been reported on the impact of insulin on skeletal muscle blood flow, as well as on the impact of skeletal muscle blood flow on glucose uptake in muscle. More recent work suggests that the redistribution of blood flow from non-nutritive to nutritive vessels, rather than total blood flow through skeletal muscle, may be an important factor that determines skeletal muscle glucose uptake (60). There is accumulating evidence to suggest that insulin resistance of muscle in vivo in terms of impaired glucose uptake could be partly due to impaired insulin-mediated capillary recruitment (61). It has recently been demonstrated that microvascular function is impaired in obesity and this was associated with increased blood pressure and 
decreased insulin sensitivity (62). Consequently, pathophysiological states associated with maldistribution or lack of enhancement of blood flow in response to insulin may be associated with insulin resistance, as has also been demonstrated in obese Zucker rats (63). Likewise, one can speculate that any endogenous agent that affects flow (distribution) in skeletal muscle may affect glucose uptake. Therefore, a better understanding of the regulation of skeletal muscle blood flow is needed.

As discussed in chapter 4, we found that Ang II decreased skeletal muscle blood flow in normal-weight and obese subjects. Although one may argue that the Ang II-induced decrease in skeletal muscle blood flow would decrease the delivery of glucose and insulin to the tissue, thereby reducing glucose uptake, this remains to be established. Firstly, the effect of Ang II on skeletal muscle blood flow should be regarded as qualitative or semi-quantitative, as exact tissue concentrations of Ang II during local Ang II administration are unknown. Therefore, we cannot draw firm conclusions about the magnitude of the effects of Ang II on tissue blood flow. Secondly, as discussed above, the impact of the Ang II-induced vasoconstriction in skeletal muscle vasculature on glucose uptake needs to be appraised within the context of vessel recruitment. Unfortunately, it is currently not possible to discriminate between nutritive and non-nutritive blood flow in humans, and Ang II effects on total tissue blood flow cannot be extrapolated to effects on nutritive blood flow. In other words, if Ang II reduces the recruitment of nutritive vessels within skeletal muscle, this may evoke a decrease in skeletal muscle glucose uptake and contribute to insulin resistance in this tissue in situations where RAS activity or Ang II sensitivity for vasoconstriction is increased. In conclusion, Ang II appears to play an important tole in skeletal muscle blood flow, but future research is needed to establish the importance of vascular effects of Ang II in skeletal muscle on glucose uptake in this tissue.

\section{RAS and lipid metabolism}

When energy intake exceeds energy expenditure, the energy surplus is stored mainly in adipose tissue in the form of triglycerides (TAG). Whole-body energy balance therefore regulates the amount of TAG stored in adipocytes, which in turn reflects the net balance between fat deposition and fat mobilization. Alterations in this balance may contribute to the pathophysiology of obesity and insulin resistance. More specific, increased storage and reduced mobilization of fatty acids may result in the expansion of fat mass, which is strongly associated with the 
development of insulin resistance and type 2 diabetes, as discussed in chapter 1. Evidence from animal models suggests that the RAS is involved in diet-induced weight gain (64). In line with this, mice with a tissue-specific overexpression of AGT in adipose tissue had an increased body weight and fat mass compared with the non-transgenic mice (13), which may be explained by Ang II action on lipid synthesis and storage in adipocytes (65). Furthermore, decreased adipose tissue lipolysis (reduced mobilization of lipids from adipose tissue) may also contribute to the enlargement of adipose tissue.

Reports on the effects of Ang II on lipolysis in human adipose tissue in vivo have yielded conflicting results. Both inhibitory $(66,67)$ and stimulatory $(68)$ effects of Ang II on lipolysis in adipose tissue in normal-weight subjects have been reported by the same research group. Furthermore, no effect of Ang II on lipolysis was observed in obese subjects (68), but an explanation for these controversial findings is lacking. In human skeletal muscle, inhibition of lipolysis by Ang II has been demonstrated (68). These puzzling data may be confounded by methodological issues. The ethanol outflow/inflow ratios, used as indicators of tissue blood flow, were remarkably low in the above mentioned studies. This hampers interpretation of Ang II effects on lipolysis and questions the validity of these data. We decided to further investigate the effects of Ang II on lipolysis.

In chapter 4, we showed that Ang II decreases lipolysis both in adipose tissue and skeletal muscle in vivo in normal-weight and obese subjects, with no differences between groups. In contrast to previous studies that examined the effects of Ang II on lipolysis, we used control probes to take into account changes in tissue blood flow and lipolysis that were not due to the intervention, and both groups of subjects were well-matched for age. Furthermore, a wash-out period between each perfusion step was included in our design to prevent any carry-over effects of agents that were administered in a previous perfusion step that could affect the next infusion period. The antilipolytic effect of Ang II in adipose tissue was seen at the lowest (physiological) dose used, but inhibition of lipolysis was less clear at a supraphysiological dose. To obtain better insight into the dose-response effect of Ang II, and to assess whether the inhibition of lipolysis was caused by direct effects of Ang II on the adipocyte, in vitro lipolysis experiments were initiated.

In chapter 6, we demonstrated that Ang II inhibits lipolysis in isolated human abdominal subcutaneous adipocytes. Ang II decreased lipolysis to the same extent $(\sim 20 \%)$ in normal-weight and obese subjects (Study 1). However, no clear doseresponse effect could be observed in these experiments, as near-maximal inhibition of lipolysis was already achieved at the lowest dose used. To further substantiate 
and elaborate these preliminary observations, an additional group of obese subjects was studied (Study 2). Using lower doses of Ang II in the second study, a dosedependent reduction of lipolysis by Ang II could be demonstrated, with a maximal inhibition of basal lipolysis of $\sim 20-25 \%$. The magnitude of the observed antilipolytic effects was comparable with that in Study 1. Importantly, the effects of Ang II on lipolysis were completely abolished by $\mathrm{AT}_{1}$ receptor blockade, clearly indicating that the Ang II-induced inhibition of lipolysis is mediated through the $\mathrm{AT}_{1}$ receptor.

Taken together, both in vino (chapter 4) and in vitro (chapter 6) findings suggest that Ang II inhibits lipolysis in adipose tissue. Because stimulation of adipocytes with concentrations comparable with circulating Ang II concentrations ( 10 pM) evoked near-maximal inhibition of lipolysis, Ang II may exert a tonic suppression of lipolysis in vivo in humans. Furthermore, the antilipolytic effect seems to be less pronounced compared with that of insulin $(69,70)$, suggesting that Ang II does not play a prominent role in the regulation of fat cell lipolysis. These findings, together with the reported inhibitory effect of Ang II on adipocyte differentiation in humans (71), delineate that Ang II may not be involved in the expansion of fat mass in humans. The Ang II-induced inhibition of lipolysis in skeletal muscle may contribute to an increased IMTG content. However, further research is needed to examine the dose-response effect of Ang II on skeletal muscle lipolysis.

The relevance of the antilipolytic effects of Ang II in adipose tissue and skeletal muscle in human physiology warrants further investigation. Although increased RAS activity may not play an important role in the development of obesity, it may be of importance in the (re)distribution of lipids from adipose tissue to other organs, such as skeletal muscle and the liver, as will be discussed in the next section.

\section{ACE inhibition and insulin sensitivity}

Long-term clinical trials have suggested that blockade of the RAS, either by ACE inhibition (72-74) (reducing Ang II production) or by blocking the Ang II type 1 $\left(A T_{1}\right)$ receptor (75) (blocking Ang II action) may be protective against the development of type 2 diabetes mellitus (76). These observations have led to discussion about the underlying mechanisms for these findings. The protective effect of reducing RAS activity against the development of diabetes has been explained by effects on skeletal muscle, the pancreas, and adipose tissue. Previous studies that examined the effect of ACE inhibitors on insulin sensitivity have 
yielded conflicting results. Several outcomes of these investigations may have been confounded by methodological issues, such as uncontrolled study designs, the use of surrogate markers of insulin sensitivity, and potential confounding by the use of medication in addition to the study medication.

As described in chapter 7 , we performed a double-blind placebo-controlled randomized trial in obese, insulin resistant subjects to examine the effects of shortterm ACE inhibitor treatment on several proposed mechanisms that may underlie the reported beneficial effects of RAS blockade on the development of diabetes. We demonstrated that 2-week treatment with the ACE inhibitor ramipril has no significant effects on whole-body insulin sensitivity, forearm blood flow, glucose uptake across the forearm, whole-body substrate oxidation, and IMTG content. Our findings are consistent with evidence from other well-designed trials in nondiabetic hypertensive patients (77) and in type 2 diabetic patients with hypertension $(78,79)$, showing no beneficial effect of short-term ACE inhibitor treatment on insulin sensitivity.

In chapter 4, we demonstrated that local Ang II stimulation decreased skeletal muscle blood flow in humans (80), suggesting that ACE inhibition may evoke an increase in skeletal muscle blood flow. As discussed in a previous section of this chapter, changes in muscle blood flow may affect glucose uptake in this tissue. However, chapter 7 showed that forearm blood flow was not significantly increased after ACE inhibitor treatment, which is in line with other reports showing no change in skeletal muscle blood flow after ACE inhibitor treatment (81-83). An explanation for the lack of effect on muscle blood flow could be that the decrease in blood pressure caused by a reduced total peripheral resistance prevents an increase in total blood flow through skeletal muscle. Alternatively, although the dose of ramipril was sufficient to substantially lower blood pressure, it may not have been high enough to reduce ACE activity in skeletal muscle. Furthermore, in line with unchanged whole-body insulin sensitivity, we did not observe an increase in basal and insulin-stimulated glucose uptake in skeletal muscle, suggesting that short-term ACE inhibition does not improve skeletal muscle glucose metabolism. In accordance with these findings, whole-body substrate oxidation was not affected by short-term ACE inhibitor treatment.

Another mechanism that has been proposed to explain the reduced incidence of type 2 diabetes after RAS blockade is an increased blood flow through the pancreas, which may increase insulin secretion. We did neither observe an increase in fasting insulin concentrations after ACE inhibitor treatment, nor an increase in insulin secretion by the $\beta$-cell (estimated by homeostasis model assessment for 
$\beta$-cell function (84)), suggesting that insulin secretion by the pancreas was not elevated after short-term ramipril treatment. However, because we did not measure $\beta$-cell function directly, no firm conclusions can be drawn concerning the effects of ACE inhibition on $\beta$-cell function.

What could then be the explanation for the observed reduced incidence of diabetes after long-term RAS blockade? It has been shown that Ang II inhibits differentiation of human preadipocytes to mature adipocytes (71). This observation has led to the hypothesis that an Ang II-induced reduction of adipocyte differentiation may decrease the buffering capacity for lipid storage in adipose tissue, which may result in ectopic fat storage, thereby causing insulin resistance (85). The inhibition of fat cell lipolysis by Ang II, as demonstrated in chapters 4 and 6, and the previously reported lipogenic effects of Ang II in adipose tissue (65) may further contribute to a reduced buffering capacity for lipid storage in adipose tissue. Thus, Ang II may increase lipid storage in adipocytes in the shortterm, possibly contributing to the development of hypertrophic adipocytes in obesity. In the long-term, these processes may further reduce the buffering capacity for lipid storage in adipose tissue, which may consequently result in an excessive influx of TAG and fatty acids to skeletal muscle (86-88), the pancreas (89), and liver $(90,91)$, leading to insulin resistance. The Ang II-induced decrease in ATBF may further contribute to an increased delivery of TAG and fatty acids to these tissues (48). In addition, the Ang II-induced inhibition of lipolysis in skeletal muscle, as found in chapter 4, may further contribute to an increased IMTG content, but the physiological importance of this finding remains to be elucidated. Therefore, similar to the working mechanism of the thiazolidinedione (TZD) insulin sensitizers, it has been hypothesized that blockade of the RAS may reverse insulin resistance by counteracting ectopic fat deposition (85). If a reduced adipocyte differentiation causes insulin resistance through IMTG accumulation, a decrease in IMTG content after RAS blockade would precede an improvement in insulin sensitivity rather than being a secondary effect of the improved insulin sensitivity. However, in chapter 7, we found no significant effect of ACE inhibition on IMTG content. The duration of ACE inhibitor treatment in this study may have been too short to induce structural changes in adipose tissue and to observe a change in IMTG content. There are no data available on the timecourse of changes in IMTG content evoked by drug treatment under relatively stable life-style conditions. Therefore, we cannot exclude the possibility that longterm RAS blockade may decrease IMTG content, thereby improving insulin sensitivity. 
Finally, it is known that obesity and type 2 diabetes are associated with a state of chronic low-grade inflammation. Over the last decade, abundant evidence has emerged demonstrating a close link between metabolism and immunity. The state of chronic inflammation typical of obesity and type 2 diabetes occurs at metabolically relevant sites, such as the liver, skeletal muscle, and adipose tissue (92-94). While this relationship has also been recognized in the clinical setting, its molecular basis and physiological significance are not yet fully understood. Two mechanisms that may be relevant in the initiation of inflammation in obesity are endoplasmic reticulum (ER) stress and oxidative stress, as reviewed recently (92). There is evidence that Ang II is involved in inflammation and oxidative stress (95, 96), and blockade of the RAS may reverse these events $(97,98)$. Thus, it is tempting to speculate that reduction of the inflammatory response and oxidative stress may be important mechanisms by which long-term RAS blockade reduces the development of diabetes. This is an interesting topic for future research.

In summary, we could not demonstrate beneficial effects of short-term ACE inhibition on whole-body insulin sensitivity, forearm blood flow, glucose uptake across the forearm, whole-body substrate oxidation, and IMTG content in obese, insulin resistant subjects. Therefore, it can be tentatively concluded that short-term RAS blockade has no clinically relevant effects on insulin sensitivity. Our findings are consistent with evidence from other well-designed trials in nondiabetic hypertensive patients (77) and in type 2 diabetic patients with hypertension (78, 79), showing no beneficial effect of short-term ACE inhibitor treatment on insulin sensitivity. Therefore, we suggest that the observed reduced incidence of type 2 diabetes after long-term RAS blockade is caused by long-term effects of these agents that could affect insulin sensitivity, such as increased formation of adipocytes or reduced oxidative stress and inflammation. There is an obvious need for clinical trials specifically designed to assess the protective benefits of blocking the RAS in individuals at risk of developing type 2 diabetes. Two large multi-centre double-blind randomized trials on the prevention of type 2 diabetes are ongoing, the Diabetes Reduction Assessment with Ramipril and Rosiglitazone Medications (DREAM) study and the Nateglinide and Valsartan in Impaired Glucose Tolerance Outcomes Research (NAVIGATOR) trial, which is also designed to assess cardiovascular events (76). 


\section{Obesity-related hypertension}

The pathophysiology of hypertension stems from the inability of the kidney to excrete sodium at a normal pressure. However, the central nervous system, the large arteries, the microcirculation, and endocrine factors also play a role in this disorder. It is widely believed that essential hypertension is a multifactorial disorder caused by heterogeneous genetic and environmental factors. Hypertension aggregates with other cardiovascular risk factors, such as abdominal obesity, dyslipidemia, glucose intolerance, and hyperinsulinemia, possibly because of a common underlying cause (99). Although abdominal obesity is frequently accompanied by hypertension, the mechanisms by which an excess fat mass may lead to hypertension are not fully understood.

The RAS has been established as a major regulator of blood pressure and fluid homeostasis $(15,50,100-104)$. Although the RAS may play an important role in obesity-related hypertension, the notion that interference with a sole pathophysiological mechanism will substantially facilitate prevention or treatment of hypertension is an oversimplification that ignores the heterogeneous nature of this disorder. Chapter 8 clearly shows that the treatment of obesity-related hypertension is ambiguous, and highlights the role of RAS blockade in the treatment of hypertension in obese individuals. An integrated approach of genetic, molecular, clinical, and epidemiological research may identify patient groups in whom specific combinations of genetic and environmental factors increase blood pressure, and could provide information for a more efficient treatment of hypertension. Prospective studies in obese parients are necessary before deciding on the most suitable antihypertensive treatment in these individuals.

\section{Perspectives and future directions}

The series of studies that are described in this thesis provide better insight into both local (autocrine/paracrine) metabolic and hemodynamic effects of the RAS in adipose tissue and skeletal muscle and systemic (endocrine) effects of RAS blockade. We demonstrated that:

1. locally produced Ang II in adipose tissue and skeletal muscle does not play an endocrine role in lean and obese subjects, indicating that Ang II that is locally produced in these tissues exerts autocrine/paracrine effects. Importantly, this does not exclude an important role for the RAS in obesity-related hypertension and insulin resistance, as systemic RAS activity is increased in 
obesity (2-8). Furthermore, local effects of Ang II in adipose tissue may contribute to the development of insulin resistance.

2. Ang II inhibitis lipolysis in adipose tissue and skeletal muscle. However, our data suggest that a physiological Ang II concentration exerts a tonic suppression of lipolysis in human adipocytes. Therefore, Ang II may not play a prominent role in the regulation of fat cell lipolysis in vivo in humans. These findings, in combination with the reported inhibitory effect of Ang II on adipocyte differentiation in humans (71), suggest that Ang II is not an important factor in the expansion of fat mass in humans. Instead, Ang II may reduce the buffering capacity for lipid storage in adipose tissue, leading to an excessive influx of fatty acids and TAG to skeletal muscle, liver, and pancreas, thereby inducing insulin resistance. The Ang II-induced inhibition of lipolysis in skeletal muscle may also contribute to lipid accumulation in this tissue. However, further research is needed to examine the dose-response effect of Ang II on lipolysis in skeletal muscle.

3. Ang II is a major regulator of fasting adipose tissue and skeletal muscle blood flow. Ang II appears to have no major effect on the postprandial enhancement of adipose tissue blood flow. The Ang II-induced decrease of blood flow through adipose tissue and skeletal muscle may have great impact on metabolism, as blood flow determines the delivery of substrates and hormones to each tissue. A decreased ATBF may lead to reduced TAG clearance by adipose tissue (48), resulting in an increased delivery of TAG to skeletal muscle, liver and pancreas. The decrease in skeletal muscle blood flow evoked by Ang II may affect glucose uptake in this tissue.

4. short-term RAS blockade has no significant effects on insulin sensitivity, forearm blood flow, glucose uptake in skeletal muscle, whole-body substrate oxidation, and IMTG content in obese, insulin resistant subjects. Therefore, the reduced incidence of type 2 diabetes after long-term RAS blockade appears to be explained by long-term effects of these agents that could affect insulin sensitivity, such as increased formation of adipocytes or reduced oxidative stress and inflammation.

Based on our current knowledge of the RAS, dietary and/or pharmacological strategies to interfere with the RAS may, in addition to life-style modifications, be considered as a valuable approach to prevent or treat obesity-related hypertension and insulin resistance. However, several issues with regard to the (patho)physiological role of the RAS in obesity-related disorders remain to be 
answered, as well as important topics with regard to the implications of disturbances in adipose tissue and skeletal muscle blood flow. Some important questions that need to be addressed in further research include the following:

- What is the contribution of adipose tissue and skeletal muscle to circulating RAS components, such as AGT and renin, in obese (hypertensive) subjects? Is the release of these RAS components increased in obese compared with lean subjects?

- What are the underlying mechanisms for the beneficial long-term effects of RAS blockade on the development of insulin sensitivity? Are there structural changes in adipose tissue (e.g. reduced adipocyte size) after long-term RAS blockade and are these linked with a decreased IMTG content or a reduced concentration of lipid intermediates in skeletal muscle? Does RAS blockade induce a decrease in inflammation and oxidative stress, and is this associated with improved insulin sensitivity? Are there changes in content or activity of important enzymes of $\beta$-oxidation, the TCA-cycle, and electron transport in skeletal muscle that may underlie the reduced incidence of type 2 diabetes after RAS blockade?

- Does Ang II contribute to disturbances in adipose tissue blood flow observed in (obese) insulin resistant subjects?

- Do disturbances in ATBF play a (primary) role in the development of insulin resistance?

- Does oral treatment with ACE inhibitors or $\mathrm{AT}_{1}$ receptor blockers improve adipose tissue blood flow and/or capillarisation? If so, are these changes in ATBF related to improvements in endothelial function?

- What is the physiological relevance of the Ang II-induced vasoconstriction in skeletal muscle with regard to glucose uptake in this tissue?

- Is there potential for dietary modification of tissue blood flow?

\section{References}

1. Reaven GM. Banting lecture 1988. Role of insulin resistance in human disease. Diabetes 1988;37(12):1595-607.

2. Engeli S, Bohnke J, Gorzelniak K, Janke J, Schling P, Bader M, ct al. Weight Loss and the Renin-Angiotensin-Aldosterone System. Hypertension 2005.

3. Cooper R, Forrester T, Ogunbiyi O, Muffinda J. Angiotensinogen levels and obesity in four black populations. ICSHIB Investigators. J Hypettens 1998;16(5):571-5.

4. Cooper R, McFarlane-Anderson N, Bennett FI, Wilks R, Puras A, Tewksbury D, et al. ACE, angiotensinogen and obesity: a potential pathway leading to hypertension. J Hum Hypertens 1997;11(2):107-11.

5. Umemura S, Nyui N, Tamura K, Hibi K, Yamaguchi S, Nakamaru M, et al. Plasma angiotensinogen concentrations in obese patients. Am J Hypertens 1997;10(6):629-33. 
6. Bloem LJ, Manatunga AK, Tewksbury DA, Pratt JH. The serum angiotensinogen concentration and variants of the angiotensinogen gene in white and black children. J Clin Invest 1995;95(3):948-53.

7. Licata G, Scaglione R, Ganguzza A, Corrao S, Donatelli M, Partinello G, et al. Central obesity and hypertension. Relationship between fasting serum insulin, plasma renin activity, and diastolic blood pressure in young obese subjects. Am J Hypertens 1994;7(4 $\mathrm{Pt}_{t}$ 1):314-20.

8. Egan BM, Stepniakowski K, Goodfriend TL. Renin and aldosterone are higher and the hyperinsulinemic effect of salt restriction greater in subjects with risk factors clustering. Am J Hypertens 1994;7(10 Pt 1):886-93.

9. Kershaw EE, Flier JS. Adipose tissue as an endocrine organ. J Clin Endocrinol Metab 2004;89(6):2548-56.

10. Schling $\mathrm{P}$, Mallow $\mathrm{H}$, Trindl A, Loffler $\mathrm{G}$. Evidence for a local renin angiotensin system in primary cultured human preadipocytes. Int J Obes Relat Metab Disord 1999;23(4):336-41.

11. Karlsson C, Lindell K, Ottosson M, Sjostrom L, Carlsson B, Carlsson LM. Human adipose tissue expresses angiotensinogen and enzymes required for its conversion to angiotensin II. $\mathrm{J}$ Clin Endocrinol Metab 1998;83(11):3925-9.

12. Jonsson JR, Game PA, Head RJ, Frewin DB. The expression and localisation of the angiotensin-converting enzyme mRNA in human adipose tissue. Blood Press 1994;3(1-2):72-5.

13. Massiera F, Bloch-Faure M, Ceiler D, Murakami K, Fukamizu A, Gasc JM, et al. Adipose angiotensinogen is involved in adipose tissue growth and blood pressure regulation. Faseb J 2001;15(14):2727-9.

14. Hollenberg NK, Fisher ND, Price DA. Pathways for angiotensin II generation in intact human tissue: evidence from comparative phatmacological interruption of the renin system. Hypertension 1998;32(3):387-92.

15. Riordan JF. Angiotensin II: biosynthesis, molecular tecognition, and signal transduction. Cell Mol Neurobiol 1995;15(6):637-51.

16. Phillips MI, Speakman EA, Kimura B. Levels of angiotensin and molecular biology of the tissue renin angiotensin systems. Regul Pept 1993;43(1-2):1-20.

17. Chai SY, Zhuo J, Mendelsohn FA. Localization of components of the renin-angiotensin system and site of action of inhibitors. Arzneimittelforschung 1993;43(2A):214-21.

18. Dostal DE, Rothblum KN, Chernin MI, Cooper GR, Baker KM. Intracardiac detection of angiotensinogen and renin: a localized renin- angiotensin system in neonatal rat heart. Am J Physiol 1992;263(4 Pt 1):C838-50.

19. Mulrow PJ. Adrenal renin: regulation and function. Front Neuroendocrinol 1992;13(1):47-60.

20. Dzau VJ, Ellison KE, Brody T, Ingelfinger J, Pratt RE. A comparative study of the distributions of renin and angiotensinogen messenger ribonucleic acids in rat and mouse tissues. Endocrinology 1987;120(6):2334-8.

21. Murakami E, Eggena P, Barrett JD, Sambhi MP. Heterogeneity of renin substrate released from hepatocytes and in brain extracts. Life Sci 1984;34(4):385-92.

22. Jones A, Woods DR. Skeletal muscle RAS and exercise performance. Int J Biochem Cell Biol 2003;35(6):855-66.

23. Schling $P$, Schafer $T$. Human adipose tissue cells keep tight control on the angiotensin II levels in their vicinity. J Biol Chem 2002;277(50):48066-75.

24. Taddei S, Virdis A, Mattei P, Favilla S, Salvetti A. Angiotensin II and sympathetic activity in sodium-restricted essential hypertension. Hypertension 1995;25(4 Pt 1):595-601.

25. Taddei S, Salvetti A. Vascular tissue renin-angiotensin system in hypertensive humans. J Hypertens Suppl 1992;10(7):S165-72.

26. Harte A, McTernan P, Chetty R, Coppack S, Katz J, Smith S, et al. Insulin-mediated upregulation of the renin angiotensin system in human subcutaneous adipocytes is reduced by rosiglitazone. Circulation 2005;111(15):1954-61.

27. Schalekamp MA, Derkx FH, van den Meiracker AH. Renin inhibitors, angiotensin converting enzyme inhibitors and angiotensin II receptor antagonists: relationships between blood pressure responses and effects on the renin-angiotensin system. J Hypertens Suppl 1992;10(7):S157-64.

28. Chai W, Danser AH. Is angiotensin II made inside or outside of the cell? Curr Hypertens Rep 2005;7(2):124-7. 
29. van Harmelen V, Elizalde M, Ariapart P, Bergstedt-Lindqvist S, Reynisdottir S, Hoffstedt J, et al. The association of human adipose angiotensinogen gene expression with abdominal fat distribution in obesity. Int J Obes Relat Metab Disord 2000;24(6):673-8.

30. Giacchetti G, Faloia E, Sardu C, Camilloni MA, Mariniello B, Gatti C, et al. Gene expression of angiotensinogen in adipose tissue of obese patients. Int J Obes Relat Metab Disord 2000;24:S142-3.

31. Abate N, Garg $A$, Peshock RM, Stray-Gundersen J, Grundy SM. Relationships of generalized and regional adiposity to insulin sensitivity in men. J Clin Invest 1995;96(1):88-98.

32. Nielsen S, Guo Z, Johnson CM, Hensrud DD, Jensen MD. Splanchnic lipolysis in human obesity. J Clin Invest 2004;113(11):1582-8.

33. Hsueh W $A$, Goldstone R, Carlson EJ, Horton R. Evidence that the beta-adrenergic system and prostaglandins stimulate renin release through different mechanisms. I Clin Endocrinol Metab 1985;61(3):399-403.

34. Pettinger WA, Mitchell HC. Renin release, saralasin and the vasodilator-beta-blocker drug interaction in man. N Engl J Med 1975;292(23):1214-7.

35. Ramsay DJ. Beta-adrenergic thirst and its relation to the renin-angiotensin system. Fed Proc 1978;37(13):2689-93.

36. Sinaiko AR. Influence of adrenergic nervous and prostaglandin systems on hydralazineinduced renin release. Life Sci 1983;33(23):2269-75.

37. Ueda H. Renin and nervous system. Jpn Heart J 1976;17(4):521-6.

38. Zayas VM, Blumenfeld JD, Bading B, McDonald M, James GD, Lin YF, et al. Adrenergic regulation of renin secretion and renal hemodynamics during deliberate hypotension in humans. Am J Physiol 1993;265(5 Pt 2):F686-92.

39. Nakamaru M, Jackson EK, Inagami $T$. Role of vascular angiotensin II released by betaadrenergic stimulation in rats. J Cardiovasc Pharmacol 1986;8(Suppl 10):S1-5.

40. Bulow J, Astrup A, Christensen NJ, Kastrup J. Blood flow in skin, subcutaneous adipose tissue and skeletal muscle in the forearm of normal man during an oral glucose load. Acta Physiol Scand 1987;130(4):657-61.

41. Coppack SW, Evans RD, Fisher RM, Frayn KN, Gibbons GF, Humphreys SM, et al. Adipose tissue metabolism in obesity: lipase action in vivo before and after a mixed meal. Metabolism 1992;41(3):264-72.

42. Evans K, Clark ML, Frayn KN. Effects of an oral and intravenous fat load on adipose tissue and forearm lipid metabolism. Am J Physiol 1999;276(2 Pt 1):E241-8.

43. Frayn KN, Karpe F, Fielding BA, Macdonald IA, Coppack SW. Integrative physiology of human adipose tissue. Int J Obes Relat Metab Disord 2003;27(8):875-88.

44. Jansson PA, Latsson A, Lonnroth PN. Relationship between blood pressure, metabolic variables and blood flow in obese subjects with or without non-insulin-dependent diabetes mellitus. Eur J Clin Invest 1998;28(10):813-8.

45. Summers LK, Samra JS, Humphreys SM, Morris RJ, Frayn KN. Subcutaneous abdominal adipose tissue blood flow: variation within and between subjects and relationship to obesity. Clin Sci (Lond) 1996;91(6):679-83.

46. Blaak EE, van Baak MA, Kemerink GJ, Pakbiers MT, Heidendal GA, Saris WH. Betaadrenergic stimulation and abdominal subcutaneous fat blood flow in lean, obese, and reducedobese subjects. Metabolism 1995;44(2):183-7.

47. Karpe F, Fielding BA, Ilic V, Macdonald IA, Summers LK, Frayn KN. Impaired postprandial adipose tissue blood flow response is related to aspects of insulin sensitivity. Diabetes 2002;51(8):2467-73.

48. Samra JS, Simpson EJ, Clark ML, Forster CD, Humphreys SM, Macdonald IA, et al. Effects of epinephrine infusion on adipose tissue: interactions between blood flow and lipid metabolism. Am J Physiol 1996;271(5 Pt 1):E834-9.

49. Ardilouze JL, Fielding BA, Currie JM, Frayn KN, Karpe F. Nitric oxide and beta-adrenergic stimulation are major regulators of preprandial and postprandial subcutaneous adipose tissue blood flow in humans. Circulation 2004;109(1):47-52.

50. Timmermans PB, Wong PC, Chiu AT, Herblin WF, Benfield P, Carini DJ, et al. Angiotensin II receptors and angiotensin II receptor antagonists. Pharmacol Rev 1993;45(2):205-51. 
51. Samra JS, Frayn KN, Giddings JA, Clark ML, Macdonald IA. Modification and validation of a commercially available portable detector for measurement of adipose tissue blood flow. Clin Physiol 1995;15(3):241-8.

52. Hsueh WA, Quinones MJ. Role of endothelial dysfunction in insulin resistance. Am J Cardiol 2003;92(4A):10J-17J.

53. Tooke JE, Hannemann MM. Adverse endothelial function and the insulin resistance syndrome. J Intern Med 2000;247(4):425-31.

54. de Gasparo M. Angiotensin II and nitric oxide interaction. Heart Fail Rev 2002;7(4):347-58.

55. Engfeldt P, Linde B. Subcutaneous adipose tissue blood flow in the abdominal and femoral regions in obese women: effect of fasting. Int J Obes Relat Metab Disord 1992;16(11):875-9.

56. Jansson PA, Larsson A, Smith $U$, Lonnroth P. Glycerol production in subcutaneous adipose tissue in lean and obese humans. J Clin Invest 1992;89(5):1610-7.

57. Simonsen L, Bulow J, Astrup A, Madsen J, Christensen NJ. Diet-induced changes in subcutaneous adipose tissue blood flow in man: effect of beta-adrenoceptor inhibition. Acta Physiol Scand 1990;139(2):341-6.

58. DeFronzo RA, Jacot E, Jequier E, Maeder E, Wahren J, Felber JP. The effect of insulin on the disposal of intravenous glucose. Results from indirect calorimetry and hepatic and femoral venous catheterization. Diabetes 1981;30(12):1000-7.

59. Baron AD, Clark MG. Role of blood flow in the regulation of muscle glucose uptake. Annu Rev Nutr 1997;17:487-99.

60. Vincent MA, Clerk LH, Lindner JR, Klibanov AL, Clark MG, Rattigan S, et al. Mictovascular recruitment is an early insulin effect that regulates skeletal muscle glucose uptake in vivo. Diabetes 2004;53(6):1418-23.

61. Clark MG, Wallis MG, Barrett EJ, Vincent MA, Richards SM, Clerk LH, et al. Blood flow and muscle metabolism: a focus on insulin action. Am J Physiol Endocrinol Metab 2003;284(2): E241-58.

62. de Jongh RT, Serne EH, RG IJ, de Vries G, Stehouwer CD. Impaired microvascular function in obesity: implications for obesity-associated microangiopathy, hypertension, and insulin resistance. Circulation 2004;109(21):2529-35.

63. Wallis MG, Wheatley CM, Rattigan S, Barrett EJ, Clark AD, Clark MG. Insulin-mediated hemodynamic changes are impaired in muscle of Zucker obese rats. Diabetes 2002;51(12):3492-8.

64. Massiera F, Seydoux J, Geloen A, Quignard-Boulange A, Turban S, Saint-Marc P, et al. Angiotensinogen-deficient mice exhibit impairment of diet-induced weight gain with alteration in adipose tissue development and increased locomotor activity. Endocrinology 2001;142(12):5220-5.

65. Jones BH, Standridge MK, Moustaid N. Angiotensin II increases lipogenesis in 3T3-L1 and human adipose cells. Endocrinology 1997;138(4):1512-9.

66. Boschmann M, Ringel J, Klaus S, Sharma AM. Metabolic and hemodynamic response of adipose tissue to angiotensin II. Obes Res 2001;9(8):486-91.

67. Boschmann M, Jordan J, Schmidt S, Adams F, Luft FC, Klaus S. Gender-Specific Response to Interstitial Angiotensin II in Human White Adipose Tissue. Horm Metab Res 2002;34(1112):726-30.

68. Boschmann M, Jordan J, Adams F, Christensen NJ, Tank J, Franke G, et al. Tissue-specific response to interstitial angiotensin II in humans. Hypertension 2003;41(1):37-41.

69. Arner P, Bolinder J, Ostman J. Glucose stimulation of the antilipolytic effect of insulin in humans. Science 1983;220(4601):1057-9.

70. Stevens J, Atkinson RL, Pohl SL. Insulin-induced insulin resistance of lipolysis in human adipocytes in organ culture. J Clin Endocrinol Metab 1980;51(4):921-4.

71. Janke J, Engeli S, Gorzelniak K, Luft FC, Sharma AM. Mature adipocytes inhibit in vitro differentiation of human preadipocytes via angiotensin type 1 receptors. Diabetes 2002;51(6):1699-707.

72. Yusuf S, Sleight P, Pogue J, Bosch J, Davies R, Dagenais G. Effects of an angiotensinconverting-enzyme inhibitor, ramipril, on cardiovascular events in high-risk patients. The Heart Outcomes Prevention Evaluation Study Investigators. N Engl J Med 2000;342(3):14553. 
73. Hansson L, Lindholm LH, Niskanen L, Lanke J, Hedner T, Niklason A, et al. Effect of angiotensin-converting-enzyme inhibition compared with conventional therapy on cardiovascular morbidity and mortality in hypertension: the Captopril Prevention Project (CAPPP) randomised trial. Lancet 1999;353(9153):611-6.

74. Torlone E, Britta M, Rambotti AM, Perriello G, Santeusanio F, Brunetti P, et al. Improved insulin action and glycemic control after long-term angiotensin-converting enzyme inhibition in subjects with arterial hypertension and type II diabetes. Diabetes Care 1993;16(10):1347-55.

75. Dahlof B, Devereux RB, Kjeldsen SE, Julius S, Beevers G, de Faire U, et al. Cardiovascular morbidity and mortality in the Losartan Intervention For Endpoint reduction in hypertension study (LIFE): a randomised trial against atenolol. Lancet 2002;359(9311):995-1003.

76. Jandeleit-Dahm KA, Tikellis C, Reid CM, Johnston CI, Cooper ME. Why blockade of the renin-angiotensin system reduces the incidence of new-onset diabetes. J Hypertens 2005;23(3):463-73.

77. Wiggam MI, Hunter SJ, Atkinson AB, Ennis CN, Henry JS, Browne JN, et al. Captopril does not improve insulin action in essential hypertension: a double-blind placebo-controlled study. J Hypertens 1998;16(11):1651-7.

78. New JP, Bilous RW, Walker M. Insulin sensitivity in hypertensive Type 2 diabetic patients after 1 and 19 days' treatment with trandolapril. Diabet Med 2000;17(2):134-40.

79. Petrie JR, Morris AD, Ueda S, Small M, Donnelly R, Connell JM, et al. Trandolapril does not improve insulin sensitivity in patients with hypertension and type 2 diabetes: a double-blind, placebo-controlled crossover trial. J Clin Endocrinol Metab 2000;85(5):1882-9.

80. Goossens GH, Blaak EE, Saris WH, Van Baak MA. Angiotensin II-induced effects on adipose and skeletal muscle tissue blood flow and lipolysis in normal-weight and obese subjects. J Clin Endocrinol Metab 2004;89(6):2690-6.

81. Hermann TS, Li W, Dominguez H, Ihlemann N, Rask-Madsen C, Major-Pedersen A, et al. Quinapril Treatment Increases Insulin-stimulated Endothelial Function and Adiponectin Gene Expression in Patients with Type 2 Diabetes. J Clin Endocrinol Metab 2006;91(3):1001-8.

82. Galletti F, Strazzullo P, Capaldo B, Carretta R, Fabris F, Ferrara LA, et al. Controlled study of the effect of angiotensin converting enzyme inhibition versus calcium-entry blockade on insulin sensitivity in overweight hypertensive patients: Trandolapril Italian Study (TRIS). J Hypertens 1999;17(3):439-45.

83. Santoro D, Natali A, Palombo C, Brandi LS, Piatti M, Ghione S, et al. Effects of chronic angiotensin converting enzyme inhibition on glucose tolerance and insulin sensitivity in essential hypertension. Hypertension 1992;20(2):181-91.

84. Matthews DR, Hosker JP, Rudenski AS, Naylor BA, Treacher DF, Turner RC. Homeostasis model assessment: insulin resistance and beta-cell function from fasting plasma glucose and insulin concentrations in man. Diabetologia 1985;28(7):412-9.

85. Sharma AM, Janke J, Gorzelniak K, Engeli S, Luft FC. Angiotensin blockade prevents type 2 diabetes by formation of fat cells. Hypertension 2002;40(5):609-11.

86. Jacob S, Machann J, Rett K, Brechtel K, Volk A, Renn W, et al. Association of increased intramyocellular lipid content with insulin resistance in lean nondiabetic offspring of type 2 diabetic subjects. Diabetes 1999;48(5):1113-9.

87. Forouhi NG, Jenkinson G, Thomas EL, Mullick S, Mierisova S, Bhonsle U, et al. Relation of triglyceride stores in skeletal muscle cells to central obesity and insulin sensitivity in European and South Asian men. Diabetologia 1999;42(8):932-5.

88. Pan DA, Lillioja S, Kriketos AD, Milner MR, Baur LA, Bogardus C, et al. Skeletal muscle triglyceride levels are inversely telated to insulin action. Diabetes 1997;46(6):983-8.

89. Koyama K, Chen G, Lee Y, Unger RH. Tissue triglycerides, insulin resistance, and insulin production: implications for hyperinsulinemia of obesity. Am J Physiol 1997;273(4 Pt 1):E70813.

90. Bjorntorp P. Liver triglycerides and metabolism. Int J Obes Relat Metab Disord 1995;19(12):839-40.

91. Bancrii MA, Buckley MC, Chaiken RL, Gordon D, Lebovitz HE, Kral JG. Liver fat, serum triglycerides and visceral adipose tissue in insulin-sensitive and insulin-resistant black men with NIDDM. Int J Obes Relat Metab Disord 1995;19(12):846-50. 
92. Wellen KE, Hotamisligil GS. Inflammation, stress, and diabetes. J Clin Invest 2005;115(5):1111-9.

93. Wellen KE, Hotamisligil GS. Obesity-induced inflammatory changes in adipose tissue. J Clin Invest 2003;112(12):1785-8.

94. Hotamisligil GS. Inflammatory pathways and insulin action. Int J Obes Relat Metab Disord 2003;27 Supp1 3:\$53-5.

95. Giacchetri G, Sechi LA, Rilli S, Carey RM. The renin-angiotensin-aldosterone system, glucose metabolism and diabetes. Trends Endocrinol Metab 2005;16(3):120-6.

96. Hattori Y, Akimoto K, Gross SS, Hattori S, Kasai K. Angiotensin-II-induced oxidative stress elicits hypoadiponectinaemia in rats. Diabetologia 2005;48(6):1066-74.

97. Leiter LA, Lewanczuk RZ. Of the renin-angiotensin system and reactive oxygen species: type 2 diabetes and angiotensin II inhibition. Am J Hypertens 2005;18(1):121-8.

98. McFarlane SI, Kumar A, Sowers JR. Mechanisms by which angiotensin-converting enzyme inhibitors prevent diabetes and cardiovascular disease. Am J Cardiol 2003;91(12A):30H-37H.

99. Staessen JA, Wang J, Bianchi G, Birkenhager WH. Essential hypertension. Lancet 2003;361(9369):1629-41.

100. Genest J. Progress in hypertension research: 1900-2000. Hypertension 2001;38(4):E13-8.

101. Regitz-Zagrosek V, Neuss M, Holzmeister J, Warnecke C, Fleck E. Molecular biology of angiotensin receptors and their role in human cardiovascular disease. J Mol Med 1996;74(5):233-51.

102. Dzau VJ. Cell biology and genetics of angiotensin in cardiovascular disease. I Hypertens Suppl 1994;12(4):S3-10.

103. Johnston CI. Biochemistry and pharmacology of the renin-angiotensin system. Drugs 1990;39(Suppl 1):21-31.

104. Reid IA, Morris BJ, Ganong WF. The renin-angiotensin system. Annu Rev Physiol 1978;40:377-410. 


\section{Summary - Samenvatting}




\section{Summary}

Abdominal obesity plays a central role in the metabolic syndrome and is a major risk factor for type 2 diabetes mellitus and cardiovascular disease. Unravelling the underlying mechanisms of obesity and obesity-related metabolic and hemodynamic disorders, such as insulin resistance and hypertension, may increase the rationale for dietary and/or pharmacological strategies to prevent or treat type 2 diabetes and cardiovascular disease.

There is substantial evidence for the involvement of the renin-angiotensin system (RAS) in obesity-related disorders, as extensively reviewed in chapters 1 and 2. Both animal and human studies support the idea that increased RAS activity may lead to insulin resistance and hypertension. With respect to increased RAS activity in obesity, it is tempting to postulate that the RAS in adipose tissue may exert autocrine, paracrine and/or endocrine effects that may contribute to obesityrelated disorders. This thesis describes a variety of studies that investigated local (autocrine/paracrine) and systemic (endocrine) metabolic and hemodynamic effects of the RAS in normal-weight and obese subjects, combining in vivo techniques and in vitro approaches.

In chapter 3, the endocrine function of locally produced angiotensin II (Ang II) in adipose tissue and skeletal muscle was examined in vivo in humans. We demonstrated that there is no net Ang II release across abdominal subcutaneous adipose tissue and the forearm in lean and obese subjects. This suggests that Ang II that is produced by adipocytes and in skeletal muscle acts as an autocrine/paracrine hormone. However, it does not contribute to the circulating Ang II concentration. Furthermore, we found that $\beta$-adrenergic stimulation increased plasma Ang II concentration in obese, but not in lean subjects. Our observations imply that the increased plasma Ang II concentration during $\beta$-adrenergic stimulation in obese subjects is explained by other factors than Ang II release from abdominal subcutaneous adipose tissue and/or the forearm. The release of other RAS components, such as angiotensinogen (AGT) and renin, from adipose tissue may be increased during $\beta$-adrenergic stimulation in obese subjects, which may elevate Ang II generation in the circulation. Alternatively, local Ang II secretion from other tissues than abdominal subcutaneous adipose tissue and the forearm, such as the kidney and liver, may explain this observation.

Ang II is a potent vasoconstrictor and is an important regulator of blood pressure and fluid homeostasis. Therefore, Ang II may exert vasoconstrictive effects in metabolically active tissues, such as adipose tissue and skeletal muscle. In chapter 
4, we showed that local Ang II administration decreases blood flow through adipose tissue and skeletal muscle. These Ang II-induced effects were comparable in normal-weight and obese subjects. The Ang II-induced decrease of adipose tissue and skeletal muscle blood flow may have great impact on metabolism, as blood flow determines the delivery of substrates and hormones to each tissue. A decreased adipose tissue blood flow (ATBF) may reduce triacylglycerol (TAG) clearance by adipose tissue, leading to increased circulating TAG concentrations and an increased delivery of TAG to skeletal muscle, liver and pancreas, which may result in lipid accumulation in these tissues. These events may induce insulin resistance in skeletal muscle and liver, and impair insulin secretion by the pancreas. The decrease in skeletal muscle blood flow evoked by Ang II may affect glucose uptake in this tissue, but this depends on the reduction of blood flow through nutritive vessels. Future research is necessary to examine the effects of the Ang IIinduced vasoconstriction in adipose tissue and skeletal muscle on metabolism.

Based on these findings, we decided to investigate the role of Ang II in ATBF regulation into more detail using the recently developed microinfusion technique, as described in chapter 5. First, we confirmed the findings in chapter 4, showing that Ang II markedly decreases blood flow through abdominal subcutaneous adipose tissue. Secondly, it was demonstrated that circulating Ang II that reaches adipose tissue, rather than locally produced Ang II in adipose tissue, decreases fasting ATBF under physiological conditions. Because Ang II is produced by human adipocytes, these data strongly suggest that locally produced Ang II in adipose tissue acts as an autocrine/paracrine rather than an endocrine hormone, which is in line with our finding that there is no net Ang II release from adipose tissue in humans (chapter 3). Furthermore, Ang II does not appear to be involved in postprandial ATBF regulation, which is in accordance with previous investigations showing that the postprandial enhancement of ATBF is predominantly controlled by the $\beta$-adrenergic system. However, the Ang IIinduced decrease in fasting ATBF may decrease absolute ATBF after a meal in subjects with increased RAS activity. This may reduce TAG clearance and, therefore, contribute to postprandial hyperlipidemia. Finally, we showed that the Ang II-induced decrease in fasting ATBF is predominantly independent of nitric oxide (NO) action, suggesting that the balance between Ang II and NO activity may be an important determinant of the vascular tone and thus ATBF under fasting conditions.

As mentioned earlier, the Ang II-induced decrease in ATBF may reduce TAG clearance by adipose tissue. Furthermote, alterations in tissue blood flow may 
affect lipolysis and thus storage of TAG in adipose tissue. In addition to indirect effects of tissue blood flow on lipolysis, Ang II may exert direct effects on lipolysis. We therefore examined the effects of Ang II on lipolysis in adipose tissue and skeletal muscle in humans. In chapter 4, we demonstrated that Ang II inhibits lipolysis in both tissues in vivo in normal-weight and obese subjects. The antilipolytic effect of Ang II was comparable between groups. To obtain better insight into the dose-response effect of Ang II on lipolysis in adipose tissue, and to assess whether the inhibition of lipolysis was caused by direct effects of Ang II on adipocytes, in vitro lipolysis experiments were initiated, as described in chapter 6 . We demonstrated for the first time that Ang II dose-dependently inhibits lipolysis in abdominal subcutaneous adipocytes in normal-weight and obese subjects (maximum inhibition $~ 20-25 \%$ ). The antilipolytic effect of Ang II was completely abolished by Ang II type 1 ( $\left.\mathrm{AT}_{1}\right)$ receptor blockade, indicating that the Ang IIinduced inhibition of lipolysis is mediated through the $\mathrm{AT}_{1}$ receptor. Thus, these in vitro data are in accordance with our findings in vivo, demonstrating that Ang II inhibits lipolysis in adipose tissue. However, the in vitro findings suggest that a physiological Ang II concentration exerts a tonic suppression of lipolysis in human adipocytes. Therefore, Ang II may not play a prominent role in the physiological regulation of fat cell lipolysis in vivo in humans. These findings, together with the reported inhibitory effect of Ang II on adipocyte differentiation in humans, suggest that Ang II may not be involved in the expansion of fat mass in humans. The Ang II-induced inhibition of lipolysis in skeletal muscle may contribute to lipid accumulation in this tissue, but further research is needed to examine the dose-response effect of Ang II on lipolysis in skeletal muscle.

Long-term clinical trials have demonstrated that blockade of the RAS reduces the incidence of type 2 diabetes mellitus. As described in chapter 7, we performed a double-blind placebo-controlled randomized trial in obese, insulin resistant subjects to examine the effects of short-term angiotensin-converting enzyme (ACE) inhibitor treatment on insulin sensitivity. In addition, several proposed mechanisms that may underlie the beneficial effects of RAS blockade on the development of diabetes were examined. We showed that 2-week ACE inhibitor treatment has no significant effects on whole-body insulin sensitivity, forearm blood flow, glucose uptake across the forearm, whole-body substrate oxidation, and intramuscular TAG content. Therefore, it can be tentatively concluded that short-term RAS blockade has no clinically relevant effects on insulin sensitivity. These findings suggest that the beneficial effects of agents that interfere with the RAS on the development of type 2 diabetes may be explained by long-term effects. 
It has previously been reported that Ang II inhibits adipocyte differentiation and stimulates lipogenesis. These processes, together with the inhibition of fat cell lipolysis by Ang II (chapters 4 and 6), may decrease the buffering capacity for lipid storage in adipose tissue in the long-term, which may result in an excessive influx of TAG and fatty acids to skeletal muscle, liver, and pancreas, leading to insulin resistance and an impaired insulin secretion. Thus, it is tempting to postulate that structural changes in adipose tissue induced by long-term RAS blockade may underlie the reduced incidence of type 2 diabetes observed in several clinical trials.

The RAS has been established as a major regulator of blood pressure and fluid homeostasis. Although the RAS may play an important role in obesity-related hypertension, the notion that interference with a sole pathophysiological mechanism will substantially facilitate prevention or treatment of hypertension is an oversimplification that ignores the heterogeneous nature of this disorder. Chapter 8 clearly shows that the treatment of obesity-related hypertension is ambiguous, and highlights the role of RAS blockade in the treatment of hypertension in obese individuals. Prospective studies in obese patients are necessary before deciding on the most suitable antihypertensive treatment in these individuals.

In summary, from the series of studies described in this thesis the main conclusions are that:

1. locally produced Ang II in adipose tissue and skeletal muscle does not play an endocrine role in humans, indicating that Ang II that is locally produced in these tissues exerts autocrine/paracrine effects.

2. Ang II inhibits lipolysis in adipose tissue and skeletal muscle in normalweight and obese subjects. Because physiological Ang II concentrations evoked near-maximal inhibition of fat cell lipolysis, Ang II may not play a prominent role in the regulation of lipolysis in adipose tissue in humans. The Ang II-induced inhibition of lipolysis in skeletal muscle may contribute to lipid accumulation in this tissue.

3. Ang II is a major regulator of fasting adipose tissue and skeletal muscle blood flow in normal-weight and obese humans. Circulating Ang II rather than locally produced Ang II in adipose tissue is responsible for the Ang IIinduced decrease in adipose tissue blood flow. The effects of Ang II on blood flow through adipose tissue were predominantly independent of NO action. Ang II appears to have no major effect on the postprandial enhancement of adipose tissue blood flow. 
4. short-term RAS blockade has no significant effects on insulin sensitivity, forearm blood flow, glucose uptake in skeletal muscle, whole-body substrate oxidation, and IMTG content in obese, insulin resistant subjects. Therefore, the reduced incidence of type 2 diabetes after long-term RAS blockade appears to be explained by long-term effects that could affect insulin sensitivity and/or insulin secretion. 


\section{Samenvatting}

Abdominale obesitas speelt een centrale rol in het metabool syndroom en is een belangrijke risicofactor voor type 2 diabetes mellitus en hart- en vaatziekten. Inzicht in de mechanismen die ten grondslag liggen aan het ontstaan van obesitas en obesitas-gerelateerde metabole en hemodynamische verstoringen, zoals insulineresistentie en hypertensie, zou kunnen leiden tot beter onderbouwde voedings- en/of farmacologische interventies om type 2 diabetes en hart- en vaatziekten te voorkomen of te behandelen.

Er is aanzienlijk bewijs dat het renine-angiotensine systeem (RAS) bctrokken is bij het ontstaan van obesitas-gerelateerde verstoringen, zoals uitgebreid beschreven in hoofdstukken 1 en 2 . Onderzoeken bij zowel dieren als mensen ondersteunen het concept dat een verhoogde RAS activiteit zou kunnen leiden tot insulineresistentie en hypertensie. Vanwege de verhoogde RAS activiteit in obesen kan gesuggereerd worden dat het RAS in vetweefsel lokale en/of systemische effecten heeft die bij kunnen dragen aan obesitas-gerelateerde verstoringen. Dit proefschrift beschrijft een reeks van studies waarbij de lokale (autocriene/paracriene) en systemische (endocriene) metabole en hemodynamische effecten van het RAS zijn onderzocht in mannen met normaal lichaamsgewicht en obesen. Hierbij is gebruik gemaakt van zowel in vivo als in vitro benaderingen.

In hoofdstuk 3 is de endocriene functie van lokaal geproduceerd angiotensine II (Ang II) in vetweefsel en de skeletspier onderzocht in vivo bij mensen. We tonen aan dat er geen netto Ang II secretie is door abdominaal subcutaan vetweefsel en de skeletspier in slanke en obese proefpersonen. Dit suggereert dat Ang II dat geproduceerd wordt door adipocyten en in de skeletspier functioneert als een autocrien/paracrien hormoon. Lokaal geproduceerd Ang II in vetweefsel en de skeletspier draagt dus niet bij aan de Ang II concentratie in de circulatie. Daarnaast blijkt dat $\beta$-adrenerge stimulatie de circulerende Ang II concentratie verhoogt in obese, maar niet in slanke proefpersonen. Onze bevindingen impliceren dat de verhoogde plasma Ang II concentratie tijdens $\beta$-adrenerge stimulatie in obesen verklaard wordt door andere factoren dan. Ang II sectetie door abdominaal subcutaan vetweefsel en/of de onderarm. De secretie van andere RAS componenten, zoals angiotensinogeen (AGT) en renine, door vetweefsel kan verhoogd zijn tijdens $\beta$-adrenerge stimulatie in obesen, wat tot een verhoogde Ang II productie in de circulatie zou kunnen leiden. Tevens zou lokale Ang II secretic 
door andere weefsels dan abdominaal subcutaan vetweefsel en de onderarm, zoals de nieren en lever, deze bevinding kunnen verklaren.

Ang II is een vasoconstrictor en een belangrijke regulator van de bloeddruk en vochtbalans. Ang II zou daarom kunnen leiden tot vasoconstrictie in metabool actieve weefsels, zoals vetweefsel en de skeletspier. Uit hoofdstuk 4 blijkt dat lokale toediening van Ang II de doorbloeding van vetweefsel en de skeletspier verlaagt. Deze effecten zijn vergelijkbaar in mensen met normaal gewicht en obesitas. De Ang II-geïnduceerde verlaging van de doorbloeding van vetweefsel en de skeletspier heeft mogelijk een belangrijke invloed op de stofwisseling, omdat de doorbloeding de aanvoer van substraten en hormonen naar verschillende weefsels bepaalt. Een verlaagde vetweefseldoorbloeding kan leiden tot een verminderde triacylglycerol (TAG) klaring door vetweefsel, hetgeen resulteert in verhoogde circulerende TAG spiegels en een verhoogde aanvoer van TAG naar de skeletspier, lever en pancreas. Dit resulteert in een verhoogde vetopslag in deze organen, met insulineresistentie in de skeletspier en lever en een verminderde secretie van insuline door de pancreas tot gevolg. De Ang II-geïnduceerde verlaging van de skeletspierdoorbloeding kan de glucose opname in dit weefsel beinvloeden, maar dit is vooral afhankelijk van de verminderde doorbloeding van de bloedvaten die de aanvoer van substraat reguleren. Verder onderzoek is noodzakelijk om de effecten van de Ang II-geïnduceerde vasoconstrictie in vetweefsel en de skeletspier op het metabolisme te onderzoeken.

Op basis van deze bevindingen besloten we de rol van Ang II in de regulatie van de vetweefseldoorbloeding in meer detail te onderzoeken met behulp van de recent ontwikkelde microinfusie techniek, zoals beschreven is in hoofdstuk 5 . Ten eerste worden de resultaten uit hoofdstuk 4 bevestigd door aan te tonen dat Ang II de vetweefseldoorbloeding aanzienlijk verlaagt. Ten tweede blijkt dat circulerend Ang II dat het vetweefsel bereikt, en niet Ang II dat lokaal geproduceerd wordt in vetweefsel, de vetweefseldoorbloeding verlaagt onder gevaste omstandigheden. Omdat Ang II geproduceerd wordt door humane adipocyten, suggereren deze resultaten dat lokaal geproduceerd Ang II in vetweefsel een autocrien/paracrien hormoon is dat geen endocriene functie heeft. Dit is in overeenstemming met onze bevinding dat er geen netto Ang II secretie is door vetweefsel bij mensen (hoofdstuk 3). Daarnaast lijkt Ang II niet betrokken te zijn bij de postprandiale regulatie van de vetweefseldoorbloeding, hetgeen in overeenstemming is met eerdere onderzoeken waaruit blijkt dat de postprandiale verhoging van de vetweefseldoorbloeding voornamelijk onder controle staat van het $\beta$-adrenerge systeem. De Ang II-geinduceerde verlaging van de vetweefseldoorbloeding onder 
gevaste omstandigheden kan echter de absolute vetweefseldoorbloeding na een maaltijd verlagen bij personen met een verhoogde RAS activiteit. Dit kan de klaring van TAG verminderen en hierdoor bijdragen aan postprandiale hyperlipidemie. Tenslotte laten we zien dat de Ang II-geinduceerde verlaging van de vetweefseldoorbloeding voornamelijk onafhankelijk is van de werking van stikstof oxide (NO). Dit suggereert dat de balans tussen Ang II en NO activiteit een belangrijke determinant zou kunnen zijn van de tonus van de bloedvaten en dus de vetweefseldoorbloeding onder gevaste omstandigheden.

Zoals eerder genoemd kan de Ang II-geïnduceerde verlaging van de vetweefseldoorbloeding leiden tot een verminderde TAG klaring door vetweefsel. Daarnaast kunnen veranderingen in vetweefseldoorbloeding de lipolyse en dus de opslag van TAG beïnloeden. Naast indirecte effecten van weefseldoorbloeding op de lipolyse kan Ang II directe effecten hebben op de lipolyse. Daatom hebben we de effecten van Ang II op de lipolyse in vetweefsel en de skeletspier onderzocht bij mensen. Uit hoofdstuk 4 blijkt dat Ang II de lipolyse remt in beide weefsels in vivo bij mensen met normaal gewicht en obesitas. De antilipolytische effecten van Ang II zijn vergelijkbaar tussen beide groepen. Om beter inzicht te verkrijgen in het dosis-respons effect van Ang II op de lipolyse in vetweefsel en om vast te stellen of de remming van de lipolyse veroorzaakt wordt door directe effecten van Ang II op de vetcel hebben we in vitro lipolyse experimenten uitgevoerd, zoals beschreven staat in hoofdstuk 6. We tonen voor het eerst aan dat Ang II de lipolyse dosis-afhankelijk temt in adipocyten afkomstig van abdominaal subcutaan vetweefsel van mensen met normaal gewicht en obesitas (maximale remming $\sim 20-25 \%$ ). De antilipolytische effecten van Ang II worden volledig voorkomen door Ang II type $1\left(\mathrm{AT}_{1}\right)$ receptor blokkade. Dit duidt erop dat de Ang II-geïnduceerde remming van de lipolyse gemedieerd wordt via de $\mathrm{AT}_{1}$ receptor. Deze in vitro data zijn in overeenstemming met onze in vivo resultaten die laten zien dat Ang II de lipolyse in vetweefsel remt. De in vitro resultaten suggereren echter dat een fysiologische Ang II concentratie een tonische remming van de lipolyse veroorzaakt in humane adipocyten. Deze bevindingen, in combinatie met het gerapporteerde remmend effect van Ang II op vetceldifferentiatie in mensen, suggereren dat Ang II niet betrokken is bij de toename van vetweefsel in mensen. De Ang II-geinduceerde remming van de lipolyse in de skeletspier kan bijdragen aan vetaccumulatie in dit weefsel, maar verder onderzoek naar het dosis-respons effect van Ang II op de lipolyse in de skeletspier is nodig. 
Lange termijn klinische studies hebben aangetoond dat blokkade van het RAS de incidentie van type 2 diabetes mellitus vermindert. Zoals beschreven staat in hoofdstuk 7 hebben we een dubbel-blind placebo-gecontroleerd gerandomiseerd onderzoek uitgevoerd bij obese insulineresistente mensen om de effecten van korte termijn behandeling met een medicijn dat de vorming van Ang II remt (ACE remmer) op de insulinegevoeligheid te onderzoeken. Tevens hebben we in dit onderzoek verschillende mechanismen onderzocht die ten grondslag kunnen liggen aan de gunstige effecten van RAS blokkade op de ontwikkeling van diabetes. We laten zien dat behandeling met een ACE remmer gedurende 2 weken geen significante effecten heeft op de insulinegevoeligheid, de doorbloeding van de onderarm, glucose opname in de onderarm, substraat oxidatie op lichaamsniveau en de hoeveelheid vet dat opgeslagen is in de skeletspier. Daarom kan geconcludeerd worden dat korte termijn RAS blokkade geen klinisch relevante effecten heeft op de insulinegevoeligheid. Deze resultaten suggereren dat de gunstige effecten van RAS blokkade op de ontwikkeling van type 2 diabetes verklaard kunnen worden door lange termijn effecten. Het is eerder aangetoond dat Ang II de vetceldifferentiatie remt en de lipogenese stimuleert. Deze processen kunnen in combinatie met de remming van de lipolyse in adipocyten (hoofdstukken 4 en 6) op de lange termijn de buffercapaciteit voor de opslag van vetten in vetweefsel verlagen. Dit kan leiden tot een verhoogd aanbod van TAG en vrije vetzuren aan de skeletspier, lever en pancreas, met insulineresistentie en een verminderde insuline secretie tot gevolg. Structurele veranderingen in vetweefsel veroorzaakt door lange termijn RAS blokkade kunnen dus ten grondslag liggen aan de verminderde incidentie van type 2 diabetes die in verschillende klinische onderzoeken is aangetoond.

Het RAS is een belangrijke regulator van de bloeddruk en vochtbalans. Hoewel het RAS een belangrijke rol speelt bij obesitas-gerelateerde hypertensie is de opvatting dat blokkade van een enkel pathofysiologisch mechanisme hypertensie kan voorkomen of de behandeling van hypertensie kan verbeteren te simplistisch. Hierbij wordt geen rekening gehouden met de heterogene aard van hypertensie. Een goed voorbeeld hiervan wordt gegeven in hoofdstuk 8 , waarin duidelijk naar voren komt dat de behandeling van obesitas-gerelateerde hypertensie helaas niet eenvoudig is. Tevens wordt in dit hoofdstuk de rol die RAS blokkade speelt in de behandeling van hypertensie bij obesen benadrukt. Prospectieve onderzoeken in patiënten met obesitas zijn noodzakelijk voordat besloten kan worden wat de meest geschikte behandeling van hypertensie is in deze personen. 
Samenvattend, de belangrijkste conclusies die getrokken kunnen worden uit de reeks van studies die beschreven staan in dit proefschrift zijn:

1. lokaal geproduceerd Ang II in vetweefsel en de skeletspier speelt geen endocriene rol in mensen, hetgeen suggereert dat Ang II dat lokaal geproduceerd wordt in deze weefsels autocriene/paracriene effecten heeft.

2. Ang II remt de lipolyse in vetweefsel en de skeletspier bij mensen met normaal gewicht en obesitas. Aangezien fysiologische Ang II concentraties de lipolyse in vetcellen bijna maximaal onderdrukken, lijkt Ang II geen belangrijke rol te spelen in de regulatie van de lipolyse in vetweefsel bij mensen. De Ang II-geïnduceerde remming van de lipolyse in de skeletspier kan bijdragen aan vetaccumulatie in dit weefsel.

3. Ang II is een belangrijke regulator van de doorbloeding van vetweefsel en de skeletspier bij mensen met normaal gewicht en obesitas. Circulerend Ang II, maar niet lokaal geproduceerd Ang II in vetweefsel, is verantwoordelijk voor de Ang II-geïnduceerde vetlaging van de vetweefseldoorbloeding. De effecten van Ang II op de doorbloeding van vetweefsel zijn voornamelijk onafhankelijk van de werking van NO. Ang II speelt echter geen belangrijke rol in de regulatie van de vetweefseldoorbloeding na een maaltijd.

4. korte termijn RAS blokkade heeft geen significante effecten op de insulinegevoeligheid, de doorbloeding van de onderarm, glucose opname in de skeletspier, substraat oxidatie op lichaamsnivo en de hoeveelheid vet dat opgeslagen is in de skeletspier bij obese insulineresistente mensen. De verminderde incidentie van type 2 diabetes na lange termijn RAS blokkade kan daarom verklaard worden door lange termijn effecten die de insulinegevoeligheid en/of insulinesecretie beïnvloeden. 


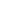


Dankwoord 


\section{Dankwoord}

Hierbij wil ik iedereen die in meer of mindere mate heeft bijgedragen aan de totstandkoming van dit proefschrift bedanken.

Marleen, Ellen, goede begeleiding tijdens een promotietraject is uiteraard van groot belang. Ik wil jullie als co-promotoren vooral ontzettend bedanken voor de vrijheid die jullie me gegeven hebben de afgelopen jaren. Vrijwel vanaf het begin van het promotietraject hebben jullie me mijn gang laten gaan, waardoor ik uiteindelijk een eigen draai heb kunnen geven aan het onderzoek dat beschreven staat in dit proefschrift. Kritisch op de juiste momenten, maat nooit te nadrukkelijk aanwezig. Jullie hebben me veel vertrouwen gegeven en dat heeft zeker bijgedragen aan de prettige samenwerking en dit resultaat. Veel dank daarvoor! Wim, als promotor hield je de voortgang nauwgezet in de gaten en wist je een en ander altijd zo te brengen dat ik vaak extra gemotiveerd je kamer verliet.

Harry Struijker-Boudier, Michaela Diamant, Max Lafontan, Ronald Mensink and Arie Nieuwenhuizen Kruseman, thank you very much for your critical evaluation of this thesis. Fredrik Karpe, I'm honoured that you accepted the invitation to be part of the corona during the public defense of my thesis.

Peter Amer, Louise Dennis, Keith Frayn, Johan Jocken, Fredrik Karpe, Peter de Leeuw, Siobhan McQuaid and Paul Schiffers, thank you for your contributions to the different chapters of this thesis.

Joris, vriend, ex-huisgenoot en mijn paranimf, ik realiseer me dat wij de afgelopen jaren heel wat uren met elkaar doorgebracht hebben buiten werktijd. Ik kan het aantal maaltijden/bitterballen dat we samen genuttigd hebben en het aantal uren op de fiets niet noemen, maar het waren er heel veel. Kortom, vele ontspanningsuurtjes naast het werk. Ik hoojp van harte en ben er zeker van dat we hier de komende tijd mee doorgaan! René, ik kan me altijd helemaal vinden in die geweldige nuchterheid van je! Studiegenoten, collega-promovendi en de komende jaren blijven we collega's: het gaat me nog steeds niet vervelen! Ik ben dan ook erg blij dat ik jullie als mijn paranimfen achter me heb staan binnenkort!

Joost, ook een apart woord van dank voor jou. Ik heb de beginfase van mijn promotietraject bij jou op de kamer mogen doorbrengen en dat zal ik niet snel vergeten! Bijna altijd vrolijk, nooit te beroerd om even te helpen, recht door zee, bedankt!

Tevens wil ik alle proefpersonen bedanken die deel hebben genomen aan de verschillende (soms invasieve en intensieve) onderzoeken. Zonder jullie had ik dit proefschrift nooit kunnen schrijven! 
Anneke en Johan J., ik wil jullie als kamergenoten bedanken voor het aanhoren van mijn verhalen, variërend van reviewers die er in mijn ogen naast zaten tot de 'keuzes in het leven'. De discussies over de 'cultuurkloof die er blijkbaar nog steeds is tussen Belgen en Nederlanders en vele andere zaken heb ik erg gewaardeerd! Anneke en Paula, bedankt voor jullie geweldige inzet als stagiaires bij heel wat lange testdagen!

Jos, Wendy en Joan, bedankt voor jullie ondersteuning bij het analyseren van vele plasmamonsters.

Dank ook aan de overige (oud-)collega's van Humane Biologie voor de prettige werksfeer: Marco, Wouter, Jogchum, Cyriel, Sander, Sandy, Marie-Jeanne, Mandy, Tanja H., Marja, Mirjam, Hasibe, Johan R, Patrick, Hanneke, Niels, Kristof, Freek, Marjolijn, Stefan, Kirsten, Stan, Eefje, Cheryl, Kristel, Neeltje, Manuela, Lydia, Ariënne, Annemie, Petra, Esther K., Gabby, Claudia, Larisa, Ilona, Ronald, Kaatje, Luc, Natalie, Ralph, Marcel, Edwin, Renate, Dorien, Esther P., Ronny, Margriet, Julian, Paul, Astrid, Egbert, Annemiek, Elke T., Elke N., Julia, Ping, Klaas, Loek, Antoine, Martine, Freddy, Tanja A., Guy, Myriam, Pascal, Annemarie, Marieke, Jonathan, Arie, Uriëll, Wendy B., Alie, Andrea en Herman.

Paul Schiffers en Jet Bost, ontzettend bedankt voor jullie geweldige inzet met betrekking tot de Ang II, ACE en AGT bepalingen, totaal ongeveer 25 RIA's en heel wat Cobas bepalingen!

Dear Keith and Fredrik, I cannot thank you enough for the opportunity you have given me to work at your lab. The high-quality research I could participate in, your enthusiasm and the many discussions we have had during my first visit to your lab have led to a substantial increase in my scientific interest. The way you welcomed me when I returned to your lab for a collaborative project last year was absolutely great. I have great respect for you and your work and I look forward to future collaboration. Garry, thank you for the many nice discussions we have had. I really enjoyed working on our 'secret b-vein project' together with Fredrik! I would also like to thank the other members of the Oxford Centre for Diabetes, Endocrinology and Metabolism for making both periods in Oxford unforgettable. Siobhan, Louise, Barbara, Sandy, Jean-Luc, Carine, Richard, Denise, Geoff, Anne, Jenny, Vera, Mo, Elisabetta, Jin-Ichi, Bente, Ulf, Toralph, Leanne, Matt, Alex, Rachel, Jane, Claire, Marjorie and Pauline: thank you very much!

Dennis, Bjorn en Mikel...,'Mathieus'. Ik realiseer me nu dat we bijna 18 jaar lang ieder weekend samen tegen een balletje hebben getrapt. Jullie laten iedere keer weer blijken wat echte vriendschap is. Nu zien jullie eindelijk eens het resultaat van de afgelopen jaren in Maastricht (Wat, dit boekje?'). Dank voor alles! 
Mariska, ik wil jou enorm bedanken voor je steun en de vrijheid die je me hebt gegeven om twee keer naar het buitenland te vertrekken. Dank voor je begrip en de mooie tijd die we samen hebben gehad!

$\mathrm{Pa}$ en ma, jullie staan altijd voor me klaar en hebben me altijd gesteund in de dingen die ik doe. 'Je moet doen wat je leuk vindt'...ik ben blij dat ik kan zeggen dat ik daar goed naar geluisterd heb. Laat duidelijk zijn dat ik enorm trots ben op jullie! Ontzettend bedankt voor alles!

Kim en John, bedankt voor jullie interesse in de voortgang van mijn onderzoek. Kim, een lievere zus kan ik me niet wensen! Ik ben ontzettend trots dat ik sinds kort oom ben! Veel geluk samen met Janneke! 
Curriculum vitae 


\section{Curriculum vitae}

Gijs Goossens was born on June 23rd 1979 in Boxtel, The Netherlands. He completed secondary school at the Jacob Roelandslyceum in Boxtel in 1997. In the same year, he started his study Health Sciences with specialization Movement Sciences at the Faculty of Health Sciences, Maastricht University, The Netherlands, where he graduated in 2002. His master thesis entitled 'Relationship between intramuscular lipids and indicators of glucose tolerance, obesity, maximal aerobic capacity and substrate utilisation' was awarded with the Unilever Research Award 2002 for best master thesis by the Unilever Health Institute.

In 2001, he received a grant from the Dutch Diabetes Research Foundation for a research period at the Oxford Centre for Diabetes, Endocrinology and Metabolism, University of Oxford, Oxford, UK under supervision of Prof. dr. Keith Frayn en Dr. Fredrik Karpe (from October 2001 until April 2002), whete he developed a novel technique to directly assess gluteal adipose tissue function in vivo in humans, combining determinations of arterio-venous differences actoss adipose tissue and blood flow measurements. These techniques were then applied in a cohort of healthy subjects, resulting in a scientific publication.

In January 2002, he started his $\mathrm{PhD}$ at the Department of Human Biology (NUTRIM), Maastricht University, under supervision of Dr. Marleen van Baak, Dr. Ellen Blaak and Prof. dr. Wim Saris, investigating the role of the reninangiotensin system in obesity and obesity-related disorders. In 2005, he received a grant from the Netherlands Organisation for Scientific Research (NWO) to perform a collaborative project with Dr. Fredrik Karpe and Prof. dr. Keith Frayn at the Oxford Centre for Diabetes, Endocrinology and Metabolism (from January until April 2005). Furthermore, he was awarded a travel grant from the International Association for the Study of Obesity (IASO) to attend the $4^{\text {th }}$ IASO Stock Conference in Istanbul, Turkey (March 21-23rd, 2005).

In October 2005, he was awarded the Young Investigator Award for his presentation 'Angiotensin II: a major regulator of subcutaneous adipose tissue blood flow in humans' at the $4^{\text {th }}$ International Symposium on Obesity and Hypertension (ISOH'05) in Berlin, Germany.

In March 2006, he was granted a 'Talent for the Future' scholarship of the Faculty of Health Sciences of Maastricht University to continue his work on the reninangiotensin system and adipose tissue biology at the Department of Human Biology (NUTRIM). 


\section{List of publications}




\section{List of publications}

\section{Full papers}

1. Goossens GH, McQuaid SE, Dennis AL, van Baak MA, Blaak EE, Frayn KN, Saris WHM, Karpe F. Angiotensin II: a major regulator of subcutaneous adipose tissue blood flow in humans. J Physiol 2006;571(2):451-60.

2. Goossens GH, Blaak EE, Arner P, Saris WHM, van Baak MA. Angiotensin II: a hormone that affects lipid metabolism in adipose tissue. Int J Obes Relat Metab Disord 2006 (in press).

3. Goossens GH, Blaak EE, Saris WHM, van Baak MA. Angiotensin II-induced effects on adipose and skeletal muscle tissue blood flow and lipolysis in normal-weight and obese subjects. J Clin Endoctinol Met 2004;89(6):2690-6.

4. Tan GD, Goossens GH, Humphreys SM, Vidal H, Karpe F. Upper and lower body adipose tissue function: a direct comparison of fat mobilization in humans. Obes Res 2004;12(1):114-8.

5. Goossens GH, Blaak EE, van Baak MA. Possible involvement of the adipose tissue renin-angiotensin system in the pathophysiology of obesity and obesityrelated disorders. Obes Rev 2003;4(1):43-55.

6. Goossens GH, Blaak EE, Schiffers PM, Saris WHM, van Baak MA. ACE inhibition and insulin sensitivity in obese insulin resistant subjects: a doubleblind placebo-controlled randomized trial to examine underlying mechanisms. Submitted for publication.

7. Goossens GH, Mensink M, Kooi ME, Saris WH, Blaak EE. Increased IMCL content in the $m$. vastus lateralis is associated with glucose tolerance in subjects with IGT and diabetes: a ${ }^{1}$ H-MRS study. Submitted for publication.

8. Smit E, Wang P, Goossens GH, Kruishoop M, van Baak MA, Blaak EE, Boeckx WD, van der Kallen CJ, van Greevenbroek MM, Feskens EJ, Brouwers MCGJ, Mariman ECM. Pigment epithelium-derived factor, a potent anti-angiogenic factor and newly identified adipokine, is produced by 
adipose tissue and is associated with obesity, hypertension and impaired glucose metabolism in humans. Submitted for publication.

9. Goossens GH, Jocken JWE, Blaak EE, Schiffers PM, Saris WHM, van Baak $\mathrm{MA}$. Angiotensin II release from adipose tissue and the forearm in lean and obese subjects in vivo: effect of $\beta$-adrenergic stimulation. In preparation.

\section{Otber publications}

1. Goossens GH, de Leeuw PW, van Baak MA. Management of obesity-related hypertension: reducing renin-angiotensin system activity. Renin Angiotensin System in Cardiovascular Medicine 2005;1(3):12-13.

2. Goossens GH, Mensink M, Kooi, ME, Saris WHM, Blaak EE. De rol van vetten in de spier bij type 2 diabetes mellitus. Chemisch2Weekblad 2002.

Abstracts

1. Goossens GH, McQuaid SE, Dennis AL, van Baak MA, Blaak EE, Frayn KN, Saris WHM, Karpe F. Angiotensin II: a major regulator of subcutaneous adipose tissue blood flow in humans. Int J Obes Relat Metab Disord 2005;29(3):S3.

2. Goossens GH, Jocken JW, Schiffers PM, Blaak EE, Saris WHM, van Baak MA. The effect of $\beta$-adrenergic stimulation on circulating angiotensin II concentration and angiotensin II release from adipose tissue and the forearm. Int J Obes Relat Metab Disord 2005;29(3):S6.

3. Goossens GH, Blaak EE, Schiffers PM, Saris WHM, van Baak MA. Does short-term ACE inhibitor treatment improve insulin sensitivity and hemodynamics in obese insulin resistant subjects? Int J Obes Relat Metab Disord 2005;29(3):S12.

4. Goossens GH, Jocken JW, Blaak EE, Saris WHM, Schiffers PM, van Baak MA. Angiotensin II release from adipose tissue and the forearm in lean and obese men: effect of beta-adrenergic stimulation. Obes Rev 2005;6(1):75. 
5. Goossens GH, Blaak EE, Saris WHM, van Baak MA. Metabolic en hemodynamic effects of the $\mathrm{ACE}$ inhibitor ramipril in obese insulin resistant subjects. Obes Rev 2005;6(1):68.

6. Jocken JWE, Goossens GH, van Baak MA, Saris WHM, Blaak EE. The effect of beta-adrenergic stimulation on abdominal subcutaneous adipose tissue substrate fluxes in lean and obese men. Obes Rev 2005;6(1):74.

7. Goossens GH, van Baak MA, Saris WHM, Blaak EE. The effect of angiotensin II on abdominal subcutaneous adipose tissue lipolysis in normalweight and obese subjects. Int J Obes Relat Metab Disord 2004;28(1):S83.

8. Goossens GH, Blaak EE, Saris WHM, van Baak MA. Ang II-induced effects on adipose and skeletal muscle tissue blood flow and lipolysis. Int J Obes Relat Metab Disord 2003;27:S26.

9. Goossens GH, Tan GD, Humphreys SM, Vidal H, Karpe F. Upper and lower body adipose tissue function: a direct comparison of fat mobilization. Int J Obes Relat Metab Disord 2003;27(1):S49. 